


\section{MARCIN JURCZAK}

\section{INNOWACJE \\ W TRANSPORCIE \\ PUBLICZNYM}

WYDAWNICTWO UEP

Poznań 2021 


\section{Komitet Redakcyjny}

Barbara Borusiak, Szymon Cyfert, Bazyli Czyżewski, Aleksandra Gaweł (przewodnicząca), Tadeusz Kowalski, Piotr Lis, Krzysztof Malaga, Marzena Remlein, Eliza Szybowicz (sekretarz), Daria Wieczorek

\section{Recenzentka}

Sabina Kauf

Projekt okładki

Boobry Group

Marta Brzóstowicz

Zdjęcie na okładce

Marcin Jurczak

\section{Redakcja i korekta}

Deal

(c) Copyright by Uniwersytet Ekonomiczny w Poznaniu

Poznań 2021

ISBN: 978-83-8211-096-8

e-ISBN: 978-83-8211-097-5

https://doi.org/10.18559/978-83-8211-097-5

\section{(1) (1) $\Theta \Theta$}

Ta książka jest udostępniana na licencji Creative Commons - Uznanie autorstwa-Użycie niekomercyjne-Bez utworów zależnych 4.0 Międzynarodowe

\section{WYDAWNICTWO UNIWERSYTETU EKONOMICZNEGO W POZNANIU}

ul. Powstańców Wielkopolskich 16, 61-895 Poznań

tel. 6185431 54, 618543155

www.wydawnictwo.ue.poznan.pl, e-mail:wydawnictwo@ue.poznan.pl adres do korespondencji: al. Niepodległości 10, 61-875 Poznań

Skład: Wydawnictwo eMPi

Reginaldo Cammarano

Druk: Zakład Graficzny Uniwersytetu Ekonomicznego w Poznaniu ul. Towarowa 53, 61-836 Poznań, tel. 6185438 06, 618543803 


\section{SPIS TREŚCI}

Wstęp. Od Schumpetera do autobusów wodorowych

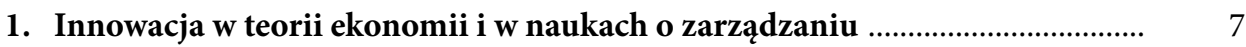

1.1. Model powstania innowacji J.A. Schumpetera .................................................. 7

1.2. Równowaga ogólna a równowaga rynku ......................................................... 13

1.3. Klasyczne i współczesne koncepcje klasyfikacji innowacji ............................. 15

1.4. Miejsce innowacji w naukach o zarządzaniu .................................................... 19

1.5. Uwarunkowania funkcjonowania sektora publicznego ................................. 22

1.6. Uwarunkowania funkcjonowania transportu publicznego a pandemia ....... $\quad 23$

2. Innowacje $w$ zarządzaniu przedsiębiorstwem transportowym ........................... 25

2.1. Źródła innowacji ............................................................................................. 25

2.2. Nowoczesne zarządzanie jako źródło innowacji ............................................. 27

2.3. Integracja środków transportu jako innowacja ............................................... 28

2.4. Innowacja w przedsiębiorstwie a rozpowszechnienie innowacji ................... $\quad 30$

2.5. Innowacje jako katalizator rozwoju przedsiębiorstwa .................................... 32

2.6. Działalność innowacyjna w sektorze usług publicznych ................................. 34

3. Rynek transportu publicznego - specyfika działalności ....................................... 39

3.1. Błędne koło komunikacji miejskiej ................................................................... 40

3.2. Organizacja transportu publicznego: rola i zadania organizatora oraz operatorów .............................................................................................. 42

3.3. Przedsiębiorstwa transportu publicznego - charakterystyka działalności ... $\quad 45$

3.4. Świadczenie usługi i oczekiwania klientów ...................................................... 54

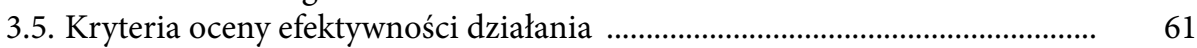

3.6. Innowacje jako katalizator rozwoju rynku ..................................................... 66

4. Innowacje w funkcjonowaniu operatora i organizatora transportu publicznego

4.1. Katalog stosowanych innowacji

4.2. Wybrane innowacje w transporcie publicznym - klasyfikacja ...................... $\quad 69$

4.3. Innowacje dotyczące funkcjonalności pojazdów komunikacji publicznej ... $\quad 71$

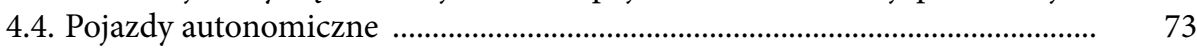

4.5. Napędy alternatywne dla pojazdów komunikacji publicznej ......................... $\quad 80$

4.6. Systemy informatyki i automatyki dla operatora i organizatora transportu . $\quad 96$

4.7. Systemy mobilności indywidualnej jako źródło innowacji w transporcie publicznym 
4.8. Wybrane innowacje organizacyjne ................................................................ 108

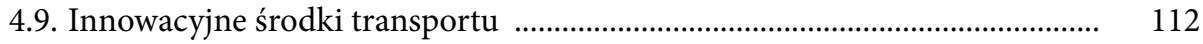

5. Innowacje i ich wpływ na rynek transportu publicznego .................................. 114

5.1. Wdrażanie innowacji jako element realizacji celu publicznego ...................... 114

5.2. Wdrażanie innowacji a efektywność ekonomiczna przedsiębiorstwa ........... 116

5.3. Innowacja a rynek transportu publicznego .................................................... 118

5.4. Innowacje a rynek użytkowników transportu publicznego ............................. 120

Podsumowanie ……………………………………………………………….. 122

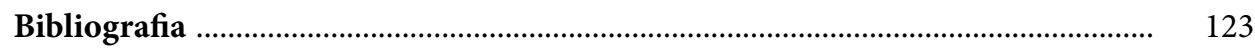

Spis tabel i rysunków ........................................................................................ 137

Summary. Innovations in public transport .......................................................... 139 


\section{WSTĘP OD SCHUMPETERA DO AUTOBUSÓW WODOROWYCH}

Ostatnie stulecie upłynęło pod znakiem innowacji. Innowacja, $\mathrm{z}$ łacińskiego innovatio - odnowienie, jest rozumiana jako coś nowego - produkt, usługa, sposób realizowania działalności. Opracowań na temat innowacji, ich roli we współczesnym przedsiębiorstwie znaleźć można wiele. Sporo jest także literatury na temat konkretnych rozwiązań innowacyjnych w wybranych branżach.

Celem niniejszej publikacji jest stworzenie pierwszego, kompleksowego opracowania na temat wykorzystania innowacji w transporcie publicznym: zebranie dostępnej wiedzy na temat innowacji w przedsiębiorstwach komunikacji publicznej, a także innowacji wprowadzanych $\mathrm{w}$ organizacji przewozów transportu publicznego.

Dodatkowo autor stawia sobie za cel usystematyzowanie wiedzy na temat podstawowych grup stosowanych innowacji, dokonanie analizy tych innowacji pod kątem zgodności z definicją i modelami tworzenia i wdrażania innowacji obecnymi w naukach ekonomicznych. Autor monografii nieustannie poszukuje odpowiedzi na pytania: Czy wprowadzanie innowacji w przedsiębiorstwach transportu publicznego to jedynie zabieg wizerunkowy? Czy też przeciwnie, za wdrażaniem innowacji przemawia realizacja długofalowych celów przedsiębiorstwa (organizacji), a innowacje stanowią element długofalowej strategii rozwoju organizacji i efektywnego zarządzania nią.

Badania te są prowadzone w odniesieniu do rynku transportu publicznego, gdzie usługi mają charakter społeczny i w większości są świadczone przez podmioty samorządowe i państwowe (często jednak działające jako spółki prawa handlowego). W naturalny sposób powstaje zatem płaszczyzna potencjalnego konfliktu między celami społecznymi i związanymi z realizacją celu publicznego a priorytetami zarządczymi związanymi z realizacją celu ekonomicznego - co także jest przedmiotem badań.

Autor ma świadomość, że problematyka zarówno innowacji, jak i ich roli w rozwijaniu transportu publicznego to obszary niezwykle złożone. Wzajemne relacje pomiędzy innowacyjnością przedsiębiorstw a rozwojem transportu publicznego to problem aktualny, ale też niezwykle dynamiczny. Stąd też na etapie tworzenia monografii wykorzystano wiele grup źródeł - zarówno literaturę stricte naukową jak i publikacje popularno-naukowe. Dokonano także analizy materiałów o charakterze bardziej popularnym - to one bowiem, z uwagi na krótszy niż w nauce okres publikacji, bardzo często były źródłem najświeższej wiedzy na temat wdrażanych innowacji.

Niniejsza książka kieruje czytelnika poprzez teorię innowacji do praktyki innowacji w transporcie publicznym - stanowiąc pierwszą na polskim rynku próbę stworzenia katalogu innowacji stosowanych w transporcie publicznym. 



\section{INNOWACJA W TEORII EKONOMII I W NAUKACH O ZARZĄDZANIU}

\subsection{Model powstania innowacji J.A. Schumpetera}

Za ojca teorii innowacji powszechnie uznaje się Josepha Schumpetera - austriackiego ekonomistę, autora teorii wzrostu gospodarczego (1911) i cyklów koniunkturalnych (1939), przedstawiciela teorii ekonomii klasycznej. Stulecie - od momentu pojawienia się Teorii wzrostu gospodarczego do czasów obecnych wyznacza czas analizy procesów innowacyjności. Okres niezwykle dynamiczny w historii świata, pełen zdarzeń o charakterze militarnym i politycznym, zarówno globalnych, jak i o charakterze regionalnym, ale też okres, który zapisał się w historii świata licznymi wynalazkami. I to właśnie te wynalazki stały się źródłem wielu teorii tworzących naukowe podstawy innowacji.

Rozważania na temat innowacyjności w transporcie publicznym nie mogą nie zacząć się od przeglądu dzieł wspomnianego austriackiego ekonomisty. Za najważniejsze prace Schumpetera uznaje się między innymi Teorię rozwoju gospodarczego (1911), Cykle koniunkturalne (1939) i Kapitalizm, socjalizm, demokracje (z 1942). W tych publikacjach znajdujemy podstawy analiz innowacji w naukach ekonomicznych, pokazują one także ewolucję poglądów Schumpetera. Zasadniczo początkowe myśli były rozwijane w kolejnych latach i stały się tym, co dziś uznajemy za „teorię innowacji”.

„Proces rozwoju społecznego stanowi niepodzielną całośc”" (Schumpeter, 1960, s. 1). Określanie faktów jako faktów ekonomicznych, oderwanych od rzeczywistości, samo w sobie oznacza już abstrakcję. Fakty społeczne są rezultatem działania człowieka, fakty ekonomiczne wyznacza przede wszystkim pojęcie „działania ekonomicznego”. „Każdy musi, częściowo przynajmniej działać ekonomicznie i każdy musi albo być podmiotem gospodarującym, albo też zależeć od jakiegoś podmiotu gospodarującego" (Schumpeter, 1960, s. 2).

Zdaniem Schumpetera nie ma ucieczki od rozwoju - zarówno rozwoju w ujęciu społecznym, jak i ekonomicznym. Dziś dokładamy do tego jeszcze trzecią płaszczyznę - rozwoju w ujęciu techniczno-technologicznym. Schumpeter już na samym początku Teorii rozwoju gospodarczego wskazuje na rolę gospodarowania. Rozwój i gospodarowanie stanowią system naczyń połączonych, klucz do analizy zjawisk 
zachodzących zarówno w podmiocie gospodarującym, jak i na większym obszarze - rynku. A zachodzący proces społeczny sprawia, że konsument dąży do tego, aby podejmowane przez niego decyzje były racjonalne.

Jako rozwój rozumieć należy ,jedynie takie zmiany w życiu ekonomicznym, które nie są mu narzucane z zewnątrz, lecz powstają z jego własnej inicjatywy, od wewnątrz" (Schumpeter, 1960, s. 99). Występują one w życiu przemysłowym i handlowym, a nie w samych potrzebach konsumentów. Produkcja oznacza kombinację czynników produkcji - materiałów i sił celem zaspokojenia potrzeb. Produkcja innych rzeczy lub tych samych rzeczy innymi metodami oznacza inną kombinację materiałów i sił. Nowa kombinacja oznacza zmianę, może także oznaczać wzrost, ale nie powoduje powstawania nowego zjawiska ani rozwoju. Z jednym wyjątkiem: „jeśli nowe kombinacje występują w sposób nieciągły, wówczas powstaje zjawisko charakterystyczne dla rozwoju”. Te nowe kombinacje środków produkcji będą zatem rozwojem w rozumieniu Schumpetera (1960, s. 103-104).

Schumpeter zakłada w swojej teorii (1960, s. 104), że rozwój oznacza jeden z pięciu możliwych przypadków:

1. „Wprowadzenie nowego towaru - to jest towaru, $\mathrm{z}$ jakim konsumenci nie są jeszcze obeznani - lub nowego gatunku jakiegoś towaru.

2. Wprowadzenie nowej metody produkcji, tj. metody jeszcze niewypróbowanej praktycznie w danej gałęzi przemysłu; metoda ta może nie polegać na nowym wynalazku naukowym, ale na przykład na nowym handlowym sposobie postępowania $\mathrm{z}$ jakimś towarem.

3. Otwarcie nowego rynku, tj. rynku, na którym dana gałęź przemysłu danego kraju nie była uprzednio wprowadzona, bez względu na to, czy rynek ten istniał przedtem, czy nie istniał.

4. Zdobycie nowego źródła surowców lub półfabrykatów, i to znów niezależnie od tego, czy źródło to już istniało czy też musiało być dopiero stworzone.

5. Przeprowadzenie nowej organizacji jakiegoś przemysłu, na przykład stworzenie sytuacji monopolistycznej (na przykład w drodze utworzenia trustu) lub złamanie pozycji monopolistycznej".

Wskazanych powyżej „pięć przypadków” stało się w praktyce źródłem definicji innowacji. Powyższa definicja sprawdza się przede wszystkim w tych warunkach, w których funkcjonuje konkurencja i współzawodnictwo. To wtedy bowiem jest szansa, aby „nowe kombinacje” wypierały stare. Na drodze tego zjawiska stoi wiele przeszkód - od wszystkich mniej konkurencyjnych form rynku aż po współczesne zmiany gospodarcze - globalizacja i tworzenie międzynarodowych koncernów postrzegane jest często jako sposób ograniczania konkurencji.

Schumpeter (1960) zwraca jeszcze uwagę na kilka zależności i zasad, bez których niemożliwe byłoby wprowadzanie nowych kombinacji. Jak zapisano już wcześniej, nowe kombinacje wypierają stare kombinacje i nie powinny być z założenia efektem zastosowania niewykorzystanych środków produkcji, a wręcz przeciwnie - powinny 
zabierać potrzebne środki produkcji ze starych kombinacji (z różnych powodów). Aby nowe kombinacje mogły zaistnieć, potrzebne jest dysponowanie środkami produkcji. Ciekawym elementem jest także konieczność osiągania kompromisów nowa kombinacja czynników produkcji może wymagać poniesienia „ofiary” i „wyrzeczeń" związanych z rezygnacją starej kombinacji czynników produkcji. Istnieje także związek pomiędzy innowacją a kredytem - zwłaszcza dla nowych kombinacji kredyt jest bowiem często niezbędny jako element mechanizmu finansowania.

Ciężar ekonomicznego rozwoju spoczywa na przedsiębiorstwach innowacyjnych. A kapitalistyczne elity to grupa cichych biznesmenów, którzy potrafią wykorzystać innowacje do tworzenia dochodu (Schumpeter, 1966).

Teoria Schumpetera jest osadzona w realiach mikroekonomicznych. „Joseph A. Schumpeter uważał, że do analizy zmian gospodarczych niezbędne jest zrozumienie równowagi ogólnej. Ogólna równowaga jest płaszczyzną odniesienia zmian, która umożliwia obserwację i opis mechanizmu reakcji systemu ekonomicznego na bodźce (apparatus of response z odpowiednio adaptive i creative response)" (Glapiński, 2012, s. 3). Zgodnie z schumpeterowskim założeniem konieczności zrozumienia ogólnej równowagi rynkowej w kolejnym podrozdziale wskazane zostaną wybrane elementy teorii mikroekonomii odnoszące się do mechanizmów kształtowania i funkcjonowania rynku. To rynek bowiem napędza rozwój i determinuje innowacyjność przedsiębiorstw. Bez rynku i mechanizmów nim rządzących nie byłoby presji. A jak wiadomo, to potrzeba zwykle jest matką wynalazków.

Ewolucja poglądów Schumpetera oznaczała między innymi, że hasło innowacji nie pojawiło się od razu. Droga do niego wiedzie przez wspomniany już rozwój gospodarczy i jego elementy. Jak wskazuje Glapiński (2012), nowa kombinacja czynników produkcji wynika z jednej z pięciu przyczyn: wprowadzenia na rynek nowego produktu lub usługi, zastosowania nowej metody produkcji, otwarcia nowego rynku zbycia, zdobycia nowego surowca czy nowej formy organizacyjnej przemysłu. „Wszystkie te przypadki Schumpeter określa jako formy przejawiania się zjawiska, które definiuje w Teorii rozwoju gospodarczego jako nowe kombinacje, następnie jako przedsięwzięcia, a ostatecznie, w Business cycles..., jako innowacje." (Glapiński, 2012, s. 5).

Innowacje są powszechnie uznawane za czynnik napędzający rozwój - zarówno w rozumieniu techniczno-technologicznym, jak i organizacyjnym. Coraz częściej jednak uznaje się je także za element niezbędny w każdym procesie gospodarowania. Tym samym innowacyjności należy dziś poszukiwać nie tylko w sektorze prywatnym, ale także publicznym, i to nie tylko w celu podniesienia konkurencyjności, ale aby poprawić wspomnianą efektywność realizacji procesów w różnych obszarach.

W literaturze przedmiotu można wyróżnić dwa zasadnicze podejścia do przedsiębiorczości - od strony przyczynowości (źródeł - podejście podmiotowe) i od strony przejawów przedsiębiorczości (przedmiotowe). W ujęciu podmiotowym, stanowiącym o przedsiębiorczości w ujęciu pierwotnym, Schumpeter wskazuje na 
siłę sprawczą innowacyjnych zmian. Siłą tą jest przedsiębiorca: nośnik zmian, jednostka zdolna do wprowadzania nowych kombinacji czynników produkcji, a więc do realizacji innowacji (Kaliszczak, 2011).

Jak wskazuje Drucker (1992, s. 29), „Innowacja jest szczególnym narzędziem przedsiębiorców, za pomocą którego ze zmiany czynią okazję do podjęcia nowej działalności gospodarczej lub do świadczenia nowych usług. Można ją przedstawić jako dyscyplinę, można się jej nauczyć, można ją praktykować. Przedsiębiorcy powinni w celowy sposób szukać źródeł innowacji, szukać zmian i ich objawów wskazujących na okazję do skutecznej innowacji. Powinni także znać i stosować zasady skutecznej innowacji”.

Powyższe słowa Druckera to nic innego jak drogowskaz dla przedsiębiorców, którędy należy podążać w poszukiwaniu rozwoju. Uznając innowację za narzędzie, Drucker wskazuje szeroki wachlarz możliwości, jakie daje ona przedsiębiorcom. Co ważne, teorię tę można odnieść nie tylko do przedsiębiorstw - znajdzie ona zastosowanie także w odniesieniu do instytucji i innych organizacji. A łącząc „narzędziowość" wskazywaną przez Druckera z szerokim zakresem wskazywanym przez Schumpetera, uzyskamy narzędzie o szerokim spektrum oddziaływania i wielu oferowanych możliwościach.

Innowacyjność i przedsiębiorczość są bardzo mocno powiązane z efektywnością gospodarowania, ale także z kreowaniem postaw prospołecznych, aktywnością obywatelską. Stąd coraz większa rola takich pojęć, jak ekonomia społeczna czy gospodarka społeczna - wsparcie dla tych procesów, których ekonomia i rynek nie mogą skutecznie rozwiązać. Stąd mowa o wzajemnych powiązaniach - sektora publicznego, prywatnego i organizacji trzeciego sektora (Czyżewska, Pach i Sala, 2020).

"Innowacje są kategorią multi- i interdyscyplinarną oraz wielopłaszczyznową" (Błach, 2018, s. 19), są utożsamiane z przedsiębiorczością, tworzeniem i dyfuzją nowych rozwiązań, ale też realizowane w określonym otoczeniu. Opisuje się je jako efekt komercjalizacji kreatywności, czteroetapowy proces. W skład tego procesu wchodzą: inicjacja - identyfikacja potrzeb, implementacja - wprowadzenie innowacji i jej popularyzacja, dyfuzja - rozpowszechnianie innowacji, oraz absorpcja wejście wspomnianej innowacji w sposób myślenia i działania przedsiębiorstw czy regionów (Błach, 2018).

Dyfuzją innowacji nazywamy szerszy proces związany $z$ wprowadzaniem innowacji na rynek. Dyfuzja innowacji ma w sobie elementy z zakresu psychologii, tworzenia strategii, analizy rynku czy marketingu i analizy technologii. To rodzaj przemiany związanej z przyjęciem lub odrzuceniem innowacji. Jako proces składa się z czterech podstawowych elementów: innowacji, kanału komunikacji, czasu i systemu społecznego (Gwarda-Gruszczyńska, 2017).

Ważnym elementem dyfuzji innowacji jest także przekonanie odbiorców do samego produktu. Działania marketingowe to za mało - marketing to bowiem pozycjonowanie i przekonywanie odbiorców do produktu już wcześniej przez nich 
zaakceptowanego, obecnego w świadomości odbiorców. Wówczas można mówić o budowaniu marki, jej postrzeganiu przez odbiorców. Najpierw należy jednak wprowadzić innowacyjny produkt na rynek (Muras i Zabłocki, 2013).

W związku z coraz powszechniejszym wyodrębnianiem „ekonomii społecznej” czy "gospodarki społecznej” w naukach o zarządzaniu zaczęto identyfikować także innowacje społeczne - jako źródło, ale i skutek przedsiębiorczości społecznej. Mają one być odpowiedzią na rozwiązywanie problemów o charakterze społecznym, dotykających wszystkie te grupy społeczne, które potrzebują wsparcia zewnętrznego - społeczeństwa czy państwa (Górka, Łuszczyk i Thier, 2019).

W naukach ekonomicznych i związanej z nimi literaturze za innowację uznaje się wszelkie zmiany i wprowadzanie nowości czy idei. Obok Schumpetera swoje definicje innowacyjności formułują Drucker czy Freeman. Powszechnie wykorzystuje się także definicję OECD określającą innowację jako zastosowanie nowych lub udoskonalonych dóbr, procesów, metod marketingowych i organizacyjnych, zmian czy organizacji pracy (Ślusarczyk, 2020).

Innowacyjność przedsiębiorstw jest efektem między innymi ciągłego rozwoju społeczno-ekonomicznego oraz zmian warunków funkcjonowania czy ciągłego wprowadzania nowych produktów i usług na rynek. Innowacyjność jest wymuszona przez potrzeby i oczekiwania nabywców - służy budowaniu zainteresowania klientów oraz zaspokajaniu ich potrzeb. Przyspieszenie gospodarki wymusza innowacyjność, dynamizują się procesy konkurencyjne, a produkt czy usługa wraz z wartościami oddanymi staje się decydującym narzędziem w walce konkurencyjnej. Rozwój przedsiębiorstwa i poprawa jego wyników są zatem uzależnione od innowacji pod postacią nowych czy wzbogaconych produktów (Sosnowski i Nowakowski, 2020).

Czynników wpływających na potrzebę innowacji jest wiele. Kozioł-Nadolna i Suchocka (2020) wskazują między innymi postęp technologiczny, zmiany zachowania konsumentów, ograniczone zasoby, krótki cykl życia produktów, wzrost konkurencyjności czy ogólnie - zmieniający się biznes. Innowacje produktowe, marketingowe czy organizacyjne mają być źródłem przewagi konkurencyjnej, prowadzić do rozwoju organizacji i zmiany biznesowych modeli działania.

Klasyczne rozumienie innowacji jako zmiany technologicznej ulega przeobrażeniu na poziomie nie tylko przedsiębiorstw, ale także gospodarki światowej. Na poziomie Unii Europejskiej także dostrzega się rolę innowacyjności jako determinującej transformację i rozwój poszczególnych regionów. Przedsięwzięcia innowacyjne są postrzegane jako dające możliwość tworzenia przewagi konkurencyjnej, umacniania pozycji na rynku i zapewnienia sobie możliwości przetrwania. A polityka UE w zakresie innowacyjności pozostaje w zgodnie z innymi politykami, chociażby w zakresie energetyki, zatrudnienia, środowiska czy przemysłu. Badania naukowe $\mathrm{i}$ innowacje to jeden $\mathrm{z}$ obszarów działania UE, a inwestycje $\mathrm{w}$ badania naukowe i innowacje są traktowane jako inwestycje w przyszłość Europy i konkurencyjność UE na rynkach światowych (Mucha, 2020). 
Poza podstawowym podziałem na innowacje produktowe, procesowe, organizacyjne czy marketingowe można wskazać także jeszcze inne rodzaje innowacji.

Innowacje inkluzywne to takie, które włączają w proces tworzenia grupy społeczeństwa tradycyjnie niezaangażowane $\mathrm{w}$ rozwój, na przykład biedne warstwy społeczne (Murzyn, 2020, za: Foste i Heeks, 2013). Chodzi o zaspokajanie potrzeb społeczności lokalnych, zgodnie z definicją pojęcia inkluzywności, czyli z uwzględnieniem „całości” czy też „łączenia całości”. Kluczową cechą innowacji tego rodzaju jest dostępność dla wszystkich grup społecznych - także osób o najniższych dochodach czy wykluczonych z innych przyczyn. Celem jest tu maksymalne poszerzenie odbiorców innowacji na całe społeczeństwo (Murzyn, 2020). Należy także zauważyć, że innowacjom inkluzywnym blisko jest do innowacji społecznych. Poszczególne rodzaje innowacji nie funkcjonują samoistnie, lecz współzależnie z procesami, wzajemnie się przenikają i powodują powstawanie kolejnych zmian (na przykład od innowacji technologicznych do społecznych, od społecznych do inkluzyjnych) (Murzyn, 2020).

Innowacje możemy podzielić na radykalne i przyrostowe. Te pierwsze są całkowicie różne i nowe dla przedsiębiorstwa, potrzebują czasu, środków i wiedzy. Te drugie obejmują rozwój już istniejącej usługi, produktu czy procesu w celu zwiększenia zadowolenia klienta, efektywności, poprawy jakości czy obniżenia kosztów (Kozioł-Nadolna i Suchocka, 2020).

Istnieje także koncepcja innowacji otwartych. Zgodnie $\mathrm{z}$ ich klasyczną definicją powstają one i są realizowane jako następstwo współpracy przedsiębiorstwa z partnerami zewnętrznymi - w szczególności dotyczy to dzielenia się zasobami wiedzy. Innowacje tego typu powinny wykorzystywać szerokie spektrum zasobów wewnętrznych i zewnętrznych, a źródłem ich powstania i rozwijania jest wspomniany transfer wiedzy. Zagadnienie otwartych innowacji oznacza zatem między innymi wyzwania związane ze współpracą różnych organizacji przy ich tworzeniu czy też zarządzania wiedzą w procesie tworzenia otwartych innowacji (Sopińska i Dziurski, 2018).

Można także mówić o innowacjach zarządczych - które dotyczą zarówno zewnętrznych, jak i wewnętrznych czynników oddziaływujących na przedsiębiorstwo. Wśród czynników o charakterze zewnętrznym wskazuje się między innymi czynniki rynkowe i technologiczne, czynniki wewnętrzne to z kolei kultura organizacji, profil przedsiębiorstwa, styl zarządzania i cechy kadry kierowniczej (Kraśnicka, 2018).

Ciekawą formą innowacji są innowacje finansowe. Są one kreowane w systemie finansowym i same w sobie stanowią osobny obszar badań - zarówno z uwagi na złożoność, jak i różne podejścia klasyfikacyjne. Innowacje te można łączyć praktycznie ze wszystkimi definicjami innowacji - $\mathrm{w}$ tym procesowymi czy produktowymi. W praktyce innowacje finansowe oznaczają zatem wprowadzanie nowych produktów, usług czy sposobu organizacji procesów w odniesieniu do rynków 
finansowych. Zmiany funkcjonowania instytucji finansowych, sekurytyzacja, rozwój finansów alternatywnych - to wszystko napędza rozwój innowacji finansowych. Wśród ważnych cech innowacji finansowych należy wskazać poziom ich abstrakcji czy krótki cykl życia. Mają one charakter cykliczny, związany z występującymi cyklami ekonomicznymi (Błach, 2018).

Innowacje ekologiczne to taka zmiana procesu (na przykład produkcyjnego), która prowadzi do zmniejszenia wpływu na środowisko, obniżając negatywny wpływ działalności człowieka. Taka innowacja (zwana też ekoinnowacją) może mieć charakter produktowy, procesowy (technologiczny) lub organizacyjny (Gajda i Bajdur, 2016).

Kwestie odpowiedzialności za środowisko naturalne oraz zrównoważony rozwój są dziś często poruszanym tematem. Charakterystyka innowacji związanych z ochroną środowiska naturalnego staje się też ważnym tematem badawczym - chociażby w zakresie tego, jak dużą rolę we wdrażaniu ekoinnowacji odgrywa gromadzenie wiedzy na ich temat (Marczewska, 2016).

\subsection{Równowaga ogólna a równowaga rynku}

Istotą rynku jest spotykanie się ze sobą decyzji gospodarstw domowych (dotyczących konsumpcji różnego rodzaju dóbr) i decyzji przedsiębiorstw (dotyczących tego, co i jak wytwarzać), a także decyzji samych pracowników (jak wiele i dla kogo pracować) - wzajemnie uzgodnionych dzięki odpowiedniemu dostosowaniu cen. Ceny te w odniesieniu do podstawowych zasobów (praca, ziemia, maszyny) są kształtowane w taki sposób, aby zapewnić wykorzystanie ograniczonych zasobów na te dobra i usługi, na które występuje społeczne zapotrzebowanie (Begg, Fischer i Dornbusch, 2003).

Ta podstawowa definicja z obszaru mikroekonomii wskazuje, czym jest i jakimi decyzjami kieruje się rynek. Rynek, który - choć niepozbawiony wad i niedogodności - jest po dziś dzień najlepszym mechanizmem kontroli produkcji dóbr i usług. Najlepszym, gdyż wykorzystuje naturalne mechanizmy zapotrzebowania po stronie odbiorców - sprzyjając produkcji tych wyrobów i usług, których odbiorcy oczekują. Wybrane modele organizacji rynku przedstawiono w rozdziale 3.

Zgodnie $\mathrm{z}$ definicją tzw. wolnego rynku możliwe jest ustalanie cen wyłącznie $\mathrm{w}$ wyniku gry pomiędzy popytem a podażą. W praktyce często występuje interwencja państwa, wpływająca na wzajemną relację popytu i podaży, tworząca reguły i przepisy uniemożliwiające kształtowanie cen wyłącznie wynikających z mechanizmu tworzenia poziomu równowagi rynkowej. Kontrola cen może oznaczać pojawienie się ich minimalnej lub maksymalnej wartości (Begg i in., 2003). 
Warto wspomnieć o tych zależnościach, bowiem w praktyce kształtowania usług transportu publicznego nie będziemy mieli pełnej dowolności w zakresie polityki cenowej, a działanie wybranych mechanizmów rynkowych zostanie w wybranych obszarach częściowo, a nawet całkowicie wyłączone. To wszystko sprawia, że omawiana tematyka staje się niezwykle ciekawa, bowiem do głosu będą dochodzić także czynniki niezwiązane bezpośrednio z równowagą rynkową.

Konstruowanie taryf $\mathrm{w}$ systemie transportu publicznego jest zadaniem złożonym. Zwykle stosuje się tu jeden $\mathrm{z}$ typowych modeli opartych na biletach jednorazowych i okresowych, odcinkowych czy strefowych. $Z$ uwagi na złożony proces decyzyjny związany z zatwierdzaniem taryf w sektorze publicznym nie jest możliwe dynamiczne zmienianie taryf $\mathrm{z}$ dnia na dzień, a w danym okresie można je uznać za stałe. Tym samym nie ma możliwości dynamicznej zmiany ceny za usługę w zależności od aktualnego popytu.

W transporcie publicznym w miastach zwykle nie odnosi się ceny przejazdu do popytu na przewozy na danej linii czy w konkretnej porze dnia. Cena ustalona „systemowo" ma być atrakcyjna dla odbiorcy usługi publicznej, a niekoniecznie zgodna $\mathrm{z}$ faktycznie ponoszonymi kosztami. W praktyce bowiem występuje dotowanie usługi publicznej. Należy też wskazać, że elementem dodatkowym funkcjonującym w tym systemie są uprawnienia do przejazdów bezpłatnych czy ulgowych mające charakter ulg ustawowych czy handlowych. One również wpływają na stronę przychodową w systemie transportu publicznego.

Wszystkie te elementy sprawiają, że usługi transportu publicznego nie można rozpatrywać jako regulowanej prostymi rynkowymi mechanizmami. Zasada popytu i podaży w praktyce nie do końca obowiązuje. O ile bowiem w przypadku zwiększonego popytu na przewozy na danej trasie, linii czy kursie często możliwe jest zwiększenie podaży, o tyle w przypadku zbyt małego popytu połączenia często i tak są utrzymywane - tworząc podstawowy kształt oferty przewozowej, mającej charakter usługi publicznej i dostępnej dla ogółu społeczeństwa.

Równowaga w transporcie publicznym oznacza zatem wzajemne oddziaływanie i bilansowanie się poszczególnych elementów systemu nie tylko zgodnie z teorią ekonomii, ale także w szerszym kontekście funkcjonowania miasta i świadczenia usług dla lokalnej społeczności. A równowaga systemu transportu miejskiego nie musi być równoważna chociażby z równowagą rynkową. Przykładem gwałtownego oddziaływania na równowagę systemu transportu publicznego była reorganizacja systemów transportowych w marcu 2020 roku wraz z pojawieniem się globalnej pandemii.

Ponieważ mowa o innowacyjności w perspektywie całego rynku, warto zwrócić uwagę na mechanizmy, które mogą tę innowacyjność wspierać. Chodzi tu o politykę innowacyjną na poziomie krajowym, czyli tworzenie takich rozwiązań, które będą wspierały tworzenie i komercjalizację innowacji, a także o różne rodzaje aktywności wspierające proces innowacyjny na wielu poziomach. 
Jako formy wsparcia działalności badawczo-rozwojowej można wskazać między innymi ulgi podatkowe, kredyty na działalność innowacyjną, państwowe gwarancje dla kredytów udzielanych przedsiębiorstwom czy zmniejszenie rygorów w zakresie przyznawania statusu centrum badawczo-rozwojowego - zarówno jednostkom naukowym, jak i przedsiębiorstwom (Janasz i Wiśniewska, 2017).

\subsection{Klasyczne i współczesne koncepcje klasyfikacji innowacji}

Należy zauważyć, że innowacje są uznawane przez większość autorów jako coś, co z natury rzeczy jest zjawiskiem pozytywnym - prowadzi bowiem do powstawania korzyści o charakterze ekonomicznym. A racjonalnie gospodarujący przedsiębiorca nie wdrażałby zmian, z których nie widziałby korzyści - teraz lub w przyszłości. Zgodnie $\mathrm{z}$ taką definicją innowacji rozwiązania, które nie są $\mathrm{w}$ stanie spełnić kryteriów związanych z odpowiednią efektywnością, nie mogą stać się innowacjami, a ich wdrożenie musi być uwarunkowane zmianą parametrów ekonomicznych, rynkowych czy środowiskowych. W definiowaniu pojęcia innowacji można wyróżnić dwa podejścia: wynikowe i procesowe. W podejściu wynikowym innowacja skutkuje wprowadzeniem nowego produktu, usługi czy procesu. W podejściu procesowym innowacja stanowi sekwencję działań, które zmierzają do „zastosowania nowych/ udoskonalonych rozwiązań" (Osbert-Pociecha, 2018, s. 19-20).

Analizując działalność innowacyjną, a także typologię innowacji, można zwrócić uwagę, że większość badaczy skupia się na typowych rodzajach innowacji, a powinni raczej szukać mniej zbadanych typów innowacji, skupiających się na celach, obywatelu czy polityce (Chen, Walker i Sawhney, 2019).

Działalność innowacyjna może być klasyfikowana ze względu na lokalizację względem struktury organizacji. Może być bowiem prowadzona wewnątrz organizacji, na zewnątrz - poprzez nabywanie wiedzy ze źródła zewnętrznego - lub też w sposób mieszany, łącząc dwie wymienione wcześniej formy (Kłos, 2017)

W literaturze przedmiotu można znaleźć co najmniej kilka opracowań, w których autorzy dokonują klasyfikacji innowacji i oceny ich roli w historii myli ekonomicznej. Na przykład Gust-Bardon (2012) w przeprowadzonym przeglądzie myśli ekonomicznej wskazuje jako związanych z postępem technicznym, wynalazkami i innowacjami następujących autorów: Smith, Ricardo, Say, Mill, Marx, Marshall, Tarde, Veblen, Pigou, Schumpeter i Kalecki. Z kolei Kozioł-Nadolna i Suchocka (2020) wskazują jako najczęściej uznawanych z literaturze twórców teorii dotyczących innowacji: Schumpetera, Smitha, Saya, Tarde’a czy Kaleckiego, zauważając, że 
następców Schumpetera różni między innymi podejście do ponownego wdrożenia raz wdrożonego wynalazku (zdaniem niektórych wciąż można go uznawać za innowację). Osbert-Pociecha (2018, s. 17-18) wskazuje jako twórców teorii dotyczących innowacji między innymi Schumpetera, Druckera, Freemana, Mansfielda, Whitfielda, Pomykalskiego czy Dolińską. Jako szczególnie istotne w kontekście niniejszej publikacji należy uznać poglądy między innymi Marshalla i Tarde’a.

$\mathrm{Na}$ etapie interpretacji definicji innowacji pojawia się wiele wyraźnych rozbieżności. Zwykle mówi się o dwóch znaczeniach innowacji: rzeczowym i funkcjonalnym (czynnościowym). W pierwszym przypadku jest to innowacja przyswojona przez organizację czy człowieka, w drugim - innowacja dotyczy procesu tworzenia. Proces ten jest zwykle utożsamiany z tworzeniem innowacji o charakterze rzeczowym (Kamiński, 2018).

Ponieważ w literaturze przedmiotu znajduje się bardzo wiele różnych definicji odnoszących się do innowacji, można mieć wrażenie, że panuje tutaj terminologiczny chaos. Ujednolicenie pojęć stało się niezbędne na poziomie Unii Europejskiej, aby móc efektywnie wspierać innowacyjność państw członkowskich. W tym celu, pod kierunkiem OECD i Eurostatu, powstał Podręcznik Oslo manual (Pieniacka, 2018).

W swoim podstawowym, uznawanym dziś za klasyczne, rozumieniu innowacji Drucker wskazuje siedem potencjalnych źródeł i okazji do innowacji, dzieląc je na wewnętrzne i zewnętrzne. Ich rozkład przedstawiono na rysunku 1.1.

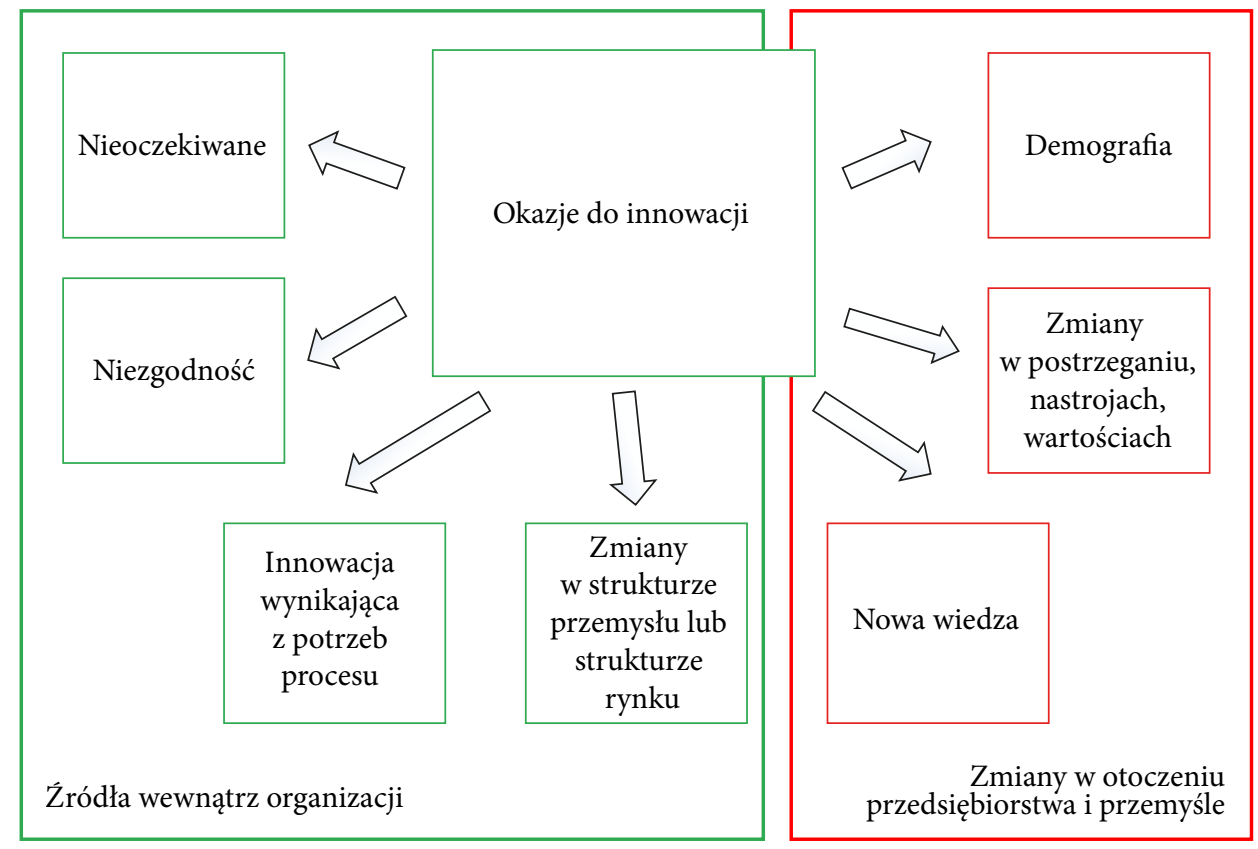

Rysunek 1.1. Okazje do innowacji według Druckera

Źródło: (Drucker, 1992, s. 44). 
Podręcznik Oslo (Oslo manual) to dokument zawierający zalecenie dotyczące pozyskiwania, prezentowania i wykorzystywania danych z zakresu innowacji - ma on na celu wspieranie pomiarów działalności naukowo-technicznej i innowacyjnej. Podręcznik ten ma charakter międzynarodowy - tworzyły go: UNESCO, Bank Światowy i wiele regionalnych banków rozwoju. Obecna wersja podręcznika została wydana w 2018 roku$^{\star}$ i ma stanowić wsparcie także w ocenie celów zrównoważonego rozwoju. Podręcznik Oslo zawiera zalecenia dotyczące gromadzenia i interpretacji danych związanych $\mathrm{z}$ innowacjami, powstał między innymi po to, aby ułatwić gromadzenie danych na temat innowacji i ich sprawozdawczość - poprzez wspólną terminologią czy uzgodnienie zasad i konwencji praktycznych (Podręcznik Oslo, 2020). Obecna edycja podręcznika jest czwartą. Pierwsza pojawiła się w 1992 roku i dotyczyła innowacji w przemyśle wytwórczym (nazwa pochodzi od miasta, w którym zalecenia te zatwierdzono po raz pierwszy). Kolejne wydania wprowadzają dalsze rozszerzenia do podręcznika, zgodnie $\mathrm{z}$ aktualnymi potrzebami. Wydanie czwarte ma na celu między innymi wzmocnienie roli tej publikacji jako źródła wskazówek w zakresie innowacyjności zarówno na poziomie koncepcyjnym, jak i technicznym (Podręcznik Oslo, 2020).

Podręcznik Oslo (2020) jako podstawę koncepcyjną dla pomiaru innowacji wskazuje przede wszystkim prace z zakresu zarządzania i ekonomii, powołując się na Smitha czy Schumpetera, ale także teorię dyfuzji Rogersa.

Zgodnie z teorią dyfuzji Rogersa (1962, za: Podręcznik Oslo, 2020) innowacje są komunikowane i przyjmowane po określonym czasie przez uczestników całego systemu społecznego. Z kolei Nelson i Winter (1982, za: Podręcznik Oslo, 2020) przyjmują, że innowacje są elementem powstałym na bazie dotychczasowych działań jako proces zależny. Przedstawiane w Podręczniku Oslo (2020) teorie innowacji innych autobusów (model powiązań łańcuchowych i teoria systemów innowacji) wskazują, że innowacje nie mają charakteru procesu liniowego i sekwencyjnego, ale wymagają wielu interakcji i są związane z procesem uczenia.

Pojęcie innowacji opiera się na wiedzy. To praktyczne zastosowanie istniejących lub nowo tworzonych informacji i wiedzy. Wiedza jest tu traktowana jako zdolność rozumienia informacji i wykorzystania jej do konkretnych celów. Innowacje mogą powstawać między innymi jako efekt działalności badawczo-rozwojowej $(B+R)$. W tym miejscu należy wskazać drugi ważny dokument stanowiący źródło wiedzy na temat innowacji, a przede wszystkim - związanej z nimi działalności badawczo-rozwojowej. Mowa o tzw. Podręczniku Frascati.

Podręcznik Frascati to źródło zaleceń dotyczących pozyskiwania i prezentowania danych z zakresu działalności badawczej i rozwojowej. Aktualna wersja pochodzi

* Oficjalną polską wersję językową Oslo Manual 2018 zaprezentowano w 2020 roku, za przekład na język polski odpowiada Główny Urząd Statystyczny. 
z roku $2015^{\star}$. Działalność badawcza i rozwojowa jest bowiem coraz częściej postrzegana jako ważny wkład w innowacje i innowacyjność, a analiza badań i rozwoju na szczeblu krajowym pozwala na poznanie ich szerszego kontekstu związanego ze współtworzeniem innowacyjności. Działania OECD związane z innowacyjnością doprowadziły do stworzenia nazywanej niekiedy „rodziną Frascati” bazy podręczników, do której obok wskazanego Podręcznika Frascati zaliczany jest także Podręcznik Oslo (Podręcznik Frascati, 2018).

Co jest, a co nie jest innowacją według Podręcznika Oslo? Wymogiem minimalnym, aby mówić o innowacji, jest obecność co najmniej takich cech, które nie były wcześniej udostępnione użytkownikom przez daną organizację. Co ważne, cechy te nie muszą być nowe w skali całej gospodarki czy konkretnego rynku, innowacja może bowiem się opierać na produktach lub procesach, które były już wcześniej wykorzystywane na innych rynkach czy produktach. Mowa wówczas o dyfuzji - cennym zjawisku, które może mieć dużą wartość gospodarczą i społeczną (Podręcznik Oslo, 2020).

Mówiąc o innowacjach, badacze skupiają się często na roli Podręcznika Oslo. Jest ona bardzo ważna, nie należy jednak pomijać drugiego z podręczników, wskazanego Podręcznika Frascati. Wyznaczając drogę dla działalności badawczo-rozwojowej, Podręcznik Frascati wskazuje bowiem pośrednio drogę dla innowacji, pełni funkcję narzędzia wspierającego badaczy, tworzy podwaliny dla badań statystycznych w tym obszarze, stanowi ważny kierunek w powiązanych ze sobą obszarach badań i innowacji, tym bardziej że autorzy obu podręczników wskazują ich wzajemne uzupełnianie się. I dopiero spojrzenie na oba dokumenty pozwala na stworzenie pełnej podstawy dla badań, rozwoju i związanej z nimi innowacyjności.

Sposób podejścia do innowacji zmienia się, tak jak zmienia się otaczająca nas rzeczywistość. Cyfryzacja procesów, globalizacja handlu, szeroki dostęp do wiedzy i gospodarka oparta na wiedzy - to wszystko nie pozostaje bez wpływu na myślenie o innowacjach.

Obecnie coraz rzadziej mówi się o tworzeniu innowacji w modelu zamkniętym - gdzie proces innowacyjny jest oparty na własnych zasobach. Coraz trudniej stworzyć innowację na skalę światową, funkcjonuje model tzw. otwartej innowacji (open innovation). W modelu otwartym podstawową zasadą jest maksymalizacja wartości płynącej z różnych pomysłów pojawiających się w przedsiębiorstwie i poza przedsiębiorstwem. Najważniejszym elementem tej koncepcji jest korzystanie nie tylko $\mathrm{z}$ własnych badań, ale także $\mathrm{z}$ wiedzy rozpowszechnianej i dostępnej, gdyż wiedzę należy nabywać, a także dzielić się nią z innymi (Kozioł-Nadolna, 2014).

* Oficjalną polską wersję językową Podręcznika Frascati 2015 zaprezentowano w 2018 roku, za przekład na język polski odpowiada Główny Urząd Statystyczny. 


\subsection{Miejsce innowacji w naukach o zarządzaniu}

Za paradygmat przyjmuje się powszechnie uznawane osiągnięcia naukowe, które mogą dostarczać modelowych problemów i rozwiązań (Kuhn, 2009). Skoro zatem tyle mówi się dziś o innowacji, to czy można przyjąć, że obowiązującym paradygmatem jest paradygmat innowacyjnego przedsiębiorstwa?

Zdaniem Kraśnickiej (2018), gdyby przyjąć takie założenie, to istotne są dwa wzajemnie powiązane ze sobą elementy. Po pierwsze - odniesienie do szerszego kontekstu zmian organizacyjnych traktowanych jako innowacyjne zarówno w ujęciu technicznym, jak i nietechnicznym. Nowy paradygmat obejmuje także innowacje dotyczące zarządzania - tzw. management innovation, a także innowacje o charakterze organizacyjnym i administracyjnym. Zmiany w modelach działalności innowacyjnej to efekt zmian warunków, w których funkcjonują przedsiębiorstwa. Podsumowując rozważania na temat postrzegania paradygmatów zarządzania organizacjami, można zauważyć, że innowacje są głęboko zakorzenione w zarządzaniu organizacjami, zwłaszcza gdy są to przedsiębiorcy. A model działalności innowacyjnej jest przedmiotem nieustannych zmian i dostosowywania do specyfiki przedsiębiorstwa. W dwóch wyraźnie zauważalnych nurtach dotyczących innowacji kładzie się nacisk na proces i realizowaną sekwencję czynności lub też na rezultat, czyli wdrożenie nowego rozwiązania (Kraśnicka, 2018).

Zarządzanie, jako skomplikowany proces, ma w literaturze wiele definicji. Ich rozbieżność to efekt między innymi skupiania się na wybranych elementach tego złożonego procesu.

W odniesieniu do przedsiębiorstwa mówi się zwykle o triadzie pojęć: zarządzanie, efektywność i rozwój, zespolonych przez czynniki ludzki. To człowiek jest uznawany za najważniejszy element organizacji - gdyż ma zdolność do formułowania celów i wyznaczania możliwych metod i sposobów działań (Borowiecki, Siuta-Tokarska i Żmija, 2017). Analizując innowacyjność przedsiębiorstwa, należy się skupić na rozwoju, nie zapominając jednak o efektywności czy sprawności szeroko pojętego zarządzania.

Rozwój przedsiębiorstwa następuje w kilku podstawowych wymiarach. Rozwój w wymiarze ekonomicznym to przede wszystkim efektywność gospodarowania, zarządzanie inwestycjami czy innymi przedsięwzięciami o charakterze rynkowym. Potencjał przedsiębiorstwa, polityka finansowa, marketing i rynek wpływają na możliwości odnoszenia sukcesu na płaszczyźnie ekonomicznej. Rozwój w wymiarze organizacyjnym oznacza dbałość o jakość systemu zarządzania, realizacji procesów, tworzenia i rozwijania zespołów ludzkich. Ważnym elementem jest tu czynnik personalny, rozumiany zarówno jako zbiorowość pracowników, jak i pojedynczy pracownicy, razem tworzący system zasobów ludzkich. Ważnym wymiarem jest czynnik informacyjny - określany jako składający się z przygotowania informacji 
i funkcji komunikacji. Z kolei wymiar techniczno-produkcyjny to takie elementy, jak badania i rozwój czy działalność o charakterze operacyjnym (Stabryła, 2017).

Tylko ciągłe doskonalenie poprzez stałe wdrażanie innowacji może być źródłem sukcesu rynkowego - przedsiębiorstwa muszą bowiem pamiętać o takich elementach, jak zmiana upodobań, gustów i preferencjach klientów czy niestabilność makrootoczenia (Malik i Niemczyk, 2016).

O roli innowacji w rozwoju przedsiębiorstw i budowaniu ich pozycji konkurencyjnej nie trzeba już dziś nikogo specjalnie przekonywać. Coraz więcej uwagi poświęca się natomiast analizie, w jaki sposób innowacje wprowadzać w sposób efektywny i co decyduje o skłonności przedsiębiorstw do innowacyjnego działania. Jedną z konsekwencji tego typu analiz jest dostrzeżenie roli, jaką w organizacji odgrywa kapitał ludzki.

Kapitał ludzki jako składowa kapitału intelektualnego stanowi ważną część zasobów przedsiębiorstwa - jego niematerialnych aktywów. Rola człowieka w procesie innowacyjności bywa niedoceniana, a w nowoczesnej organizacji to właśnie człowiek zajmuje ważne miejsce. Ludzka kreatywność jest kluczowa z punktu widzenia budowania kapitału i efektywności funkcjonowania przedsiębiorstwa. Zdolności, kwalifikacje, kompetencje kapitału ludzkiego pozostają w ścisłym związku z tworzeniem innowacji przez przedsiębiorstwo. Co ciekawe, analizy związku innowacyjności z kapitałem ludzkim nie dają jednoznacznej odpowiedzi na pytanie, jakie składowe tego kapitału mają wpływ najbardziej pozytywny. Nie można zatem jednoznacznie określić, czy najważniejszy jest tu poziom wykształcenia, kompetencje, motywacje, czy inne czynniki. Jednocześnie zaobserwowano, że istnieje pozytywny związek pomiędzy innowacją organizacji a poziomem wykształcenia i doświadczeniem zawodowym kapitału ludzkiego (Czyż, 2017).

„Innowacje to chwytliwe pojęcie, którego sens tkwił w całej historii ludzkości - nie jest zatem w swej istocie wymysłem nowej ery. Przecież człowiek od zawsze odkrywał coś nowego, oryginalnego, co było użyteczne, co można było zastosować” (Tutaj, 2019, s. 11). Innowacje odnoszą się do odkrycia i wdrożenia nowego sposobu działania: rezultatu, produktu, procesu, technologii, ale także organizacji czy społeczeństwa. Innowacyjność to $\mathrm{z}$ kolei zdolność organizacji do poszukiwania i wrażania innowacji (Tutaj, 2019). Należy jednak zauważyć, że o innowacyjności przedsiębiorstw nie decyduje wiedza i tworzenie wiedzy. Kluczowe są zachowania innowacyjne: innowacyjny produkt, innowacyjny proces, zachęcanie do innowacyjności (Czyż, 2017).

Innowacyjność można odnosić zarówno do pojedynczych podmiotów - przedsiębiorstw czy organizacji, jak i regionów czy nawet całych gospodarek. To sprawia, że zasadne jest analizowanie tego pojęcia na wielu różnych poziomach. Innowacje odgrywają niezwykle istotną rolę w tworzeniu wzrostu gospodarczego, dlatego też działania wspierające innowacyjność na szeroką skalę są podejmowane przez rządy poszczególnych krajów czy organizacje międzynarodowe, stanowią też ważny element polityki i priorytet w Unii Europejskiej (Mucha, 2019). 
Innowacyjność stanowi jeden z najistotniejszych czynników wzrostu gospodarczego, a innowacje umożliwiają tworzenie i wdrażanie skutecznych, sprawnych i efektywnych modeli biznesowych (Malara, Hrydziuszko i Ziembicki, 2015). Innowacja jest zatem źródłem postępu. Wyróżniamy innowacje pierwotne - rozwiązania nowe w skali świata, a także innowacje wtórne - wdrożone już w innych miejscach. Stąd pojęcia dyfuzji innowacji, adaptacji innowacji czy imitacji innowacji.

Należy także zwrócić uwagę na wzajemne powiązania wybranych sektorów gospodarki i grup podmiotów. Etzkowitz i Leydesdorff wyróżniają trzy podstawowe rodzaje relacji pomiędzy administracją publiczną, nauką i sferą biznesu. Model wzajemnego oddziaływania tych trzech sfer jest nazywany modelem potrójnej helisy - analiza modelu potrójnej helisy jest przeprowadzana $\mathrm{z}$ wykorzystaniem teorii pola z fizyki (Bednarzewska, 2016, za: Etzkowitz i Leydesdorff, 2000).

Należy także mieć na uwadze, że dana innowacja odbywa się w czasie. To, co jeszcze kilkadziesiąt czy nawet kilkanaście lat temu pozostawało innowacją, po upowszechnieniu przestaje nią być. Jako przykład z obszaru infrastruktury posłużyć mogą chociażby obiekty obsługi podróżnych. Kiedy w Poznaniu oddawano do użytku kolejowy Dworzec Letni, za luksus uznawano wykończenie panelami z drewna dębowego, kryształowe lustra czy żyrandol z elektrycznym oświetleniem, a za innowacyjne uznawano wówczas centralne ogrzewanie podłogowe czy drewniane żaluzje (Bielawska-Pałczyńska, 2013).

Jednym $\mathrm{z}$ ważnych pojęć towarzyszących innowacji jest dyfuzja innowacji. Jest to jeden $z$ etapów procesu innowacyjnego definiowanego jako ciąg powiązanych ze sobą działań prowadzących do urzeczywistniania pomysłów i idei. Dyfuzja oznacza, że innowacja o charakterze indywidualnym staje się powszechna z uwagi na rozszerzenie zakresu zastosowania (Tuziak, 2019). Można wyróżnić dwa podstawowe rodzaje takiego przepływu, w zależności od kierunku jego realizacji. Transfer o charakterze poziomym oznacza przepływ innowacji od badań podstawowych, poprzez prace rozwojowe aż do praktyki gospodarczej. Z kolei transfer o charakterze pionowym to przepływ innowacji pomiędzy systemami gospodarczymi, od jednego do drugiego (Tuziak, 2019, za: Korenik, 2003). Wyróżnienie dwóch rodzajów dyfuzji innowacji będzie istotne dla dalszych rozważań, pozwoli bowiem analizować kierunki, w których są rozwijane systemy transportowe, i bazę dla tego rozwoju.

Czy można mierzyć innowacje i w jaki sposób to robić? Wyzwaniem pozostaje określenie granicy - co jest innowacją, a co nie jest, jaka jest złożoność innowacji, jaki jest jej cel czy rezultat. Innowacyjność to proces dynamiczny, stąd innowacyjność próbuje się niekiedy mierzyć oceną zysku, do jakiego innowacja doprowadziła. Liczba patentów także nie jest idealnym sposobem pomiaru innowacyjności, a miara innowacyjności to często pomiar względny, polegający na tworzeniu rankingów (Tutaj, 2019). 
Badani przedsiębiorcy wskazują, że najistotniejszym czynnikiem sukcesu jest wytrwałość i ciężka praca. Jako drugi wskazują innowacyjność - kluczową zarówno dla sukcesu przedsiębiorstwa, jak i długookresowego rozwoju polskiej gospodarki (Kościelniak, 2015,).

\subsection{Uwarunkowania funkcjonowania sektora publicznego}

Dobra możemy podzielić na prywatne i publiczne. Aby określić przydział danego dobra do jednej z tych dwóch grup, zwykle stawia się dwa pytania. Po pierwsze: na ile dane dobro jest przedmiotem konsumpcji, o którą się rywalizuje? Na tej podstawie możemy mówić o konsumpcji i charakterze rywalizacyjnym bądź nierywalizacyjnym - wtedy gdy spożycie dobra przez jedną osobę nie zmniejsza możliwości spożycia dobra przez drugą. Drugie pytanie to z kolei weryfikacja tzw. możliwości wykluczenia - czy możliwe jest wykluczenie kogokolwiek z konsumpcji danego dobra? Jeżeli dane dobro nie jest przedmiotem rywalizacji i nie daje możliwości wykluczenia, wówczas mowa o czystych dobrach publicznych (Stiglitz, 2013).

Dobra publiczne przyjmujące postać usług transportu publicznego są dostarczane za pośrednictwem podmiotów sektora publicznego. Istnieją prawne i organizacyjne możliwości dostarczania tych usług przez sektor prywatny, jednak w praktyce odbywa się to pod pełną kontrolą sektora publicznego. Nawet jeśli fizycznie usługę realizuje podmiot prywatny, jej organizacją (zatem i określeniem zasad funkcjonowania, odpłatności itd.) zajmuje się sektor publiczny.

Istnieją mechanizmy związane z wprowadzaniem „wykluczenia” lub też „rywalizacji” do sektora dóbr publicznych. Jest to związane z zawodnością rynku dóbr publicznych. A zawodność ta może prowadzić do zbyt małej konsumpcji czy zbyt małej podaży. Przykładem mechanizmu, który może stanowić element wykluczenia, jest wprowadzenie opłat za korzystanie z dóbr publicznych - co powszechnie jest uznawane za sprawiedliwy sposób zapewnienia przychodów pokrywających część funkcjonowania systemu dóbr publicznych - płaci ten, kto korzysta (Stiglitz, 2013).

Zależność tę można przełożyć na rynek usług transportu publicznego. Do pewnego poziomu liczba pasażerów korzystających z systemu (czy konkretnego pojazdu) może bowiem wzrastać „bezstratnie” - dodatkowi pasażerowie nie powodują pogorszenia standardu usług. Korzystający z usług współfinansują cały system, ponieważ jest on jednak także zasilany ze środków publicznych, opłata ta jest atrakcyjna i znacznie niższa, niż gdyby system miał być finansowany wyłącznie z opłat użytkowników ${ }^{\star}$. Transport publiczny w miastach i aglomeracjach jako część

* Jednocześnie pojawia się tzw. problem gapowicza - część użytkowników nie płaci za usługę, wychodząc z założenia, że dodatkowa osoba w pojeździe nie generuje dodatkowych kosztów dla całego systemu. 
sektora publicznego jest przedmiotem wzajemnych powiązań w ramach systemu dóbr publicznych i zapewniania dobrostanu społecznego. Tym samym, niezależnie od zasad rządzących rynkiem, organizujący transport publiczny stają przed koniecznością zapewnienia usług nie tylko tam, gdzie jest to rentowne, ale także tam, gdzie czysty rachunek ekonomiczny przemawiałby za nieutrzymywaniem przewozów. Na transporcie publicznym spoczywa także odpowiedzialność za zapewnienie możliwości przemieszczania się grupom użytkowników, które z uwagi na stan zdrowia czy wiek (osoby starsze, uczniowie) mają ograniczone możliwości samodzielnego organizowania sobie transportu. W skrajnej sytuacji dochodzi do uruchamiania połączeń niemalże dedykowanych tym grupom (typu linie dowozowe do szkół czy w obszary ogrodów działkowych). Połączenia te nigdy nie będą rentowne i uzasadnione ekonomicznie ze względu na wąską grupę docelową, która zwykle korzysta z prawa do przejazdów ulgowych lub bezpłatnych.

Świadczenie usług publicznych nie jest w pełni dowolne - wpływają na nie liczne ograniczenia o charakterze administracyjnym czy związane chociażby z budżetem finansów publicznych. To wpływa negatywnie na innowacyjność przedsiębiorstw - zwykle bowiem innowacje wymagają ponoszenia nakładów o charakterze inwestycyjnym, co często nie stanowi pierwszej potrzeby dla władz publicznych. Widać to doskonale na przykładach opisanych w dalszych rozdziałach monografii. Sporą część realizowanych wdrożeń stanowią te, które dotyczą pojazdów i alternatywnych źródeł napędu. Tu natomiast w ostatnich latach szeroko dostępne były zewnętrzne źródła finansowania.

Z jednej strony zatem interesariusze transportu publicznego oczekują wysokiej i rosnącej jakości, z drugiej - negatywnie odbierają chociażby zmiany cen biletów, które stanowią jeden ze sposobów zwiększania przychodów w całym systemie. Zadania publiczne są przypisane do władzy na różnych szczeblach. Na przykład jednostki samorządu odpowiadające na potrzeby i oczekiwania mieszkańców związane $\mathrm{z}$ funkcjonowaniem transportu publicznego muszą dołożyć kolejne zadania wynikające chociażby z obowiązujących przepisów prawa czy nałożonych na administrację samorządową obowiązków. A to stanowi kolejny element, który ogranicza organizowanie transportu publicznego zgodnie z mechanizmami rynkowymi.

\subsection{Uwarunkowania funkcjonowania transportu publicznego a pandemia}

Specyfikę funkcjonowania usługi publicznej związanej z transportem zbiorowym można doskonale obserwować od marca 2020 roku, kiedy to nastąpiły gwałtowne zmiany w sposobie funkcjonowania usługi transportu publicznego będące następstwem pandemii COVID-19. 
Pandemia bardzo mocno wpłynęła na usługi transportu publicznego. Z dnia na dzień dotychczasowe założenia dotyczące sposobu organizacji tego transportu stały się nieaktualne. Limity dotyczące liczby przewożonych pasażerów znacznie zmniejszyły maksymalną pojemność środków transportu, co w połączeniu z gwałtownie obniżonym popytem na przewozy spowodowało znaczne zachwianie pomiędzy popytem a podażą. Część pojazdów komunikacji publicznej zaczęła kursować pusta, inne (wskutek ograniczeń liczby kursów, limitów dotyczących pasażerów i utrzymania części popytu wskutek braku pracy zdalnej w niektórych sektorach gospodarki) kursowały przeładowane.

Na zjawisko to należy spojrzeć także z perspektywy ekonomicznej. Zasadniczo znacznie zmniejszyła się liczba podróżnych, zmniejszyły się zatem przychody z tytułu sprzedanych biletów (najpierw krótko-, a później długookresowych). Wzrosły koszty funkcjonowania transportu w przeliczeniu na przewiezionego pasażera $\mathrm{z}$ powodu konieczności ograniczenia liczby osób w pojazdach czy generalnie mniejszej efektywności przewozów. Uogólniając: spadły co prawda koszty paliw (gdyż część pojazdów nie wyjechała na trasy), nie spadły natomiast koszty pracy stanowiące de facto koszt stały, a wzrosły koszty utrzymania taboru - chociażby w zakresie sprzątania czy dezynfekcji.

Patrząc na transport publiczny w epoce pandemii z punktu widzenia wyzwań i innowacji, już dziś można dostrzec kilka trendów. Podobnie jak w innych sektorach gospodarki możliwe stało się szersze cyfryzowanie procesów - we wszystkich obszarach wymagających interakcji, chociażby pomiędzy organizatorem i operatorem transportu a pasażerem. Rozluźniło to także wybrane procedury administracyjne poprzez dostępność do narzędzi zdalnej komunikacji i chęć ograniczania kontaktów osobistych, co często wpływa korzystnie także na szybkość podejmowania decyzji. $\mathrm{Z}$ drugiej strony pojawiła się obawa społeczna (podsycana przez media, często bez wskazywania jakichkolwiek podstaw o naukowym charakterze) związana z możliwością zakażenia poprzez przebywanie w miejscach publicznych, w tym w środkach transportu publicznego. Długofalowo zmiana sposobu postrzegania transportu publicznego może doprowadzić do upowszechnienia rozwiązań o charakterze innowacyjnym, poprawiających warunki podróżowania w transporcie publicznym (na przykład urządzenia do filtracji powietrza) czy minimalizujących interakcje ludzi (bezdotykowe systemy płatności, dystrybucja biletów i komunikacja z wykorzystaniem narzędzi elektronicznych itp.). 


\section{INNOWACJE W ZARZACDZANIU PRZEDSIĘBIORSTWEM TRANSPORTOWYM}

\section{1. Źródła innowacji}

Historia świata to historia długiej listy wynalazków - w tym tych, które zrewolucjonizowały transport. Wynalezienie koła, konnego zaprzęgu, pojazd, którym wzbili się w powietrze bracia Wright, czy lokomotywa Stephensona - każdy z tych wynalazków był wyjątkowy, zmieniał możliwości, wytyczał trendy na przyszłość. Każdy z tych wynalazków był innowacją. Na liście tej nie brakuje inżynierskich, technicznych, a niekiedy ekonomicznych porażek - warto wspomnieć historie „niezatapialnego" Titanica, wypełnionych łatwopalnym materiałem zeppelinów czy ponaddźwiękowych samolotów Concorde. Historia transportu to długie pasmo innowacji - zarówno w transporcie ogółem, jak i (jeszcze intensywniej) w specjalistycznym miejskim transporcie publicznym.

Intensywne procesy industrializacji w XIX wieku spowodowały gwałtowny wzrost zainteresowania problematyką zagospodarowania przestrzeni - lokalizacji, układów lokalizacyjnych, rozwoju miast i ich ekonomicznego zagospodarowania, a także badań z zakresu osadnictwa. To spowodowało rozwój teorii regionalnych, a wśród nich pojawiła się między innymi teoria rozwoju niezrównoważonego. Koncepcja bieguna wzrostu zapoczątkowana przez Perrouxa miała wiele wspólnego z schumpeterowską teorią innowacji. Zwrócono wówczas uwagę na uznawany dziś za klasyczny podział na inwencje (inventions), innowacje (innovations) i naśladownictwo (imitations) (Pięta, 2002).

Innowacje transportowe wywarły duży wpływ na formowanie się miast. W połączeniu z rozwojem miast tworzą efekty syntezy potrzeb i technologii dopasowane do skali i różnych potrzeb ośrodków miejskich (Giannopoulos i Curde, 2007).

Z licznych innowacji transportowych, jakie pojawiły się chociażby na przestrzeni ostatniego stulecia, jedynie bardzo niewielka część została wprowadzona - $z$ wielu zrezygnowano ze względu na koszty bądź problemy $\mathrm{z}$ wdrożeniem $\mathrm{z}$ wdrożeniem (Feitelson i Salomon, 2004).

Rozwój komunikacji publicznej i związana z nim działalność innowacyjna nieodłącznie zależą od postępu technicznego i rozwoju techniki w ogóle. I podobnie jak historia techniki pełne są ślepych zaułków i rozwiązań, które choć obiecujące, 
szybko odeszły do przeszłości. Jako przykład warto tu wspomnieć innowacje z końca XIX wieku i początku XX wieku związane z eksploatacją tramwajów o napędzie gazowym i parowym.

Jedynym miastem na terenie ziem polskich, które eksploatowało tramwaje o napędzie gazowym, była Jelenia Góra. Działania związane z budową linii tramwajowej rozpoczęto w 1895 roku, dwa lata później uruchamiając regularną linię tramwajową - $\mathrm{z}$ dworca kolejowego do Sobieszowa i koszar. Dwukierunkowe wagony silnikowe posiadały silnik gazowo-powietrzny zamontowany pod pudłem wagonu. Zbiorniki na gaz świetlny ${ }^{\star}$ umieszczono pod pomostami i pod siedzeniami, a zbiornik wody chłodzącej silnik - na dachu. Eksploatacja wagonów była problematyczna - napęd był zbyt słaby na górski teren, a konstrukcja - awaryjna i droga w eksploatacji. Tramwaje gazowe przetrwały w Jeleniej Górze zaledwie dwa lata i były zastąpione napędem elektrycznym (Lubka i Stiasny, 2004).

Podobnie niszową innowacją było zastosowanie tramwaju o napędzie parowym. Debiut tego rozwiązania to rok 1894 - linia o łącznej długości $34,5 \mathrm{~km}$ i rozstawie szyn $785 \mathrm{~mm}$ połączyła Piekary Śląskie i Gliwice (przez Bytom i Zabrze). I choć eksploatacja tramwaju parowego szybko okazała się uciążliwa dla mieszkańców, dwa lata później rozpoczęto eksploatację kolejnych linii. Tramwaje parowe przetrwały na Śląsku do 1901 roku. Półtorej dekady później (w 1916 roku) taką samą trakcję zastosowano na łódzkich tramwajowych trasach podmiejskich do Rzgowa, Tuszyna oraz ze Zgierza do Ozorkowa. Kursowały też jednak „tradycyjne” wąskotorowe parowozy, aż do elektryfikacji linii w latach 1926-1927 roku (Lubka i Stiasny, 2004).

Przez ponad 200 lat rozwoju teorii ekonomii skupiano się na dwóch czynnikach produkcji: pracy i kapitale. Wiedza, postęp techniczny czy kapitał ludzki były traktowane jako czynniki zewnętrzne, nieobjaśniane przez teorię. Dopiero teoria nowego wzrostu (za jej twórcę uznaje się Romera) wprowadziła modele, w których ważnym elementem był postęp techniczny, a wiedza - ogniwem wzrostu i elementem kapitału (Florczak, 2009).

Istnieje wiele źródeł innowacji. Mogą nimi być chociażby:

- uwarunkowania prawne - obowiązek wprowadzania bardziej ekologicznych rozwiązań w transporcie sprawia, że pojawia się wiele nowych rozwiązań technicznych i organizacyjnych w tym zakresie;

- oczekiwania mieszkańców - prowadzą do podniesienia jakości usług, nowych usług czy powstawania nowych produktów;

- rozwój miasta - zmieniające się i nowe potrzeby wymuszają zmiany.

* Gaz świetlny, inaczej gaz miejski - wykorzystywany do celów komunalnych i przemysłowych, otrzymywany $z$ różnych surowców energetycznych (między innymi gaz koksowniczy czy mieszanina gazów różnego pochodzenia). 
Jedną z przyczyn wprowadzania innowacji mogą być kwestie zrównoważonego rozwoju. Powszechnie przyjmuje się, że rozwój gospodarczy i cywilizacyjny sprzyja zwiększaniu obciążenia środowiska działalnością człowieka. Tym samym konieczne jest wprowadzanie nowych rozwiązań, które pozwolą wpływ ten zrównoważyć. To jedno ze źródeł tworzenia innowacji o prośrodowiskowym charakterze.

Problemy środowiskowe $\mathrm{w}$ wielu krajach stają się niezwykle pilne. Zmiany w konsumpcji i zwyczajach konsumpcyjnych to jak się okazuje zbyt mało, by przynieść wyraźną redukcję zanieczyszczeń różnych typów. Stąd tak duża nadzieja w zmianach o charakterze technologicznym, które mają potencjał przynosić korzyści środowiskowe w dłuższej perspektywie czasu (Geerlings, Nijkamp i Rietveld, 1997).

Z rozwojem zrównoważonym można łączyć innowacje dotyczące zarządzania, innowacje technologiczne oraz innowacje o charakterze ekologicznym (Gajda i Bajdur, 2016).

\subsection{Nowoczesne zarządzanie jako źródło innowacji}

Jednym z wyzwań gospodarki rynkowej jest transformacja sposobu funkcjonowania administracji (zarówno na poziomie rządowym, jak i samorządowym). Transformacja ta jest ważnym elementem sektora publicznego. Wraz z nią pojawia się pojęcie nowego zarządzania publicznego (new public management) oznaczającego całokształt procesów związanych z wprowadzaniem menedżerskiego podejścia do organizacji publicznych.

Wśród przyczyn wdrażania nowych koncepcji zarządczych w sektorze finansów publicznych wskazuje się między innymi rozrost sektora publicznego, kryzys wartości związanych z tradycyjnym pojmowaniem administracji publicznej oraz kryzys gospodarczy czy polityczny. Trend ten pojawił się w krajach rozwiniętych, gdzie wraz z pogorszeniem się sytuacji gospodarczej w poprawie funkcjonowania administracji publicznej upatrywano oszczędności, przy utrzymaniu wymaganego poziomu jakości usług publicznych i związanego z nimi poziomu dobrobytu (Zawicki, 2013).

Zasadniczą myślą koncepcji NPM jest przedkładanie zarządzania nad administrowaniem. Oznacza to stawianie na pierwszym miejscu wyników i ich analizy zamiast procedur i zasad biurokratycznych. Tym samym zwiększa się nacisk na jakość usług publicznych, potrzeby i oczekiwania ich odbiorców (Młodzik, 2015). W rozwoju modeli zarządzania publicznego można wskazać cztery etapy - po państwie prawa i modelu idealnej biurokracji pojawiła się koncepcja nowego zarządzania publicznego czy wręcz partycypacyjnego zarządzania publicznego, w któ- 
rym podstawowym elementem staje się interakcja administracji z interesariuszami (Szumowski, 2014).

Kształt współczesnej administracji to w sporej części efekt modelu idealnej biurokracji Webera. Niemiecki socjolog przedstawiał wizję sprawnie działającego państwa, opartego na sformalizowanym podejściu, procedurach, dyscyplinie i kontroli nad realizowanymi zadaniami (Oramus, 2015, za: Weber, 2002). Przeciwieństwem tej koncepcji jest coraz częściej akcentowane podejście typu governance (public governance). Zakłada ona, że istnieje odpowiedzialność decydenta względem interesariuszy, a dla dobra ogółu działania urzędnicze powinny być konsultowane ze wszystkimi zainteresowanymi (Oramus, 2015, za: Peters, 2010).

Podejścia new public management i public governance mocno wpływają na kształt oferty transportu publicznego. Dzięki menedżerskiemu nastawieniu na cele i wyniki możliwa jest poprawa efektywności realizowanych procesów - zarówno w odniesieniu do procesów o charakterze administracyjnym, jak i związanych z realizowanymi przewozami. Z kolei wzrost znaczenia kompetencji menedżerskich u zarządzających systemami transportu publicznego prowadzi do skrócenia procesu decyzyjnego, poprawy jakości decyzji i ukierunkowania ich na jakość świadczonych usług. Transport publiczny jako element dynamicznej tkanki miejskiej musi być efektywnie zarządzany, by sprostać potrzebom użytkowników i stanowić atrakcyjną alternatywę dla motoryzacji indywidualnej - a nowoczesne zarządzanie pozwala tę efektywność podnosić.

Dodatkowo, dzięki koncepcjom typu public governance, coraz bardziej popularne staje się angażowanie poszczególnych grup interesariuszy. Przybiera ono rozmaite formy: konsultacji społecznych, otwartych dyskusji z udziałem chociażby rad osiedli czy mieszkańców, zbieranie przez operatorów i organizatorów wniosków od interesariuszy i ich analiza. Takim działaniem jest też komunikowanie przez organizatora transportu planów rozwoju sieci komunikacyjnej (w tym strategii czy planów długofalowych), co sprzyja dyskusji na temat kształtu oferty usług transportu publicznego. Tym samym nowoczesne modele zarządzania $\mathrm{w}$ transporcie publicznym można z powodzeniem uznać za jedno z narzędzi o charakterze innowacyjnym.

\subsection{Integracja środków transportu jako innowacja}

Integracja systemów transportowych pozostaje jednym z najważniejszych wyzwań dla zarządzających transportem publicznym. W przypadku miejskiego transportu publicznego ma ona potencjał przede wszystkim w zakresie integracji komunikacji miejskiej z podmiejską, miejskiej z gminną czy miejskiej z podmiejską/gminną i regionalną - autobusowej czy kolejowej. Potencjał ten ujawnia się także w integracji transportu publicznego $\mathrm{z}$ indywidualnym (rysunek 2.1). 


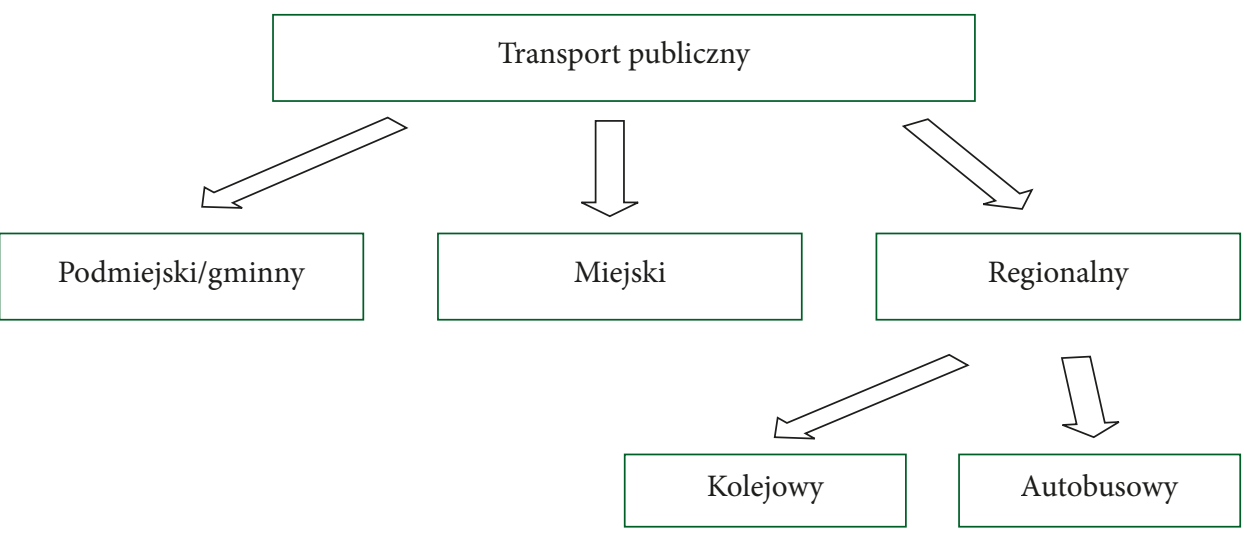

\section{Rysunek 2.1. Potencjał integracji systemów transportu publicznego}

Mając na uwadze ograniczenia możliwości rozwijania efektywnie funkcjonującego systemu transportu publicznego w obszarach o niższej gęstości zabudowy, a także przestrzenny rozwój miast, aglomeracji i ich „rozlewanie się”» na okoliczne tereny, coraz większą rolę odgrywa i będzie odgrywać wzajemna integracja różnych środków transportu - nie tylko wchodzących w skład zorganizowanego transportu publicznego. Dotyczy to różnych form transportu organizowanego publicznie, ale wykorzystywanego indywidualnie, wskazanych na rysunku 2.2.

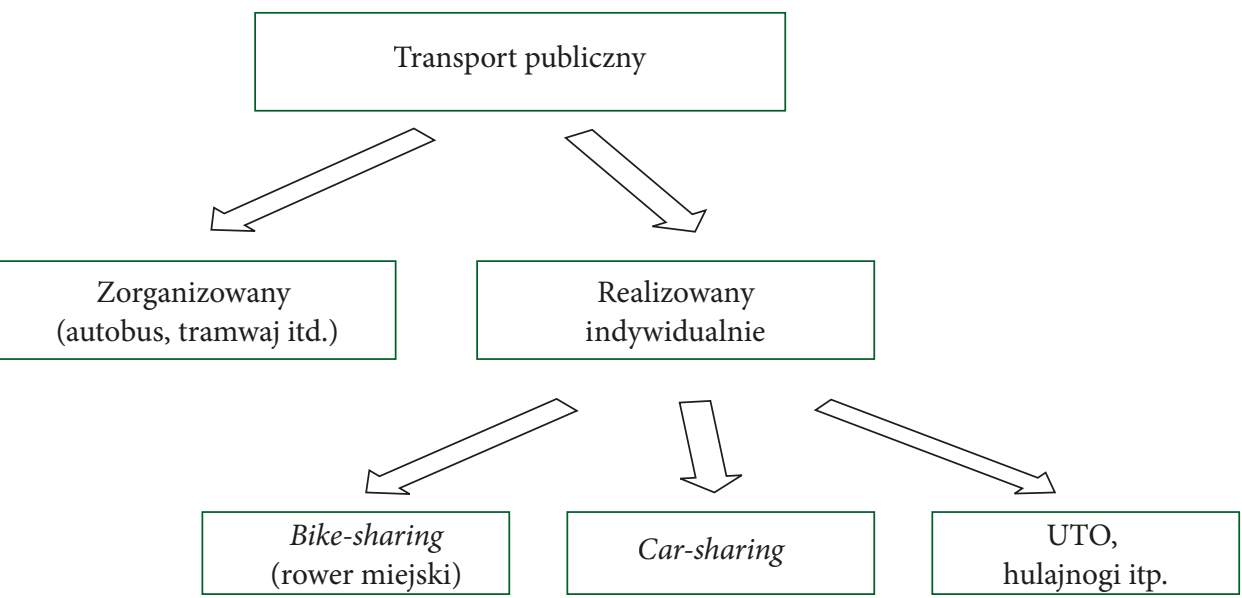

Rysunek 2.2. Potencjał integracji systemów transportu publicznego II

* Pojęcie „rozlewania się miast” (urban sprawl) oznacza nieskoordynowany rozwój ośrodków miejskich i ich przedmieść. 
Wzajemne integrowanie środków transportu publicznego oraz komunikacji publicznej z indywidualną wymaga odpowiedniego zarządzania na co najmniej dwóch podstawowych płaszczyznach związanych z:

- tworzeniem infrastruktury węzłów przesiadkowych,

- zarządzaniem informacją.

W kontekście systemów informatycznych daje to potencjał tworzenia i wykorzystywania narzędzi służących w szczególności do:

- zarządzania dynamiczną informacją pasażerską - także w celu wspierania przesiadek w punktach węzłowych, na styku różnych środków i form transportu;

- zarządzania ruchem pojazdów - także w celu uprawnienia przesiadek na styku różnych środków i form transportu;

- zarządzania informacją o dostępności pojazdów / środków transportu - w przypadku chociażby car-sharingu i UTO;

- zarządzania taryfami i odpłatnością za korzystanie z usług - indywidualnie dla poszczególnych środków i form transportu lub w sposób zintegrowany w przypadku integracji taryfowej.

Wspomniane wyżej zagadnienia to obecnie jeden $\mathrm{z}$ bardziej złożonych problemów w informatyzacji transportu publicznego. Istnieje tu bowiem konieczność integracji systemów informatycznych wykorzystywanych przez różnych operatorów, organizatorów, środki transportu. Rodzi to wiele wyzwań zarówno organizacyjnych, jak i technicznych czy informatycznych.

Jednym z powszechnie stosowanych rozwiązań jest integracja taryfowa - pozwalająca na tworzenie wspólnego biletu w ramach komunikacji miejskiej i podmiejskiej czy miejskiej i kolejowej. Rozwiązanie to stanowi standard w krajach zachodnich, $\mathrm{w}$ Polsce od kilku lat także jest mocno rozwijane $\mathrm{z}$ wieloma sukcesami.

Podejmowane są również pierwsze próby rozwiązywania wyzwań związanych ze skomunikowaniem przesiadek czy integracją systemów dynamicznej informacji pasażerskiej - tutaj wskazać można dobre praktyki w ramach działań jednego organizatora, znacznie trudniej jednak o integrację pomiędzy organizatorami (na przykład na styku: organizator transportu publicznego w mieście lub aglomeracji i regionalny operator kolejowy).

\subsection{Innowacja w przedsiębiorstwie a rozpowszechnienie innowacji}

Innowacje w organizacji można analizować w różnych kontekstach i perspektywach. Jednym z elementów jest sam proces innowacyjny, innym - podmioty biorące udział 
w tym procesie (osoby, przedsiębiorstwa, organizacje, sieci). Można analizować rolę instytucji na poziomie regionalnym, krajowym czy międzynarodowym, a także interakcje pomiędzy uczestnikami procesów innowacyjnych. No i jest jeszcze kwestia konsekwencji wdrażania innowacji na różnych płaszczyznach: społecznej, ekonomicznej, technologicznej czy politycznej (Kozioł-Nadolna i Suchocka, 2020).

Innowacyjność odnosi się do różnych obszarów działania przedsiębiorstwa. Co ważne, sam fakt bycia przedsiębiorcą jest często utożsamiany $\mathrm{z}$ innowacyjną postawą. Przedsiębiorstwo jest zatem skazane na bycia innowacyjnym, a funkcja rozwoju technicznego jest traktowana priorytetowo. Podkreśla się tu dostarczanie produktów i usług nie tylko „na dziš”, ale także na przyszłość - co wymaga modernizacji zasobów, technologii, struktury oraz relacji z otoczeniem (Markiewicz, Bielawa i Tylżanowski, 2020).

Należy także zwrócić uwagę na rozbieżności dotyczące źródła wzrostu według różnych teorii. O ile w tzw. teorii neoklasycznej przyjmuje się, że wzrost gospodarczy zależy całkowicie od zmian technologicznych o charakterze zewnętrznym, o tyle w teorii wzrostu endogenicznego ważne są zmienne o charakterze wewnętrznym stąd inwestycje w kapitał ludzki i techniczny (Domański, 2006).

W teorii ekonomii wspomina się także o ekonomii ewolucyjnej - nawiązując między innymi do Darwina, w której zakłada się, że rozwój wynika z ewolucyjnego (a nie rewolucyjnego) podejścia. Źródłem tej teorii jest przyroda, gdzie gatunki i organizmy ewolucyjne przystosowują się do otoczenia. Teoria ta znalazła potwierdzenie między innymi w mikroekonomii (mniej w makroekonomii).

Z kolei ekonomia ewolucyjna ma swoją kontrteorię twórczej destrukcji. Za twórcę wyrażenia „twórczej destrukcji” uznaje się wspomnianego już wcześniej Schumpetera. Zakłada się, że źródłem twórczej destrukcji jest siła nowego wynalazku. Aby stworzyć coś nowego, należy najpierw coś innego zniszczyć (Stępnicka, 2013).

Zauważmy, że różne przedsiębiorstwa transportu publicznego mają różny potencjał wdrażania i przyswajania innowacji. W pierwszym rozdziale wskazano wiele różnych kontekstów i definicji innowacji. W drugim stwierdza się osadzenie tych innowacji w kontekście przedsiębiorstw transportu publicznego. O potencjalne wdrażania innowacji decyduje wiele czynników - zasoby finansowe, możliwości organizacyjne, stopień niezależności i decyzyjności kadry menedżerskiej. W zależności od ogólnego poziomu rozwoju przedsiębiorstwa te same rozwiązania mogą być uznane za innowacyjne i realne bądź też za niemożliwe do wdrożenia. Na rynku można wskazać na przykład kilku dużych operatorów tramwajowych czy autobusowych wyznaczających trendy w zakresie inwestycji w pojazdy i innowacji taborowych czy informatycznych. Za nimi podążają kolejni, w miarę posiadanych możliwości i budżetów.

Istnieje wiele grup czynników mogących ograniczać innowacyjność przedsiębiorstw. Analiza literatury przedmiotu pozwala wyróżnić kilka podstawowych rodzajów barier: rynkowe, finansowe, związane z polityką, produkcją czy dostępem 
do informacji. Bariery te wpływają na niską innowacyjność zwłaszcza w obszarze małych i średnich przedsiębiorstw, co sprawia, że nie są one w stanie konkurować $\mathrm{z}$ innymi podmiotami $\mathrm{z}$ tego sektora na rynku globalnym (Leśna-Wierszołowicz, 2016).

Jakie bariery pojawiają się we wdrażaniu innowacji? Innowacje są traktowane często jako cel sam w sobie, a nie środek do osiągania innych celów natury gospodarczej. Zamiast osiągać cele, wprowadza się innowacje. Z badań wynika, że największy wzrost PKB na mieszkańca nie jest obserwowany w krajach najbardziej innowacyjnych. A sama innowacyjność powinna być traktowana jako droga do celu, jako sposób na bycie konkurencyjnym (Ludwiczak, 2016). Dodatkowym ograniczeniem jest to, że nie zawsze możliwa jest skuteczna konwersja wdrożenia pilotażowego w rzeczywisty projekt, zwłaszcza gdy jest on realizowany $\mathrm{w}$ ramach partnerstwa publiczno-prywatnego (Smith, Sochor i Karlsson, 2019).

\subsection{Innowacje jako katalizator rozwoju przedsiębiorstwa}

Innowacja $\mathrm{z}$ założenia jest takim działaniem, które cechuje z jednej strony nowatorstwo (efekt nowości), a z drugiej celowość i świadomość - aby projekt inicjalizować i wprowadzać w życie. Taka definicja wyraźnie wskazuje na konieczność systemowego podejścia do tematu innowacji - zarówno ich wprowadzania, jak i zarządzania nimi (Porada-Rochoń, Brojak-Trzaskowska, Kordela i Tomczyk, 2018). Kluczową kwestią jest zidentyfikowanie możliwości nawiązywania współpracy - to współdziałanie gospodarcze jest bowiem źródłem efektów synergii - na przykład w efekcie kooperacji naukowo-biznesowej. Konieczna jest identyfikacja atutów, ale i słabych stron współdziałania, zidentyfikowania strategicznych zasobów i procesów organizacji, a także ocena, na ile organizacja ma potencjał i środki (finansowe, intelektualne i inne) do realizacji celów (Porada-Rochoń i in., 2018).

Z założenia innowacja powinna prowadzić do rozwoju przedsiębiorstwa. Rozwój ten może przybierać różne formy. Przykładem są systemy informatyczne. Ich wdrażanie zwykle podnosi poziom informatyzacji procesów, sprzyja digitalizacji procesów czy eliminacji dokumentów papierowych. Aby to jednak nastąpiło, musi być „wola” rozwoju organizacji. W przeciwnym razie pojawi się wprawdzie innowacja pod postacią na przykład wdrożonego systemu informatycznego (o ile oczywiście będzie on się kwalifikował do uznania go za innowację), jednak nie będzie można mówić o innowacji organizacyjnej czy procesowej.

Innowacja może być także katalizatorem rozwoju. Przykładowo: zakup autobusów z napędem alternatywnym prowadzi do konieczności modernizacji obiektów zajezdni, wdrożenia systemów informatycznych do zarządzania autobusami i ich 
ładowaniem, szkolenia personelu w zakresie obsługi technicznej skomplikowanych pojazdów. Zgodnie z tym, co napisano wcześniej, wdrożenie systemu informatycznego prowadzi też do informatyzacji procesów i przyspiesza rozwój procesów w organizacji.

Współczesna gospodarka mierzy się z wieloma wyzwaniami. Zmiany modeli biznesowych i sposobu funkcjonowania przedsiębiorstw na rynku mogą doskonale współgrać ze strategią innowacyjności. Tym samym innowacyjność można połączyć z nowymi koncepcjami tworzenia wartości: logiką usługową czy „wartości w użyciu”.

Logika usługowa zakłada, że podstawą funkcjonowania w gospodarce jest usługa, a rola zaznaczonych już na początku ról (na przykład dostawców/odbiorców) ma charakter wtórny, z kolei wartości tworzone są sieciowo, przez wielu różnych aktorów w sieci. Formowanie się wartości pozostaje w korelacji $\mathrm{z}$ funkcjonującą strukturą społeczną i systemem społecznym. Z kolei koncepcja „wartość w użyciu” (value-in-use) to zestaw zasad zakładających, że wartość dodana jest tworzona dla użytkownika i przedmiotem badań powinien być sposób jej wykorzystania przez użytkownika, a proces tworzenia wartości jest interaktywny - istotny jest zatem także ten proces, a nie sam efekt końcowy (Kłeczek, Pluta-Olearnik i Pukas, 2020).

Autorzy wskazują, że takie podejście jest możliwe w odniesieniu do mobilności miejskiej. Tym samym należałoby postawić pytanie: Czy takie nowoczesne formy analizy mobilności miejskiej wpływają na postrzeganie całej oferty przewozowej i zmieniają postrzeganie oferowanej usługi? Odpowiedź na to pytanie jest twierdząca, a nowe podejście do mobilności miejskiej oznacza także zmienione podejście do usług tworzonych w celu realizacji potrzeby przemieszczania się i towarzyszących im innowacji.

Same innowacje również ewoluują. Zmienność uwarunkowań kreujących strategię organizacji w czasie oznacza pojawienie się ryzyka związanego z tzw. dryfem strategicznym. Dryf strategiczny oznacza spadek dopasowania strategii do pozycji organizacji, rodzi ryzyko pogorszenia jej wyników poprzez stopniowo coraz gorsze identyfikowanie zmian w otoczeniu biznesowym. Zmiany w sektorze gospodarczym, rutynowość działania, niedostosowanie praktyki do zachodzących zmian czy zmniejszenie poziomu aktywności i interakcji z otoczeniem - to wszystko może prowadzić do pojawienia się dryfu strategicznego (Polinkevych, 2018). Pojęcie to można przenieść także na politykę innowacyjną przedsiębiorstwa - z czasem innowacje mogą się okazać mniej przystające do organizacji, jej otoczenia, warunków rynkowych. Tym samym konieczność prowadzenia aktywnej polityki innowacyjnej i innowacyjnego działania pozostaje cały czas aktualna.

Zasadniczo innowacje są wskazywane jako czynnik rozwoju społeczno-ekonomicznego, ale także siła napędowa gospodarki, wymóg współczesnego postępu cywilizacyjnego. Sukces w zakresie innowacyjności jest determinowany kilkoma warunkami: zakresem wykorzystywania nowych pomysłów, ich wykonywalnością, uzasadnieniem ekonomicznym, orientacją na klienta czy proinnowacyjnym klimatem wewnątrz organizacji (Janasz i Wiśniewska, 2017). 
Należy zauważyć, że w literaturze przedmiotu pojawia się także pojęcie strategii innowacji - ma ona oznaczać kompleksowe podejście do tematu innowacyjności i zarządzania organizacją, zapewnić integrację celów biznesowych i innowacyjnych. To z kolei ma zapewnić kompromis pomiędzy bieżącą działalnością przedsiębiorstwa a jego strategią rozwoju (Pieniacka, 2016).

Zależność pomiędzy wzrostem gospodarczym a działalnością innowacyjną jest dziś częstym obszarem badań. Temat ten analizował już Adam Smith. Od XVIII wieku związki między innowacyjnością a wzrostem gospodarczym były rozpatrywane „intuicyjnie, formalnie innowację wprowadzono do modeli wzrostu gospodarczego w 1957 roku, a udział przedsiębiorstw prowadzących działalność innowacyjną uznaje się za jeden z wyznaczników poziomu innowacyjności całego kraju" (Ludwiczak, 2016).

Badania prowadzone przez GUS potwierdzają znaczenie klientów w procesie kreowania czy też wdrażania innowacji. Innowacja zorientowana na klienta i użytkownika (user-driven information) polega na korzystaniu z wiedzy użytkowników - zarówno klientów indywidualnych, jak i przedsiębiorstw czy organizacji. Użytkownicy mają swoje potrzeby, mogą zgłaszać pomysły, koncepcje i rozwiązania, które mogą być źródłem innowacji (Żelichowska i Lis, 2015).

\subsection{Działalność innowacyjna w sektorze usług publicznych}

Jedną z cech współczesnych gospodarek (zwłaszcza tych wysoko rozwiniętych) jest wysoki udział usług przy zmniejszonym udziale produkcji materialnej. Rozwój sektora usługowego oznacza także rozwój tworzenia wartości dodanej - usługi mają bowiem zdolność do szybkiego przyjmowania nowych rozwiązań technicznych czy technologicznych. Rozwój technologiczny usług sprawia, że coraz częściej mowa jest dziś nawet o „gospodarce usług” (Szukalski, 2018).

Chcąc analizować tematykę usług, należy rozpocząć rozważania od syntezy: czym usługi są i jakie zawierają cechy. Jako produkt rynkowy usługi charakteryzują się:

- istotną rolą czynnika ludzkiego,

- nietrwałym i niematerialnym charakterem (co też wyklucza możliwość magazynowania),

- krótkim czasem od pomysłu do wdrożenia,

- zróżnicowanym poziomem zaangażowania technologicznego,

- procesowym charakterem usługi świadczonej w określonym czasie i przestrzeni, 
- nieostrym rozróżnieniem pomiędzy procesem usługowym a produktem usługi (Dudzińska-Korczak, 2017).

Usługi zawsze były istotnym elementem działalności człowieka. Ostatnie dwie dekady XX wieku to jednak gwałtowny rozwój gospodarki usługowej w krajach rozwijających się i rozwiniętych, między innymi dzięki postępowi naukowo-technologicznemu, liberalizacji gospodarki i globalizacji rynków. Usługi są niezbędne do zaspokajania ludzkich potrzeb, a przedsiębiorstwa świadczą je w sposób profesjonalny i wydajny - wykorzystując korzyści skali (Gąsiorkiewicz, Sitarski, Sobolewska, Wiśniewski, 2017). W związku z tym coraz częściej mowa jest także o innowacjach usługowych.

Innowacje w usługach z założenia mają nieco inny charakter - należy bowiem uwzględnić naturalną odmienność usług (niematerialność, jednoczesność świadczenia usług i ich konsumpcji, niejednolitość czy nietrwałość). Nie oznacza to, że usługi nie mogą podlegać procesom innowacyjnym, a w wybranych subsektorach możliwości w tym zakresie są większe niż w sferze produkcji materialnej. Innowacja w usługach nie zawsze jest bezpośrednio widoczna. Może ona oznaczać między innymi nową płaszczyznę współpracy między organizacjami (usługodawcą i usługobiorcą) czy też nowy kształt relacji między nimi. Innowacją w usługach może być także narzędzie wspierające świadczenie usługi - chociażby w zakresie informatyki czy technologii rewolucjonizujących świadczenie usług (Szukalski, 2018).

Wielu autorów bezpośrednio łączy innowacyjność z przedsiębiorczością. Takie podejście nakazuje postawić pytania: Czy może istnieć przedsiębiorstwo bez innowacji? Na ile samo bycie „przedsiębiorstwem” warunkuje konieczność bycia innowacyjnym. W wielu publikacjach można odnaleźć pogląd, że przedsiębiorca z natury rzeczy musi być innowacyjny. I jest, jeżeli chce osiągnąć sukces. Ale jak odnieść do tego jednostki o charakterze publicznym? Czy i w jakim zakresie możliwa jest dziś innowacja w sektorze publicznym? Zwłaszcza że mamy to do czynienia z dwoma ciekawymi zjawiskami - innowacji w sektorze podmiotów niebędących przedsiębiorstwami* ${ }^{*}$, innowacji w sektorze usługowym.

Sektor usługowy stanowi pewne wyzwanie dla badaczy skupiających się na innowacjach. W wielu tradycyjnych wskaźnikach uwzględnia się jedynie innowacje naukowe i technologiczne, co jest przestarzałe. Współcześnie bowiem mamy do czynienia, zwłaszcza w obszarze usług, z innowacjami, których źródłem nie są działy badawczo-rozwojowe. A z punktu widzenia innowacyjności najistotniejsze są rezultaty, a nie nakłady (Węgrzyn, 2014). Ważne, aby właściwie definiować usługę publiczną. I choć nie ma tutaj jednoznacznej definicji, przyjmuje się, że usługa publiczna jest świadczona dla obywateli obsługiwane przez instytucje publiczne

* W wielu przypadkach usługi transportu publicznego są świadczone przez podmioty publiczne, które nawet jeżeli posiadają status przedsiębiorstw (na przykład spółek prawa handlowego), to nie można ich przyrównywać do przedsiębiorstw z kapitałem prawnym, których działalność nie jest warunkowania zabezpieczonym finansowaniem w postaci konkretnego strumienia przychodów. 
(lub instytucje niepubliczne w imieniu publicznych). Jest adresowana do wszystkich, w trybie ciągłym i stanowi obowiązek państwa (Brdulak, 2014).

Usług transportowa jest usługą o charakterze publicznym - w literaturze funkcjonuje także pojęcie dobra publicznego. Usługi tego typu mają kilka cech charakterystycznych. Po pierwsze - korzystanie z nich przez jedną osobę nie uniemożliwia korzystania $\mathrm{z}$ nich przez inną osobę. Po drugie - wiele osób może osiągać korzyści korzystania z usługi jednocześnie, każdy w dogodnym dla siebie terminie. Trzecim charakterystycznym elementem jest kryterium ekonomiczne (kryterium odpłatności) - dobra publiczne są finansowane $\mathrm{z}$ funduszy publicznych (Owsiak, 2005).

Różne są modele finansowania usługi publicznej i udziału konsumentów w tym finansowaniu, zwykle jednak jest to model łączony - wpływy z biletów pokrywają część opłat, ale nie zapewniają możliwości samofinansowania się systemu komunikacji publicznej. To rodzi kolejne ryzyko wdrażania innowacji. Powstaje bowiem pytanie: Czy lepiej świadczyć usługę w niższym standardzie, przy niższych kosztach, ale zapewniając większe (procentowo) finansowanie tej usługi wpływami z biletów? Czy wręcz przeciwnie, prowadzić działalność innowacyjną, podnosić jakość (ale i koszty funkcjonowania) systemu transportu publicznego, licząc na to, że konieczność finansowania przez stronę samorządową wzrośnie? Tematyka wpływu innowacji na przychodowość transportu publicznego jest tematyką stosunkowo nową. Nie można jeszcze ocenić, na ile wprowadzenie na przykład autobusów elektrycznych wpłynęło na pozytywne postrzeganie transportu publicznego i przełożyło się choćby na wzrost wpływów ze sprzedawanych biletów.

Oczywiście nie należy tutaj zakładać, że wszystkie innowacje oddziałują tak samo na system transportu publicznego - podnosząc jego jakość, ale i koszty funkcjonowania. Istnieje wiele sytuacji, w których wprowadzenie nowych rozwiązań pozwala w dłuższej perspektywie obniżyć koszty eksploatacji lub osiągać inne korzyści pośrednio oznaczające niższe koszty funkcjonowania całego systemu. Można tu wskazać przykład omawianych w rozdziale 4 paliw alternatywnych. Są wśród nich zarówno takie, które zapewniają niższe koszty eksploatacji (chociażby autobusy zasilane CNG), jak i takie, co do których nie ma wątpliwości, iż koszty paliwa i bieżącej eksploatacji będą wyższe (autobusy wodorowe).

Jednocześnie należy zauważyć, że sektor publiczny wbrew pozorom ma całkiem sporo możliwości realizowania innowacji różnymi kanałami. Należy zatem się zastanowić, na ile działalność innowacyjna pozwala wykorzystać możliwości, jakie daje dziś sektor publiczny: organizacyjne czy finansowe.

Jako „finansowanie inwestycji” uznawane są w literaturze ekonomicznej kierunki przepływu środków związane $\mathrm{z}$ ich pochodzeniem lub kreowaniem. Wskazuje się pojęcia takie jak „źródła finansowania” i „sposoby finansowania” (Gorzałczyńska-Koczkodaj i Szaja, 2013, za: Dylewski i in., 2006). W praktyce źródłem finansowania inwestycji komunalnych mogą być: 
- źródła o charakterze wewnętrznym - podatki i opłaty lokalne, inne dochody samorządu;

- źródła o charakterze zewnętrznym - zwrotne lub bezzwrotne. Źródłami o charakterze zwrotnym są między innymi wszelkie pożyczki i kredyty komercyjne, obligacje komunalne, środki od inwestorów prywatnych czy pożyczki i kredyty preferencyjne udzielane przez wybrane instytucje. Za bezzwrotne formy finansowania inwestycji można uznać wpływy z udziałów w podatkach stanowiących dochód budżetu państwa, dotacje celowe, subwencje ogólne czy środki z budżetu UE po akcesji Polski do UE (Gorzałczyńska-Koczkodaj i Szaja, 2013, za: Mackiewicz i in., 2008).

Istnieje wiele mechanizmów wspierania inwestycji w jednostkach publicznych a do popularniejszych i chętniej wykorzystywanych należą środki bezzwrotne pod postacią funduszy europejskich. I nie bez przyczyny - budżety są tu bowiem znaczne, a szeroki zakres programów pozwala dobrać źródło finansowania do realizowanego projektu. Dodatkowe środki są przyznawane wybranym obszarom i rodzajom beneficjentów - chociażby środki na rozwój wschodniej części Polski czy obszarów wiejskich.

Niezależnie od źródła finansowania inwestycji należy zwrócić uwagę na fakt, że w przypadku jednostek o charakterze publicznym zwykle występuje pewność finansowania. Stały strumień przychodów związany ze świadczeniem usługi w praktyce ułatwia prowadzenie inwestycji, a także realizowanie projektów innowacyjnych zwłaszcza w sytuacji, gdy zwrot z tych projektów następuje dopiero po kilku latach. W podmiotach świadczących usługę publiczną łatwiej także realizować innowacje nieprowadzące bezpośrednio do poprawy efektywności gospodarowania, ale służące na przykład obniżeniu wpływu na środowisko i otoczenie - wspomniana stabilność przychodów daje szersze możliwości realizowana tego typu projektów.

W przypadku transportu publicznego należy zauważyć, że innowacje można wykorzystać do wzmocnienia pozycji transportu publicznego i wprowadzenia jego nowych, atrakcyjniejszych form, na przykład nowych środków transportu, poprawienia jakości świadczonych usług, usprawnienia tych usług oraz wprowadzenia usług zupełnie nowych (przykłady takich działań wskazano w rozdziałach 3, 4 i 5).

Jak kształtuje się struktura innowacji podejmowanych przez przedsiębiorstwa usługowe? Na jakim poziomie przedsiębiorstwa realizują innowacje produktowe i procesowe oraz jak wyglądają tendencje rozwojowe? Analizując udział przedsiębiorstw innowacyjnych $\mathrm{w}$ ogólnej liczbie przedsiębiorstw usługowych w latach 2010-2015, można stwierdzić, że systematycznie malała liczba przedsiębiorstw innowacyjnych. W latach 2013-2015 najbardziej aktywne w obszarze innowacji przedsiębiorstwa $\mathrm{z}$ obszaru ubezpieczeń i reasekuracji wprowadzały innowacje produktowe $(43,3 \$)$, procesowe $(56,7 \%)$, organizacyjne $(35,8 \%)$ i marketingowe $(41,8 \%)$. Najniższe wyniki w tej statystyce odnotowywały przedsiębiorstwa zajmujące 
się handlem hurtowym oraz transportem lądowym i rurociągowym (z innowacjami produktowymi $(2,0 \%)$, procesowymi $(3,7 \%)$, organizacyjnymi $(2,7 \%)$ i marketingowymi $(2,2 \%))$. Pomimo rozwoju rynku usług w Polsce poziom innowacyjności usług jest niski i z wyraźnym trendem spadkowym (Dudzińska-Korczak, 2017).

Należy wreszcie zauważyć, że innowacyjność w sektorze publicznym warto potraktować jako szansę - $\mathrm{w}$ przeciwieństwie do sektora prywatnego nie jest on nastawiony na globalizację. I może się skupić na rozwiązywaniu problemów, angażowaniu społeczności, tworzeniu ekosystemów, przy jednoczesnym zrozumieniu dla idei konkurencyjności i innowacyjności. Należy także zwrócić uwagę na zmiany, jakie dotykają podmioty z szeroko rozumianego sektora publicznego. Niezależnie od formy organizacyjnej i prawnej stoją one przed koniecznością efektywnego gospodarowani zasobami, co niekiedy jest związane ze zmianami także w obszarze kluczowych procesów. 


\section{RYNEK TRANSPORTU PUBLICZNEGO - SPECYFIKA DZIAtALNOŚCI}

Transport publiczny jako usługa o charakterze publicznym podlega określonym prawidłowościom. Jednocześnie współczesne uwarunkowania ekonomiczne powodują, że usługi tego typu powinny być rentowne. Rynek transportu publicznego jest interesujący z kilku powodów. Sam transport publiczny funkcjonuje w powiązaniu z miastami i ich rozwojem - system transportu publicznego musi zatem korelować $\mathrm{z}$ przestrzennym rozwojem miasta i aglomeracji czy rozwojem regionalnym. $\mathrm{Z}$ drugiej strony, choć jest usługą publiczną i zwykle niedochodową, poddaje się prawidłowościom rynkowym i założeniom ekonomiki transportu. A jako podobszar logistyki miejskiej pozostaje także w zgodzie z podstawowymi założeniami i koncepcjami logistyki. Tym samym jako część systemu logistycznego, miasta, aglomeracji czy regionu stanowi interesujący obszar badań.

W monografii skupiono się na tym, co dzieje się w miastach. Skupiono się na miastach, aglomeracjach, ich cechach szczególnych. Nie oznacza to, że katalog systemów transportu publicznego zamyka się do terenów zurbanizowanych. Podobne (ale często i dodatkowe) wyzwania są związane z organizacją transportu publicznego na wyższym szczeblu - regionalnym, wojewódzkim czy krajowym.

„Badania prowadzone w miastach wojewódzkich w Polsce wskazują, że kwintesencją innowacyjności w zarządzaniu miejskim transportem publicznym są zmiany jakościowe wprowadzane na poziomie polityki transportowej" (Cichosz, 2015). Tym samym innowacyjności w publicznym transporcie zbiorowym poszukiwać należy na poziomie wzrostu jakości oferowanych usług i wzrostu poziomu zadowolenia klienta. Nie są to jednak jedyne czynniki decydujące o rozwoju transportu publicznego. W dalszych rozdziałach przedstawione zostaną wybrane przykłady - zarówno takich innowacji, które są związane z podnoszeniem jakości (w rozumieniu jakości usługi dla klienta końcowego), jak i organizacji innowacyjnych czy procesowych przekładających się na jakość końcowej usługi jedynie pośrednio.

Szczególnie ważnym problemem polskich miast pozostaje wzrastający poziom kongestii transportowej - jej koszty wewnętrzne sięgają w Polsce 6,5 mld euro, koszty zewnętrzne - 770 mln euro, co stanowi łącznie prawie $2 \%$ PKB - dwa razy więcej niż średnio w Unii Europejskiej, a koszty te generowane są w Polsce przede wszystkim na obszarach miejskich (Misiurski, 2017). 


\subsection{Błędne koło komunikacji miejskiej}

Transport publiczny pozostaje jednym z elementów decydujących o mobilności miejskiej. Oczywiście każdy z mieszkańców i użytkowników miejskiej przestrzeni ma swobodę wyboru sposobu przemieszczania się, a relacje pomiędzy możliwościami poszczególnych środków i gałęzi transportu zmieniają się. W literaturze przedmiotu powszechnie wykorzystywanym pojęciem w tym obszarze jest tzw. „błędne koło komunikacji zbiorowej” („błędne koło transportu miejskiego”). Oznacza ono wzajemne relacje pomiędzy transportem publicznym a motoryzacją indywidualną. Kształt „błędnego koła transportu miejskiego" przedstawiono na rysunku 3.1.

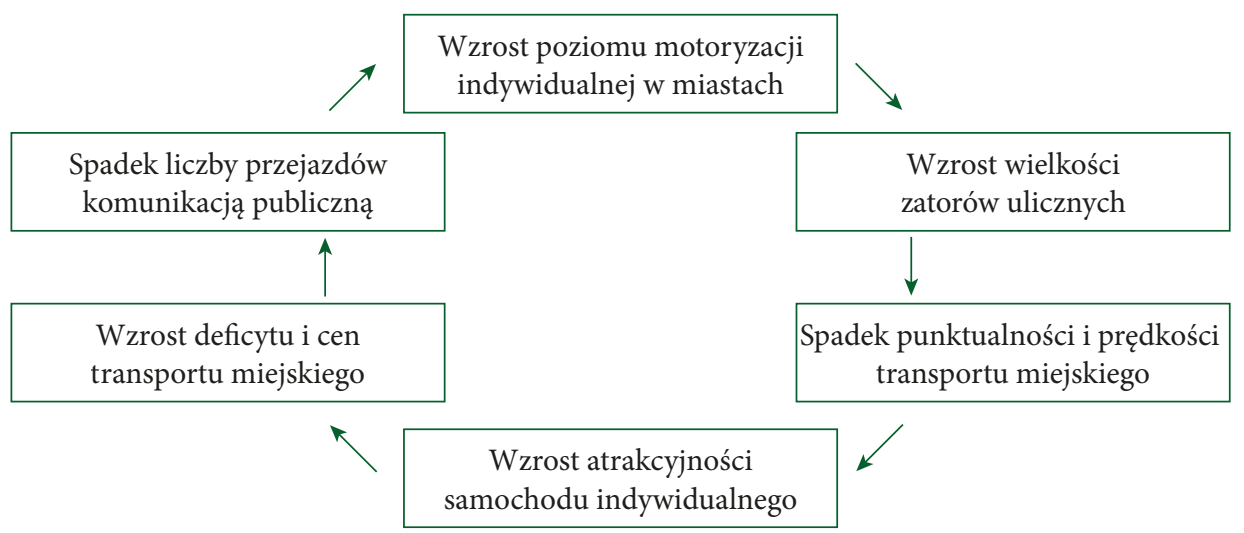

\section{Rysunek 3.1. Błędne koło transportu miejskiego}

Źródło: (Kauf, 2013, s. 58).

Wybór środka transportu jest jednym z podstawowych elementów zachowań komunikacyjnych mieszkańców. Oznacza on często de facto proces poszukiwania najlepszych możliwości przemieszczania się (Kauf, 2013).

Powyższy schemat pokazuje, jak zmienia się atrakcyjność transportu publicznego i motoryzacji indywidualnej w zależności od oferowanych możliwości. Wzrost cen biletów transportu publicznego prowadzi często do spadku liczby pasażerów, czyniąc komunikację publiczną mniej efektywną, wpływając dodatkowo na rozwój motoryzacji. Rozwój motoryzacji to wzrost poziomu kongestii, spadek punktualności transportu publicznego... i kolejne argumenty przemawiające za wzrostem atrakcyjności samochodu. Oczywiście tendencje te można odwrócić - zmniejszając ceny biletów, przyspieszając komunikację publiczną, zmniejsza się atrakcyjność motoryzacji indywidualnej.

Co ważne, istnieje potencjał dla utrzymywania pewnego poziomu motoryzacji w przestrzeni miejskiej. Efektywna motoryzacja w kontekście miejskim, biorąc pod 
uwagę dostępną technologię i innowacyjne koncepcje mobilności, jest zdecydowanie możliwa. A kluczem do zrozumienia tego tematu jest obecna nieefektywność wykorzystania samochodów w miejskiej przestrzeni - brakuje paradygmatu, który pozwoliłby tę nieefektywność wyeliminować (Janasz, 2018).

Możliwe jest wpłynięcie na kształt „błędnego koła komunikacji miejskiej” z wykorzystaniem innowacji. Wzrost atrakcyjności motoryzacji indywidualnej jest nieodłącznie związany z postrzeganiem samochodu jako atrakcyjnego, elastycznego, dającego niezależność środka transportu. Wizerunek ten jest podsycany aktywnościami marketingowymi producentów pojazdów. Obecnie trend motoryzacyjny związany z wdrażaniem pojazdów hybrydowych i elektrycznych sprawia, że samochód jest przedstawiany już nie tylko jako elastyczny, ale także ekologiczny środek transportu. W efekcie promowanie i rozwijanie transportu publicznego staje się dla miast istotne jak nigdy wcześniej.

Poszczególne elementy wspomnianego „błędnego koła” mogą być zestawione z opisywanymi w dalszej części opracowania innowacjami. Wzrost wielkości zatorów ulicznych i zjawisko kongestii może być częściowo niwelowane rozwiązaniami informatycznymi. Systemy klasy ITS pozwalają na elastyczne i bardziej efektywne zarządzanie ruchem pojazdów - zarówno samochodów, jak i autobusów czy tramwajów. Rozwiązaniem, które może częściowo niwelować negatywny odbiór zmniejszonej punktualności pojazdów, są systemy dynamicznej informacji pasażerskiej. Oczywiście byłoby idealnie, gdyby pojazdy komunikacji miejskiej się nie spóźniały, skoro jednak już spóźnienie występuje, to informacja o jego wielkości może być dzięki odpowiednim narzędziom udostępniana pasażerom. Systemy ITS, poprzez nadawanie priorytetu pojazdom komunikacji publicznej, pozwalają na niwelowanie opóźnień i odwrócenie negatywnych trendów związanych ze spadkiem prędkości i punktualności. Mogą wręcz zadziałać w sposób przeciwny - skracając czas przejazdu i podnosząc średnią prędkość eksploatacyjną.

Wzrost atrakcyjności samochodów osobowych to efekt wprowadzania pojazdów nowych, o wyższym standardzie komfortu czy też nowocześniejszych technologicznie. Trend ten może być $\mathrm{z}$ powodzeniem realizowany także $\mathrm{w}$ transporcie publicznym, gdzie alternatywne źródła napędu (w tym pojazdy hybrydowe czy elektryczne) również stanowią ważny argument. A odnowa taboru komunikacji publicznej może stanowić doskonałe źródło podnoszenia jego atrakcyjności - zarówno wizualnej, jak i związanej z komfortem podróży.

Wreszcie w „błędnym kole” pojawia się kwestia cen i opłat. Nowoczesne samochody są coraz droższe, tym ważniejsze staje się zatem, aby zachować odpowiednią proporcję $\mathrm{w}$ zakresie cen biletów, które nawet jeżeli będą się zwiększać, to pozostaną $\mathrm{w}$ atrakcyjnej wysokości $\mathrm{w}$ zestawieniu $\mathrm{z}$ kosztami podróży samochodem osobowym.

Nowoczesny transport publiczny pozwala otworzyć komunikację publiczną na nowe obszary - pojazdy autonomiczne dojadą w przyszłości tam, gdzie dotychczas 
było to nieopłacalne. A w połączeniu z integracją środków transportu, dynamicznym zarządzaniem ruchem i informacją transport publiczny może się stać jeszcze bardziej konkurencyjny w nowoczesnych ośrodkach miejskich. Nie tylko po to, by zatrzymywać negatywne trendy, ale także by wyznaczać dla nich trendy przeciwne.

\subsection{Organizacja transportu publicznego: rola i zadania organizatora oraz operatorów}

Jeszcze kilkanaście lat temu regulacje prawne związane z transportem publicznym były bardzo skąpe, a transport zbiorowy wykorzystywał wówczas między innymi zapisy ustawy o transporcie drogowym (z dnia 6 września 2001 roku z późniejszymi zmianami). Wiele nowych elementów wprowadziła tutaj dopiero Ustawa o publicznym transporcie zbiorowym.

Ustawa o publicznym transporcie zbiorowym z dnia 16 grudnia 2010 roku z późniejszymi zmianami (Ustawa, 2020, s. 1), określa między innymi „zasady organizacji i funkcjonowania regularnego przewozu osób w publicznym transporcie zbiorowym realizowanego na terytorium Rzeczypospolitej Polskiej oraz w strefie transgranicznej, $w$ transporcie drogowym, kolejowym, innym szynowym, linowym, linowo-terenowym, morskim oraz w żegludze śródlądowej”. To podstawowy dokument wyznaczający ramy funkcjonowania transportu publicznego - zarówno w obszarze organizacji, jak i finansowania. Celem ustawy jest między innymi określenie zasad funkcjonowania krajowych przewozów o charakterze regularnym, zatem bez skupiania się na specyficznych aspektach przewozów międzynarodowych czy turystycznych. Sama ustawa funkcjonuje w korelacji z przepisami o charakterze międzynarodowym, między innymi rozporządzeniami Parlamentu Europejskiego i Rady ${ }^{\star}$, ustawa określa na przykład znaczenie podstawowych pojęć z obszaru transportu publicznego. Mając na uwadze tematykę niniejszego opracowania, warto tu przytoczyć kilka z nich.

Publiczny transport zbiorowy to zgodnie z zapisami ustawy (2020, s. 5): „powszechnie dostępny regularny przewóz osób wykonywany w określonych odstępach czasu i po określonej linii komunikacyjnej, liniach komunikacyjnych lub sieci komunikacyjnej". Komunikacja miejska, to natomiast w świetle ustawy (2020, s. 3) „gminne przewozy pasażerskie wykonywane w granicach administracyjnych miasta” czy też miasta i gminy, miast albo miast i gmin sąsiadujących, ,jeżeli zostało zawarte porozumienie lub został utworzony związek międzygminny w celu wspólnej realizacji publicznego transportu zbiorowego, a także metropolitalne przewozy

* Szczegółową listę dokumentów zawarto w art. 3 ustawy. 
pasażerskie". Pojęcie komunikacji miejskiej stanowi zatem de facto zawężenie dla definicji publicznego transportu zbiorowego. Należy zwrócić uwagę na tę drobną różnicę - pojęcia komunikacji miejskiej i publicznego transportu zbiorowego bywają bowiem (zwłaszcza w odniesieniu do transportu w miastach i aglomeracjach) często używane zamiennie, co nie zawsze i nie w każdym kontekście jest merytorycznie poprawne.

Ustawa wprowadza podział na operatora i organizatora transportu publicznego. Operator publicznego transportu zbiorowego to „samorządowy zakład budżetowy oraz przedsiębiorca uprawniony do prowadzenia działalności gospodarczej w zakresie przewozu osób, który zawarł z organizatorem publicznego transportu zbiorowego umowę o świadczenie usług $\mathrm{w}$ zakresie publicznego transportu zbiorowego, na linii komunikacyjnej określonej w umowie”, z kolei organizator to „właściwa jednostka samorządu terytorialnego albo minister właściwy do spraw transportu, zapewniający funkcjonowanie publicznego transportu zbiorowego na danym obszarze; organizator publicznego transportu zbiorowego jest »właściwym organem «, o którym mowa w przepisach rozporządzenia (WE) nr 1370/2007" (Ustawa, 2020, s. 4).

Wprowadzenie definicji operatora i organizatora publicznego transportu zbiorowego będzie niezwykle istotne dla dalszych rozważań dotyczących innowacji w szczególności odpowiedzialności za ich wdrożenie czy sposobu finansowania.

Organizatorem publicznego transportu zbiorowego, zgodnie ze wskazywaną ustawą, może być gmina (na terenie własnym lub na terenie innej gminy - na podstawie porozumienia zawartego pomiędzy gminami), związek międzygminny, powiat, związek powiatów, związek powiatowo-gminny, związek metropolitalny, województwo bądź minister właściwy do spraw transportu (Ustawa 2020). Zakres przywoływanych jednostek (samorządowych i nie tylko) jest tu szeroki, gdyż ustawa swoim zasięgiem obejmuje szerokie spektrum przewozów pasażerskich. Zakres oddziaływania jest tu wtórny i oznacza głównie jurysdykcję pod względem terytorialnym, niezależnie od niego zadania organizatora pozostają bowiem takie same. Obejmują one zgodnie z art. 8 ustawy o publicznym transporcie zbiorowym: planowanie rozwoju transportu, organizowanie publicznego transportu zbiorowego i zarządzanie publicznym transportem zbiorowym (Ustawa, 2020).

Szczegółowy zakres zadań organizatora wynika bezpośrednio z zapisów usta$w^{*}$ i obejmuje między innymi organizowanie publicznego transportu zbiorowego. Organizowanie jest tu rozumiane jako badanie i analiza potrzeb przewozowych, podejmowanie działań zmierzających do realizacji istniejącego planu transportowego, zapewnianie odpowiednich warunków funkcjonowania publicznego transportu zbiorowego, określanie sposobu oznakowania środków transportu, określanie przystanków komunikacyjnych i dworców, ustalanie stawek opłat za korzystanie z nich,

* Zadania te zostały przytoczone w możliwie skróconej wersji - celem zwrócenia uwagi na zakres odpowiedzialność organizatora, ale bez zagłębiania się w szczegóły dotyczące zakresu tej odpowiedzialności. 
przygotowanie postępowań prowadzących do zawierania umów o świadczenie usług czy zawieranie tych umów, ustalanie opłat za przewóz osób czy sposobu dystrybucji biletów oraz wykonywanie zadań wskazanych w innych przepisach.

Przy tak szerokim zakresie odpowiedzialności organizator transportu pozostaje często podmiotem niedocenianym, choć wykonuje bardzo szeroki zakres prac planistycznych, organizacyjnych czy nadzorczo-kontrolnych. Tym samym w obszarze działań organizatora znajdzie się wiele możliwości wdrażania innowacji, o czym będzie mowa w dalszych dwóch rozdziałach książki.

Operator jest podmiotem wyłonionym przez organizatora do świadczenia usług transportowych. Istnieje wiele narzędzi wyboru operatora (wybór w trybie ustawy Prawo zamówień publicznych, $w$ trybie koncesyjnym, poprzez powierzenie podmiotowi wewnętrznemu i inne). Każde z tych narzędzi prowadzi jednak do sytuacji, w której operator świadczy usługi w zakresie i zgodnie ze standardami określonymi przez organizatora, a także powoduje powstaje sytuacji, w której następuje wzajemna kooperacja obu stron w związku $\mathrm{z}$ realizowaną umową. To $\mathrm{z}$ kolei powoduje możliwość pojawienia się innowacji na wielu polach.

Oddzielenie funkcji operatora od organizatora jest od wielu lat przedmiotem dyskusji, między innymi w odniesieniu do usług transportu publicznego. Już w latach 90. Wyszomirski (1997, s. 118) wskazywał, że „zmiana modelu gospodarki w naszym kraju, która dokonała się w 1989 roku, oraz przejęcie komunikacji miejskiej przez gminy jako zadania własnego, uzewnętrzniły wady stosowanego modelu organizacji i zarządzania komunikacją miejską i spowodowały powstanie sytuacji, w której wystąpiły zagrożenia dla stabilności finansowania jej działalności”. I to jeszcze na długo przed pojawieniem się ustawy o publicznym transporcie zbiorowym (co nastąpiło, jak wcześniej wspomniano, w 2010 roku).

Wyszomirski już wówczas wskazywał możliwy i stopniowo realizowany kierunek zmian. „Poszukując nowych rozwiązań w organizacji i zarządzaniu komunikacją miejską, w niektórych miastach zdecydowano się na przyjęcie i dostosowanie do określonych warunków modelu zakładającego oddzielenie działalności organizatorskiej od przewozowej. Model ten przewiduje publiczną regulację przewozów i wprowadzenie konkurencji w świadczeniu usług przewozowych. Rozdzielając funkcję organizatora komunikacji miejskiej od funkcji wykonawczych, można osiągnąć korzyści, takie jak w wyniku podziału pracy w transporcie ładunków" (Wyszomirski, 1997, s. 119). Wspominane wprowadzanie konkurencji na rynkach transportowych odbywa się $\mathrm{w}$ ostatnich dwudziestu latach $\mathrm{z}$ różnym skutkiem (z uwagi na wiele różnych czynników i uwarunkowań, zarówno krajowych, regionalnych, jak i lokalnych), powszechność modelu opartego na organizatorze i podległych mu operatorach jest jednak faktem.

Należy zauważyć, że zapisy ustawy o publicznym transporcie zbiorowym pozostają w zgodzie i w korelacji z przepisami unijnymi. Mowa tu chociażby o rozporządzeniu Parlamentu Europejskiego i Rady nr 1370 z dnia 23 października 
2007 r. dotyczącym usług publicznych w zakresie kolejowego i drogowego transportu pasażerskiego. Mowa jest tam między innymi o konkurencyjności przedsiębiorstw na rynku, która jest jednym $\mathrm{z}$ najważniejszych narzędzi wspierających poprawę efektywności (Parlament Europejski i Rada, 2007).

Co ważne, innowacyjność może być także wspierana przez samorząd. W naukach ekonomicznych od wielu lat toczy się dyskusja o sposobach ingerencji władz publicznych w rynek i działalność gospodarczą.

Wydatkowanie środków publicznych może owocować efektywnym wzrostem, a wspieranie innowacyjności może się odbywać w szczególności w ramach polityki przemysłowej, ochrony środowiska, edukacji i kultury (Feczko, 2016).

\subsection{Przedsiębiorstwa transportu publicznego - charakterystyka działalności}

W teorii ekonomii znajdziemy kilka podstawowych modeli rynku. Większość z nich występuje także w sektorze transportu publicznego. W niniejszym podrozdziale przedstawiono podstawowe informacje na temat tych modeli, podjęto także rozważania na temat ich wpływu na skłonność przedsiębiorstw do podejmowania innowacji.

Przedstawiono także wybrane przykłady przedsiębiorstw $\mathrm{z}$ odniesieniem do konkretnych rodzajów rynku. Zgromadzenie pełnych danych na temat liczby podmiotów świadczących usługi transportu publicznego byłoby niezwykle trudne, chociażby ze względu na ciągłą dynamikę rynku. Powstają nowe przedsiębiorstwa, inne ulegają likwidacji. Jedna forma prawna (spółka) nie wyklucza świadczenia usług na przykład w kilku miastach jednocześnie, co mogłoby zafałszować liczbę faktycznie działających podmiotów. Analizując liczbę i zasięg działania przedsiębiorstw transportu publicznego, skupiono się zatem na trendach i zależnościach, a nie zawsze na pełnym pokryciu liczbowym opisywanego rynku.

W jaki sposób definiować transport publiczny? Jest wiele definicji, pochodzących zarówno z odpowiednich aktów prawnych, jak i publikacji o charakterze naukowym. Na potrzeby tej monografii skupiono się na transporcie publicznym w miastach i aglomeracjach.

Grochowiak, Dutkiewicz i Chrobot (2007, s. 7) proponują podział sieci komunikacji publicznej o charakterze regionalnym na trzy podstawowe grupy:

- duże - w aglomeracjach miejskich - dla regularnego ruchu na stałych liniach komunikacyjnych, niezależnie od pory dnia i dnia tygodnia - w tym komunikację podmiejską; 
- średnie - w miastach do 50 tys. mieszkańców - zarówno te kursujące tylko w dni robocze, jak i w dni świąteczne z ograniczonym zakresem;

- małe - na jednej lub dwóch trasach, zwykle z niewielką częstotliwością.

W Polsce funkcjonuje 14 sieci tramwajowych, w tym 9 normalnotorowych i 5 wąskotorowych. Historia tramwajów na terenie obecnej Polski sięga 1866 roku i uruchomienia pierwszej linii tramwaju konnego w Warszawie. Łącznie do 1903 roku uruchomiono w Polsce 12 sieci tramwajowych. Pierwszy tramwaj elektryczny we Wrocławiu w 1893 roku zapoczątkował trwający do dziś rozwój tramwajów elektrycznych (Lubka i Stiasny, 2004).

\section{Modele rynku}

Wyróżnienie modeli funkcjonowania rynku będzie miało swoje odniesienie do obszarzu innowacyjności. Tam gdzie pojawia się „niewidzialna ręka rynku”, tam w naturalny sposób skłonność przedsiębiorstw do innowacji będzie wyższa. „Każdy musi, częściowo przynajmniej, działać ekonomicznie i każdy musi albo być "podmiotem gospodarującym «, albo też zależeć od jakiegoś podmiotu gospodarującego" (Schumpeter, 1960, s. 2). Dodatkowo w dużych przedsiębiorstwach pojawia się naturalna siła do tworzenia technicznej specjalizacji (Cantwell i Fai, 1999).

„Konkurencja między podmiotami gospodarczymi jest cechą gospodarki rynkowej” (Rekowski, 2002, s. 203). Wyróżnienie w tej konkurencji dwóch podstawowych sposobów walki o klienta, czyli konkurencji cenowej i niecenowej (pozacenowej), pozwala zwrócić uwagę na rolę, jaką w transporcie publicznym mogą odebrać innowacje. Jeżeli bowiem uznamy, że o konkurencyjności danego produktu decyduje nie tylko jego cena, ale także inne elementy, jest tu miejsce na konkurowanie także na poziomie innowacyjności.

W przypadku transportu publicznego można mówić o różnych formach konkurencji - zarówno pomiędzy operatorami, jak i pomiędzy poszczególnymi środkami transportu. A także pomiędzy transportem publicznym a jego alternatywami. W praktyce na innowacyjność będzie wpływać konkurencja pomiędzy operatorami, a także konkurencja pomiędzy transportem publicznym a chociażby motoryzacją indywidualną. W tym pierwszym przypadku innowacyjność przedsiębiorstw będzie prowadzić do wzmocnienia ich pozycji rynkowej w ramach konkurowania z innymi operatorami, a w drugim - do zwiększenia atrakcyjności transportu publicznego względem innych form transportu. W obu przypadkach można mówić o rywalizacji niecenowej. Na rynku transportu publicznego można wyróżnić kilka przykładowych modeli konkurencji. Rynek przedsiębiorstw transportu publicznego jest rynkiem mocno zróżnicowanym, znajdą się na nim między innymi monopole naturalne. Tak jest chociażby w przypadku transportu kolejowego czy miast i aglomeracji, w których obsługę komunikacyjną świadczy jeden podmiot. 
Z punktu widzenia mikroekonomii o pełnym monopolu możemy mówić wówczas, gdy „w danej gałęzi przemysłu istnieje tylko jedno przedsiębiorstwo wytwarzające produkt nieposiadający substytutów" (Rekowski, 2002, s. 229). Czy zatem na rynku transportu publicznego możemy mówić o takim pełnym monopolu? Teoretycznie usługa transportowa często posiada substytuty (pod postacią chociażby innych środków transportu). $Z$ drugiej strony jednak nie zawsze są one dostępne, pozostaje też pytanie, czy zawsze możemy je uznać za substytut.

„Dwa dobra są substytutami, jeżeli zmiana ceny (wzrost, spadek) na jeden z produktów, przy niezmienionej cenie drugiego, przesuwa popyt konsumentów w kierunku dobra tańszego" (Rekowski, 2002, s. 43). W przypadku usług transportowych, gdzie za ustalenie ceny odpowiada organizator transportu, nie można mówić o wzroście lub spadku ceny. Można natomiast mówić o zwiększeniu lub zmniejszeniu dostępności czy atrakcyjności danego środka transportu. Zakładając zatem, że relacja pomiędzy popularnością poszczególnych środków transportu występuje (a popularność docelowo przekłada się na poziom płatności po stronie organizatora), można tu mówić o substytucyjności.

Na rynku transportowym coraz rzadziej występują monopole naturalne - to efekt wieloletniego liberalizowania rynków. Na rynku transportowym istnieją także oligopole. Znacznie rzadziej można mówić o konkurencji monopolistycznej. Należy zauważyć, że rynek transportu publicznego jest rynkiem regulowanym, zatem zwykle nie ma na nim pełnej swobody i braku barier wejścia.

Monopole naturalne mogą się formować zwłaszcza tam, gdzie istniejące ograniczenia przestrzenne (chociażby w miastach) czy też infrastrukturalne (na przykład $\mathrm{w}$ transporcie kolejowym czy miejskim transporcie szynowym) utrudniają wprowadzanie konkurencji. Z kolei oligopolem stają się koleje regionalne czy miasta powierzające obsługę przewozów na podstawie przetargów czy umów wieloletnich z operatorami różnych trakcji. Czy można tu mówić o konkurencji doskonałej? Biorąc pod uwagę aktualną konstrukcję rynku opartą na pewnej regulacji, model konkurencji doskonałej jest trudny do osiągnięcia.

\section{Przykładowe profile przedsiębiorstw i sposób organizacji przewozów}

Liczba podmiotów świadczących usługi transportu publicznego wzrasta. Przykładowo w 1955 roku było 39 przedsiębiorstw i zakładów komunikacji miejskiej, a w 1987 roku było ich już 93 (Gługiewicz, 1991, za: Kubieniec i Rataj, 1988). Do największych operatorów publicznego transportu zbiorowego zaliczyć można między innymi przewoźników komunalnych w największych ośrodkach miejskich. Łącznie liczbę przewoźników autobusowych miejskich na polskim rynku można oszacować na co najmniej kilkaset firm.

W niniejszym podrozdziale przedstawiono dwa przykładowe systemy komunikacji publicznej, wskazując ich profil działalności i realizowane zadania. 
Wybrano odmienne przykłady - aby zobrazować różnice pomiędzy przedsiębiorstwami w różnych częściach kraju. Mając na uwadze liczbę przedsiębiorstw transportu publicznego (jak już wcześniej wspomniano - podawaną co najmniej w setkach), przedsiębiorstwa te należy potraktować jako przykładowe, a ich listę jako niewyczerpującą wszystkich możliwych profili przedsiębiorstw działających na tym rynku.

W doborze studiów przypadków najistotniejsze było kryterium złożoności systemów transportu publicznego oraz ich intermodalności (integracji różnych środków transportu). W rozbudowanych systemach transportu publicznego łatwiej zaobserwować wskazywane trendy, a z uwagi na wysokie budżety inwestycyjne znacznie więcej projektów o charakterze innowacyjnym udaje się zrealizować. Dlatego Warszawa i Kraków plasują się w czołówce polskich miast we wszelkich rankingach dotyczących jakości transportu publicznego.

\section{Zarząd Transportu Publicznego w Krakowie i MPK S.A. w Krakowie}

Obecny model zarządzania transportem publicznym w Krakowie funkcjonuje od 1 sierpnia 2006 roku. W szczególności obejmuje on takie elementy, jak:

- obecność wyspecjalizowanej jednostki miejskiej zajmującej się organizacją i zarządzaniem komunikacją miejską na terenie gminy miejskiej Kraków, a od 1 stycznia 2008 roku także dodatkowo w obszarze aglomeracji krakowskiej na podstawie porozumień międzygminnych;

- długoterminowa umowa o świadczenie usług publicznych zawarta z głównym operatorem, czyli Miejskim Przedsiębiorstwem Komunikacyjnym S.A.;

- działania związane ze wsparciem tych usług operatora także usługami świadczonymi przez sektor prywatny (docelowo do 15\% przewozów autobusowych);

- rezerwacja środków na zapłatę umów wykonawcom usług przewozowych oraz innych usług w budżecie miasta Krakowa (wpływy ze sprzedaży biletów i nałożonych usług dodatkowych stanowią dochód budżetu miasta) (Zarząd Transportu Publicznego w Krakowie, 2021).

W praktyce zadania składające się na tworzenie całokształtu transportu publicznego są podzielone pomiędzy kilka jednostek i instytucji. Obok organizatora transportu i operatorów stroną jest tutaj także gmina miejska Kraków, której na mocy zawartych porozumień powierzono wykonywanie określonych zadań - de facto to gmina zapewnia usługi przewozu osób. Po stronie miasta leżą także prawa i obowiązki właścicielskie związane ze wszystkimi elementami infrastruktury transportu zbiorowego - w szczególności w zakresie zarządu nad obiektami i urządzeniami. Zadania te wykonuje w imieniu miasta dedykowana jednostka: Zarząd Infrastruktury Komunalnej i Transportu (ZIKiT), a dotyczy to między innymi pętli 
i dworców autobusowych, torowisk i pętli tramwajowych (wraz z siecią trakcyjną, elementami zasilania, podstacjami trakcyjnymi) czy przystanków (Zarząd Transportu Publicznego w Krakowie, 2021).

Obecnie za organizację transportu miejskiego odpowiedzialny jest Zarząd Transportu Publicznego w Krakowie. Z kolei MPK S.A. w Krakowie świadczy usługę przewozową na podstawie umowy na świadczenie usług komunikacji miejskiej, podpisanej z gminą miejską Kraków (MPK Kraków, 2021c). Do podstawowych zadań MPK S.A. w Krakowie należy przewóz pasażerów, dodatkowym zadaniem operatora jest także dystrybucja biletów. Z kolei po stronie organizatora pozostają takie zadania, jak: decyzje dotyczące lokalizacji nowych przystanków na terenie miasta, zwiększanie częstotliwości kursowania autobusów i tramwajów, zmiany tras komunikacji miejskiej, uruchamianie nowych linii komunikacyjnych czy kontrola biletów. Poza obszarem działania MPK S.A. w Krakowie jest także ustalanie cen biletów - o tym decyduje Rada Miasta Krakowa (MPK Kraków, 2021c).

Miejskie Przedsiębiorstwo Komunikacyjne S.A. w Krakowie jest jednym z większych operatorów komunikacji miejskiej w Polsce. Historia komunikacji miejskiej w Krakowie sięga 1875 roku. W 1882 roku oddano do użytku pierwszą wąskotorową linię tramwajową (tramwaju konnego), w 1913 roku - pierwszą normalnotorową linię tramwajową, w 1927 roku - pierwszą linię autobusową (MPK Kraków, 2021a). Przedsiębiorstwo zatrudnia obecnie 2310 osób, z czego dominującą grupę (1142 osób, czyli 49,4\% załogi) stanowią prowadzący pojazdy. Zestawienie stanowisk pracy przedstawiono $\mathrm{w}$ tabeli 3.1.

Tabela 3.1. Zatrudnienie w MPK S.A. w Krakowie

\begin{tabular}{|l|c|c|c|c|}
\hline \multirow{2}{*}{\multicolumn{1}{|c|}{ Stanowisko pracy }} & \multicolumn{4}{|c|}{ Liczba etatów } \\
\cline { 2 - 5 } & $\mathbf{2 0 1 7}$ & $\mathbf{2 0 1 8}$ & $\mathbf{2 0 1 9}$ & $\mathbf{2 0 2 0}$ \\
\hline Prowadzący pojazdy & 1124 & 1186 & 1145 & 1142 \\
- kierowcy & 667,5 & 705 & 692 & 705 \\
- motorniczowie & 456,5 & 481 & 453 & 437 \\
\hline Pracownicy zaplecza i obsługi & 726 & 732 & 735 & 718 \\
\hline Pracownicy umysłowi & 436 & 443 & 453 & 450 \\
\hline Ogółem zatrudnienie & 2286 & 2361 & 2333 & 2310 \\
\hline
\end{tabular}

Źródło: (MPK Kraków, 2021b).

W ramach pionu organizacyjnego podległego dyrektorowi ds. technicznych istnieje pięć stacji obsługi: dwie stacje obsługi tramwajów (Nowa Huta, Podgórze) i trzy stacje obsługi autobusów (Bieńczyce, Wola Duchacka, Płaszów) (MPK Kraków, 2021b). MPK Kraków eksploatuje flotę 620 autobusów i 377 tramwajów (tabela 3.2). 
Tabela 3.2. Tabor autobusowy MPK S.A. w Krakowie

\begin{tabular}{|l|c|c|c|c|}
\hline \multicolumn{1}{|c|}{ Typ } & $\begin{array}{c}\text { Zajezdnia } \\
\text { TB }\end{array}$ & $\begin{array}{c}\text { Zajezdnia } \\
\text { TP }\end{array}$ & $\begin{array}{c}\text { Zajezdnia } \\
\text { TW }\end{array}$ & Razem \\
\hline Solaris Urbino 12 & 86 & 66 & 35 & 187 \\
\hline Solaris Urbino 18 & 32 & 52 & 70 & 154 \\
\hline Solaris Urbino 12.9 hybrid & 4 & 0 & 5 & 9 \\
\hline Solaris Urbino 18 hybrid & 12 & 0 & 0 & 12 \\
\hline Mercedes 628 G (przeg.) Citaro/Conecto & 0 & 0 & $28+4$ & 32 \\
\hline Mercedes 628 Citaro/Conecto & 30 & 30 & $34+1$ & 95 \\
\hline Autosan Sancity M09LE & 18 & 0 & 18 & 36 \\
\hline Mercedes /Automet - Sprinter, Karsan & 0 & $3+2 \mathrm{~K}$ & 0 & 5 \\
\hline VOLVO 7900 HYBRID & 12 & 0 & 0 & 12 \\
\hline Solaris Urbino 12E & 0 & 0 & 19 & 19 \\
\hline Solaris Urbino 18E & 0 & 0 & 55 & 55 \\
\hline Solaris Urbino 8.9E & 0 & 0 & 4 & 4 \\
\hline RAZEM & 194 & 153 & 273 & 620 \\
\hline
\end{tabular}

Źródło: https://www.mpk.krakow.pl/pl/tabor/autobusy/. Pobrane: 9 lipca 2021.

Należy zwrócić uwagę na fakt, że operator mocno inwestuje w środki transportu o napędzie alternatywnym. We flocie autobusowej można znaleźć między innymi autobusy hybrydowe (Solaris Urbino 12.9 Hybrid, Urbino 18 Hybrid, Volvo 7800 Hybrid) i elektryczne (Solaris Urbino 8.9E, 12E, 18E). Łącznie to 33 autobusy hybrydowe i 78 autobusów elektrycznych, co stanowi prawie $18 \%$ ogółu posiadanej floty autobusowej.

Tabela 3.3. Tabor tramwajowy MPK S.A. w Krakowie

\begin{tabular}{|l|c|c|c|}
\hline \multicolumn{1}{|c|}{ Typ } & Zajezdnia TH & Zajezdnia TT & Razem \\
\hline KONSTAL 105Na & 37 & 25 & 62 \\
\hline ROTAX/SGP E1 & 36 & 12 & 49 \\
\hline ROTAX/SGP C3 & 26 & 12 & 39 \\
\hline MAN/DUEWAG N8 & 12 & 0 & 12 \\
\hline ROTAX EU8N & 40 & 0 & 40 \\
\hline PROTRAM 405N & 1 & 0 & 1 \\
\hline DUEWAG GT8S & 0 & 28 & 28 \\
\hline BOMBARDIER NGT6 & 0 & 50 & 50 \\
\hline BOMBARDIER NGT8 & 0 & 24 & 24 \\
\hline STADLER TANGO & 26 & 12 & 38 \\
\hline PESA 2014N & 22 & 14 & 36 \\
\hline RAZEM & 200 & 177 & 377 \\
\hline
\end{tabular}

Źródło: https://www.mpk.krakow.pl/pl/tabor/tramwaje/. Pobrane: 9 lipca 2021. 
Podobnie jak w przypadku taboru autobusowego, także i w przypadku taboru tramwajowego wyraźnie widać duży udział nowoczesnych tramwajów niskopodłogowych - takich producentów, jak Bombardier, Stadler czy Pesa. Na chwilę obecną tabor tych trzech producentów to łącznie 148 sztuk taboru, czyli 39,3\% stanu inwentarzowego wagonów tramwajowych (tabela 3.3).

MPK Kraków może posłużyć jako przykład silnego gospodarczo, rozbudowanego operatora transportu publicznego. Spółka obsługuje dwie trakcje (autobusową i tramwajową), intensywnie inwestuje w tabor (zarówno autobusy z napędem alternatywnym, jak i tramwaje niskopodłogowe). Przedsiębiorstwo jest innowacyjne, czego dowodem mogą być chociażby plany pozyskania taboru wodorowego (MPK Kraków, 2021d) czy testy tramwaju przemieszczającego się autonomicznie*.

\section{Warszawski Transport Publiczny i najwięksi operatorzy}

Warszawski Transport Publiczny jest organizowany i nadzorowany przez Zarząd Transportu Miejskiego w Warszawie, dla którego przewozy są realizowane przez operatorów - zarówno komunalnych, jak i prywatnych (Zarząd Transportu Miejskiego w Warszawie, 2021a).

Warszawski sposób organizacji transportu publicznego łączy wiele form dostępu do rynku (patrząc z punktu widzenia nauk ekonomicznych). Jest on największym w skali kraju systemem komunikacji miejskiej, tak jak i Warszawa jest zdecydowanie największym w kraju ośrodkiem miejskim (i centrum aglomeracji). Tym samym Warszawa jest dobrym miejscem do analiz i obserwacji - w zakresie zarówno zarządzania transportem publicznym, i jak wdrażanych innowacji.

Patrząc na warszawski system transportu publicznego, warto wyjść od pozycji organizatora. Zarząd Transportu Miejskiego skupia swoją aktywność na trzech polach: przewozu, handlu i inwestycji. W ramach działalności przewozowej ZTM Warszawa realizuje między innymi zadania dotyczące potrzeb przewozowych - planowania, organizacji i koordynacji układu komunikacyjnego oraz rozkładu jazdy, a także bieżącej koordynacji i nadzoru nad funkcjonowaniem transportu zbiorowego - dla Warszawy i współpracujących gmin. Ważnym elementem działania ZTM jest także prowadzenie postępowań prowadzących do zawarcia umów o świadczenie usług w zakresie transportu zbiorowego (a następnie, po zawarciu tych umów, kontrola jakości ich realizacji). ZTM odpowiada także za zarządzanie i rozwój obiektów infrastruktury komunikacyjnej ( $w$ tym węzłów przesiadkowych, pętli autobusowych i tramwajowych, przystanków czy parkingów typu P\&R). W obszarze handlowym ZTM skupia się na opracowaniu polityki taryfowej, sprzedaży biletów oraz ich kontroli, a w obszarze inwestycyjnym - na inicjowaniu przedsięwzięć inwestycyjnych dotyczących zarówno budowy czy modernizacji obiektów i urządzeń, jak i doko-

\footnotetext{
* Opisane szerzej w rozdziale 4.
} 
nywania zakupów inwestycyjnych związanych z transportem zbiorowym (Zarząd Transportu Miejskiego w Warszawie, 2021a).

Zarząd Transportu Miejskiego w Warszawie współpracuje z operatorami komunalnymi i operatorami prywatnymi. Umowy z operatorami prywatnymi są zawierane między innymi w komunikacji autobusowej, w której obok przewoźnika komunalnego (Miejskie Zakłady Autobusowe, około 1439 autobusów) funkcjonują między innymi Arriva Bus Transport Polska (142 autobusy) czy Mobilis (169 autobusów). Na poniższym schemacie przedstawiono strukturę przewozów z podziałem na trakcje, operatorów i ich formę prawną.

\section{(Zarząd Transportu Miejskiego)}

Warszawski Transport Publiczny

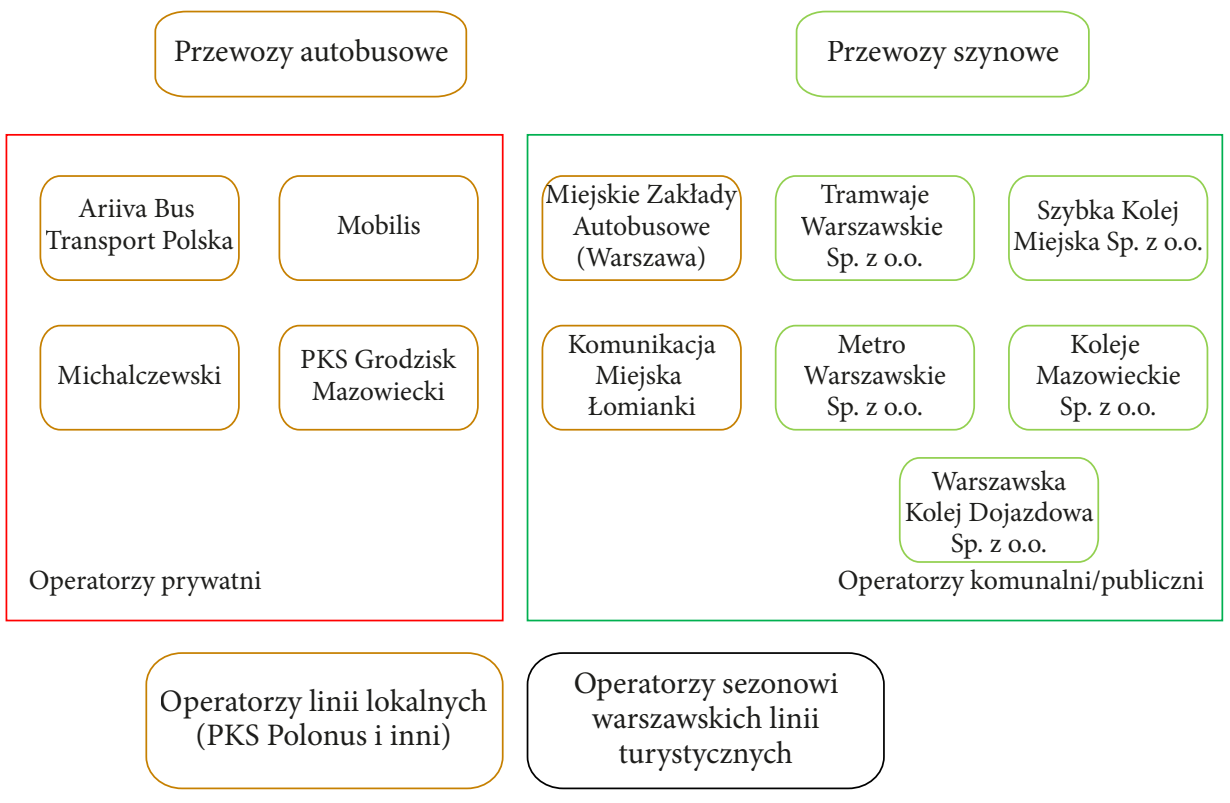

\section{Rysunek 3.2. Operatorzy Warszawskiego Transportu Publicznego}

Źródło: (Zarząd Transportu Miejskiego w Warszawie, 2021c).

W ramach sieci Warszawskiego Transportu Publicznego funkcjonują zarówno operatorzy korzystający z infrastruktury współdzielonej (chociażby operatorzy autobusowi i regionalni operatorzy kolejowi), jak i tacy, którzy działają na dedykowanej infrastrukturze, dostępnej tylko dla nich. Tak jest chociażby w przypadku przewozów tramwajowych (Tramwaje Warszawskie Sp. z o.o.) czy sieci metra (Metro 
Warszawskie Sp. z o.o.), a także (choć tu już w części także poza obszarem miasta) przewozów kolejowych (Warszawska Kolej Dojazdowa Sp. z o.o.). Z punktu widzenia realizowanej pracy przewozowej największy jest udział Miejskich Zakładów Autobusowych (praca przewozowa na poziomie $85,7 \mathrm{mln}$ wozokm, 32\% przewozów), Tramwajów Warszawskich (52,3 mln wozokm, 20\% przewozów) i Metra Warszawskiego (42,1 mln wozokm, 16\% przewozów) (Zarząd Transportu Miejskiego w Warszawie, 2021b).

Warszawski Transport Publiczny (sieć Zarządu Transportu Miejskiego w Warszawie) to największy system aglomeracyjnego transportu publicznego $\mathrm{w}$ kraju (tabela 3.4). Należy zwrócić uwagę na kilka jego charakterystycznych elementów:

Tabela 3.4. Zestawienie operatorów w sieci ZTM Warszawa z uwzględnieniem liczby wozów w ruchu

\begin{tabular}{|l|l|c|l|}
\hline \multicolumn{1}{|c|}{ Operator } & Trakcja & $\begin{array}{c}\text { Liczba wozów } \\
\text { w ruchu }\end{array}$ & \multicolumn{1}{c|}{ Uwagi } \\
\hline Tramwaje Warszawskie & tramwaj & 792 & podano przeliczeniową liczbę wagonów \\
\hline Metro Warszawskie & metro & 324 & podano liczbę wagonów \\
\hline Szybka Kolej Miejska & kolej & 122 & podano liczbę wagonów \\
\hline Miejskie Zakłady Autobusowe & autobus & 1127 & \\
\hline Mobilis & autobus & 147 & \\
\hline Arriva & autobus & 126 & \\
\hline PKS Grodzisk Mazowiecki & autobus & 50 & \\
\hline Michalczewski & autobus & 25 & \\
\hline KM Łomianki & autobus & 24 & \\
\hline Wszyscy operatorzy łącznie & & 2737 & \\
\hline
\end{tabular}

Źródło: (Zarząd Transportu Miejskiego w Warszawie, 2021b).

- tramwaje Warszawskie Sp. z o.o. - przewoźnik tramwajowy posiada monopol w swojej trakcji, który zasadniczo jest monopolem naturalnym, operator odpowiada dodatkowo za zarządzanie (swoją) infrastrukturą;

- metro Warszawskie Sp. z o.o. - jedyny w kraju przewoźnik metra; odpowiada za obsługę kolei podziemnej na dwóch głównych liniach, a dodatkowo za zarządzanie infrastrukturą i systemami związanymi z koleją podziemną;

- Miejskie Zakłady Autobusowe Sp. z o.o. - największy miejski przewoźnik autobusowy w kraju; z 1499 autobusów wyjeżdżających na trasy w ramach WTP 1127 (75,2\%) stanowią autobusy MZA (Informator ZTM, 2021, s. 4);

- największa w skali kraju liczba autobusów uruchamianych przez operatorów prywatnych - choć z uwagi na skalę działania całego systemu transportowego procentowy udział w liczbie uruchamianych autobusów ogółem nie wydaje się duży. 


\section{4. Świadczenie usługi i oczekiwania klientów}

Usługi transportu publicznego są ciekawym tematem do badań i analiz między innymi ze względu na subiektywizm oceny użytkownika. Klient ocenia usługę z perspektywy jednostki, a jednostkowa ocena może bardzo mocno się różnić od oceny systemowej.

W literaturze przedmiotu wiele uwagi poświęca się kryteriom oceny jakości usług przewozowych. Wypracowane są uniwersalne wskaźniki oceny tej jakości, które przedstawiono poniżej. Należy jednak zauważyć, że część tych wskaźników ma charakter subiektywny, wynikający $z$ indywidualnej oceny danych kryteriów przez pasażerów. Warto tu wskazać chociażby temat temperatury w pojazdach jak powszechnie wiadomo, odczuwanie temperatury przez każdego człowieka jest odmienne, a pojazd komunikacji publicznej nigdy nie zapewni takich warunków temperaturowych, które odpowiadałyby każdej jednostce. Subiektywizm oceny sprawia, że tym bardziej konieczne jest wypracowanie uniwersalnych standardów i zasad, tak aby w możliwie obiektywny sposób zapewnić jak najlepsze warunki podróżowania i spełniać oczekiwania możliwie dużej grupy klientów.

Na początek warto się zastanowić, jakie mogą być kryteria obiektywnej oceny jakości komunikacji publicznej jako systemu transportowego cechującego się odpowiednim poziomem sprawności. Mogą nimi być (Rejmoniak, 1985):

- czas jazdy,

- regularność jazdy,

- częstotliwość kursowania,

- punktualność jazdy,

- dogodność połączeń,

- wygoda podróżowania,

- bezpieczeństwo jazdy,

- informacja,

- kultura obsługi.

Każdy z tych punktów stanowi osobny, duży obszar zainteresowania badających transport publiczny. W największym skrócie czas jazdy jest rozumiany jako prędkość przemieszczania się pojazdu i przekłada się bezpośrednio na rzeczywiście pokonywany dystans. Regularność kursowania pojazdów to stały interwał pomiędzy poszczególnymi kursami, pożądany przy planowaniu podróży i ułatwiający zapamiętanie rozkładu jazdy. Częstotliwość kursowania to odstęp między kursami uznawany niekiedy za kryterium oceny sprawności - zwłaszcza gdy wysoka częstotliwość kursowania pozwala na osiągnięcie wysokiej przepustowości, niezbędnej do uzyskania w przestrzeni miejskiej. Punktualność jazdy to wskaźnik jakościowy oceniający wykonanie zadań przewozowych. Dogodność połączeń ma związek z więźbą ruchu, 
czyli układem połączeń i ich wzajemną korelacją w przestrzeni miejskiej. Wygoda podróżowania to ogrzewanie, wentylacja, łatwość wejścia do pojazdu - zwłaszcza te dwa pierwsze punkty to kryteria zdecydowanie subiektywne. Punktem subiektywnej oceny jet też informacja (choć zwykle wyznacza się tu konkretne i ściśle określone standardy). Subiektywny jest też ostatni wskaźnik Rejmoniaka - kultura obsługi, czyli zachowanie pracowników komunikacji zbiorowej.

\section{Kryteria oceny satysfakcji klienta}

Istnieje wiele kryteriów oceny jakości usług przewozowych. Część z nich wspomniano powyżej. Zgodnie z definicją: „Jakość to spełnianie wymagań będących odbiciem potrzeb lub oczekiwań. Oczekiwania i potrzeby wyrażają klienci, nabywcy i użytkownicy wyrobów i usług. Spełniają je producenci i dostawcy" (Hamrol, 2017, s. 11). Idąc tym tropem, należy się zastanowić, na ile dostawca usługi transportu publicznego (operator, organizator) podlega dziś ocenie klienta (pasażera).

Jest wiele elementów składających się na ocenę jakości podróży. Są wśród nich zarówno elementy jednoznaczne, jak i trudne do oceny. Na przykład na ocenę wygody podróży składają się elementy związane z oczekiwaniem na podróż, ważne jeszcze przed jej rozpoczęciem (prostota systemu taryfowego, estetyka czy bezpieczeństwo oczekiwania na przystanku) oraz elementy związane z samą podróżą. Wśród tych ostatnich są między innymi łatwość wsiadania i wysiadania, płynność i cichość jazdy, oświetlenie i klimatyzacja, rozmieszczenie drzwi i siedzeń, rodzaj siedzeń, wystrój wnętrza, kultura obsługi, dostęp do kasowników i miejsca na bagaż, czytelne oznakowanie kierunku jazdy (Wyszomirski, 1997).

Co ważne, należy pamiętać o tym, że kryteria komfortu są bardzo często subiektywne. „Jeden użytkownik oczekiwać będzie przede wszystkim pojazdu niskopodłogowego, inny - klimatyzacji przestrzeni pasażerskiej, jeszcze inny - dodatkowych półek na bagaż" (Jurczak, 2013, s. 19). Subiektywizm potrzeb stanowi jedno $\mathrm{z}$ ważnych wyzwań związanych z modernizacją systemów transportu publicznego. O ile w przypadku rozwiązań technicznych, związanych na przykład z ochroną środowiska, fakt modernizowania floty nie podlega dyskusji, o tyle w przypadku udogodnień wpływających na komfort podróży odpowiednia priorytetyzacja potrzeb jest bardzo często mocno subiektywna. To sprawia, że miasta stoją przed ważnym wyzwaniem nie tylko podnoszenia komfortu podróży transportem publicznym, ale przede wszystkim - identyfikacji potrzeb w tym zakresie.

Wśród pasażerów komunikacji miejskiej niemały odsetek stanowią ci, którzy posiadają własny samochód (lub mają samochód do dyspozycji). „Głównymi przyczynami wykorzystywania samochodu osobowego w podróżach miejskich są: krótszy czas podróży samochodem, lepsze warunki jazdy samochodem, brak konieczności oczekiwania na pojazd, wykorzystywanie samochodu jako narzędzia pracy, brak konieczności dojścia do i z przystanku czy większe bezpieczeństwo 
osobiste" (Wyszomirski, 2010, s. 65). Odpowiednia wygoda i komfort (składające się na całościowy proces podróży) stają się ważnym elementem zachęcającym do korzystania z komunikacji publicznej. „Zwiększenie wykorzystania w podróżach miejskich transportu zbiorowego prawdopodobnie możliwe byłoby wtedy, gdyby ten rodzaj transportu w większym stopniu przystawał do oczekiwań użytkowników. Liczne badania wskazują, że generalnie za najważniejsze postulaty pasażerowie komunikacji miejskiej uznają (w różnej konfiguracji) punktualność, niezawodność, częstotliwość i cenę biletów" (Szołtysek, 2016, s. 64). Jeżeli zatem transport publiczny ma w większym stopniu spełniać oczekiwania użytkowników, musi to dotyczyć także komfortu jazdy.

„Zachowania komunikacyjne (...) to decyzje w zakresie sposobu podróży (pokonywania przestrzeni) oraz sam proces realizacji przemieszczenia. Decyzje o sposobie podróżowania podejmowane są na podstawie poglądów, opinii, przekonań kształtujących wyobrażenie o tym, w jaki sposób można najlepiej dla siebie pokonywać przestrzeń. Jest to niezwykle istotna uwaga w aspekcie prób zmiany zachowań komunikacyjnych w miastach, które wymagają, by dla dobra ogółu (a zatem i w pewnym zakresie również osoby podejmującej decyzję o podróży) zrezygnować z części wygód i zdecydować się na mniej atrakcyjny sposób pokonywania przestrzeni" (Szołtysek, 2011, s. 145). Pasażer jest zatem gotów zrezygnować z części wygód towarzyszących mu w podróży samochodem (w imię wyższego dobra, jakim jest dobro ogółu), wciąż jednak chciałby korzystać z usługi o maksymalnie wysokim poziomie komfortu - usługi, która (podobnie jak chociażby samochody osobowe) stale ewoluuje i dopasowuje się do aktualnych potrzeb.

„Pokonywanie barier rozwojowych jest warunkiem funkcjonowania miast” (Szołtysek, 2005, s. 60-61). Rozwój miasta jest rozumiany jako rozwój społeczny, gospodarczy i przestrzenny integralnego organizmu. Jest on możliwy, gdy działania rozwojowe są harmonizowane, a efektem jest kreowanie nowych oraz poprawa istniejących walorów użytkowych miasta, decydujących o jego atrakcyjności dla użytkowników - zarówno obecnych, jak i przyszłych (Szołtysek, 2005).

O ocenie miasta jako miejsca do życia decyduje wiele różnych czynników. „Jakość życia obejmuje wiele obszarów związanych z codziennym funkcjonowaniem człowieka (...). Wśród dziedzin wpływających na jakość życia jest także aspekt związany z przemieszczaniem się po mieście" (Kiba-Janiak i Witkowski, 2014, s. 24) Jakość tego transportu ma zatem wpływ na postrzeganie jakości życia w mieście. „W przypadku transportu uzyskanie wysokiej jakości produktów, czyli usług przewozowych, uzależnione jest od jakości posiadanych zasobów, wśród których nieoceniony jest zasób wiedzy o procesach informacyjnych i procesach przewozowych. Zasoby i procesy zazębiają się, a jakość każdego z nich wpływa na wartość usługi przewozowej - produktu, który otrzymuje klient" (Gostowska-Dźwig i Mrozik, 2017, s. 160).

Ocena jakości życia w mieście (a zatem i pośrednio zadowolenia $\mathrm{z}$ usług transportowych) jest bardzo często prowadzona z perspektywy środowiskowej. „Analiza, 
najczęściej stosowanych do oceny jakości życia w mieście, programów oceniających (rankingowych) wykazuje, że w bardzo różnym stopniu i zakresie uwzględnia się $\mathrm{w}$ nich obszar funkcjonowania miasta związany $\mathrm{z}$ zaspokajaniem potrzeb transportowych mieszkańców. Większość z nich, jeżeli odnosi się do tego obszaru życia miasta, to najczęściej bazuje na informacjach dotyczących wpływu transportu na środowisko" (Komsta, Droździel i Opielak, 2019, s. 396). Osobną kwestią pozostaje poziom zadowolenia $\mathrm{z}$ usług, a zatem i z realizacji potrzeby po stronie klienta.

\section{Narzędzia pomiaru satysfakcji klienta}

Istnieje wiele narzędzi do pomiaru satysfakcji klienta. Z uwagi na specyfikę poszczególnych sieci komunikacyjnych oraz układ przestrzenny miast możliwości prowadzenia analiz porównawczych są często ograniczone. W literaturze przedmiotu można co prawda znaleźć wiele zestawień chociażby cen biletów czy standardów jakości, w praktyce jednak ciężko mówić o ich pełnej porównywalności. Stąd też ważna jest rola oceny jakościowej. Oczywiście ocena jakościowa może mieć charakter subiektywny, stąd też trudne jest skupienie się na obiektywnych (w miarę możliwości) miernikach jakości komunikacji publicznej. W praktyce zwykło się utożsamiać kryteria oceny satysfakcji użytkowników z uniwersalnymi miernikami jakości, dotyczącymi częstotliwości kursowania czy komfortu podróży.

Maksymalizacja komfortu podróżowania komunikacją publiczną ma stanowić źródło kompromisu - poprzez podnoszenie standardu podróżowania tak wysoko, jak tylko jest to (technicznie i ekonomicznie) możliwe. Należy pamiętać, że poziom wyposażenia pojazdów komunikacji miejskiej to często wypadkowa potrzeb mieszkańców i aspiracji władz miasta oraz możliwości samorządowego budżetu. Wiele elementów wyposażenia wymaga dopłaty, a konfiguracja pojazdu to zwykle efekt konkretnych wymagań klienta i jego indywidualnych preferencji. Powszechną praktyką jest dokonywanie zakupów za pośrednictwem zamówień publicznych, w których określa się funkcjonalność, a niezwykle trudno jest opisać i odpowiednio zdefiniować elementy wizualne czy szczegółowe funkcjonalności. $Z$ drugiej strony daje to możliwość zakupu pojazdów różnych producentów, o podobnym wyposażeniu funkcjonalnym.

W kolejnym rozdziale wskazano kilka przykładów, jak zmieniają się potrzeby klientów, a także jak ewolucja ta wpływa na usługi świadczone w ramach transportu publicznego. Warto tu ponownie wspomnieć, że wskutek szybkiego rozwoju i postępu technicznego rozwiązania traktowane jeszcze dekadę czy dwie temu jako innowacyjne dziś za takie uznawane nie są. Stąd też krótki przegląd rozwiązań $\mathrm{z}$ ostatnich kilkunastu lat pozwala zwrócić uwagę na to, jak zmieniały, zmieniają i zmieniać się będą z jednej strony potrzeby, a z drugiej postrzeganie innowacji.

Innowacyjność transportu publicznego może się przełożyć na satysfakcję jego użytkowników. Zasadniczo inwestycja w pojazdy nisko- i zeroemisyjne oznacza 
zmniejszenie poziomu emisji zanieczyszczeń w przestrzeni miejskiej. Z punktu widzenia użytkownika transportu daje ona poczucie zmniejszania oddziaływania na środowisko naturalne i korzystania z proekologicznej formy transportu. Użytkownik może mieć satysfakcję, że uczestniczy w procesie zmniejszania negatywnego wpływu motoryzacji indywidualnej na miejską przestrzeń poprzez wybór innego środka transportu. Pozytywnie na jakość usług i na satysfakcję użytkowników wpływają zatem także chociażby rozwiązania informatyczne. Podnoszą one generalnie jakość usługi: zwiększają średnią prędkość przejazdu czy poprawiają punktualność, pozytywnie wpływając na odbiór komunikacji publicznej przez użytkowników.

\section{Ewolucja potrzeb klienta na przykładzie rozwoju komunikacji autobusowej}

W tym rozdziale wskazano - na przykładzie komunikacji autobusowej w polskich miastach - jak nowe rozwiązania techniczne o innowacyjnym (ale nie tylko) charakterze wpływają na kształt komunikacji publicznej. Jako punkt odniesienia na potrzeby niniejszego opracowania autor przyjmuje zmiany, jakie odnoszą się do komunikacji autobusowej miejskiej i aglomeracyjnej w ostatnich dwudziestu pięciu latach. Taki okres jest wystarczająco długi, aby zaobserwować wyraźne tendencje w zmianach taboru autobusowego. Trwałość takiego taboru według różnych szacunków wynosi od 7-10 do 12-15 lat. Na przykład w miastach amerykańskich przyjmuje się, że trwałość autobusu to około 12 lat (MacKechnie, 2019). W praktyce w polskich aglomeracjach miejskich wymiana taboru wynika przede wszystkim z możliwości budżetu. Zdarza się zatem bardzo często, że spodziewany okres eksploatacji (około dwunastoletni) bywa wydłużany. Niezależnie od tego polskie miasta mają już co najmniej kilkunastoletnie doświadczenie w eksploatacji autobusów niskopodłogowych, a wraz z eksploatacją tych pojazdów można wyciągnąć pierwsze wnioski na temat ich ewolucji funkcjonalnej. Niezależnie od samej trwałości ewolucja komunikacji autobusowej dotyczy także energochłonności pojazdów czy emitowanego poziomu zanieczyszczeń. Zwłaszcza w tym ostatnim obszarze dokonał się w ostatnich latach olbrzymi postęp.

Ewolucja autobusów miejskich oznacza wprowadzenie do eksploatacji wielu różnych rozwiązań technicznych wpływających zarówno na parametry jezdne pojazdu, jak i komfort podróżowania. W ostatnich kilkunastu latach, wraz z upowszechnieniem się autobusów niskopodłogowych, standardem w autobusach miejskich stały się automatyczne skrzynie biegów. Z perspektywy pasażera oznacza to jazdę bardziej płynną, zatem komfortową i bezpieczniejszą. Kolejne generacje autobusów otrzymują coraz bardziej rozbudowane systemy informacji pasażerskiej. Początkowo za pewien standard uznawano przede wszystkim przednią (czołową) i tylną tablicę informacyjną pod postacią tzw. wyświetlacza klapkowego, później diodowego. Uzupełnieniem tych tablic były tablice boczne. $\mathrm{Z}$ czasem coraz częściej zaczęto montować także tablice wewnętrzne, zarówno przedstawiające trasą, którą pokonuje 
pojazd, jak i dodatkowe informacje - od przesiadek, poprzez aktualne komunikaty ruchowe, na reklamach i wiadomościach skończywszy. Systemy informacji pasażerskiej coraz częściej mają także dodatkowe funkcje uwzględniające osoby niewidome lub niedowidzące, jak chociażby możliwość zapowiedzi głosowej wewnątrz pojazdu lub na zewnątrz. Komunikaty takie zwykle są wywoływane w sposób automatyczny, prowadzący pojazd może mieć też możliwość ich wywołania manualnie (na przykład wtedy, gdy widzi osobę niewidzącą wsiadającą do pojazdu).

Autobus niskopodłogowy zapewnił znacznie wyższy komfort wsiadania i wysiadania z pojazdu. W określonych sytuacjach, gdy brakuje platformy przystanku na odpowiedniej wysokości, uzupełnieniem jest w nim rampa dla wózka, rozkładana w sposób manualny lub elektryczny. Odpowiednie wyposażenie stanowiska dla wózka, oparcie czy pasy bezpieczeństwa sprawiają, że podróż ma być nie tylko komfortowa, ale i bezpieczna. Innowacji wpływających na komfort może być coraz więcej. Są to specjalne uchwyty dla rowerów, ładowarki do urządzeń mobilnych. Wśród nietypowych elementów funkcjonalnych może się znaleźć nawet fotelik zapewniający maksymalny komfort i bezpieczeństwo najmłodszym pasażerom (Infobus, 2019c) (rysunki 3.3 i 3.4).

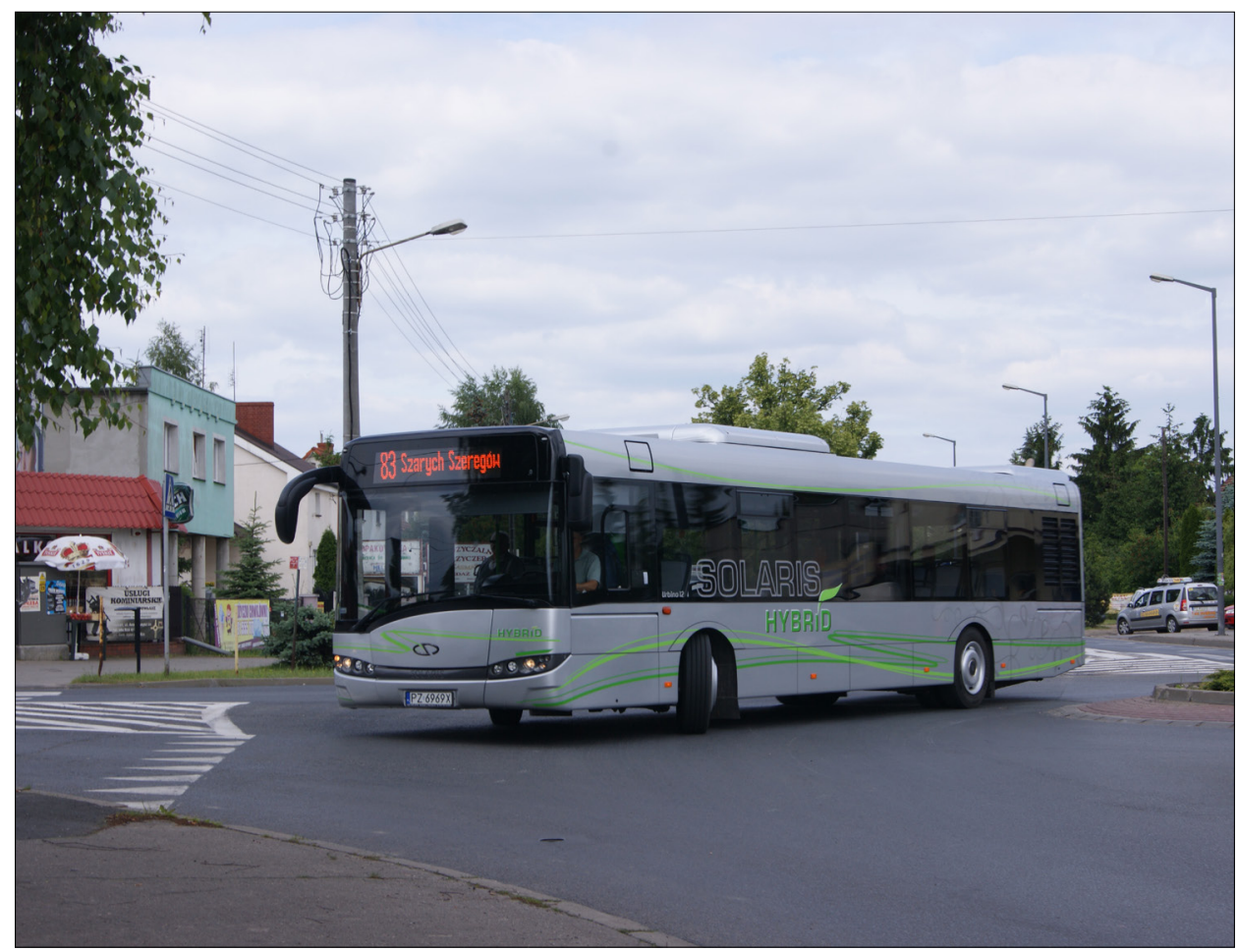

Rysunek 3.3. Autobus Solaris Urbino 12 Hybrid testowany przez Miejskie Przedsiębiorstwo Komunikacyjne w Poznaniu 


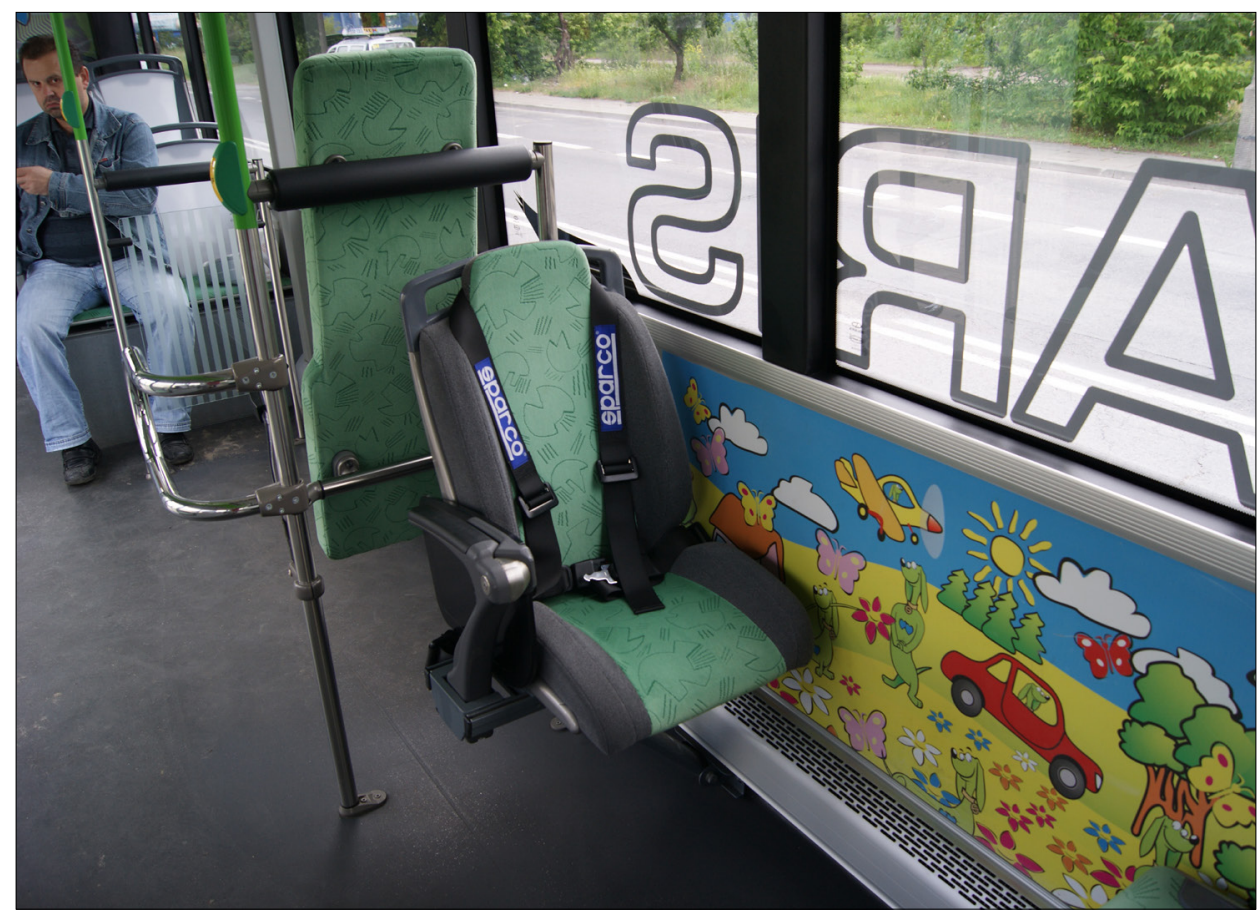

Rysunek 3.4. Autobus Solaris Urbino 12 Hybrid wyposażony w fotelik dziecięcy

Równolegle autobusy miejskie ewoluują pod względem technicznym. To efekt konsekwentnie zaostrzanych norm emisji spalin. Wraz z rozwojem konstrukcji napędzanych tradycyjnymi silnikami diesla pojawiło się kilka pomysłów na napędy alternatywne - od autobusów hybrydowych po elektryczne, ale także napędzanych silnikami spalającymi inne paliwa: gaz ziemny w postaci gazowej lub skroplonej, biopaliwa czy wodór. Ewolucji jednostek napędowych towarzyszy często rozwój pojazdów także od strony technicznej - chociażby poprzez wyposażanie w nowe układy elektroniki, systemy gaszenia silnika i inne urządzenia.

Należy zwrócić uwagę na fakt, że polskie miasta inwestowały w ostatnich latach duże środki finansowe w wymianę taboru autobusowego. W ramach programów zrealizowanych w latach 2007-2015 zakupiono łącznie 1,5 tys. nowych autobusów (i 570 nowych tramwajów). Ankietowani przez Izbę Gospodarczą Komunikacji Miejskiej przewoźnicy wyłożyli na wymianę taboru autobusowego stosunkowo dużo własnych środków. W wybranych miastach wymieniono ponad $70 \%$ taboru autobusowego (na przykład Ełk, Inowrocław, Jaworzno, Słupsk, Szczecin, Puławy), a wśród zakupionych autobusów 26\% stanowiły autobusy używane (Wolański i Pieróg, 2017). Należy przy tym zauważyć, że dotychczasowe inwestycje mają charakter de facto utrzymaniowy - odnowa taboru w całości taboru utrzymuje się bowiem w przedziale 6-8\% rocznie (Wolański i Pieróg, 2017). 
Od 2020 roku zmieniły się potrzeby klientów w zakresie bezpieczeństwa w komunikacji publicznej. Dotychczas transport zbiorowy uchodził za bezpieczny pod względem sanitarnym. Teraz operatorzy i organizatorzy stoją przed nowym wyzwaniem - koniecznością przekonania klientów, że wybór transportu publicznego to rozwiązanie nie tylko atrakcyjne, ale i bezpieczne. Stąd inwestycje w nowe rozwiązania techniczne podnoszące poczucie bezpieczeństwa i nowe reżimy sanitarne. Powszechne w pojazdach transportu publicznego stały się chociażby urządzenia do dezynfekcji rąk (mające postać ręcznych czy automatycznych dozowników odpowiednich środków chemicznych). Bardziej złożonym tematem jest kwestia filtrowania powietrza w pojazdach - tego typu urządzenia są już obecne na rynku, jednak ich montaż w pojazdach $z$ uwagi na koszty i rozmiary urządzeń jest sprawą bardziej złożoną.

\subsection{Kryteria oceny efektywności działania}

Efektywność systemu najłatwiej ocenić samorządowi czy innej instytucji „nadzorczej”. Niestety, poruszając się w realiach budżetowych, ważnym elementem decydującym o ocenie efektywności systemu transportowego pozostaje poziom generowanych przez niego kosztów. A koszty dotyczące infrastruktury (zwłaszcza gdy jest ona w sporej części finansowana na przykład ze środków unijnych) czy koszty zewnętrzne nie są elementami dominującymi.

Niezwykle ciekawym obszarem pozostaje ocena efektywności wdrożenia. Zasadniczo (nie tylko w obszarze transportu publicznego) jednym $z$ istotnych elementów wdrażania innowacji jest ich rachunek ekonomiczny. W przypadku inwestycji w transport publiczny ocena efektywności ekonomicznej jest niezwykle trudna. $\mathrm{Z}$ jednej strony bowiem innowacje mogą się przekładać na korzyści o charakterze jakościowym - związane ze wzrostem jakości usług oferowanych w transporcie publicznym, a z drugiej - na bezpośrednie korzyści finansowe w krótkim okresie.

Analiza wydajności pozwala na ocenę, jak istotne jest przy realizacji projektu nie odpowiednie dzielenie ról, ale konkretne działanie. To pozwala na przykład zupełnie zmienić podejście do planowania transportu publicznego (Lissandrello., Hrelja., Tennøy i Richardson, 2017).

„Poprawa atrakcyjności logistycznej regionów, jak i wdrożenie zasad logistyki do praktyki zarządzania jednostkami terytorialnymi związane są z inwestycjami, często o charakterze infrastrukturalnym. Inwestycje takie pochłaniają zwykle znaczne środki finansowe, nie przynosząc bezpośrednich przychodów $\mathrm{z}$ tytułu odpłatnego udostępnienia infrastruktury. Również projekty logistyki miasta/regionu, związane $\mathrm{z}$ wprowadzeniem instrumentów na przykład redukujących kongestię, w postaci 
wprowadzenia odpłatności za wjazd do centrum miasta, nie są w stanie pokryć poniesionych nakładów inwestycyjnych ani kosztów bieżącej eksploatacji. Ponadto szereg inwestycji infrastrukturalnych stanowi poszerzenie oferty dóbr wolnych, które są udostępniane społeczeństwu nieodpłatnie” (Kauf i Tłuczak, 2014).

Zwykle mówi się o innowacyjności przedsiębiorstw - w tym przypadku na przykład wybranych operatorów. To jednak dosyć istotne uproszczenie. W praktyce bowiem wszelkie innowacje podnoszące koszty funkcjonowania przedsiębiorstwa (operatora) czy organizacji (organizatora) są zwykle finansowane z pieniędzy publicznych. W naturalny bowiem sposób nowe rozwiązania techniczne i dodatkowe nakłady ponoszone na realizację przewozów przekładają się na koszt wykonywania pracy przewozowej. Czyli to podmiot finansujący przewozy (zwykle lokalny samorząd) musi być gotów na innowacyjność - zarówno mentalnie, jak i finansowo.

Transport publiczny był przez lata postrzegany jako „z założenia” niedochodowy - usługi tego typu świadczyły podmioty państwowe lub samorządowe. Obecnie coraz częściej usługi transportu publicznego świadczą spółki prawa handlowego. I nawet jeżeli są to spółki ze stuprocentowym udziałem lokalnego samorządu, to kierują się rachunkiem ekonomicznym.

Istnieją różne modele zarządzania infrastrukturą tramwajową - przez operatorów lub bez ich udziału. Istnieją także bardzo różne standardy zarówno w zakresie typów, jak i jakości taboru poszczególnych operatorów - stąd porównywanie stawek za wozokilometr pracy przewozowej realizowanej przez różnych operatorów tramwajowych jest obarczone sporym ryzykiem. W przypadku wozokilometra pracy przewozowej w trakcji autobusowej sytuacja jest o tyle łatwiejsza, że z oczywistych względów utrzymanie infrastruktury liniowej pozostaje poza operatorem. Tym samym stawka za wozokilometr de facto jest pochodną wymaganego przez organizatora standardu. W tabeli 3.5 poglądowo wskazano wartości stawek za wozokm w stołecznej komunikacji miejskiej.

$\mathrm{W}$ tabeli zestawiono wszystkich operatorów szynowych obsługujących przewozy w sieci ZTM Warszawa, a także największe kontrakty dotyczące operatorów autobusowych - z zamawianą pracą przewozową $2 \mathrm{mln}$ wozokilometrów lub więcej. Analizując bardziej szczegółowe dane dotyczące wysokości stawek i długości kontraktów także dla mniejszych umów, można zauważyć, że kontrakty o mniejszej wartości (mierząc wolumenem pracy przewozowej) są zwykle zawierane na krótsze terminy. Dodatkowo stawki są tu wyraźnie niższe. $Z$ dwudziestu umów na przewozy autobusowe dziewięć to umowy o ważności 7-8 lat. Sześć z nich zakłada roczną pracę przewozową na poziomie 4 mln wozokilometrów każda, pozostałe $-1,8-2$ mln wozokilometrów. Dla tych dziewięciu umów średnia stawka za wozokilometr to 7,33 zł. Kolejne 11 umów jest zawartych na okresy nie dłuższe niż dwu-, trzyletnie (średnio niecałe 1,5 roku), a średnia stawka za wozokilometr to tutaj 4,92 zł. 
Tabela 3.5. Wysokość stawki za wozokm w sieci Zarządu Transportu Miejskiego w Warszawie

\begin{tabular}{|l|c|c|c|}
\hline Operator & $\begin{array}{c}\text { Okres obowiązywania } \\
\text { umowy (w latach) }\end{array}$ & $\begin{array}{c}\text { Stawka netto za } \\
\text { wozokm }\end{array}$ & $\begin{array}{c}\text { Zamawiana roczna } \\
\text { praca przewozowa } \\
\text { [mln wozokm] }\end{array}$ \\
\hline TW & $2008-2027$ & 16,97 & 50,0 \\
\hline MZA & $2018-2027$ & 9,05 & 86,0 \\
\hline MW & $2009-2027$ & 13,21 & 42,2 \\
\hline SKM & $2010-2024$ & 12,20 & 15,2 \\
\hline Arriva & $2016-2024$ & 7,48 & 4,0 \\
\hline Arriva & $2019-2026$ & 7,45 & 4,0 \\
\hline Michalczewski & $2018-2026$ & 6,67 & 4,0 \\
\hline Mobilis & $2016-2023$ & 7,00 & 4,0 \\
\hline Mobilis & $2016-2023$ & 8,58 & 4,0 \\
\hline Mobilis & $2018-2025$ & 8,05 & 4,0 \\
\hline PKS Grodzisk Maz. & $2017-2024$ & 7,22 & 0,6 \\
\hline WKD & $2009-2021$ & 24,00 & 4,6 \\
\hline Koleje Mazowieckie & $2021-2022$ & 31,85 & \\
\hline
\end{tabular}

Źródło: (Zarząd Transportu Miejskiego w Warszawie, 2021b).

Najwięksi przewoźnicy: Tramwaje Warszawskie, Miejskie Zakładu Autobusowe i Metro Warszawskie, posiadają umowy na wiele lat, o długości odpowiednio: 19,4, 10 i 18,1 lat (Informator ZTM, 2021). Daje się zauważyć, że u operatorów autobusowych stawka operatora komunalnego (MZA) jest wyraźnie wyższa niż stawki operatorów prywatnych.

Można tu zauważyć kilka prawidłowości, obserwowanych także w innych ośrodkach miejskich. Zasadniczo najwięksi przewoźnicy świadczą usługi na podstawie wieloletnich umów. To pozwala efektywniej planować inwestycje związane zarówno $\mathrm{z}$ utrzymaniem infrastruktury (tam gdzie infrastruktura ta występuje), jak i odnową taboru. Siedmio-, ośmioletni okres obowiązywania usług w największych umowach dotyczących komunikacji autobusowej w przybliżeniu odpowiada okresowi, w którym eksploatowane autobusy można uznać za względnie nowe. Umowy o mniejszym dla ZTM znaczeniu (na krótszy okres, z mniejszą liczbą zamawianych wozokilometrów) zwykle dotyczą komunikacji podmiejskiej (aglomeracyjnej).

Z punktu widzenia efektywności realizacji przewozów mierzonej stawką za wozokilometr organizacja przetargów pozwala na obniżenie poziomu kosztów po stronie organizatora transportu, wprowadzając element konkurencji. Z przeprowadzonych badań wynika, że stawka przewoźnika prywatnego jest o około $20 \%$ 
niższa niż stawka operatora komunalnego otrzymującego zamówienie z wolnej ręki i około $8 \%$ niższa niż stawka operatora komunalnego wybranego w przetargu (Wolański, 2011).

Zależności te są potwierdzane w wielu postępowaniach przetargowych. $\mathrm{Na}$ przykład w prowadzonym obecnie przez Zarząd Dróg Miejskich i Komunikacji Publicznej w Bydgoszczy postępowaniu na „świadczenie usług przewozowych na liniach autobusowych w Bydgoszczy w latach 2023-2031" (przetarg obejmuje obsługę 45 brygad autobusowych do 2031 roku) oferta złożona przez najtańszego operatora prywatnego (Mobilis Sp. z o.o.) jest wyraźnie niższa niż oferta przewoźnika komunalnego (Miejskie Zakładu Komunikacyjne w Sp. z o.o.). Operator prywatny zaproponował stawki za wozokilometr w wysokości 7,33 zł za autobus przegubowy i 6,25 zł za autobus krótki, oferta MZK (8,97 zł i 7,50 zł) jest o 20-23\% wyższa (Zarząd Dróg Miejskich i Komunikacji Publicznej w Bydgoszczy, 2021), W tym konkretnym przypadku nie oznacza to jednak, że operator komunalny jest najdroższy - z czterech złożonych ofert jedna była o kilka procent droższa od oferty MZK. W ostatnich latach pojawił się kolejny ciekawy temat związany z powierzaniem obsługi operatorom wybranym w przetargu. Do organizatora należy bowiem określenie wymagań w przetargu - na przykład w zakresie zastosowania paliw alternatywnych. W tabeli 3.5 na przykładzie warszawskiego Zarządu Transportu Miejskiego wskazano między innymi głównych ajentów autobusowych wraz z czasem realizacji umów związanych z obsługą trakcji autobusowej. Dane te pokazują, że jest dziś praktykowane powierzanie obsługi komunikacyjnej na okres 8-9 lat, czyli odpowiadający generalnie większej części cyklu życia pojazdu autobusowego. Wciąż jednak pozostaje pytanie, jaki rodzaj pojazdów powinni wprowadzać do eksploatacji operatorzy prywatni. Autobusy elektryczne (również hybrydowe) wciąż bowiem są produktem na rynku relatywnie nowym i znacząco droższym. W zdecydowanej większości przypadków są kupowane przez operatorów komunalnych, z dofinansowaniem ze środków unijnych.

Niezależnie od tego w polskich miastach do eksploatacji zostały już wprowadzone pierwsze pojazdy $\mathrm{z}$ napędem alternatywnym. Jako przykład może tu posłużyć kontrakt realizowany przez Mobilis dla Zarządu Transportu Miejskiego w Warszawie. W grudniu 2017 roku podpisano umowę, na mocy której Mobilis wprowadził do ruchu na stołecznych ulicach łącznie 61 autobusów hybrydowych MAN, obsługując 50 brygad w komunikacji autobusowej. A jednym z kryteriów oceny ofert była liczba wozów niskoemisyjnych dostarczanych w ramach realizacji zamówienia (Urbanowicz, 2017).

Wraz z upowszechnianiem się pojazdów niskoemisyjnych rodzaj napędu coraz częściej będzie kryterium ocenianym w przetargach na świadczenie usług transportu autobusowego. To wciąż jednak temat stosunkowo nowy. Na przykład w ogłoszonym w 2021 roku dużym przetargu na obsługę komunikacji autobusowej na terenie 
Zarządu Transportu Metropolitalnego w Katowicach jako kryteria oceny ofert wskazano: cenę, wiek pojazdów, klimatyzację przestrzeni pasażerskiej i monitoring, nie akcentując rodzaju napędu. $\mathrm{W}$ wymaganiach wobec pojazdów wykonawców ujęto natomiast, że mogą to być pojazdy z napędem konwencjonalnym lub pojazdy z napędem alternatywnym (Urząd Zamówień Publicznych, 2021). Z analizy dokumentacji wspomnianego przetargu nie wynika, by z powodu zaoferowania pojazdów o napędzie alternatywnym wykonawca miał mieć jakieś korzyści.

Podobne podejście zastosowano $\mathrm{w}$ przetargu na obsługę pakietu linii komunikacji autobusowej w Bydgoszczy, gdzie zamawiający jako kryterium oceny ofert przyjął jedynie cenę. Temat autobusów niskoemisyjnych pojawił się tu w pytaniu zadanym przez jednego z potencjalnych wykonawców. W odpowiedzi zamawiający wskazał, że „Opracowanie, którym aktualnie dysponuje Zamawiający, tzn. analiza kosztów i korzyści wykorzystania autobusów zeroemisyjnych do świadczenia usług komunikacji miejskiej na obszarze Bydgoszczy i gmin ościennych, opracowana zgodnie $\mathrm{z}$ art. 37 ust. 5 ustawy o elektromobilności i paliwach alternatywnych wskazuje w przypadku Bydgoszczy na przewyższenie kosztów nad korzyściami wynikającymi z zakupu taboru o napędzie zeroemisyjnym. W tej sytuacji uwagi Wykonawcy nie są uzasadnione, jak też nieuzasadnione jest stawianie przez Zamawiającego wymogu zakupu autobusów zeroemisyjnych" (Zarząd Dróg Miejskich i Komunikacji Publicznej w Bydgoszczy, 2021). Udzielona odpowiedź jest datowana na 23.07.2021 roku, a termin otwarcia ofert $\mathrm{w}$ tym postępowaniu wyznaczono na 9.11.2021 roku. To pokazuje, że pomimo dyskusji o paliwach alternatywnych i coraz większej liczby autobusów z napędami alternatywnymi argument kosztowy może być dominujący w prowadzonych postępowaniach przetargowych. Powyższe przykłady pokazują zarówno dobre praktyki (ZTM Warszawa), jak i mniej proekologiczne podejście (ZTM Katowice, ZDiKP Bydgoszcz). Obiektywnie należy jednak zwrócić uwagę na fakt, że w Bydgoszczy zadania przetargowe będą mogły być realizowane autobusami spełniającymi normę Euro 6, wyprodukowanymi w 2022 roku, a w Katowicach docelowo także pojazdami z normą Euro 6 (choć należy zauważyć, że w okresie przejściowym dopuszczono także pojazdy spełniające normy Euro 4 i Euro 5). Choć zatem nie wskazano bezpośrednio konieczności posiadania pojazdów o napędzie alternatywnym, określono konkretne normy emisji spalin dla pojazdów z silnikami spalinowymi.

$\mathrm{Z}$ uwagi na wysokie koszty wdrażania nowoczesnych technologii stawianie wymogu zasilania pojazdów paliwami alternatywnymi będzie stanowić ciekawy obszar badawczy w kolejnych latach. Kluczowe będzie tu bowiem umiejętne opisanie wymagań przetargowych - koszty eksploatacji związane z różnymi dostępnymi rodzajami napędu znacząco się różnią, co może uniemożliwić rzetelną ocenę złożonych $\mathrm{w}$ przetargu ofert $\mathrm{w}$ przypadku wykorzystania przez poszczególnych oferentów różnych źródeł napędu. 


\subsection{Innowacje jako katalizator rozwoju rynku}

Wdrażanie nowych rozwiązań zwykle ma pozytywny wpływ na kondycję całego rynku. Dzięki wykwalifikowanej sile roboczej czy elastyczności w działaniu polskie firmy są $\mathrm{w}$ stanie nawiązać walkę z globalnie działającymi producentami, dysponującymi niekiedy znacznie większymi nakładami na badania i rozwój czy szerokim zapleczem finansowym. Na innowacje w transporcie publicznym można więc spojrzeć jako na katalizator rozwoju rynku. Można wskazać wiele przykładów firm, które na innowacyjnych produktach zbudowały markę i pozycję rynkową.

W 2021 roku minęło 25 lat od momentu wyprodukowania pierwszego autobusu miejskiego $\mathrm{w}$ fabryce $\mathrm{w}$ Bolechowie koło Poznania. Był to początek rozwoju i wielkiego międzynarodowego sukcesu firmy Solaris. Rozpoczynając od wprowadzania innowacyjnych (wówczas) autobusów niskopodłogowych, firma ta jest dziś głównym producentem autobusów w Europie. W ciągu 12 miesięcy na ulice europejskich miast wyjechało 1560 autobusów, a niemal $700 \mathrm{z}$ nich posiadało napędy elektryczne. Łącznie Solaris zbudował przez ćwierć wieku ponad 20 tys. pojazdów (Solarisbus.com, 2021).

Jako przykład przedsiębiorstwa intensywnie się rozwijającego posłużyć może firma Ekoenergetyka-Polska powstała w 2009 roku w Zielonej Górze - po dekadzie zatrudnia ona ponad 300 pracowników i ma klientów w całej Europie. Od początku celem firmy jest tworzenie infrastruktury ładowania dla pojazdów elektrycznych (Ekoenergetyka.pl, 2021). Rozwój Ekoenergetyki jest nierozerwalnie związany $\mathrm{z}$ trendami w zakresie elektromobilności.

Przykładem przedsiębiorstwa, które konsekwentnie buduje swoją pozycję międzynarodową na rynku komponentów do pojazdów dla komunikacji publicznej, jest też firma Medcom - choć polski producent jest znany przede wszystkim z produkcji komponentów (na przykład przetwornic) do pojazdów szynowych, to ma też w portfolio gamę produktów dla autobusów miejskich. A wraz z kolejnymi kontraktami międzynarodowymi i rozwojem rynków zarówno dla pojazdów szynowych, jak i autobusów elektrycznych firma dalej się rozwija (Raportkolejowy.pl, 2018).

Wskazane powyżej trzy przykłady są nieprzypadkowe - są to producenci, których wyroby są względem siebie komplementarne. Nie ma autobusu elektrycznego bez infrastruktury i odpowiedniego osprzętu. Tym samym rozwój jednego przedsiębiorstwa na rynku może prowadzić do rozwoju kolejnych firm.

Podobną drogą próbuje pójść także poznańska firma Modertrans - opierając przekaz marketingowy i handlowy właśnie na innowacyjności swoich pojazdów. Jako elementy innowacyjne wskazywane są między innymi innowacyjny układ napędowy zbudowany na bazie tranzystorów wykonanych z węglika krzemu (SiC), silniki trakcyjne o zmniejszonych gabarytach, elektromagnetyczny hamulec postojowy czy system odzysku energii podczas hamowania (Modertrans, 2021). 


\section{INNOWACJE W FUNKCJONOWANIU OPERATORA I ORGANIZATORA TRANSPORTU PUBLICZNEGO}

Należy zwrócić uwagę, że przytoczona w rozdziale 3 definicja publicznego transportu zbiorowego nakazuje nie ograniczać się tylko do transportu w miastach i aglomeracjach. Tym samym, mając na uwadze formy i sposoby organizacji transportu na poziomie wojewódzkim czy krajowym, należy zwrócić uwagę także na specyficzne dla tych form transportu innowacje. Zatem podmiotem wdrażającym innowacje może stać się zarządca infrastruktury działający na przykład na poziomie krajowym. Tak jest chociażby w transporcie kolejowym.

\subsection{Katalog stosowanych innowacji}

Istnieje wiele grup innowacji. Celem niniejszego podrozdziału jest $\mathrm{z}$ jednej strony zbiorcze zestawienie poszczególnych elementów, z drugiej - przedstawienie próby autorskiego klasyfikowania innowacji $\mathrm{w}$ transporcie publicznym - na podstawie przeprowadzonego przeglądu literatury, obecnych w praktyce gospodarczej i systemach transportowych rozwiązań oraz wielopłaszczyznowej i wielokryterialnej analizy rynku.

Innowacje stosowane $\mathrm{w}$ transporcie publicznym możemy podzielić $\mathrm{z}$ uwagi na cztery podstawowe kryteria.

\section{Podmiot wdrażający}

Podmiotem wdrażającym innowację może być: organizator transportu, operator, miasto, inny podmiot, na przykład przedsiębiorca prywatny lub też zarządca infrastruktury. Może występować także relacja - na przykład gdy innowację wprowadza operator, ale na polecenie (chociażby określone wymagania przetargowe) organizatora.

\section{Zasięg oddziaływania}

Zasięg oddziaływania innowacji można rozpatrywać na dwóch podstawowych płaszczyznach: wewnętrznej i zewnętrznej oraz pośredniej i bezpośredniej. 
Z uwagi na sposób oddziaływania wewnątrz systemu transportu publicznego innowacje mogą oddziaływać na organizatora transportu publicznego, operatora transportu publicznego lub większą liczbę operatorów. Możliwa jest także sytuacja, w której innowacja oddziałuje na usługodawcę zewnętrznego (lub usługodawcę we współpracy z organizatorem), organizatora we współpracy z operatorem czy podmioty budujące system transportowy w innym układzie. We wszystkich wskazanych przypadkach mowa o oddziaływaniu bezpośrednim, ponieważ system transportu publicznego stanowi system naczyń połączonych, zwykle towarzyszy temu oddziaływaniu także oddziaływanie pośrednie na inne podmioty tworzące ten system.

Poszczególne innowacje mogą mieś charakter wewnętrzny, oddziałując tylko i wyłącznie na podmioty zajmujące się transportem publicznym od strony podażowej. W ich bezpośrednim zasięgu pozostają wówczas: administracja samorządowa, organizator transportu (na szczeblu metropolii, aglomeracji, miasta itd.), operator lub operatorzy - jako podmioty świadczące usługi transportowe - czy też inni usługodawcy (na przykład zewnętrzni dostawcy usług). Druga potencjalna sytuacja to taka, gdy stosowana innowacja ma charakter zewnętrzny - oddziałuje przede wszystkim na klienta końcowego korzystającego z usługi transportu publicznego, który jest głównym beneficjentem tejże innowacji.

W przypadku gdy dana branża (na przykład transport kolejowy, śródlądowy itd.) posiada swojego zarządcę - to on może być wdrażającym innowacje lub korzystającym z nich. Jest też możliwa sytuacja, w której wprowadzona innowacja oddziałuje zarówno na klienta, jak i na świadczoną usługę (bezpośrednio na klienta lub niebezpośrednio).

\section{Rodzaj innowacji}

Trzecim kryterium klasyfikacji innowacji jest jej rodzaj. W pierwszych dwóch rozdziałach wskazano wiele klasyfikacji i rodzajów innowacji, w tym miejscu można ograniczyć klasyfikację do czterech podstawowych: produktowej, procesowej, technicznej i organizacyjnej (marketingowej).

\section{Kosztochłonność i kosztogenność}

Kosztochłonność i kosztogenność w odniesieniu do systemów transportu publicznego można traktować jako kryterium oceny wpływu danej innowacji na koszty funkcjonowania systemu transportu publicznego. Zjawiska te można także analizować z punktu widzenia kosztów dla użytkownika końcowego - jako innowacje generujące dodatkowy strumień przychodów z punktu widzenia systemu transportu publicznego.

Tu pojawia się też w naturalny sposób pytanie: Kto powinien finansować innowacje i czy występuje ryzyko „przerzucenia” kosztów innowacyjności na użytkownika końcowego? Odpowiedź znajduje się w podrozdziałach, w których omówiono efektywność ekonomiczną. 


\subsection{Wybrane innowacje w transporcie publicznym - klasyfikacja}

Innowacje w transporcie publicznym dotyczą między innymi funkcjonalności pojazdów komunikacji publicznej. Rolą komunikacji publicznej jest zapewnienie mobilności w odpowiednim standardzie jakościowym. Drugi ważny element to wpływ transportu publicznego na środowisko naturalne - stąd najbardziej popularne napędy alternatywne dla pojazdów komunikacji publicznej z krótkim opisem.

Digitalizacja procesów dotarła do transportu publicznego, czego efektem jest przedstawienie podstawowych grup systemów informatycznych - zarówno w ujęciu operatora, jak i organizatora transportu. Kolejne podrozdziały poświęcono mobilności indywidualnej i jej miejscu w transporcie publicznym, a także dwóm kolejnym grupom innowacji: organizacyjnym i produktowo-procesowym, związanym $\mathrm{z}$ wdrażaniem innowacyjnych środków transportu.

Zakres innowacji stosowanych $\mathrm{w}$ transporcie publicznym jest niezwykle szeroki - w niniejszej publikacji nie uda się na pewno wymienić wszystkich. W tym rozdziale stworzono ich możliwie kompleksowy katalog celem szerokiego i możliwie kompletnego spojrzenia na analizowaną problematykę, a także późniejsze ich zaklasyfikowanie - zgodnie z wcześniej zdefiniowanymi kryteriami podziału.

Mnogość dobrych praktyk w zakresie komunikacji publicznej nakazuje też się zastanowić, w jaki sposób można analizować te rozwiązania. W tym miejscu warto zaproponować także odniesienie do modelu referencyjnego logistyki miejskiej, który zaprezentowali Kiba-Janiak i Witkowski (2014). Wskazują oni, że rozwiązania transportu publicznego mogą być analizowane z trzech perspektyw - w odniesieniu do poziomu oczekiwań mieszkańców (niski, średni, wysoki), rodzaju strumienia (indywidualny i zbiorowy osób, ładunków informacji) oraz kosztochłonności (nisko-, średnio- i wysokokosztowe rozwiązania racjonalizujące system). Koncepcja ta odnosi się co prawda do szerszego kontekstu modelowania logistyki miejskiej, może jednak znaleźć zastosowanie także do oceny i usystematyzowania innowacji $\mathrm{w}$ transporcie publicznym.

Wprowadzeniem do poniższych podrozdziałów jest tabela 4.1. Zawarto w niej innowacje opisywane $\mathrm{w}$ dalszych podrozdziałach wraz $\mathrm{z}$ próbą przypisania do konkretnych kryteriów klasyfikacji, wraz z krótkim komentarzem. Na podstawie tej tabeli można przedstawić kilka wniosków.

Innowacje o charakterze technicznym (i/lub informatycznym) są zwykle związane z ponoszeniem średnich lub dużych nakładów - oczywiście w zależności od skali wdrożenia (a w przypadku systemów informatycznych - skali rozwiązania). $\mathrm{Z}$ kolei grupy związane $\mathrm{z}$ innowacjami organizacyjnymi i procesowymi są na tyle 
szerokie, że bardzo trudno byłoby jednoznacznie zaklasyfikować wskazywane rozwiązania do konkretnych wartości danego kryterium.

Tabela 4.1. Klasyfikacja innowacji według wybranych kryteriów

\begin{tabular}{|c|c|c|c|c|}
\hline Nazwa innowacji & $\begin{array}{c}\text { Podmiot } \\
\text { wdrażający }\end{array}$ & $\begin{array}{c}\text { Zasięg } \\
\text { oddziaływania }\end{array}$ & Rodzaj innowacji & $\begin{array}{l}\text { Kosztochłonność } \\
\text { i kosztogenność }\end{array}$ \\
\hline $\begin{array}{l}\text { Urządzenia } \\
\text { pokładowe } \\
\text { wpływające na } \\
\text { komfort jazdy }\end{array}$ & $\begin{array}{l}\text { operator, także } \\
\text { na zlecenie } \\
\text { organizatora }\end{array}$ & $\begin{array}{l}\text { zewnętrzny, } \\
\text { bezpośredni }\end{array}$ & $\begin{array}{l}\text { produktowa, } \\
\text { techniczna }\end{array}$ & mała i średnia \\
\hline $\begin{array}{l}\text { Pojazdy } \\
\text { autonomiczne }\end{array}$ & $\begin{array}{l}\text { operator, także } \\
\text { na zlecenie } \\
\text { organizatora }\end{array}$ & $\begin{array}{l}\text { zewnętrzny, } \\
\text { bezpośredni }\end{array}$ & $\begin{array}{l}\text { produktowa, } \\
\text { techniczna }\end{array}$ & duża \\
\hline $\begin{array}{l}\text { Napędy } \\
\text { alternatywne }\end{array}$ & $\begin{array}{l}\text { operator, także } \\
\text { na zlecenie } \\
\text { organizatora } \\
\end{array}$ & $\begin{array}{l}\text { zewnętrzny, } \\
\text { bezpośredni }\end{array}$ & $\begin{array}{l}\text { produktowa, } \\
\text { techniczna }\end{array}$ & średnia i duża \\
\hline $\begin{array}{l}\text { Systemy } \\
\text { informatyczne }\end{array}$ & $\begin{array}{l}\text { operator lub } \\
\text { organizator }\end{array}$ & $\begin{array}{l}\text { zewnętrzny lub } \\
\text { wewnętrzny, } \\
\text { bezpośredni lub } \\
\text { pośredni }\end{array}$ & $\begin{array}{l}\text { produktowa, } \\
\text { techniczna, } \\
\text { procesowa, } \\
\text { organizacyjna }\end{array}$ & \begin{tabular}{|l} 
zależna od \\
skali wdrożenia \\
i rodzaju \\
rozwiązania
\end{tabular} \\
\hline $\begin{array}{l}\text { Systemy } \\
\text { mobilności } \\
\text { indywidualnej }\end{array}$ & $\begin{array}{l}\text { organizator, } \\
\text { podmiot } \\
\text { prywatny } \\
\text { na zlecenie } \\
\text { organizatora }\end{array}$ & $\begin{array}{l}\text { zewnętrzny, } \\
\text { bezpośredni lub } \\
\text { pośredni }\end{array}$ & $\begin{array}{l}\text { produktowa, } \\
\text { techniczna, } \\
\text { procesowa, } \\
\text { organizacyjna }\end{array}$ & średnia i duża \\
\hline $\begin{array}{l}\text { Wybrane } \\
\text { innowacje } \\
\text { organizacyjne }\end{array}$ & $\begin{array}{l}\text { operator, } \\
\text { organizator, inny } \\
\text { podmiot }\end{array}$ & \begin{tabular}{|l|} 
zewnętrzny lub \\
wewnętrzny, \\
bezpośredni lub \\
pośredni \\
\end{tabular} & $\begin{array}{l}\text { procesowa, } \\
\text { organizacyjna }\end{array}$ & \begin{tabular}{|l|} 
zależna od \\
skali wdrożenia \\
i rodzaju \\
rozwiązania
\end{tabular} \\
\hline $\begin{array}{l}\text { Innowacyjne } \\
\text { środki transportu }\end{array}$ & $\begin{array}{l}\text { operator, także } \\
\text { na zlecenie } \\
\text { organizatora }\end{array}$ & $\begin{array}{l}\text { zewnętrzny, } \\
\text { bezpośredni }\end{array}$ & $\begin{array}{l}\text { produktowa, } \\
\text { techniczna }\end{array}$ & średnia i duża \\
\hline
\end{tabular}

Można zatem postawić tezę, że zasięg stosowanych w transporcie publicznym innowacji jest na tyle szeroki, że nie da się jednoznacznie zaklasyfikować wszystkich opisanych rozwiązań do stricte jednej grupy. A chcąc dokonać czytelnej i dokładnej klasyfikacji, należałoby zejść poziom niżej i analizować konkretne wdrożenia konkretnych technologii i rozwiązan - w wybranym przedsiębiorstwie, horyzoncie czasowym, a najlepiej z dokładnością do pojedynczych i wyraźnie zaznaczonych chociażby budżetem projektów. 


\subsection{Innowacje dotyczące funkcjonalności pojazdów komunikacji publicznej}

Wśród elementów i nowoczesnych rozwiązań technicznych, które coraz częściej znajdują się w wyposażeniu pojazdów komunikacji miejskiej, są:

- klimatyzacja,

- ładowarki USB,

- dedykowane miejsca przewozu rowerów,

- rampy dla niepełnosprawnych,

- systemy pokładowe informacji pasażerskiej,

- systemy dynamicznej informacji pasażerskiej,

- systemy informacji miejskiej/reklamowej.

Procentowy udział tych elementów wyposażenia $\mathrm{z}$ roku na rok rośnie. $\mathrm{Z}$ danych Izby Gospodarczej Komunikacji Miejskiej wynika, że wyposażenie pojazdów w 2019 roku przedstawiało się tak jak zobrazowano na rysunku 4.1:

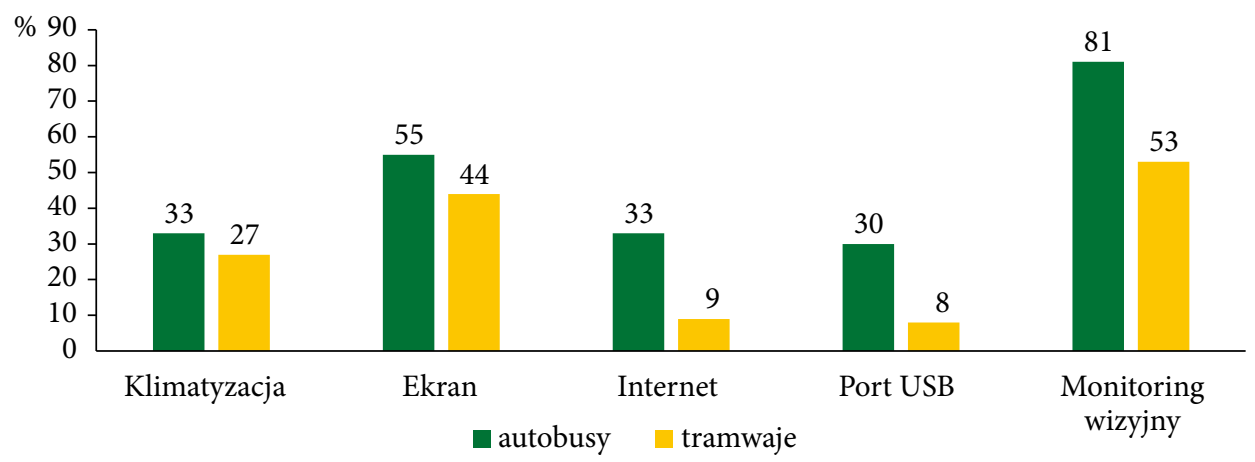

Rysunek 4.1. Wyposażenie autobusów i tramwajów w udogodnienia dla pasażerów

Źródło: (Izba Gospodarcza Komunikacji Miejskiej, 2021).

Podobnie jak inne grupy pojazdów tak i autobusy miejskie charakteryzują się określonym cyklem życia produktu. W praktyce oznacza to, że wprowadzony na rynek pojazd po kilku latach musi ustąpić miejsca nowszej generacji. To sprawia, że producenci regularnie promują nowe modele, a wraz z nimi - wprowadzone innowacje. W poniższym zestawieniu skupiono się na elementach wyposażenia wpływających na komfort jazdy pasażerów, akcentowanych przez producentów najliczniej sprzedających się na polskim rynku marek: Solaris, Mercedes-Benz i MAN (infobus.pl, 2019b). Autobus miejski posiadający tzw. niską podłogę na całej zielone 
słupki zamiast niebieskichdługości jest dziś w polskich miastach niemal standardem. Nic zatem dziwnego, że producenci akcentują inne elementy wyposażenia, które mają stanowić o atrakcyjności i wysokiej jakości pojazdu oraz oferowanych w nim warunkach pracy (dla kierowcy) i podróżowania (dla pasażerów).

W katalogu autobusów miejskich Solaris Urbino z napędem konwencjonalnym producent wskazuje wśród elementów wpływających na komfort między innymi klimatyzację przestrzeni pasażerskiej z napędem mechanicznym lub elektrycznym (jako wyposażenie opcjonalne) oraz rampę inwalidy (odkładaną ręcznie w wyposażeniu standardowym, a opcjonalnie elektryczną). W wyposażeniu standardowym autobusów znajdziemy dwukierunkowe wentylatory, elektryczne szyberdachy czy nagrzewnice dwustopniowe i grzejniki konwektorowe (solarisbus.com, 2018).

Sporo uwagi opisowi „komfortu” poświęca producent autobusów Mercedes. Charakteryzując popularny model miejskiego autobusu Citaro, producent zwraca uwagę między innymi na duże okna panoramiczne, wykończenie dachu podsufitką, ergonomiczne ukształtowanie siedzeń i zróżnicowany system poręczy zapewniający pewne oparcie oraz nowy kształt przycisków „przystanku na żądanie”, łatwiejszych do odnalezienia zwłaszcza dla osób niedowidzących (mercedes-benz.com, 2021).

Nowa generacja autobusów MAN Lion's City promowana jest jako „perfekcyjne autobusy miejskie". Producent akcentuje ekonomię eksploatacji, stosowane innowacje techniczne i elementy wpływające na komfort jazdy (przede wszystkim kierowcy, ale także pasażerów). Wśród elementów wpływających na wygodę pasażerów producent wskazuje między innymi dyskretne oświetlenie LED w przedziale pasażerskim z możliwością ściemniania. Światło to, padając z góry, ma być bardziej naturalne dla podróżujących (bus.man.eu, 2021). Wśród nowości w przestrzeni pasażerskiej są także nowe wsporniki foteli i inny sposób montażu siedzeń (na bocznych szynach), a także nowe, bardziej ekonomiczne uchwyty o owalnym przekroju (infobus, 2019a).

Zakupem fabrycznie nowych autobusów charakteryzuje się na przykład polityka taborowa MPK Poznań sp. z o.o. Wraz z kolejnymi seriami autobusów coraz bogatsze staje się ich wyposażenie. Są to także elementy bezpośrednio wpływające na komfort jazdy pasażerów, stanowiące odpowiedź na zgłaszane przez klientów MPK potrzeby.

Pierwszym, niezwykle ważnym elementem było wprowadzenie do ruchu autobusów niskopodłogowych. Pierwszy taki pojazd pojawił się w 1995 roku, rok później do eksploatacji włączono flotę autobusów MAN i Neoplan. Za „niskopodłogowy” uznawano wówczas pojazd dysponujący niską podłogą w części pojazdu (w późniejszym okresie takie pojazdy określano mianem częściowo niskopodłogowych lub niskowejściowych). Wraz z kolejnymi zakupami podnoszono także kwestię ekologii - kolejne generacje autobusów spełniały coraz bardziej restrykcyjne normy emisji spalin. Pierwszym etapem obniżania emisji spalin było rozpoczęcie w 1995 roku wykorzystania ekologicznego oleju napędowego (Wojcieszak, 2000).

Kolejną rewolucją było pojawienie się w Poznaniu pierwszych autobusów z klimatyzacją. W autobusach Solaris (a także i MAN) dostarczonych w 2006 roku po raz 
pierwszy pojawiła się klimatyzacja przestrzeni pasażerskiej, autobusy wyposażono także w monitoring (wewnętrzny, a dodatkową nowością była kamera cofania) (Jurczak, 2006a). Zakupy taboru poczynione w 2006 roku pozwoliły na wycofanie z eksploatacji autobusów wysokopodłogowych, między innymi marki Ikarus z lat 1985-1990 (Jurczak, 2006b).

Kolejnym etapem podwyższania poziomu wyposażenia autobusów miejskich była dostawa autobusów Solaris Urbino w 2009 roku. Po raz pierwszy zdecydowano się wówczas na wyposażenie autobusów w automaty biletowe - co miało stanowić wyraźne ułatwienie dla pasażerów, zwłaszcza w tych obszarach miasta, gdzie dostęp do tradycyjnej sieci sprzedaży był mocno utrudniony. Autobusy posiadały także drzwi odskokowo-uchylne (po raz pierwszy takie rozwiązanie pojawiło się w autobusach MPK rok wcześniej). Wśród nowości (w mniejszym stopniu powiązanych z potrzebami pasażerów) były także: kamera rejestrująca obraz przed pojazdem, elektroniczne wyświetlacze informujące o numerze kursu na danej linii czy system gaszący w komorze silnika (MPK Poznań, 2009). Dwa lata później, w 2011 roku, wraz kolejną dostawą autobusów miejskich (MPK Poznań, 2021) w wyposażeniu znalazły się między innymi duże monitory pokładowego systemu informacji pasażerskiej, co pozwoliło na przekazywanie znacznie większej ilości informacji pasażerom niż wcześniej.

Kolejną nowością funkcjonalną w autobusach MPK w odpowiedzi na potrzeby zgłaszane przez pasażerów było pojawienie się portów USB, dzięki którym można naładować urządzenia mobilne (MPK Poznań, 2016). Autobusy dostarczone do MPK w 2016 roku posiadały także uchwyty do montowania i przewożenia rowerów, dodatkowe wyświetlacze boczne z numerem linii czy system liczenia pasażerów. $\mathrm{W}$ pojazdach zastosowano między innymi energooszczędne oświetlenie i komplet zewnętrznych tablic informacyjnych w technologii LED (co ma poprawić czytelność tablic) oraz znany już wcześniej wewnętrzny monitor LCD. Kolejną partię autobusów zamówiono jesienią 2017 roku, a wśród nowości bezpośrednio wpływających na komfort jazdy pasażerów są między innymi informacje w alfabecie Braille’a. Jest to ułatwienie dla osób niewidomych i niedowidzących, zachęcające niepełnosprawnych do podróży środkami miejskiej komunikacji (MPK Poznań, 2017). Autobusy są wprowadzane do ruchu od 2018 roku.

\subsection{Pojazdy autonomiczne}

Za innowację $\mathrm{w}$ transporcie publicznym można także z powodzeniem uznać pojazdy autonomiczne. Pojazdy autonomiczne są zjawiskiem stosunkowo nowym, pozostają wyzwaniem nie tylko w sferze technologii i organizacji ruchu, ale także porządku prawnego. Jaki pojazd możemy uznać za autonomiczny? Definicji tego 
pojęcia jest bardzo wiele, a w zależności od przyjętej definicji poszczególne rozwiązania stosowane $\mathrm{w}$ transporcie publicznym można uznać za autonomiczne bądź też nie.

Obecnie wszyscy mają świadomość potencjału, jaki niesie ze sobą wprowadzenie pojazdów autonomicznych. Nikt nie wie jednak, jak bardzo zmienią one kształt systemów transportowych i miast samych w sobie (Maurer, Gerdes, Lenz i Winner, 2016).

Ustawa Prawo o ruchu drogowym w art. 65k definiuje: „Ilekroć w niniejszym oddziale jest mowa o pojeździe autonomicznym, należy przez to rozumieć pojazd samochodowy, wyposażony w systemy sprawujące kontrolę nad ruchem tego pojazdu i umożliwiające jego ruch bez ingerencji kierującego, który w każdej chwili może przejąć kontrolę nad tym pojazdem" (Ustawa PoRD, 2021, s. 82). W ustawie pojawiają się zapisy określające ruch pojazdów jako "prace badawcze”. Zgodnie $\mathrm{z}$ art. 651 „Prowadzenie prac badawczych związanych $\mathrm{z}$ testowaniem pojazdów autonomicznych w ruchu drogowym na drogach publicznych, w szczególności na potrzeby zastosowania pojazdów autonomicznych $\mathrm{w}$ transporcie zbiorowym i realizacji innych zadań publicznych, jest możliwe pod warunkiem spełnienia wymagań bezpieczeństwa i uzyskania zezwolenia na przeprowadzenie tych prac" (Ustawa PoRD, 2021, s. 82). W praktyce, biorąc pod uwagę definicję pojazdu samochodowego zawartego w powyższej ustawie, za pojazd autonomiczny można uznać pojazd silnikowy, którego konstrukcja umożliwia jazdę z prędkością przekraczającą $25 \mathrm{~km} / \mathrm{h}$, posiadający możliwość ruchu bez ingerencji kierującego.

Na przykład, Choromański, Grabarek, Kozłowski, Czerepicki i Marczuk (2020, s. 11) definiują pojazd autonomiczny jako taki, który posiada dwie podstawowe cechy: po pierwsze „kieruje samodzielnie, czasowo lub ciągle, tzn. eliminuje całkowicie lub częściowo udział kierowcy”, a po drugie „pozwala na inteligentny wybór trasy (w zależności od celu podróży) oraz wykonanie manewrów (adekwatnych do aktualnej sytuacji na drodze. Zdaniem cytowanych autorów taka definicja (podobnie jak inne definicje) może również zostać uznana za niedoskonałą - chociażby z powodu nieuznania za pojazd autonomiczny tramwaju bez motorniczego (bo pojazd ten zasadniczo nie wykonuje „manewrów”).

Rozwiązania w zakresie autonomii transportu publicznego można podzielić na kilka podstawowych grup. Jako standard branżowy uznaje się tu klasyfikację National Highway Trafic Safety Administration - amerykańskiej agencji stanowiącej część departamentu transportu (rysunek 4.2).

Autonomię ruchu ocenia się na sześciu poziomach - od zera (brak autonomii) do 5 (pełna autonomia). Kolejne poziomy oznaczają coraz większe możliwości autonomicznego prowadzenia ruchu, stopniowo wyłączające odpowiedzialność prowadzącego pojazd za kolejne funkcje. Powyższa klasyfikacja odnosi się do transportu drogowego. 


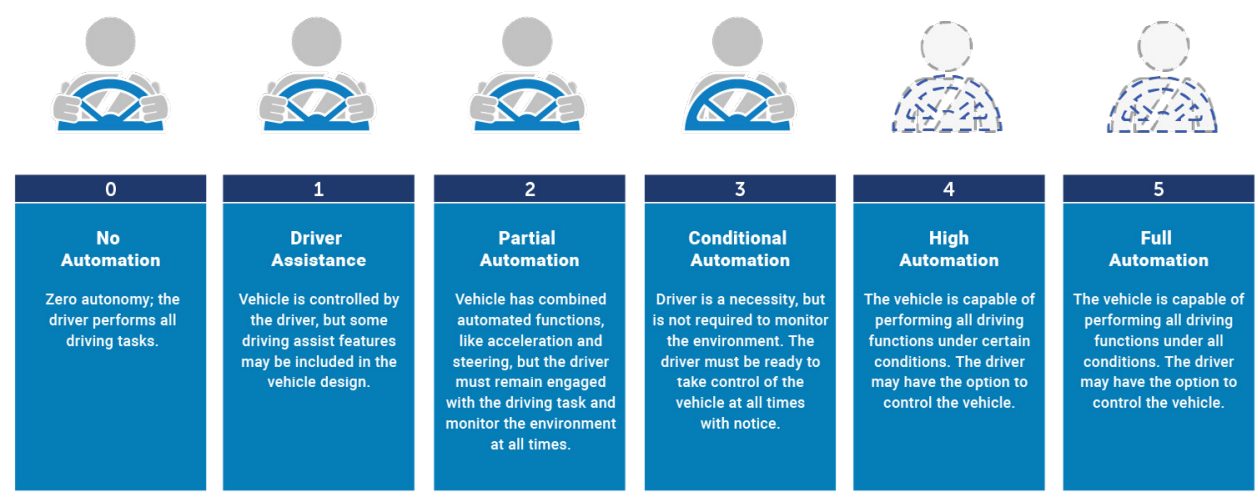

Rysunek 4.2. Klasyfikacja autonomii ruchu według NHTSA

Źródło: (NHTSA, 2021).

O ile w przypadku pojazdów szynowych można spotkać wiele sprawnie funkcjonujących autonomicznych systemów transportowych (chociażby linii metra), o tyle znacznie ciekawsza wydaje się perspektywa drogowych pojazdów tego typu. Dynamika ruchu drogowego sprawia, że autonomia ruchu jest tu niesamowitym wyzwaniem technicznym i organizacyjnym. Tym ważniejsze są zatem wszelkie próby stworzenia funkcjonujących rozwiązań w tym zakresie.

Jako przykład może tu posłużyć między innymi projekt HEAT realizowany w mieście Hamburg (rysunek 4.3). Projekt pod nazwą HEAT - Hamburg Electric Autonomous Transport to projekt badawczo-rozwojowy między innymi miejskiego przewoźnika transportu publicznego HOCHBAHN. Celem jest sprawdzenie możliwości realizacji przewozów pojazdem autonomicznym jako sposobu na tworzenie nowych, bardziej elastycznych form mobilności. Projekt jest realizowany od 2019 roku. Na pierwszym etapie rozpoczęto testy pojazdu bez pasażerów, z maksymalną prędkością $15 \mathrm{~km} / \mathrm{h}$. Na drugim etapie zakłada się zwiększenie prędkości do $25 \mathrm{~km} / \mathrm{h}$ i kursy z pasażerami. Pojazd autonomiczny kursuje specjalnie wyznaczoną trasą o długości 1,8 km. Biegnie ona przez obszar portu w Hamburgu i ma pięć przystanków. Projekt HEAT ma kilka podstawowych celów: sprawdzenie, czy autonomiczne minibusy mogą spełniać swoją funkcję w budowaniu publicznego systemu transportowego i zapewnić wsparcie do innych form transportu oferowanego przez HOCHBAHN, ale także zebranie doświadczeń z pierwszej ręki - bezpośrednio od pasażerów korzystających z nowej formy realizacji usług transportowych. HEAT ma doprowadzić także do zdefiniowania wymagań dla technologii pojazdów i infrastruktury drogowej. A to wszystko razem ma sprawić, że zaufanie do technologii autonomicznych w przyszłości będzie większe (Hochbahn.de, 2021). Partnerami projektu są między innymi instytucje i firmy branżowe. 


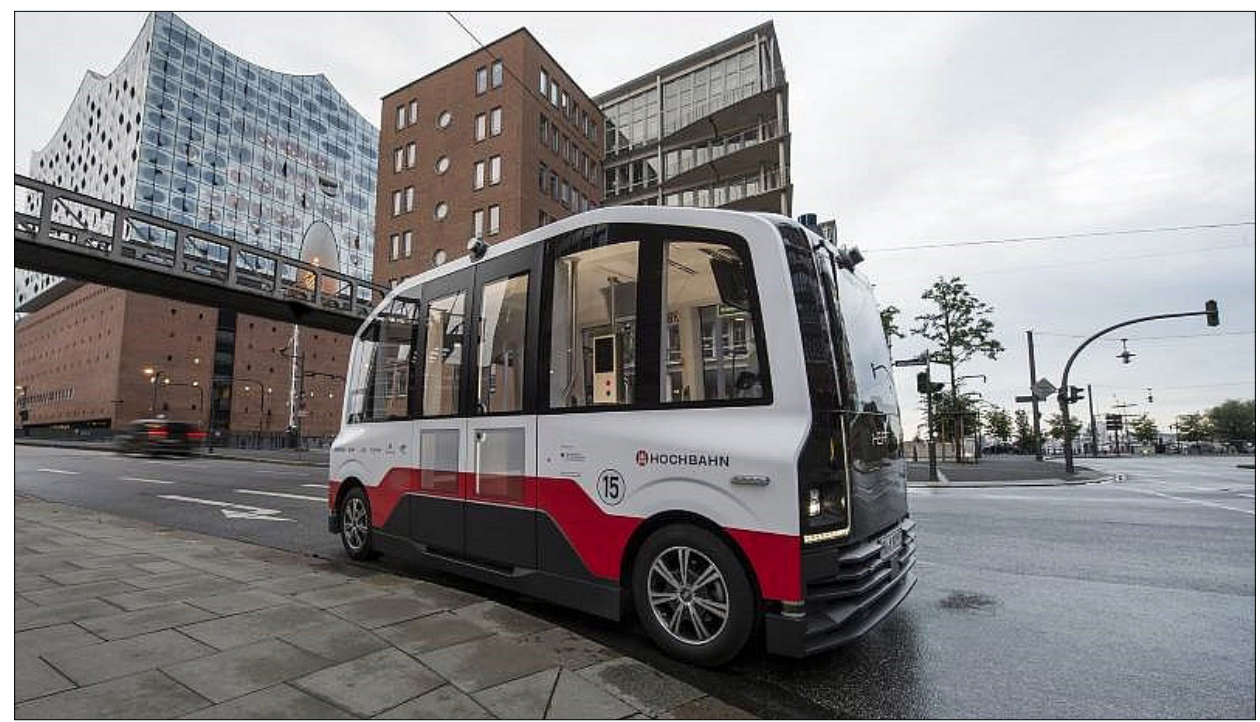

Rysunek 4.3. Pojazd autonomiczny projektu HEAT

Źródło: (Heat, 2021).

W październiku 2020 roku minibus przewiózł pierwszych pasażerów. Na samym początku pojazdem mogły podróżować maksymalnie trzy osoby, do tego dwóch członków obsługi. To pierwsze takie testy - pojazdu autonomicznego z pasażerami, na publicznej drodze. Oficjalnie pojazd zaprezentowano na ITS World Congress w Hamburgu w październiku 2021 roku. Specjaliści komentują, że to wielki krok w mobilności miejskiej. Infrastruktura drogowa i integracja z zewnętrznymi systemami to zadanie, które realizuje w projekcie Siemens Mobility. Rolą HOCHBAHN było między innymi dostarczenie wysokiej rozdzielczości map, które obrazują trasę przejazdu praktycznie co do centymetrów. A celem wprowadzenia takich pojazdów do ruchu ma być między innymi zapewnienie nowego rodzaju usług wszędzie tam, gdzie większe pojazdy byłyby niepraktyczne - poza godzinami szczytu czy w obszarach poza centrum miast (Hill, 2020).

Testy pojazdu autonomicznego są także prowadzone w Szwecji. W styczniu 2021 roku rozpoczęły się testy w Goeteborgu. Projekt nazwany „S3, Shared Shuttle Services” jest częścią programu „Next Generation travel and transport” realizowanego wspólnie z rządem. Testy pojazdu w ruchu są kolejnym etapem projektu. Dwa autonomiczne minibusy kursują pomiędzy przystankiem „Hugo Hammars Kaj”, gdzie znajduje się duży parking samochodowy, a Regnbågsgatan - dużym węzłem transportu publicznego. Liderem projektu jest firma RISE (Chalmers.se, 2021).

Z kolei już ponad 300 pasażerów przejechało ponad 1000 kilometrów (stan na dzień 13.07.2021 roku) autonomicznym minibusem dookoła uniwersytetu w Cambridge (rysunek 4.4). Automatyczny pojazd kursuje z Madingley Park\&Ride od 
czerwca 2021 roku, aby sprawdzić możliwość wykorzystania pojazdów autonomicznych w transporcie publicznym do potencjalnego zastosowania w przyszłości. To pierwszy przypadek w Wielkiej Brytanii, gdy autonomiczny pojazd (w dodatku tak mocno „personalizowany“) dzieli ulicę z „normalnym “ ruchem drogowym w trakcie regularnych przewozów pasażerskich. Każdy przejazd ze względów bezpieczeństwa odbywa się z obsługą dwóch operatorów, którzy są gotowi do przejęcia kontroli nad pojazdem, gdyby wystąpiła taka konieczność. Pasażerowie są ankietowani, pod kątem odczuć związanych z podróżą. Ponad 97\% przewiezionych pasażerów mówi, że wsiadłoby do takiego pojazdu ponownie, bez zawahania. Cały projekt jest prowadzony przez Greater Cambridge Partnership, Smart Camdridge i inżynierów z firmy Aurrigo. Celem takich testów jest stworzenie możliwości dla regularnej eksploatacji tego typu pojazdów jako transportu publicznego dostarczanego według zapotrzebowania („na życzenie“) (Greatercampridge.co.uk, 2021).

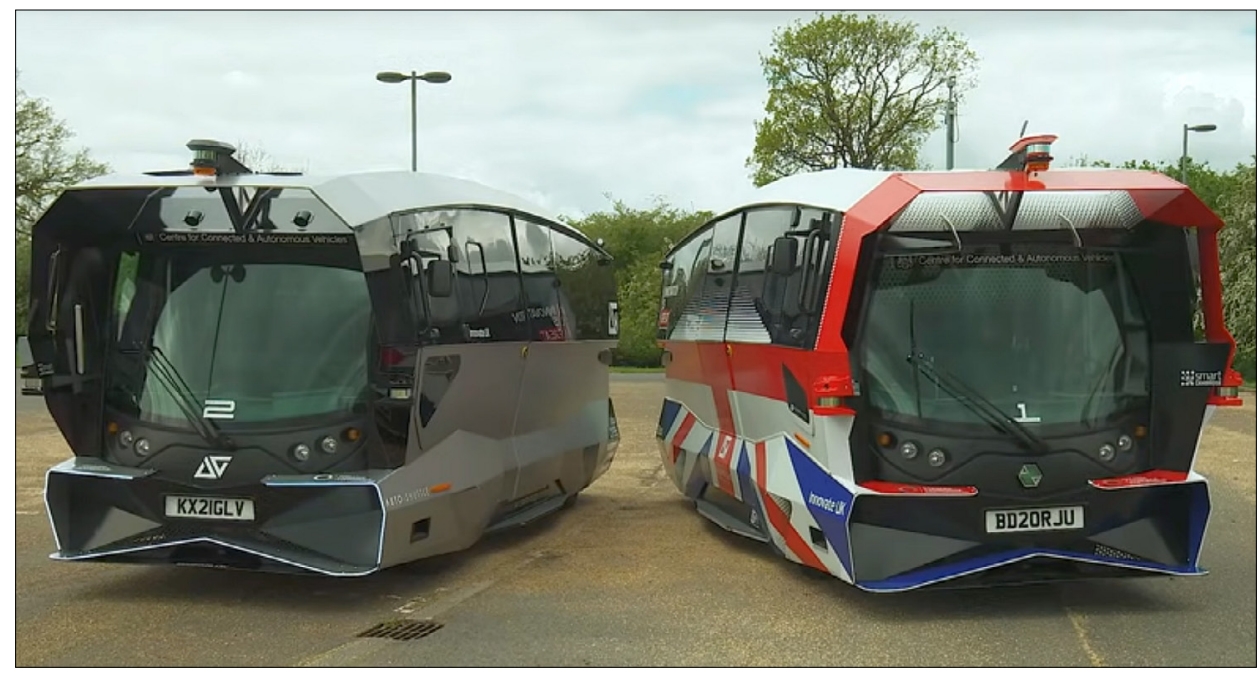

\section{Rysunek 4.4. Pojazd autonomiczny projektu Cambridge}

Źródło: (GreaterCambridge.org.uk, 2021).

Malaga ogłosiła się pierwszym miastem testującym w ruchu pasażerskim „pełnowymiarowy" autobus miejski. 12-metrowy pojazd na pierwszy rzut oka wygląda tak jak inne autobusy miejskie - za kierownicą siedzi kierowca, sprzedaje bilety. $\mathrm{W}$ praktyce jednak rola kierowcy jest ograniczona - nie naciska on pedału przyspieszenia i nie kręci kierownicą, a autobus porusza się samodzielnie - wykorzystuje się w nim czujniki, kamery i technologię GPS. Analiza otoczenia w czasie rzeczywistym pozwala na automatyczną reakcję - na przykład w razie wtargnięcia pieszego na jezdnię. Innowacyjny projekt prowadzą: firma transportowa Avanza i miasto Malaga. Władze miasta są dumne z projektu - wskazując, że to pierwsze testy „praw- 
dziwego", dużego autobusu w rzeczywistym ruchu miejskim. W 2021 roku testowe przejazdy autobusów elektrycznych bez kierowcy uruchomiono także w Singapurze (McMurtry, 2021).

W styczniu 2021 roku Chiny ogłosiły wprowadzenie nowych regulacji prawnych, co pozwoli na testy pojazdów autonomicznych na publicznych autostradach. Czterokilometrowy tor testowy dla autonomicznych autobusów stworzył koncern technologiczny Huawei. W Szkocji część autostrady E8 koło Edynburga ma być przeznaczona dla autonomicznych autobusów - będą kursować specjalnie wydzielonym pasem, niedostępnym dla innych pojazdów. Podobnie jak autobusy w Maladze, szkockie pojazdy mają mieć na pokładzie kierowców (Fleming, 2021).

Pojazdy autonomiczne mają potencjał szerszego wykorzystania w rzeczywistych warunkach transportu publicznego. Dotychczasowe doświadczenia to jednak raczej kursy pojedynczych pojazdów, nadzorowanych przez człowieka, często w specyficznych warunkach - częściowego lub całkowitego odseparowania od ruchu drogowego. Jako mocne strony przemawiające za możliwością wprowadzenia autonomicznych pojazdów do ruchu wskazuje się między innymi bezpieczeństwo automatyzacja ruchu pozwoliłaby na zniwelowanie skutków zdarzeń drogowych, gdyż pojazdy tego typu będą miały więcej rozwiązań technicznych podnoszących poziom bezpieczeństwa. Mówi się także o zwiększeniu mobilności osób niepełnosprawnych - chodzi o nowe możliwości i wyższy komfort ich przemieszczania. Redukcja kosztów kongestii to kolejna ważna zaleta. Jako słabe strony wskazuje się między innymi trudności komunikacyjne zaawansowanych technicznie pojazdów, konieczność „zaufania“ technologii i urządzeniom oraz kwestie odpowiedzialności prawnej (Neumann, 2018).

$\mathrm{Na}$ świecie są już z powodzeniem wykorzystywane systemy transportu szynowego działające w sposób autonomiczny. O ile jednak zautomatyzowanie ruchu na wydzielonym torowisku pojazdu szynowego jest w zasięgu współczesnych możliwości technicznych, o tyle wyzwaniem pozostaje zautomatyzowanie „klasycznego” ruchu tramwajowego. Poniżej wskazano dwa przykłady miast i prac związanych $\mathrm{z}$ automatyzacją ruchu tramwajowego.

Kilka lat temu Siemens Mobility stworzył asystenta jazdy tramwajowej - Siemens Tram Assistant, którego zadaniem jest wspieranie motorniczych, między innymi ostrzeganie przed kolizją. Rozwiązanie to wdrożono w tramwajach w Hadze (Holandia) i Ulm (Niemcy), już wkrótce ma ono być także wprowadzone w tramwajach w Bremie (Niemcy) i Kopenhadze (Dania). Następnym etapem było zaprezentowanie w trakcie jazd testowych pierwszego autonomicznego tramwaju - w 2018 roku, we współpracy z przewoźnikiem z Poczdamu (Niemcy). Pojazd jest gotowy do kolejnych etapów - „uczenia się” sposobu funkcjonowania sygnalizacji świetlnych i współpracy z infrastrukturą. Wykorzystując wiele lat doświadczenia w zakresu automatyki, analizę danych i sztuczną inteligencję, firma nadal optymalizuje sposób poruszania się pojazdu (Siemens.com, 2021). 


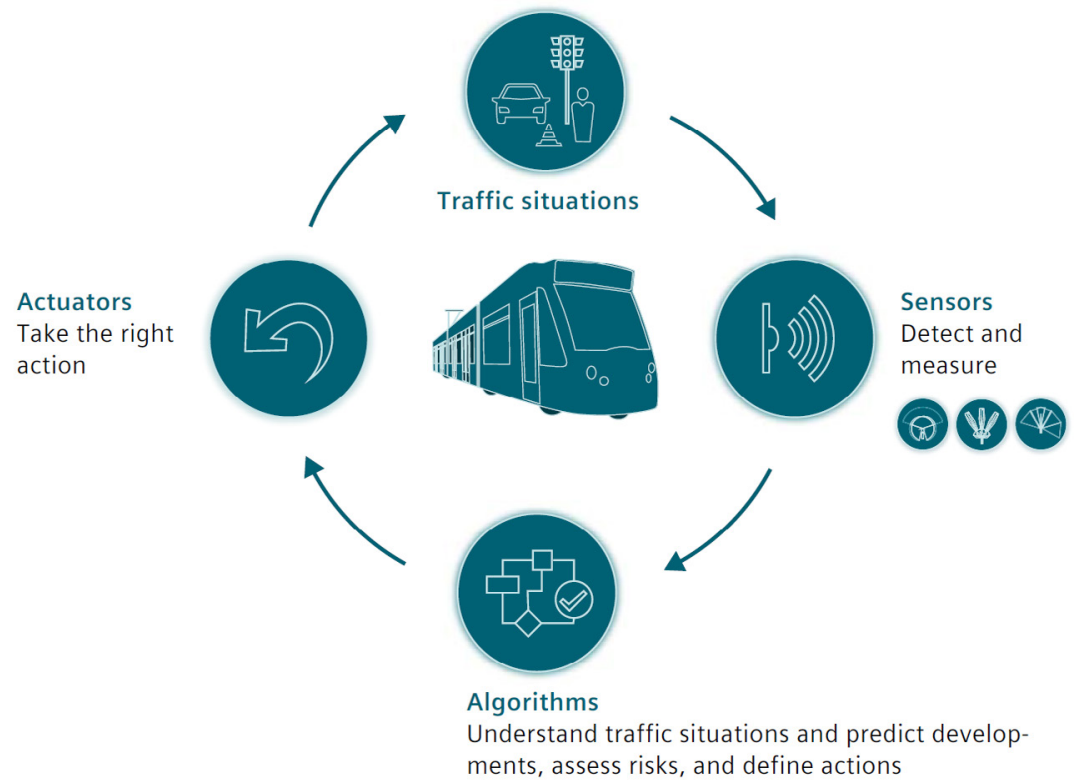

\section{Rysunek 4.5. Zasada działania tramwaju autonomicznego}

Źródło: (Siemens.com, 2021).

Na rysunku 4.5 przedstawiono zasadę działania autonomicznego tramwaju Siemens. Pojazd korzysta ze sprawdzonych technologii - w autonomicznych samochodach, autobusach czy ciężarówkach obowiązują podobne założenia techniczne. Pojazd korzysta z radarów, lidarów i czujników jako cyfrowych „oczu”. Następnie kompleksowo analizujące dane algorytmy przetwarzają te informacje, aby „mózg” systemu mógł zinterpretować sygnały, ocenić specyficzną sytuację na drodze i podjąć odpowiednią decyzję dotyczącą ruchu pojazdu. Kolejny etap to "przewidywanie” chociażby w zakresie aktualnej sytuacji ruchowej - i reagowanie na sytuacje, które mogą się wydarzyć (Siemens.com, 2021).

Podstawowym celem projektu „Autonomizacja jazdy tramwajem jako narzędzia wspierającego pracę motorniczych“ jest wdrożenie tzw. „asystenta prowadzącego“, który pozwoli wspomóc pracę motorniczego i nadzorować parametry jazdy tramwaju - przede wszystkim ze względów bezpieczeństwa. Chodzi w szczególności o zwalnianie tramwaju, gdy motorniczy rozpędzi się do zbyt dużej prędkości, hamowanie przystankowe czy generalnie - dostosowanie prędkości do warunków na drodze. A docelowo - na przykład o dostosowanie prędkości tramwaju do układu sygnalizacji świetlnej, aby przejazd był jak najbardziej płynny. Prace te zaowocowały pierwszym w Polsce przejazdem tramwaju bez motorniczego - w nocy z 27 na 28 stycznia 2020 roku w Krakowie. Projekt badawczo-rozwojowy jest realizowany $\mathrm{z}$ wykorzystaniem tramwaju typu $126 \mathrm{~N}$ wyprodukowanego przez Newag 
S.A. Układ sterowania autonomicznego komunikuje się z głównym sterownikiem tramwaju - steruje prędkością, drzwiami, dzwonkiem oraz sygnałami z pokładu pojazdu - chociażby przyciskami awaryjnymi, na przykład hamulcem bezpieczeństwa. System, na podstawie wskazań z nawigacji satelitarnej oraz pomiaru drogi, pozwala na automatyczne zatrzymywanie na przystankach, otwieranie i zamykanie drzwi, ruszanie z przystanku. Pojazd reaguje na ograniczenia prędkości czy specyficzne elementy infrastruktury - na przykład izolatory sekcyjne (Krakow.pl, 2020).

\subsection{Napędy alternatywne dla pojazdów komunikacji publicznej}

Temat alternatywnych napędów w zasilaniu pojazdów jest tematem stosunkowo często poruszanym zarówno w publikacjach naukowych, i jak i popularno-naukowych. Znacznie rzadziej pojawia się on w kontekście pojazdów komunikacji publicznej, a jeszcze rzadziej w kontekście zarządzania transportem publicznym i nauk o zarządzaniu. Dzieje się tak z kilku powodów. Po pierwsze - wśród pojazdów poruszających się w przestrzeni publicznej pojazdy komunikacji publicznej stanowią mniejszość. Po drugie - jeżeli nawet są one przedmiotem zainteresowania badaczy, to zwykle w kontekście stosowanych rozwiązań technicznych. Budzą zatem zainteresowanie bardziej nauk technicznych niż nauk o zarządzaniu.

Zwykle pod hasłem alternatywnych źródeł energii mówi się o źródłach odnawialnych, stanowiących alternatywę dla paliw kopalnych, czyli o energii słonecznej, geotermalnej, energii wody lub wiatru. Można się też spotkać z definicjami, które odnoszą się nie tylko do źródeł odnawialnych, ale także do innych niż zwykle wykorzystywane źródeł nieodnawialnych

Ustawa o elektromobilności i paliwach alternatywnych definiuje paliwa alternatywne jako „paliwa lub energię elektryczną wykorzystywane do napędu silników pojazdów samochodowych lub jednostek pływających stanowiące substytut dla paliw pochodzących z ropy naftowej lub otrzymywanych w procesach jej przetwórstwa, w szczególności energię elektryczną, wodór, biopaliwa ciekłe, paliwa syntetyczne i parafinowe, sprężony gaz ziemny (CNG), w tym pochodzący z biometanu, skroplony gaz ziemny (LNG), w tym pochodzący z biometanu, lub gaz płynny (LPG)“ (Ustawa, 2018, s. 3).

Na podstawie powyższej definicji można zidentyfikować pewien sztywny zbiór napędów alternatywnych wykorzystywanych w przypadków pojazdów komunikacji publicznej. Należy zauważyć, że systematyka ta znajduje dziś odniesienie przede wszystkim do trakcji autobusowej (i pochodnych). W przypadku transportu szyno- 
wego mamy zwykle do czynienia $\mathrm{z}$ jednym $\mathrm{z}$ dwóch podstawowych źródeł napędu (silnik diesla / napęd elektryczny), a rozwiązania alternatywne są niezwykle rzadkie. Jednak aby przedstawić możliwie pełny obraz dostępnych rozwiązań technicznych, w dalszej części podrozdziału przedstawiono także i takie przykłady.

Temat napędów alternatywnych w transporcie nie jest tematem nowym. W 2013 roku została opublikowana „Strategia Rozwoju Transportu do 2020 roku (z perspektywą do 2030 roku)”. „Strategia Rozwoju Transportu (SRT) jest średniookresowym dokumentem planistycznym, który zgodnie z ustawą $\mathrm{z}$ dnia 6 grudnia 2006 roku o zasadach prowadzenia polityki rozwoju (Dz. U. z 2009 r. Nr 84, poz. 712 i Nr 157, poz. 1241 oraz z 2011 roku Nr 279, poz. 1644), zwanej dalej »ustawą o zasadach prowadzenia polityki rozwoju «i uchwałą Rady Ministrów, z dnia 24 listopada 2009 roku w sprawie planu uporządkowania strategii rozwoju stanowi integralny element spójnego systemu zarządzania krajowymi dokumentami strategicznymi. Istotą SRT jest wskazanie celów oraz nakreślenie kierunków rozwoju transportu tak, aby etapowo do 2030 roku możliwe było osiągnięcie celów założonych w Długookresowej Strategii Rozwoju Kraju (DSRK) oraz Średniookresowej Strategii Rozwoju Kraju (SRK 2020)" (Ministerstwo Infrastruktury, 2013, s. 5). Konieczność tworzenia „Zrównoważonego" systemu transportowego wskazano już w celu głównym tego dokumentu, a „ograniczanie negatywnego wpływu transportu na środowisko” jako jeden z celów szczegółowych. Z kolei w ujęciu gałęziowym (sektorowym) wskazano sześć obszarów oddziaływania strategii, a jako jeden $\mathrm{z}$ nich - transport miejski (Ministerstwo Infrastruktury, 2013). W rozdziale 7 omawianego dokumentu przedstawiono działania i kierunki działań w zakresie ograniczania wpływu transportu na środowisko. Jako wyzwania potraktowano tu zarówno politykę unijną, jak i zmiany klimatyczne czy wzrost cen paliw kopalnych.

W „Strategii Rozwoju Transportu” (Ministerstwo Infrastruktury, 2013, s. 80) wskazano, że należy wspierać rozwój transportu w zakresie:

- „różnorodności gałęziowej i komplementarności środków transportu w obrębie systemu połączeń krajowych i międzynarodowych;

- rozwiązań organizacji transportu najmniej zanieczyszczających środowisko;

- zarządzania popytem na ruch transportowy;

- wdrażania nowoczesnych technologii transportowych redukujących negatywne oddziaływanie transportu na środowisko".

Zapisy wskazane w dokumencie na pierwszy rzut oka wydają się dosyć ogólne, są jednak rozpisane bardziej szczegółowo pod postacią trzech „kierunków interwencji”, które mogą być realizowane w celu obniżenia wpływu transportu na środowisko, tj. kierunków o charakterze organizacyjno-systemowym, inwestycyjnym i innowacyjno-technicznym.

Krokiem na drodze do zrównoważonej mobilności miała być ustawa $\mathrm{z}$ dnia 11 stycznia 2018 roku o elektromobilności i paliwach alternatywnych. Jej pojawienie 
się miało na celu przede wszystkim określenie zasad rozwoju i funkcjonowania infrastruktury dla paliw alternatywnych czy warunków funkcjonowania stref czystego transportu (Ustawa, 2018).

W świetle tej ustawy należy zwrócić uwagę na niezwykle ważny zapis znajdujący się w artykule 36: „1. Jednostka samorządu terytorialnego, z wyłączeniem gmin i powiatów, których liczba mieszkańców nie przekracza 50 000, świadczy usługę lub zleca świadczenie usługi komunikacji miejskiej w rozumieniu ustawy z dnia 16 grudnia 2010 roku o publicznym transporcie zbiorowym (Dz.U. z 2019 r. poz. 2475 i 2493 oraz z 2020 r. poz. 400 i 462) podmiotowi, którego udział autobusów zeroemisyjnych we flocie użytkowanych pojazdów na obszarze tej jednostki samorządu terytorialnego wynosi co najmniej 30\%" (Ustawa, 2018, s. 23). Przepis ten (w odniesieniu do 30\% pojazdów) wchodzi co prawda w życie dopiero od 1 stycznia 2028 roku, niemniej jednak zgodnie $\mathrm{z}$ art. 68. ust. 4 zobowiązano jednostki samorządu terytorialnego do osiągania wskaźników pośrednich - 5\% od 1 stycznia 2021 roku, $10 \%$ od 1 stycznia 2023 roku i 15\% od 1 stycznia 2025 roku (Ustawa, 2018).

Należy zwrócić uwagę także na definicję samego autobusu zeroemisyjnego. Według ustawy o elektromobilności i paliwach alternatywnych (art. 2, ust. 1) autobus zeroemisyjny to ,autobus $\mathrm{w}$ rozumieniu art. 2 pkt 41 ustawy $\mathrm{z}$ dnia 20 czerwca 1997 r. - Prawo o ruchu drogowym (Dz.U. z 2020 r. poz. 110, 284, 568 i 695), wykorzystujący do napędu energię elektryczną wytworzoną z wodoru w zainstalowanych w nim ogniwach paliwowych lub wyłącznie silnik, którego cykl pracy nie prowadzi do emisji gazów cieplarnianych lub innych substancji objętych systemem zarządzania emisjami gazów cieplarnianych, o którym mowa w ustawie z dnia 17 lipca 2009 roku o systemie zarządzania emisjami gazów cieplarnianych i innych substancji (Dz.U. z 2019 r. poz. 1447 i 1501 oraz z 2020 r. poz. 284) oraz trolejbus w rozumieniu art. 2 pkt 83 ustawy z dnia 20 czerwca 1997 r. - Prawo o ruchu drogowym" (Ustawa, 2018, s. 1). Należy zatem zauważyć, że zgodnie z tą definicją samorządy (chcąc zapewnić realizację celu postawionego $\mathrm{w}$ ustawie) powinny inwestować $\mathrm{w}$ autobusy elektryczne lub wodorowe, ale już niekoniecznie w autobusy hybrydowe czy zasilane gazem ziemnym (CNG, LNG), gdyż te pojazdy w związku z emitowaniem gazów cieplarnianych nie spełniają definicji autobusu zeroemisyjnego. `Oczywiście pojazdem zeroemisyjnym pozostaje także trolejbus.

W 2017 roku w Polsce (na szczeblu Ministerstwa Energii) przyjęto dokument „Krajowe ramy polityki rozwoju infrastruktury paliw alternatywnych* ${ }^{\star} \mathrm{W}$ świetle tego dokumentu „paliwa alternatywne (w rozumieniu dyrektywy 2014/94/UE) oznaczają paliwa lub źródła energii, które służą przynajmniej częściowo jako substytut dla pochodzących z surowej ropy naftowej źródeł energii w transporcie i które mogą potencjalnie przyczynić się do wzrostu neutralności klimatycznej transportu

* Z uwagi na złożoność problematyki w publikacji nie analizowano dokumentów wyznaczających politykę transportową w szerszym kontekście, zarówno unijnym, jak i krajowym, w szczególności regulacji europejskich zapisów tzw. Białej Księgi Transportu itp. 
i poprawy ekologiczności sektora transportu, są to między innymi: energia elektryczna, wodór, biopaliwa, paliwa syntetyczne i parafinowe, gaz ziemny CNG lub LNG, gaz płynny (LPG)” (Krajowe Ramy..., 2017, s. 4).

Zarówno unijne, jak i krajowe regulacje prawne nakazują, aby miasta inwestowały w alternatywne źródła energii. Tendencja ograniczania emisji zanieczyszczeń także w przypadku klasycznych silników spalinowych była już widoczna od wielu lat - chociażby w kolejnych normach emisji spalin (od Euro 0 do Euro 6).

$\mathrm{Z}$ danych Europejskiej Agencji Środowiskowej wynika, że branża transportowa (w tym transport miejski) odpowiadała w 2015 roku za ponad 25\% emisji gazów cieplarnianych na terenie Unii Europejskiej, a sam transport miejski - za emisję $25 \%$ dwutlenku węgla w transporcie ogółem (Gis, 2018). W 2020 roku sprzedano w Polsce 704 autobusy miejskie o czterech rodzajach napędu (rysunek 4.6).

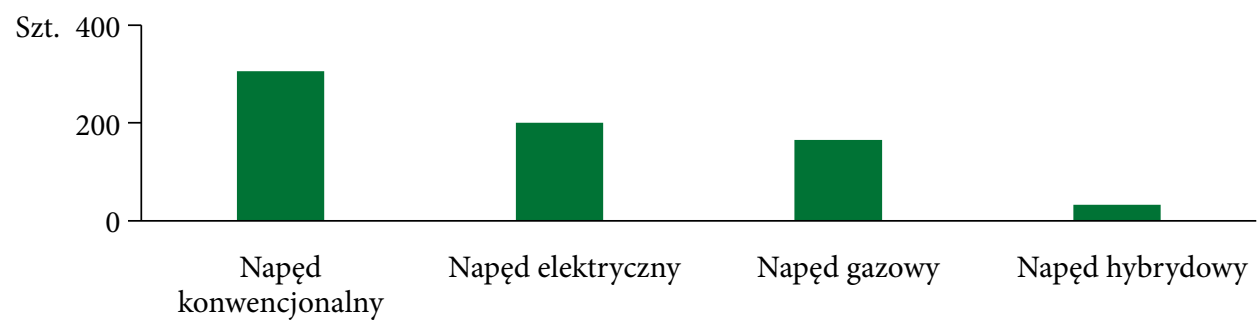

Rysunek 4.6. Sprzedaż autobusów miejskich na rynku polskim, z podziałem na źródła napędu

Źródło: (pire.pl, 2021).

Udział pojazdów zeroemisyjnych i niskoemisyjnych w strukturze taboru autobusowego w 2019 roku kształtował się jak przedstawiono na rysunku 4.7.

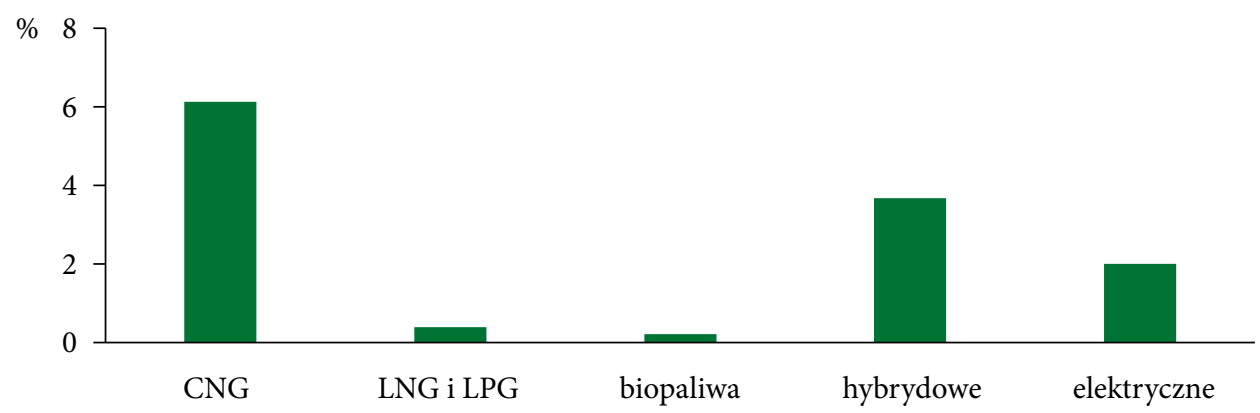

Rysunek 4.7. Udział pojazdów zeroemisyjnych i niskoemisyjnych w strukturze taboru autobusowego $\mathrm{w} 2019$ roku

Źródło: (Izba Gospodarcza Komunikacji Miejskiej, 2021). 
Wymogi prawne oraz oczekiwania o charakterze społecznym sprawiają, że transport miejski stoi przed wyzwaniem całkowitej redukcji spalin. Z uwagi na kwestie kosztowe czy przestrzenne nie wszędzie jest możliwe zastąpienie autobusów pojazdami szynowymi - zatem w tych obszarach komunikacja autobusowa będzie stanowiła podstawowy środek transportu (Ziembicki i Pyza, 2018). Między innymi właśnie dlatego napędy alternatywne są domeną trakcji autobusowej. Nie da się wyeliminować autobusu z miejskiej przestrzeni i systemu transportowego miasta, stąd tak wiele prób i pomysłów na ciągłe jego, także pod względem środowiskowym.

\section{CNG (gaz ziemny sprężony)}

Pierwsze próby zasilania autobusów gazem ziemnym pojawiły się w latach 70 . XX wieku. W Polsce, w latach 80., powstał prototyp dwupaliwowego Jelcza PR110 (zasilanie ropą naftową i gazem ziemnym), a pierwsze wdrożenia pojazdów zasilanych CNG na szerszą skalę odbyły się w latach 90 . Gaz ziemny jest nietoksyczny, bezwonny, lżejszy od powietrza, ale także jest gazem małej gęstości i wymaga składowania w pojemnych, ciężkich butlach pod wysokim ciśnieniem (cng.auto.pl, 2021a).

$\mathrm{Z}$ uwagi na spalanie innego rodzaju paliwa autobusy zasilane CNG zwykle cechują się cichszą pracą silnika, mniejszym zadymieniem spalin. Paliwo zasilające może być wytwarzane także z biomasy lub odpadów komunalnych (tzw. biogaz), choć w Polsce nie wdrożono jeszcze takich rozwiązań. Minusem zasilania CNG jest konieczność budowy infrastruktury tankowania - stacje tego typu nie są powszechne, a koszt budowy takiego obiektu szacuje się na około 1,5-2 mln zł (cng.auto.pl, 2021a). Tego typu obiekty były lokalizowane między innymi u przewoźników autobusowych, którzy decydowali się na wykorzystanie autobusów zasilanych CNG.

PGNiG nazywa gaz ziemny paliwem przyszłości i traktuje go jako uniwersalną, ekologiczną i niskoemisyjną alternatywę zarówno dla benzyny, jak i oleju napędowego. Ponieważ głównym składnikiem CNG jest metan, jest to nie tylko paliwo wydajniejsze i tańsze, ale także bardziej przyjazne dla środowiska, między innymi poprzez niższą emisję pyłków i tlenków azotu (Polskie Górnictwo Naftowe i Gazownictwo, 2021). PGNiG obsługuje obecnie 17 stacji CNG na terenie kraju. Są one zlokalizowane w Tarnowie, Rzeszowie, Wrocławiu, Tychach, Zamościu, Toruniu, Poznaniu, Gdyni, Trzebini, Świdniku (Lublinie), Sandomierzu, Mielcu, Kobylnicy (Słupsku), Krakowie, Warszawie, Radomiu i Wałbrzychu (Polskie Górnictwo Naftowe i Gazownictwo, 2021). Większość takich stacji znajduje się w południowo-wschodniej części kraju. I tam też przez ostatnie kilkanaście lat eksploatowano zdecydowaną większość autobusów zasilanych CNG.

W 2020 roku sprzedaż gazu ziemnego CNG na stacjach zarządzanych przez PGNiG Obrót Detaliczny wzrosła o 31\%. To efekt przede wszystkim zmian w transporcie publicznym - tylko w 2020 roku polskie miasta zakupiły 165 autobusów 
zasilanych CNG, a flota tego typu pojazdów na terenie całego kraju wynosi obecnie około 800 sztuk pojazdów. Prawie co drugi sprzedawany w Polsce autobus na tzw. paliwa alternatywne był autobusem CNG, a w ostatnich latach tego typu nowe pojazdy pojawiły się między innymi w Warszawie, Rzeszowie, Tarnowie, Tychach i Bielsku-Białej (Transport-publiczny.pl, 2021).

„Za stosowaniem CNG jako paliwa przemawiają czynniki ekonomiczne, środowiskowe oraz dywersyfikacja paliw" (Owczarzak, 2016, s. 656). Aby zwiększać konkurencyjność tego napędu, należy pamiętać o kilku zasadach: tabor powinien być nowy $\mathrm{z}$ fabryczną instalacją, a infrastruktura tankowania odpowiednio zaplanowana (uwzględniająca specyfikę działania przedsiębiorstwa oraz eksploatowaną flotę zarówno CNG, jak i z wykorzystaniem innych paliw). Oszczędności na paliwie mogą sięgać 36\%, a eksploatacja dwóch autobusów zasilanych CNG przy dystansie 200 tys. $\mathrm{km}$ rocznie daje zmniejszenie emisji substancji szkodliwych o 32,8 ton (Owczarzak, 2016).

\section{LNG (gaz ziemny płynny)}

Wprowadzanie do ruchu autobusów zasilanych gazem ziemnym w wersji skroplonej wciąż uchodzi za dużą ciekawostkę. Pierwsze duże projekty tego typu pojawiły się w Polsce kilka lat temu.

W grudniu 2013 roku przedstawiciele Miejskich Zakładów Autobusowych w Warszawie podpisali umowę na zakup 35 autobusów zasilanych skroplonym gazem ziemnym. Zgodnie z umową pojazdy Solbus SM LNG w wersji 18-metrowej miały trafić do ruchu w 2015 roku. Zwycięskie konsorcjum (Lider Trading i Gazprom Germania) miało zapewnić także dostawę paliw przez okres 10 lat (cng. auto.pl, 2021b). Rok 2015 był czasem krótkiego boomu na autobusy LNG - obok opisywanego projektu w Warszawie takie autobusy pojawiły się także w Olsztynie. Łącznie było ich 45 sztuk, co stanowi do dziś największą flotę pojazdów tego typu w Europie i jedną z większych na świecie (Transinfo.pl, 2020).

Ostatnie lata upływają pod znakiem kolejnych zamówień na autobusy zasilane LNG. W 2020 roku Miejskie Zakłady Autobusowe rozstrzygnęły przetarg na 160 autobusów zasilanych CNG i LNG, a wśród nich - 90 autobusów przegubowych zasilanych gazem w wersji płynnej. Tym samym do Warszawy trafiają kolejne autobusy z takim napędem, na przykład Autosan Sancity budowany na licencji marki Solbus model SM18LNG (Urbanowicz, 2020). Jednocześnie w 2019 roku podpisano w MZA nową umowę na dostawy paliwa gazowego do eksploatowanych już wcześniej 35 autobusów. Wcześniejszy dostawca paliwa zbankrutował, przewoźnik był zatem zmuszony do zorganizowania tankowania pojazdów we własnym zakresie. Przewoźnik posiada obecnie we flocie zarówno autobusy zasilane LNG, jak i CNG. W obu przypadkach paliwem jest tu gaz ziemny, choć w różnym stanie skupienia. W autobusach zasilanych LNG zbiornik paliwa znajduje się z tyłu pojazdu - jest 
mniejszy niż w autobusach CNG, a samo tankowanie trwa krócej - kilka, a nie kilkanaście minut jak w CNG. Przedstawiciele MZA przyznają, że pomimo upadku producenta autobusy sprawdzają się bardzo dobrze (Dybalski, 2019). Na rysunku 4.8 przedstawiono warszawski autobus miejski zasilany gazem skroplonym.

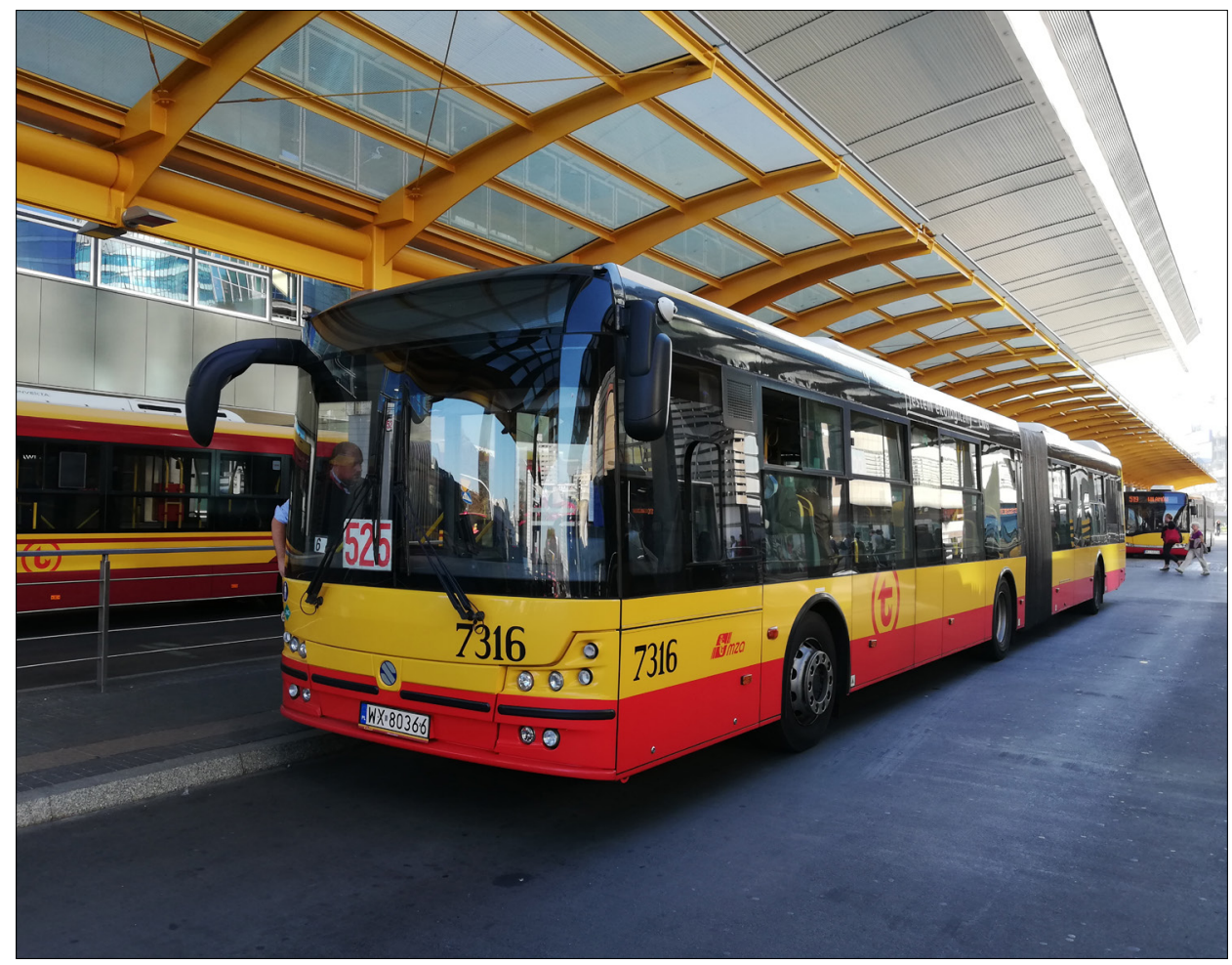

Rysunek 4.8. Autobus miejski w Warszawie, zasilany gazem LNG

Choć autobusy zasilane LNG poruszają się po polskich drogach już od kilku lat, w 2019 roku koncern Scania poinformował, że do włoskiego miasta Bolonia dostarczono „pierwszy autobus LNG w Europie”, co miało wyznaczyć nowy kierunek w rozwoju komunikacji międzymiastowej. W odpowiedzi na pierwsze publiczne zamówienie na autobusy zasilane LNG Scania dostarczyła 15 takich pojazdów. Operator TPER jest znany między innymi z obsługi sieci trolejbusowej (we flocie ma ponad 100 pojazdów elektrycznych, w większości właśnie trolejbusów), największej we Włoszech sieci autobusów hybrydowych i łącznie 311 pojazdów zasilanych gazem CNG. Firma chwali się, że dzięki inwestycji w nowoczesne napędy ograniczyła emisję gazów cieplarnianych o $20 \%$ w ostatnich trzech latach. Nowa Scania ma zapewniać połączenie - korzyści środowiskowych związanych z zasilaniem pojazdów gazem ziemnym (które to korzyści są potwierdzone wieloma latami doświadczeń), 
z korzyściami ze zwiększonego zasięgu (co jest efektem zastosowania technologii LNG). Nowe pojazdy zakupiono z myślą o obsłudze podmiejskich linii autobusowych w Bolonii oraz zastąpieniu kursujących na nich pojazdach z silnikami diesla (Sustainable-bus.com, 2019).

\section{LPG}

Jednym z ciekawych paliw alternatywnych w napędach pojazdów komunikacji publicznej pozostaje LPG. W Polsce napęd ten był niezwykle popularny w samochodach osobowych, a w autobusach jest w naszym kraju praktycznie niespotykany. O tym, że może to być efektywne narzędzie budowania floty pojazdów zasilanych paliwem alternatywnym, świadczy chociażby przykład Wiednia.

Przewoźnik Wiener Linien obsługuje komunikację miejską na terenie stolicy Austrii i od wielu lat eksploatuje pojazdy zasilane LPG. Pierwsze próby z tym napędem podjęto w latach 60. XX wieku - początkowo wprowadzając do ruchu pojazdy z zasilaniem mieszanym (dwupaliwowe: w 70\% olej napędowy, w 30\% LPG). Obecnie wszystkie pojazdy przewoźnika (blisko 500 sztuk) są napędzane silnikami spalinowymi o zapłonie iskrowym, zasilanymi autogazem. Dominują pojazdy MAN i austriackiej marki Gräf \& Steyr. W stosunku do tradycyjnych silników diesla silniki zasilane LPG są dużo bardziej przyjazne środowisku. LPG spala się praktycznie bez emisji cząstek stałych, a zastosowanie trójdrożnych katalizatorów w układzie wylotowym pozwala również zmniejszyć emisję tlenków azotu. Kolejnym etapem rozwoju ma być wprowadzenie autobusów elektrycznych, które będą systematycznie zastępować autobusy gazowe (Złoty, 2011).

Jako przykład zastosowania autobusów zasilanych LPG na polskim rynku może posłużyć Miejska Komunikacja Samochodowa w Dębicy. Kłopoty z wyeliminowaniem $\mathrm{w}$ tradycyjnych autobusach diesla problemu dymienia doprowadziły do przebudowania pierwszych pojazdów na zasilanie LPG. Zdecydowano na adaptację pojazdów już posiadanych przez MKS Mielec - Jelcz PR110 i Autosan H9-35, wykonując modernizację silników oraz dostosowując konstrukcję (kratownicę) do zabudowy zbiorników gazowych. Adaptację pojazdów wykonała firma NGV Autogas z Krakowa. W szczytowym momencie w Dębicy eksploatowano 25 autobusów zasilanych LPG, a z uwagi na zużycie eksploatacyjne były one stopniowo wycofywane z eksploatacji - ostatni został skasowany w 2011 roku (Złoty, 2011). W MKS Dębica wprowadzenie autobusów gazowych było związane z ich modernizacją i remontami kapitalnymi. Środki na ten cel wyasygnował między innymi Wojewódzki Fundusz Ochrony Środowiska w Tarnowie - udzielając częściowo umorzonej pożyczki. Autobusy badano między innymi pod kątem późniejszej emisji spalin i hałasu - udało się nie tylko spełnić założone limity, ale jeszcze je obniżyć (Rudkowski i Dybaś, 2000).

W 2016 roku, dokładnie 22 września, a zatem w Europejskim Dniu bez Samochodu, na ulice hiszpańskiego miasta Valladolid wyjechał autobus miejski napę- 
dzany gazem LPG - woził pasażerów za darmo, w ramach promowania komunikacji publicznej. Był to kolejny taki test autobusu zasilanego tym właśnie paliwem w taborze Auvasa - lokalnego przewoźnika autobusowego. Zastąpienie autobusów dieslowskich autobusami gazowymi argumentowano między innymi czystszym powietrzem. Zdecydowano się na wdrażanie LPG, a nie zwykle używanego gazu ziemnego (CNG/LNG) (Markowski, 2017). Kilka lat później wyraźnie widać, jaką drogą podążał przewoźnik Auvasa, poszukując odpowiedniego źródła napędu do swoich pojazdów. Obecnie operator ten dysponuje flotą 150 pojazdów, z których zaledwie co trzeci posiada klasyczny napęd spalinowy. Dominują autobusy zasilane gazem LPG (75 sztuk), w taborze są także autobusy hybrydowe (18 sztuk), a w 2020 roku dołączyło do nich 7 pojazdów zasilanych gazem CNG (Aubasa, 2021).

\section{Napędy hybrydowe}

Autobusy hybrydowe przez lata postrzegano jako „krok” w stronę autobusu w pełni elektrycznego. Za pierwszy w Europie autobus hybrydowy zwykle uznaje się polską konstrukcję Solarisa Urbino Hybrid, zaprezentowaną w 2006 roku. Pierwszy tego typu pojazd wyjechał na polskie drogi w 2008 r. - jego eksploatację rozpoczęło Miejskie Przedsiębiorstwo Komunikacyjne w Poznaniu. Był to ósmy tego typu autobus na drogach Europy, wcześniej solarisy z napędem hybrydowym zakupiły miasta: Drezno, Lipsk, Bochum i Lenzburg, a także Brema, Monachium i Hanower (Karaczun, 2008). Powszechnie uważano (i dalej tak jest), że autobus hybrydowy pozwoli na wyraźne zmniejszenie zużycia paliwa w przypadku autobusów miejskich. $\mathrm{Z}$ uwagi na specyfikę ruchu praca w autobusach (podobnie jak i innych pojazdach komunalnych) polega na ciągłym rozruchu i licznych zatrzymaniach - co daje potencjał do odzyskiwania energii i ponownego jej wykorzystywania. Z czasem konstrukcje autobusów hybrydowych trafiły do oferty wszystkich głównych procentów autobusów na rynku europejskim, a doświadczenia $\mathrm{z}$ ich eksploatacji były niezwykle cenne przy budowie pojazdów w pełni elektrycznych.

Już kilka lat temu zauważono, że „klasyczny” podział pomiędzy autobusem spalinowym a pojazdem elektrycznym (trolejbusem) zaczyna się zacierać. Dotychczas głównym wyznacznikiem rozróżnienia była bowiem obecność napędu spalinowego. W pojeździe hybrydowym podstawowym źródłem napędu jest klasyczny silnik spalinowy, a jego uzupełnieniem - silnik elektryczny. W pojazdach tego typu silnik elektryczny nie daje możliwości samodzielnego eksploatowania autobusu w ruchu liniowym, a jedynie wsparcie podstawowego napędu. Celem zastosowania silnika elektrycznego (który może pracować równolegle ze spalinowym lub samodzielnie przy niskich prędkościach, na przykład przy ruszaniu z przystanków) jest zmniejszenie hałasu i emisji zanieczyszczeń (Molecki, 2017).

Należy zauważyć, że choć powszechnie uznaje się, iż to Solaris zapoczątkował erę autobusów hybrydowych, to prace nad pojazdami z takim napędem trwają od 
wielu lat. Na przykład koncern Daimler (producent autobusów Mercedes) zaprezentował pierwszy pojazd tego typu już w 1969 roku, a kolejne jego modele wdrażano także do eksploatacji: chociażby w stolicy Ekwadoru - Quito (200 pojazdów) czy Stuttgarcie i Esslingen (50 pojazdów). W latach 1999-2003 produkowano także minibus Mercedes Cito z aluminiowym nadwoziem i napędem spalinowo-elektrycznym (Rusak, 2008a).

Pierwsze autobusy hybrydowe Solaris trafiły do miast niemieckich i eksploatacji w DVB Drezno, LVG Lipsk i BOGESTRA Bochum, a jeden $z$ autobusów - do prywatnego przewoźnika Eurobus i obsługi szwajcarskiego miasta Lenzburg. Z pomiarów wynikało, że autobus hybrydowy Solaris Urbino 18 Hybrid pierwszej generacji zapewniał o $15 \%$ mniejsze zużycie paliwa, zmniejszoną emisję zanieczyszczeń (tlenków azotu o 39\% i cząstek stałych o 97\%), niższą emisję hałasu, zwiększoną żywotność okładzin i tarcz hamulcowych oraz dwa razy rzadszą wymianę oleju (Rusak, 2008b).

\section{Autobus elektryczny}

Prototyp autobusu bateryjnego firmy Solaris zaprezentowano w 2011 roku. Nikt wówczas nie przypuszczał, że po kilku latach polski producent będzie liderem rynku autobusów elektrycznych i jednym z wytyczających trendy w sektorze nowych napędów do pojazdów komunikacji publicznej. Powstanie i tak duży sukces autobusu elektrycznego były możliwe między innymi dzięki doświadczeniom, jakie producent już wcześniej nabył podczas produkcji trolejbusów. Ekspansja polskiego producenta dała także impuls do rozwoju dostawców komponentów istotnych w pojazdach elektrycznych - firm Medcom czy EkoEnergetyka (Rusak, 2018)

Obecnie obserwujemy gwałtowny rozwój zarówno polskiego, jak i europejskiego rynku autobusów elektrycznych. Ostatnie kilka lat należy uznać za rewolucję w krótkim czasie pojazdy tego typu na stałe wpisały się w krajobraz europejskich miast. A niemały jest w tym udział wspomnianej firmy Solaris. Autobusy elektryczne potoczenie są dziś często nazywane po prostu „elektrobusami”.

W 2014 roku na rynku zadebiutował pierwszy seryjny autobus elektryczny wyprodukowany przez firmę Solaris. Solaris Urbino 12 Electric uzyskał także prestiżowy tytuł Bus of the Year 2017. Dziś firma Solaris (od 2018 roku całość udziałów w Solarisie posiada hiszpańska grupa CAF) jest największym europejskim producentem autobusów elektrycznych (Businessinsider.com.pl, 2020).

W 2020 roku zarejestrowano w Polsce 200 sztuk nowych tego typu pojazdów co stanowiło $28,5 \%$ ogólnej sprzedaży wszystkich autobusów miejskich w kraju. Obecnie po polskich drogach porusza się 468 autobusów elektrycznych. Po czterech miesiącach 2021 roku najwięcej autobusów elektrycznych porusza się po Warszawie (162 szt.), Krakowie (59 szt.), Jaworznie (44 szt.) i Zielonej Górze (43 szt.). Zdecydowaną większość z nich (375 szt.) stanowią autobusy marki Solaris, 
drugim dostawcą jest Ursus (68 szt.). Samorządy z jednej strony kupują autobusy elektryczne, aby realizować założenia ustawy o elektromobilności i paliwach alternatywnych, $\mathrm{z}$ drugiej - widzą $\mathrm{w}$ transporcie elektrycznym także korzyści natury ekonomicznej (pire.pl, 2021).

Podobnie jak w przypadku każdego innego rodzaju napędu alternatywnego początkowe zakupy operatorów ograniczały się do pojedynczych sztuk taboru. Ryzykiem, którego bali się przewoźnicy, były między innymi parametry techniczne takiego pojazdu. W szczególności dotyczyło to deklarowanego przez producentów zasięgu. Pojazdy elektryczne cechuje bowiem pewna specyfika. Aby zapewnić większy zasięg, konieczne jest wyposażenie pojazdu w baterie o większej pojemności. To $\mathrm{z}$ kolei zwiększało masę pojazdów, a w konsekwencji zużycie energii $\mathrm{w}$ przeliczeniu na każdy przejechany kilometr... i zmniejszało zasięg. Niezbędne było zatem odpowiednie oszacowanie zapotrzebowania na moc i dostarczenie autobusów z maksymalnym, ale rozsądnym wagowo układem bateryjnym. Drugim problemem pozostawało oszacowanie zasięgu w zmiennym ruchu miejskim. W praktyce nie jest możliwe precyzyjne określenie zapotrzebowania na energię, które zależy od godzin szczytu, specyfiki dnia czy warunków pogodowych.

Niewątpliwie największym projektem zakupu autobusów elektrycznych na polskim rynku był projekt „Zakup taboru autobusowego (130 niskopodłogowych autobusów niskoemisyjnych) wraz z infrastrukturą towarzyszącą" realizowany przez Miejskie Zakłady Autobusowe w Warszawie. Projekt ten został dofinansowany z funduszy europejskich w ramach Programu Operacyjnego Infrastruktura i Środowisko na lata 2014-2020. Dokonano zakupu 130 autobusów przegubowych przeznaczonych do obsługi tras w ścisłym centrum miasta, a w ramach infrastruktury zabudowano sieć ładowarek do tzw. szybkiego ładowania, czyli ładowania autobusu na pętli końcowej, bez konieczności zjeżdżania do zajezdni. Całkowita wartość projektu osiągnęła ponad $411 \mathrm{mln}$ zł (MZA, 2021).

Autobus elektryczny (rysunek 4.9) wciąż uchodzi za pojazd innowacyjny, choć pojazdów tego typu eksploatuje się coraz więcej. Z punktu widzenia pasażera nie odbiega on mocno od innych pojazdów obsługiwanych przez przewoźników - zwykle bowiem zapewnia porównywalne do innych napędów wyposażenie funkcjonalne i podobny komfort podróży. Wyzwaniem jest dla operatora - nie tylko z uwagi na inny rodzaj napędu, ale przede wszystkim na ograniczony zasięg. A wybór strategii ładowania pojazdów i konsekwentne inwestycje w infrastrukturę mogą decydować o powodzeniu wdrożenia autobusów elektrycznych.

Na przykład w Warszawie, gdzie jak wspomniano wcześniej liczba autobusów elektrycznych osiągnęła poziom 160 sztuk, dostępne są ładowarki pantografowe do tzw. szybkiego ładowania pojazdów na sześciu pętlach autobusowych, a w czerwcu 2021 roku rozpoczęto budowę siódmej, największej stacji - sześć ładowarek o mocy prawie 2,5 megawata zaplanowano na pętli w Wilanowie. Ładowarki pantografowe są rozlokowane także w czterech zajezdniach (przy ul. Woronicza, Ostrobramskiej, 
Stalowej i Włościańskiej), w zajezdniach znajduje się też łącznie 160 ładowarek tzw. wolnego ładowania. Poprzez wtyczkę i połączenie kablowe umożliwiają one ładowanie akumulatorów pojazdów w trakcie nocnego postoju w zajezdni (UM Warszawa, 2021).

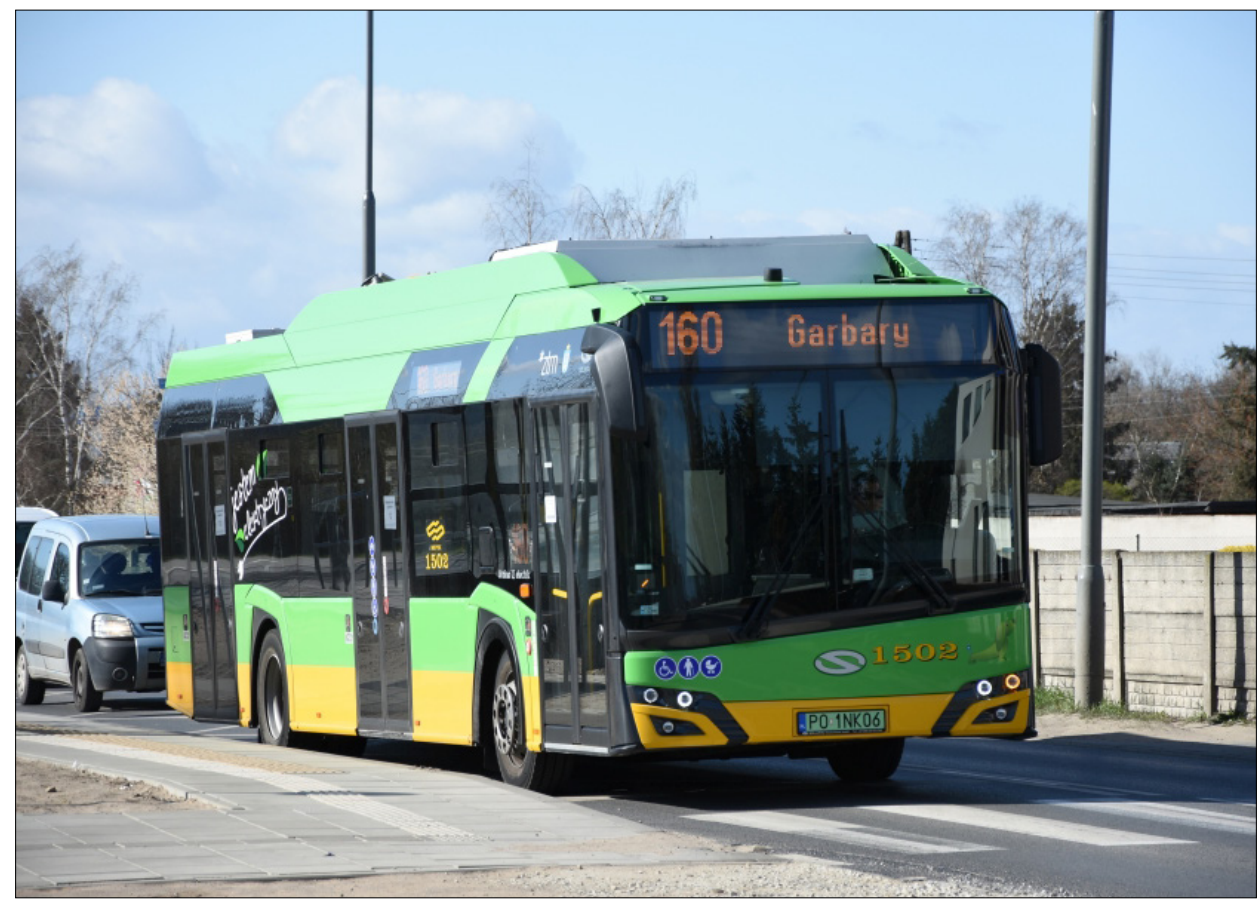

Rysunek 4.9. Autobus elektryczny w Poznaniu

Polska stała się ważnym punktem na europejskiej mapie producentów autobusów elektrycznych. W 2015 roku w Lublinie zawiązano spółkę Ursus Bus S.A., której głównym przedmiotem działalności była produkcja i sprzedaż autobusów - dwa lata później spółka powołała do życia konsorcjum „Polski E-BUS”, którego celem był stworzenie autobusu elektrycznego nowej generacji, wygrała także największy wówczas przetarg na autobusy elektryczne - 47 sztuk dla miasta Zielona Góra. Doświadczenie w produkcji i sprzedaży autobusów elektrycznych ma firma Solaris - wielokrotnie już wspominana w niniejszym opracowaniu. W Polsce produkcję autobusów elektrycznych realizuje także Volvo - egzemplarze modelu 7900 Electric trafiły między innymi do Luksemburga czy szwedzkiego miasta Malmo. Pojazdy te są produkowane od 2016 roku jako rozszerzenie i uzupełnienie dotychczasowej oferty autobusów hybrydowych. Wśród realizowanych projektów należy zwrócić także uwagę na program „e-Bus”, którego celem było skonstruowanie i wdrożenie do produkcji autobusów nowej generacji. Program realizowało Narodowe Centrum Badań i Rozwoju (Skalski, 2017). 


\section{Trolejbus z zasilaniem bateryjnym}

Trolejbusy są uznawane przez wielu specjalistów za pojazdy, które nie mają dziś większej przyszłości. Jako główny czynnik likwidacji sieci trolejbusowych podaje się argument ekonomiczny - utrzymywanie infrastruktury zasilającej generuje koszty, a w związku z dynamicznym rozwojem autobusów i coraz wyższą ich jakością dotychczasowa przewaga trolejbusów (cicha i płynna jazda, brak spalin) traci na znaczeniu. Jednym ze sposobów na rozwijanie sieci trolejbusowych pozostaje modyfikacja pojazdów, tak aby minimalizować niedogodności wynikające z konieczności eksploatacji pojazdów wyłącznie pod siecią trakcyjną.

Pierwsze trolejbusy $\mathrm{z}$ autonomicznymi źródłami zasilania pojawiły się w latach 80. XX wieku. Były to pojazdy wyposażone $\mathrm{w}$ agregaty spalinowe, $\mathrm{w}$ ramach prób wykorzystywano także baterie trakcyjne. Na szerszą skalę takie pojazdy zaczęto stosować na początku XXI wieku, przede wszystkim w Szwajcarii i we Włoszech (Połom, Piasecki, Bartłomiejczyk, 2015, s. 5395). Spośród ponad 150 sieci trolejbusowych w miastach europejskich doświadczenia z zasilaniem alternatywnym ma ponad 60 - najczęściej jest to agregat spalinowy, rzadziej baterie trakcyjne czy superkondensatorowe zasobniki energii. Pojazdy z zasilaniem alternatywnym proponuje dziś każdy liczący się producent trolejbusów (Połom, Piasecki, Bartłomiejczyk, 2015, s. 5398). Należy zauważyć, że statystyka ta pochodzi z publikacji sprzed kilku lat. Dziś udział przedsiębiorstw posiadających doświadczenia z pojazdami o napędzie czy zasilaniu pomocniczym jest znacznie większy. Ostatnie lata upłynęły pod znakiem gwałtownego rozwoju pojazdów elektrycznych i związanych z nimi ogniw baterii. Tym samym rozwiązania te są coraz bardziej doskonałe i zwiększają się możliwości ich wdrażania także w pojazdach transportu publicznego.

Jako przykład wdrożenia tego typu innowacji posłużyć może Przedsiębiorstwo Komunikacji Trolejbusowej w Gdyni. Chcąc uelastycznić sieć trolejbusową i zwiększyć jej niezawodność, poszukiwano możliwości wyposażenia pojazdów w autonomiczne źródło zasilania. Rozważano wprowadzenie autobusów wyposażonych w pomocniczy agregat spalinowy, baterie elektrochemiczne lub zasobnik superkondensatorowy. To ostatnie rozwiązanie oceniono negatywnie z uwagi na niewielką pojemność zasobnika. $Z$ kolei przeciw silnikom spalinowym przemawiał brak zaplecza technicznego i wykwalifikowanej kadry (operator obsługuje tylko i wyłącznie flotę trolejbusów $\mathrm{z}$ napędem elektrycznym). W związku z tym podjęto decyzję o zakupie trolejbusów z pomocniczym napędem akumulatorowym. Pierwsze pojazdy dostarczono w 2009 roku (2 sztuki), w kolejnym roku rozstrzygnięto postępowanie przetargowe na kolejne 25 sztuk (Bartłomiejczyk i Połom, 2011b). Jak wskazują Bartłomiejczyk i Połom (2011b), w standardowych warunkach i typowym ruchu ulicznym trolejbus ma możliwość przejechania na bateriach ok. 2,2 km (zakładając zalecane z punktu widzenia żywotności rozładowanie baterii w 20\%), a maksymalnie, przy większym rozładowaniu baterii, ponad $7 \mathrm{~km}$. 
Sam pomysł wspomagania napędu elektrycznego napędem pomocniczym nie jest nowy. Bartłomiejczyk i Połom (2011a) w przeprowadzonym badaniu już dziesięć lat temu stwierdzili, że spośród 155 sieci trolejbusowych w Europie 53 mają doświadczenie $\mathrm{z}$ wykorzystaniem alternatywnych źródeł zasilania - awaryjnie lub w regularnym ruchu, przywołując doświadczenia między innymi z Czech, Hiszpanii, Słowacji, Szwecji, Węgier czy Włoch.

Rozwój pojazdów ogumionych zasilanych energią elektryczną (zarówno trolejbusów, jak i autobusów elektrycznych) nakazuje poszukać odpowiedzi na pytania o rolę transportu trolejbusowego w miastach go posiadających czy o alternatywę dla trolejbusów. Czy podsystem trolejbusowy można dziś łączyć z autobusami elektrycznymi? A może wręcz rozwój technologii baterii trakcyjnych pozwala na całkowitą rezygnację z trolejbusów (Bartłomiejczyk, Goliszek i Połom, 2016)?

\section{Wodór + ogniwo paliwowe}

W 2021 roku Miejski Zakład Komunikacji w Koninie podpisał z Solaris Bus\&Coach umowę na dostawę jednego autobusu miejskiego zasilanego wodorem. Autobus ten ma być przez cztery lata dzierżawiony przez MZK i będzie pierwszym tego typu pojazdem eksploatowanym w Polsce (Wroński, 2021). Pojazd ma być dostarczony do Konina w 2022 roku. Na potrzeby użytkowania autobusu w Koninie do końca 2021 roku ma powstać pierwsza ogólnodostępna stacja tankowania wodoru w Polsce. Autobus Urbino 12 zostanie dostarczony przez firmę Solaris. Dotychczas zamówienia na autobusy wodorowe tego producenta złożyli przewoźnicy z Austrii, Holandii, Niemiec, Szwecji i Włoch - zamawiając łącznie ponad 80 pojazdów (Biskupska, 2021).

Konin nie jest jedynym miastem w Polsce, które chciałoby wprowadzić do eksploatacji pojazdy $\mathrm{z}$ takim napędem. Wniosek do NFOŚ o dofinansowanie takich pojazdów złożony został między innymi przez MPK Poznań - na zakup 84 autobusów wodorowych. Poziom dofinansowania ma osiągnąć $90 \%$. Wodór w opinii MPK jest przyszłością i ma być jednym z głównych sposobów rozwijania komunikacji autobusowej w Poznaniu (radiopoznan.fm, 2021). Dostawa 38 autobusów o długości 12 m i 46 autobusów przegubowych mogłaby zostać zrealizowana w latach 2022-2025 Mają to być pojazdy wyposażone w ogniwa paliwowe. Taki pojazd był już testowany w Poznaniu. Solaris Urbino 12 hydrogen posiada na dachu zbiorniki, w których jest magazynowany wodór w postaci gazowej, pod ciśnieniem 350 atmosfer. Na pokładzie autobusu z wodoru wytwarzana jest energia elektryczna - przekazywana następnie do układu napędowego i niewielkiej baterii. Rolą baterii jest wsparcie ogniwa paliwowego w chwilach największego zapotrzebowania na energię elektryczną. Bateria jest ładowana także przy hamowaniu, a pojazd emituje do środowiska tylko parę wodną. Równolegle trwają pierwsze rozmowy na temat możliwości tankowania wodorem takich pojazdów - zarówno z wykorzystaniem stacji, które byłyby ogólnodostępne, jak i specjalnej stacji, która mogłaby powstać dla pojazdów MPK (MPK Poznań, 2021b). 
W grudniu 2021 roku poinformowano, że MPK Poznań uzyskało dofinansowanie na zakup 25 autobusów wodorowych o długości $12 \mathrm{~m}$, a dofinansowanie projektu z programu Zielony Transport ma wynieść prawie $68 \mathrm{mln}$ zł (Rösler, 2021a).

Autobusy zasilane wodorem mogą się pojawić także na ulicach Warszawy. W planach Miejskich Zakładów Autobusowych - największego przewoźnika autobusowego na stołecznych ulicach - jest wdrożenie do eksploatacji krótkiej serii 5-10 autobusów wodorowych. MZA uzasadnia zakup jedynie małej partii takich pojazdów względami ekonomicznymi. Według wyliczeń MZA szacunkowy koszt eksploatacji autobusu wodorowego w trakcie jego 10-letniej eksploatacji ( 800 tys. $\mathrm{km}$ ) wyniesie dwa razy więcej niż koszt eksploatacji autobusu elektrycznego. Wysoki koszt eksploatacji to efekt między innymi braku na krajowym rynku dostawcy „czystego” wodoru, tj. wodoru, który nie byłby produktem ubocznym w zakładach przemysłowych, wymagającym dodatkowego, kosztownego oczyszczenia (Rösler, 2021b).

Napędy wodorowe są dziś najbardziej „gorącym” trendem, jeżeli chodzi o paliwa alternatywne. Choć tego typu pojazdy nie pojawiły się jeszcze na polskich drogach, toczy się intensywna dyskusja na temat możliwości ich użytkowania. A starania o dofinansowanie są podejmowane między innymi w ramach programu "Nowa Energia” realizowanym przez Narodowy Fundusz Ochrony Środowiska i Gospodarki Wodnej. Do kolejnego etapu oceny wniosków w projekcie przeszło sześć wniosków o dofinansowanie. Wśród nich jest spółka PAK-PCE Polski Autobus Wodorowy, w czerwcu 2021 roku ZE PAK podpisał list intencyjny z Miejskim Przedsiębiorstwem Komunikacyjnym na dostawę wodoru - Lublin potwierdził tym samym, że jest jednym z miast mających plany eksploatacji pojazdów zasilanych tym paliwem (Madrjas, 2021).

\section{Napędy alternatywne w pojazdach szynowych}

Choć hasło „napędy alternatywne” jest zwykle utożsamiane z pojazdami autobusowymi, nie brakuje innowacyjnych wdrożeń w tym obszarze obejmujących pojazdy szynowe. I choć w niniejszej publikacji skupiono się na rozwiązaniach głównie w zakresie mobilności miejskiej i aglomeracyjnej, warto zasygnalizować przykładowe innowacje w sektorze kolejowym.

Pojazdy dwutrakcyjne od lat są skutecznym sposobem na zapewnienie większej elastyczności systemów transportu publicznego i poszerzenie możliwości integracji różnych form i środków transportu. Jako przykład pojazdu tramwajowego z dodatkowym silnikiem spalinowym może posłużyć tramwaj Siemens Combino Duo z Nordhausen. Przedsiębiorstwo Verkehrsbetriebe Nordhausen wykorzystuje takie pojazdy do obsługi linii tramwajowej nr 10 łączącej szpital w Nordhausen z Neanderklinik w Ilfeld - 11-kilometrowa trasa wiedzie częściowo niezelektryfikowanymi odcinkami torów kolejowych, na których tramwaj przełącza się na zasilanie dieslowskie (Regional Verkehr, 2004).

W 2021 roku ogłoszono, że PESA - polski producent taboru - pracuje nad lokomotywą zasilaną wodorem. Projekt powstaje we współpracy z koncernem paliwo- 
wym - PKN Orlen. Prace nad pojazdem trwają od dwóch lat (businessinsider.com, 2021). Zaprezentowano go we wrześniu 2021 roku na targach kolejowych TRAKO. To pierwszy na polskim rynku projekt wykorzystania wodoru w transporcie szynowym, co nie oznacza, że jest to pierwszy tego typu projekt na rynku europejskim.

W 2016 roku na targach InnoTrans w Berlinie koncern Alstom zaprezentował pociąg Coradia iLint - skład pociągu regionalnego przedstawiony jako pierwszy na świecie pociąg pasażerski zasilany alternatywnym dla tradycyjnych silników diesla napędem wodorowym. Dwa lata później, w 2018 roku, pojazd wprowadzono do ruchu pasażerskiego w Niemczech. Dzięki zastosowaniu napędu opartego na ogniwach paliwowych pojazd jest określany jako zeroemisyjny. Projekt był realizowany przez zespoły Alstom z Niemiec i Francji przy wsparciu niemieckich władz państwowych, chociażby poprzez narodowy program wsparcia innowacji w ogniwa paliwowe i technologie wodorowe (alstom.com, 2021a). W czerwcu 2021 roku innowacyjny pociąg przyjechał do Polski, gdzie przechodzi próby na torze testowym w Żmigrodzie. Pojawienie się pojazdu w Polsce zbiegło się z ogłoszeniem planów rozwoju niskoemisyjnego transportu kolejowego (alstom.com, 2021b).

Po długim okresie testów na 123-kilometrowej trasie w Dolnej Saksonii w marcu 2022 roku 14 pociągów zasilanych wodorem wejdzie do obsługi linii pomiędzy Buxtehude koło Hamburga a nadmorskim miastem Cuxhaven. Od pięciu lat Alstom promuje pociągi zasilane ogniwami paliwowymi jako alternatywę dla silników dieslowskich i ma na koncie sukcesy: wspomniany projekt niemiecki, a także pierwsze zamówienie od narodowych kolei francuskich na hybrydowe, wodorowo-elektryczne pociągi, zamówienie na 27 pociągów dla niemieckiego RMV i 6 pociągów (z planami kolejnych 8) do Włoch (fortune.com, 2021).

\section{Zasilanie bateryjne w pojazdach szynowych}

Jako przykład innowacji może także posłużyć warszawska próba przebudowy klasycznego wagonu tramwajowego na wagon zasilany bateryjnie. Modernizacja ta została przeprowadzona $\mathrm{w}$ tramwaju typu $116 \mathrm{~N} \mathrm{nr} 3002$ i miała dać odpowiedź na pytanie, na ile możliwe jest wykorzystanie tramwaju zasilanego bateryjnie w normalnej eksploatacji miejskiej.

W 2005 roku podjęto prace projektowe nad przebudową tramwaju na zasilanie bateryjne. Tramwaje Warszawskie wspólnie z Instytutem Elektrotechniki przygotowały projekt modyfikacji układu elektrycznego tramwaju. W wagonie zamontowano akumulatory niklowo-kadmowe, lokalizując je w wysokopodłogowej części wagonu pod siedzeniami. Pojazd wyposażono w dodatkowe urządzenia kontrolne (aby dać motorniczemu możliwość nadzoru nad wykorzystywanym sposobem zasilania). Pierwsze próby przeprowadzono w sierpniu 2005 roku, we wrześniu 2005 roku odbywały się jazdy pokazowe. W październiku 2005 roku wagon trafił do codziennej eksploatacji. Baterie akumulatorów usunięto z tramwaju w 2008 roku, a wagon stał się ponownie „klasycznym”, typowym wagonem liniowym (Tramwar.pl, 2021). 
W innych polskich miastach nie realizowano dotychczas takich projektów tramwaje pozostają zasilane z napowietrznej sieci trakcyjnej, choć coraz częściej w nowych wagonach standardem jest możliwość awaryjnego zjazdu spod izolatora sieci trakcyjnej lub ze skrzyżowania $\mathrm{z}$ wykorzystaniem standardowo montowanych akumulatorów. Inaczej wygląda kwestia zasilania bateryjnego pojazdów spalinowych - tu standardem staje się wspieranie zasilaniem bateryjnym trolejbusów, wspomniane we wcześniejszym podrozdziale.

\subsection{Systemy informatyki i automatyki dla operatora i organizatora transportu}

Cyfryzacja i digitalizacja jest jednym z wyraźniej zaznaczających się trendów w gospodarce XXI wieku. Podobnie jest w branży transportu publicznego, gdzie można zauważyć dynamiczny rozwój zarówno systemów automatyki, jak i systemów informatycznych. W niniejszym podrozdziale przedstawiono kilka grup rozwiązań wykorzystywanych w ramach szeroko rozumianej cyfryzacji transportu publicznego. Obszar ten jest niezwykle dynamiczny i praktycznie każdy rok przynosi nowe rozwiązania dotyczące systemów informatycznych dla transportu publicznego.

Wdrażanie systemów informatycznych należy rozpatrywać na dwóch płaszczyznach. Pierwsza to digitalizacja procesów, związana $\mathrm{z}$ wdrażaniem narzędzi informatycznych zamiast innych narzędzi lub dodatkowo - celem usprawnienia procesów biznesowych czy poprawy jakości usług (lub jednego i drugiego). Drugi element to wprowadzenie rozwiązań o charakterze mobilnym - dzięki powszechności urządzeń mobilnych systemy informatyczne coraz częściej pozwalają na dostęp mobilny. Tym samym możliwa jest komunikacja pomiędzy systemem a użytkownikiem (jedno- lub dwukierunkowa, w zależności od kontekstu biznesowego) z pominięciem jakichkolwiek ograniczeń przestrzennych, czasowych czy lokalizacyjnych.

W niniejszym podrozdziale przedstawiono kilka podstawowych typów narzędzi informatycznych wykorzystywanych przez operatorów i organizatorów transportu. Ponieważ są one często rozwiązaniami wdrożonymi dopiero w ostatnich latach lub też podlegają dopiero wdrożeniu, z powodzeniem można je uznać za innowacje.

Jako najtrudniejsze, ale też i najciekawsze problemy z punktu widzenia planowania (zarówno strategicznego, jak i operacyjnego) należy uznać problemy z zakresu optymalizacji. Planowanie, dyspozycja i kontrola, a także rozliczanie stanowią dla licznych flot pojazdów operujących z wielu lokalizacji wyzwanie logistyczne wymagające wykorzystania techniki informatycznej (Kisielewski, 2017, s. 81).

Powszechnie wykorzystywane jest pojęcie „inteligentnych systemów transportowych" odnoszące się do wszelkich rozwiązań informatycznych ułatwiających 
i usprawniających funkcjonowanie systemów transportowych. Pojęcie to jest bardzo pojemne, w Polsce zwykło się nim nazywać systemy informatyczne wspierające zarówno transport publiczny, jak i ruch samochodowy. W obu przypadkach można mówić o jednej grupie systemów - bowiem obie te grupy użytkowników korzystają przecież z tej samej miejskiej przestrzeni. Praktycznie każde duże polskie miasto ma już spore doświadczenia w tym zakresie.

Zgodnie z definicją inteligentne systemy transportowe mogą świadczyć szeroki zakres usług obejmujący między innymi:

- obsługę rynku,

- zarządzanie ruchem,

- zarządzanie pojazdami,

- zarządzanie transportem publicznym,

- zarządzanie bezpieczeństwem,

- elektroniczny pobór opłat,

- obsługę klienta (Tomaszewska, 2015, za: Wojewódzka-Król i Rolbiecki, 2010).

W niniejszym opracowaniu skupiono się na tych elementach, które dotyczą stricte transportu publicznego - ruchu pojazdów komunikacji publicznej czy też wsparcia w świadczeniu tych usług w jakiejkolwiek formie. Stąd miejsce na systemy dynamicznej informacji pasażerskiej, systemy dyspozytorskie, systemy zarządzania pojazdami itp.

\section{Dynamiczne systemy informacji pasażerskiej}

System dynamicznej informacji pasażerskiej to jeden z bardziej widocznych przykładów innowacji związanych $\mathrm{z}$ informatyzacją procesów w transporcie publicznym. W ostatnich latach na ulicach zdecydowanej większości polskich miast pojawiły się elektroniczne tablice informacyjne przekazujące pasażerom informacje o czasie przyjazdu pojazdu na przystanek.

Należy zwrócić uwagę na fakt, że choć są to najbardziej widoczne elementy systemu dynamicznej informacji pasażerskiej, to pełnią jedynie funkcję urządzeń „wyjściowych" dla danych z takiego systemu. Tym samym brak odpowiedniej treści do wyświetlenia sprawia, że ich funkcjonalność jest ograniczona. A jeżeli taka informacja miałaby pokazywać tylko i wyłącznie rozkładowy czas przyjazdu na przystanek - można ją uznać za porównywalną pod względem funkcjonalności do tradycyjnego rozkładu jazdy.

„Sercem” systemu dynamicznej informacji pasażerskiej jest zatem system informatyczny, który zbiera informacje na temat położenia pojazdów i prognozuje czas przyjazdu na przystanek. Oczywiście dane te mają charakter prognozy, dzięki odpowiednim algorytmom ma to być jednak prognoza możliwie bliska rzeczywistości.

$\mathrm{W}$ ostatnich latach upowszechniły się także aplikacje mobilne pozwalające przenieść funkcjonalność tablicy przystankowej na ekran telefonu komórkowego. 
Rozwiązanie to ma kilka podstawowych zalet. Po pierwsze, $w$ dobie taniego dostępu do transmisji danych za pośrednictwem operatorów komórkowych pozwala ono w łatwy i praktycznie bezkosztowy sposób korzystać z udogodnienia użytkownikom telefonów komórkowych. Po drugie, zwykle aplikacje są na tyle uniwersalne, by z powodzeniem wykorzystywali je użytkownicy typowych smartfonów z popularnymi systemami operacyjnymi. Po trzecie, zwłaszcza na obszarach peryferyjnych, gdzie ekonomicznie nieuzasadnione byłoby inwestowanie w drogie, przystankowe tablice elektroniczne, aplikacja mobilna daje dostęp do informacji o kursowaniu pojazdów komunikacji publicznej w czasie rzeczywistym.

Niezwykle ważnym elementem jest zapewnienie otwartego dostępu do danych na temat pojazdów komunikacji publicznej. Poczynienie odpowiednich założeń już na etapie budowania systemu informatycznego do zarządzania ruchem pojazdów i informacji pasażerskiej pozwala później tworzyć aplikacje mobilne także podmiotom niezależnym, co daje możliwość udostępnienia pasażerom nowych, ciekawych aplikacji mobilnych, nie zawsze bezpośrednio związanych $\mathrm{z}$ operatorem systemu czy organizatorem transportu.

Przykładowe zrzuty ekranu z dwóch aplikacji mobilnych służących udostępnianiu informacji pasażerom przedstawiono na rysunku 4.10. Na zdjęciu lewym aplikacja Wirtualny monitor, a na niej "tablica przystankowa” z godzinami odjazdów pojazdów (dane dynamiczne są oznaczone dopiskiem „GPS”). Na zdjęciu prawym widok mapy w aplikacji Kiedy pojadę - obok funkcji „tablicy przystankowej” ta aplikacja pozwala wyświetlić pojazdy na mapie wraz z ich numerem taborowym, aktualną prędkością jazdy, najbliższym przystankiem oraz linią i kierunkiem jazdy.
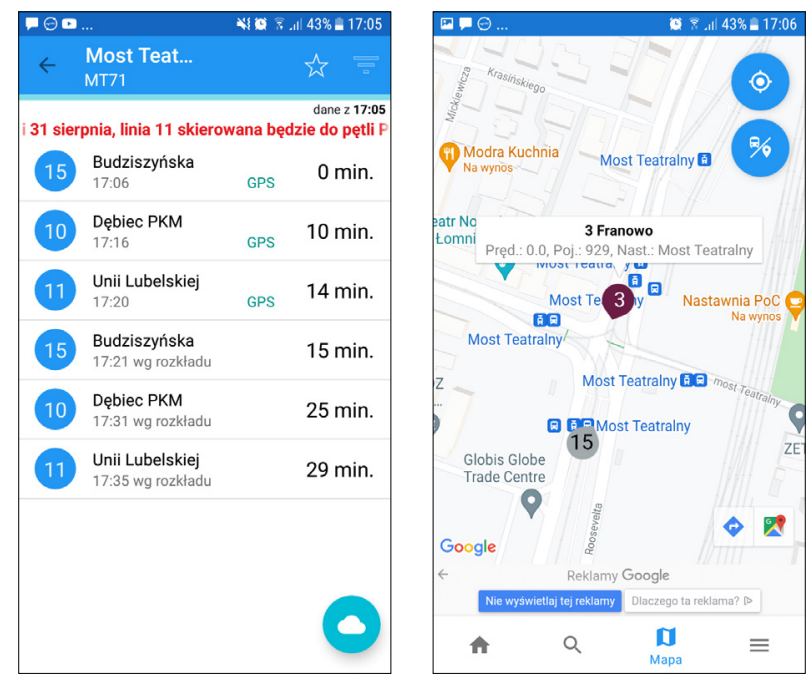

Rysunek 4.10. Aplikacje mobilne dla pasażerów - Wirtualny monitor i Kiedy pojadę

Źródło: Wirtualny monitor i Kiedy pojadę. 


\section{Systemy zarządzania ruchem / systemy dyspozytorskie}

System dynamicznej informacji pasażerskiej został wskazany jako pierwszy, w praktyce jest jednak nierozerwalnie związany z systemami o charakterze dyspozytorskim. Zadaniem tych systemów jest nadzorowanie ruchu pojazdów i bieżące reagowanie na zakłócenia w ruchu. Systemy te korzystają zatem z tych samych danych co systemy informacji pasażerskiej - bieżącej lokalizacji pojazdów.

System dynamicznej informacji pasażerskiej jest zwykle zasilany danymi z systemu dyspozytorskiego. Ten ostatni daje też możliwość udostępnienia pasażerom dodatkowych danych (na przykład komunikatów o utrudnieniach w ruchu). Zadaniem systemu dyspozytorskiego i systemów mu towarzyszących (na przykład zewnętrznego systemu łączności) jest utrzymanie w ruchu pojazdów tworzących system transportu publicznego.

Na rysunku 4.11 przedstawiono przykładowy widok z centrum dyspozytorskiego we Wrocławiu przy ul. Strzegomskiej. Inżynierowie i dyspozytorzy z Centrum Zarządzania Ruchem i Transportem Publicznym odpowiadają między innymi za utrzymanie płynności kursów komunikacji publicznej i ruchu drogowego (Wroclaw. $\mathrm{pl}, 2016)$.

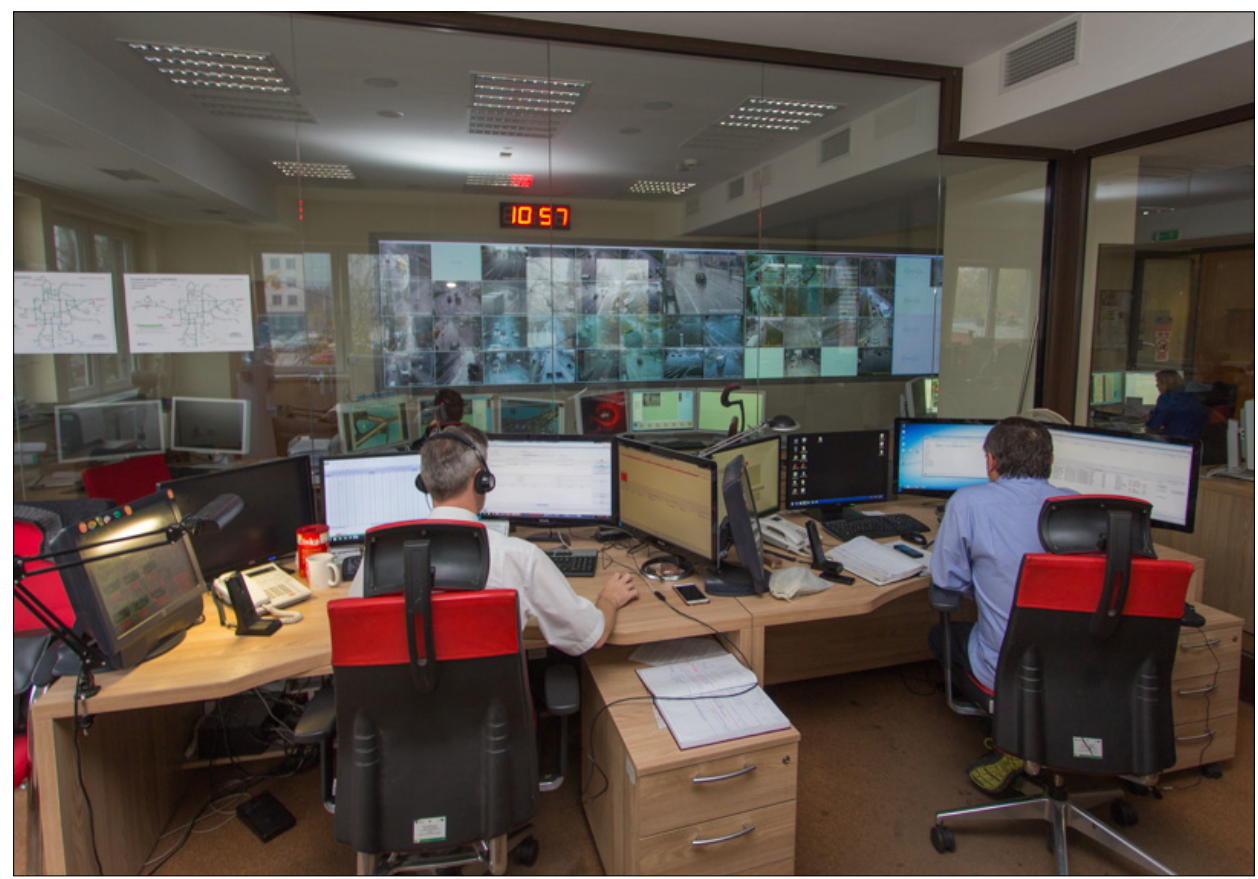

Rysunek 4.11. Dyspozytorzy MPK w Centrum Zarządzania Ruchem i Transportem Publicznym we Wroclawiu

Źródło: (Wroclaw.pl, 2016). 
Jako przykład wdrożenia systemu tego typu może posłużyć wdrożenie operatorskiego systemu zarządczego obejmującego flotę 1500 pojazdów w Miejskich Zakładach Autobusowych w Warszawie. Całość rozwiązania informatycznego składa się z szeregu aplikacji funkcjonalnych wykonywanych przez różne firmy, ale zgodnie z założeniami i wymaganiami - zarówno operatora, jak i współpracującego zespołu naukowców z Politechniki Warszawskiej. Historia systemów dyspozytorskich sięga w MZA 1986 roku, kiedy to uruchomiono system ASTER obejmujący flotę 180 autobusów lokalizowanych logicznie na podstawie danych dotyczących pokonywanej drogi i sygnałów o otwarciu drzwi przekazywanych z wykorzystaniem analogowej łączności radiowej (Suda, 2017).

Obecnie system wykorzystywany przez MZA obejmuje 11 aplikacji funkcjonalnych, a w przygotowaniu jest kolejna aplikacja, niezbędna do zarządzania pojazdami elektrycznymi (Suda, 2017). Sercem systemu jest oprogramowanie „Serwera Łączności Alarmowej" służące do odbierania i nadawania komunikatów oraz zarządzania danymi i komunikacją. Producenci autobusów dostosowują się tu do własnego standardu komunikatów MZA. Aplikacja Mapa służy do obrazowania lokalizacji pojazdów na podkładzie mapowym - wraz $\mathrm{z}$ alarmami i informacją o odchyleniu od rozkładu jazdy, z kolei aplikacja Odchyłka jest narzędziem pracy dyspozytorów nadzorujących ruch pojazdów liniowych. Aplikacja WIA służy do obsługi wypadków i awarii, a aplikacja STP (System Telemetrii Pojazdowej) zbiera z pojazdów informacje o zagrożeniach i wybranych parametrach eksploatacyjnych. Do lokalizowania pojazdów na polach postojowych zajezdni służy aplikacja Infodriver - udostępniająca też bieżące informacje kierowcom. W ciągu 10 lat System Zarządzania Pojazdami MZA budowały 4 firmy inżynierskie oraz 5 firm informatycznych - realizując projekty, procedury, algorytmy stworzone przez zespół pracowników MZA oraz Wydziału Transportu Politechniki Warszawskiej (Suda, 2017).

\section{Systemy wyszukiwania połączeń / tras / pojazdów (planery podróży)}

Aplikacje tego typu są obecne w transporcie publicznym od wielu lat i zgromadziły setki tysięcy użytkowników. Przykładowo portal jakdojade.pl działa od 2008 roku, a już zaledwie rok później miał 240 tys. użytkowników i trafił do rankingu „Top 10 startups" (MamBiznes.pl, 2009).

Podstawowym zadaniem aplikacji tego typu jest wyznaczanie trasy przejazdu i możliwych połączeń pomiędzy punktami A i B. W praktyce narzędzia tego typu ewoluowały i coraz częściej pozwalają nie tylko na określenie trasy przejazdu z możliwościami przesiadki, ale i personalizowanie podróży (poprzez wybór preferowanych tras, linii, typów środków transportu) czy oszacowanie jej kosztów poprzez podanie wartości koniecznych do zakupu biletów (rysunek 4.12).

O tych aplikacjach należy wspomnieć w jeszcze jednym kontekście - wszystkie obecne na rynku narzędzia tego typu działają dziś w ramach statycznego rozkładu jazdy. Nie mają zatem informacji na temat rzeczywistego położenia pojazdu i realizacji rozkładu jazdy. W perspektywie podróży z przesiadkami oznacza to, że 
planer przedstawia drogą teoretyczną, bez korygowania danymi rzeczywistymi. Takie podejście jest naturalne - narzędzia tego typu rozwijały się, gdy systemy dyspozytorskie pozwalające na dynamiczne informowanie o lokalizacji pojazdów nie były jeszcze rozpowszechnione.

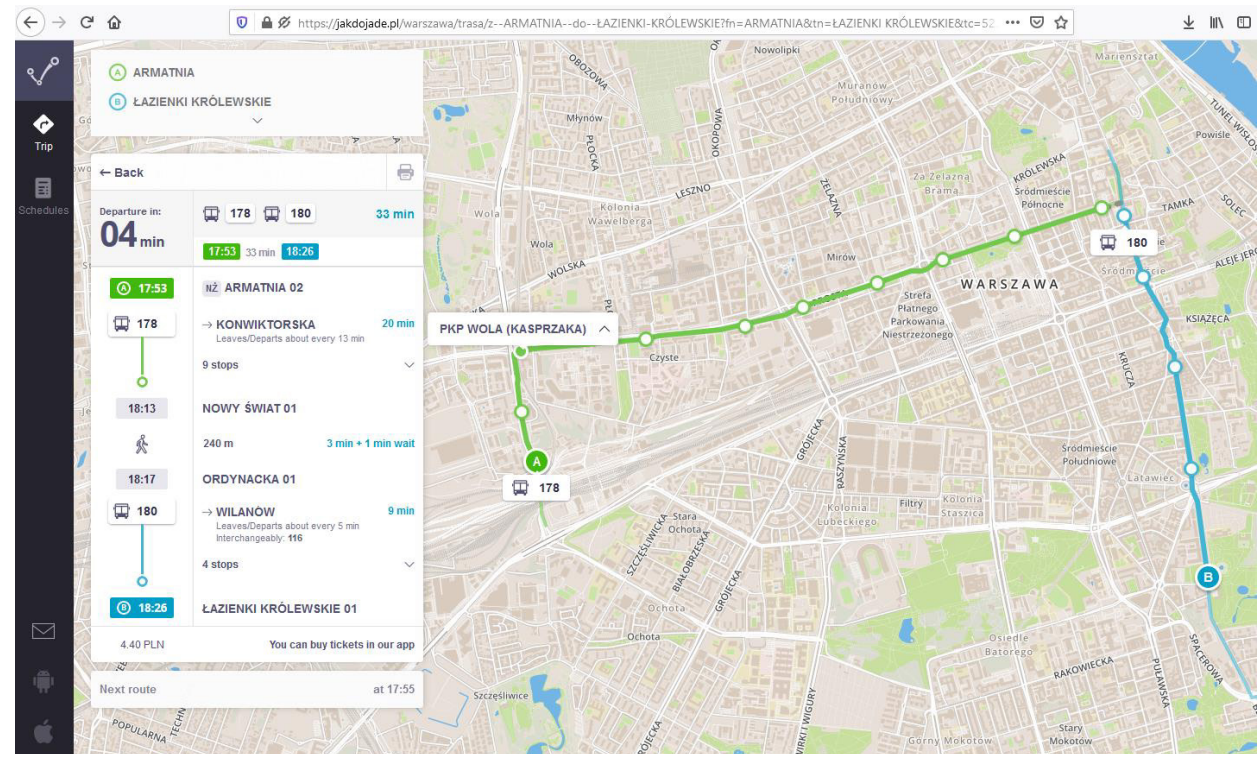

Rysunek 4.12. Przykładowa trasa przejazdu w planerze podróży Jak dojadę

Źródło: (jakdojade.pl, 2021).

Jako innowację, która pojawi się w najbliższych latach należy zatem uznać narzędzia, które połączą planowanie podróży z dynamiczną, rzeczywistą informacją na temat poruszania się pojazdów. Będzie to analogiczne do systemów nawigacji satelitarnej służących do wyznaczania trasy przejazdu samochodem - tak by zarówno zaplanować podróż, jak i móc ją później zmieniać zgodnie z aktualną sytuacją komunikacyjną.

\section{Systemy zajezdniowe}

Kolejną grupą systemów informatycznych, jakie są wdrażane przez przedsiębiorstwa transportu publicznego, są systemy do zarządzania procesami biznesowymi, a wśród nich systemy do obsługi pojazdów i infrastruktury zajezdni.

Pierwszą zajezdnią wyposażoną $\mathrm{w}$ informatyczny system zarządzania była zajezdnia MPK Poznań na Franowie. Zadaniami takiego systemu są między innymi: automatyczne ustawianie wagonów, kierowanie pojazdów do warsztatu naprawczego, nadzór nad realizacją przeglądów cyklicznych. Aktualny podgląd infrastruktury zajezdni jest widoczny na ekranie w postaci graficznej. Wagony uszkodzone czy kierowane do myjni są oznaczane innymi kolorami. Motorniczowie nie muszą ręcznie 
przekładać zwrotnic, ponieważ tramwaj jest kierowany przez system na odpowiedni tor. To wyklucza ryzyko kolizji, gdyż na czas przejazdu zidentyfikowanego tramwaju tor jest dla niego „rezerwowany”. Do komunikacji motorniczych z dyspozytorem wykorzystuje się interkomy (MPK Poznań, 2012).

\section{Systemy klasy ERP}

Wymieniając innowacje $\mathrm{w}$ transporcie publicznym, należy wskazać także systemy klasy ERP. I choć w świecie informatycznym tego typu systemy są coraz rzadziej uznawane za nowatorskie i innowacyjne, a stają się rynkowym standardem, w warunkach funkcjonowania przedsiębiorstw komunikacji publicznej system klasy ERP stanowi ważny etap digitalizacji procesów. Tym samym należy go traktować nie tylko jako innowację produktową, ale przede wszystkim jako towarzyszącą mu innowacją procesową.

Systemy tego typu wdrażane w przedsiębiorstwach transportu publicznego mogą mieć dwojaki charakter - mogą być klasycznymi systemami typu ERP lub systemami wyposażonymi w przeznaczone do transportu publicznego moduły dodatkowe - specyficzne dla procesów realizowanych w przedsiębiorstwach transportu publicznego.

\section{Systemy biletowe i taryfowe (karty miejskie i aglomeracyjne)}

Systemy taryfowe i biletowe stanowią nieodłączną część systemu transportu publicznego. Zasadniczo nie ma w nich innowacji procesowych czy organizacyjnych, jednak dziś mogą już stanowić ciekawą innowację w efekcie stosowanych rozwiązań technicznych. Dostęp na szeroką skalę do systemów płatności bezgotówkowych sprawie, że także w polskich miastach jest coraz więcej rozwiązań wspierających płatności (chociażby zbliżeniowe). Jako przykład może posłużyć prezentowany na rysunku 4.13 automat biletowy w pojeździe MPK Wrocław.

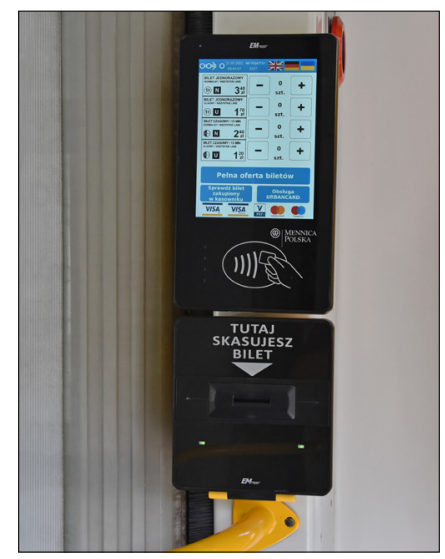

Rysunek 4.13. Automat biletowy w pojeździe MPK Wrocław 
Systemy zarządzania ruchem ( $w$ tym priorytet dla pojazdów komunikacji miejskiej), detekcja pojazdów

Zarządzanie ruchem drogowym jest bardzo często wskazywane jako jeden z podstawowych elementów systemów klasy ITS. Rola tego typu narzędzi w upłynnianiu ruchu pojazdów jest nieoceniona, a mnogość stosowanych technologii pozwala na dopasowanie wdrożenia do indywidualnych potrzeb ośrodków miejskich.

Na przykład wdrożony w 2015 roku system klasy ITS w Białymstoku wprowadził sterowanie sygnalizacją świetlną na 120 skrzyżowaniach, wraz z powiązanymi funkcjonalnościami: pierwszeństwem dla pojazdów komunikacji miejskiej czy wyświetlaniem informacji na tablicach zmiennej treści. Funkcjonowanie sygnalizacji świetlnej jest dostosowywane do aktualnego natężenia ruchu, co ma zapewniać sprawniejsze poruszanie się po mieście - zarówno samochodów, jak i miejskich autobusów. System wspiera 120 kamer monitoringu CCTV dającego operatorom bieżący podgląd na aktualną sytuację drogową (Tomaszewska, 2015).

Z kolei w Rzeszowie, w ramach Inteligentnego Systemu Transportowego, uruchomiono: system dynamicznej informacji pasażerskiej, system zarządzania transportem publicznym, bilet elektroniczny dla komunikacji miejskiej oraz system obszarowego sterowania ruchem drogowym. Założeniem było tu stworzenie systemu o kompleksowym działaniu, a jako korzyści z wdrożenia ITS wskazuje się zwiększenie przepustowości sieci ulic o 20-25\%, poprawę bezpieczeństwa ruchu drogowego, skrócenie czasu podróży czy zmniejszenie zużycia energii (Nowotyńska i Kut, 2016).

Jako ciekawy przykład innowacji może posłużyć rozwiązanie wykorzystywane we Wrocławiu (rysunek 4.14). Na wielu skrzyżowaniach zamontowano tam tzw. sekundniki - odliczające czas czerwonego i zielonego sygnału. Rozwiązanie to służy poprawie płynności ruchu - kierowca $\mathrm{z}$ wyprzedzeniem wie, kiedy zapali się zielone lub czerwone światło.

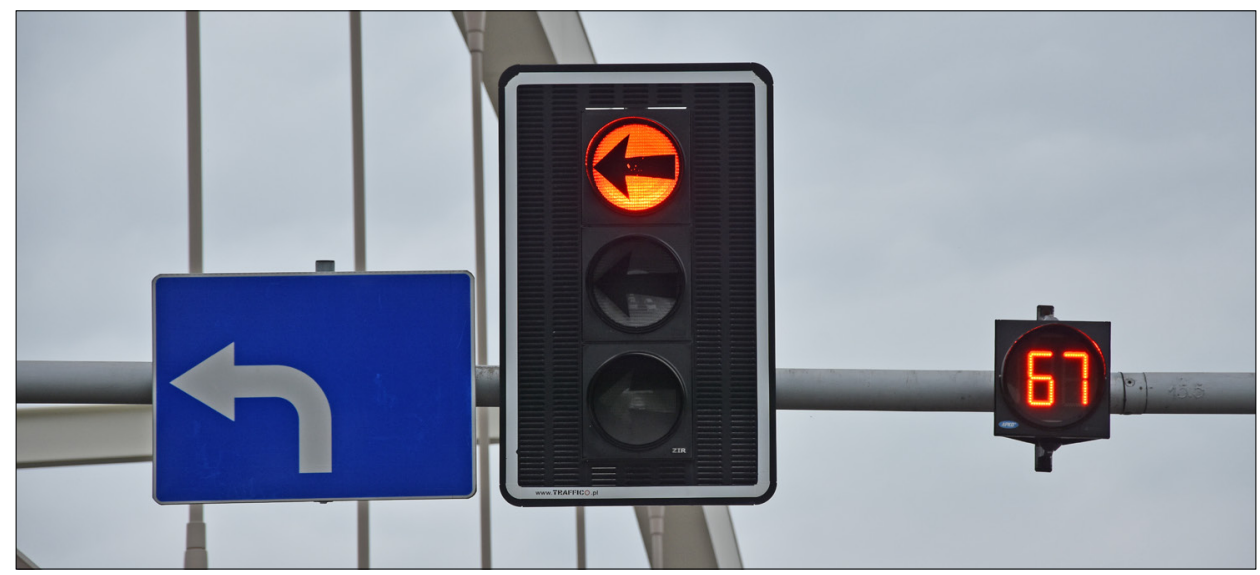

Rysunek 4.14. Sygnalizacja świetlna z sekundnikiem, Wrocław 


\section{Systemy i urządzenia automatyki torowej}

Wśród innowacji o charakterze infrastrukturalnym często są wskazywane automatyczne mechanizmy przekładania zwrotnic. Jeszcze kilkanaście lat temu standardem było ręczne przekładanie zwrotnic przez prowadzących pojazdy. I choć zasadniczo idea tego typu rozwiązań automatyki pozostaje od lat taka sama, to zmieniają się mechanizmy sterowania zwrotnicami i systemy sterujące automatyką.

Za montażem urządzeń do automatycznego przekładania zwrotnic przemawiają przede wszystkim: wygoda użytkowania, oszczędność czasu prowadzących pojazdy, a także kwestia bezpieczeństwa. Samo bezpieczeństwo jest tu rozumiane dwojako: jako zmniejszenie ryzyka wypadków przy pracy (związanego z wychodzeniem prowadzących pojazd na wydzielone torowisko tramwajowe, co zwłaszcza w sezonie jesienno-zimowym grozi poślizgnięciem i kontuzją), ale także jako zwiększenie bezpieczeństwa ruchu - nowoczesne systemy automatyki torowej wprowadzają elektroniczne i mechaniczne blokady zwrotnic. A dodatkowe ryglowanie zwrotnicy uniemożliwia przełożenie jej pod przejeżdżającym pojazdem.

W polskich przedsiębiorstwach komunikacji miejskiej nowoczesne rozwiązania informatyki i automatyki zaczęły się pojawiać na szerszą skalę w latach 90 . XX wieku - wraz z upowszechnieniem się chociażby komputerów klasy PC. Dotyczyło to zarówno pierwszych urządzeń tzw. automatyki torowej rozproszonych na sieci komunikacyjnej, jak i systemów informatycznych o charakterze centralnym.

W Poznaniu pierwszy mechanizm zwrotnicowy z mechanicznym i elektrycznym systemem ryglowania umożliwiającym przełożenie zwrotnicy pod przejeżdżającym tramwajem zamontowano w 1991 r. - na ul. Roosevelta, od strony Mostu Dworcowego (Wojcieszak, 2000, s. 92). Lata 90. upłynęły także pod znakiem pierwszych sygnalizacji świetlnych sterowanych przez tramwaje (najechanie na płytę indukcyjną w torowisku). Montowano także (Rondo Kaponiera, Most Teatralny) pierwsze sygnalizacje świetlne sterowane nadajnikiem radiowym TRACK 200 (Wojcieszak, 2000, s. 96), gdzie motorniczy mógł samodzielnie (odpowiednim przyciskiem w kabinie) zgłosić żądanie wyświetlenia sygnału jazdy w zdefiniowanym przez siebie kierunku. „Pod koniec lat 90. oddano również do użytku system Komputerowego Wspomagania Sterowania Ruchem, który umożliwia kontrolę ruchu w czasie rzeczywistym wszystkich autobusów poruszających się po mieście. Komputer centralny w cyklu dwuminutowym przepytuje wszystkie pojazdy, zbierając informacje o miejscu ich położenia i odchyleniach od rozkładu jazdy. Ponadto komputer pokładowy steruje pracą wszystkich urządzeń w pojeździe, takich jak kasowniki, wyświetlacze nazwy następnego przystanku, tablice kierunkowe i systemy zapowiedzi akustycznej. Dzięki wyposażeniu autobusów w autokomputer i elektroniczne kasowniki MPK Poznań wprowadziło w 1999 roku nowy typ biletu - bilet przystankowy" (Wojcieszak, 2000, s. 9-10). W tym czasie zakończono także budowę systemu Centralnej Dyspozytorni Mocy, nadzorującej sieć energetyczną na terenie miasta. 
Ostatnim pomysłem wdrażanym w przedsiębiorstwach komunikacji miejskiej jest wykorzystanie sygnału radiowego do detekcji w przypadku pojazdów autobusowych. Detekcja z wykorzystaniem tzw. sygnału VDV jest realizowana od 2018 roku w sieci ZTM Poznań dla autobusów miejskich - nie jest potrzebny do tego wydzielony buspas. Autokomputer autobusu daje sygnał do sterownika sygnalizacji świetlnej, a sterownik może rozpocząć fazę zielonego światła lub ją wydłużyć (radiopoznan.fm, 2021).

Należy zwrócić uwagę, że urządzenia automatyki torowej dają także możliwość integracji z systemami sterowania i zarządzania ruchem, co pozwala na wytyczenie trasy dla przejeżdżającego pojazdu i przełożenie zwrotnic w sposób automatyczny. Rozwiązanie takie wprowadzono między innymi w ramach systemu ITS w Poznaniu.

\section{Przyszłość systemów informatycznych}

Branża informatyczna pozostaje obszarem niezwykle szybkiego rozwoju. Powszechny dostęp chociażby do technologii mobilnych sprawia, że przekazywanie informacji jest możliwe na niespotykaną dotąd skalę. Tym większym wyzwaniem staje się zarządzanie informacją. Przechodzi ono transformację: od strategicznego zarządzania, poprzez zarządzanie wiedzą, aż po zarządzanie informacją i źródłami tej informacji. Nowoczesne technologie dają bardzo wiele możliwości gromadzenia tej informacji. A technologie te staną się źródłami informacji także w transporcie publicznym już w najbliższej przyszłości.

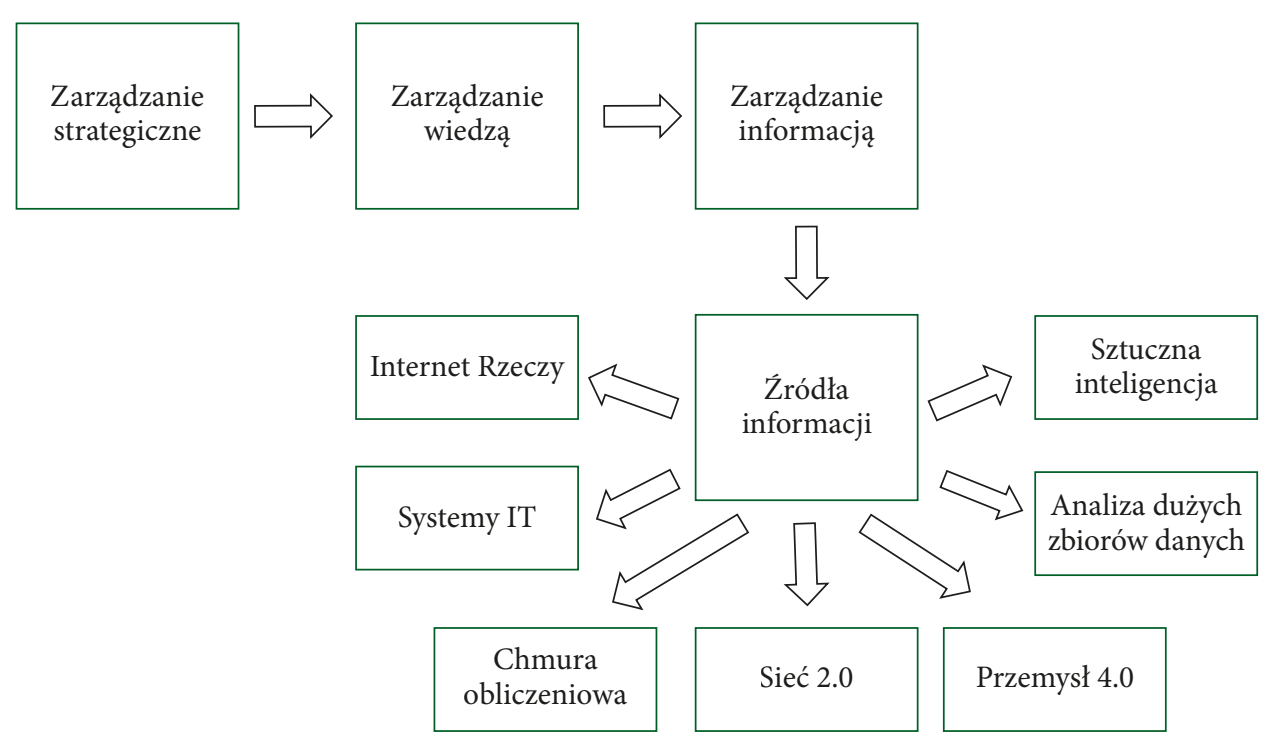

Rysunek 4.15. Od zarządzania strategicznego do zarządzania informacją

Źródło: (Jurczak, 2020, s. 38). 
Listę potencjalnie najistotniejszych (także dla transportu publicznego) źródeł informacji przedstawiono na rysunku 4.15. Będą one wyznaczać kierunki rozwoju systemów informatycznych dla transportu publicznego, jak i szerzej - kierunki zarządzania wiedzą i informacją w systemach transportu publicznego. Jako istotne należy tu wskazać przede wszystkim rozwiązania związane z szeroko rozumianą automatyzacją procesów i zadań - zarówno pochodne „przemysłu 4.0” określającego automatyzację i digitalizację procesów produkcyjnych, jak i nowe narzędzie dostarczania danych chociażby z licznych czujników składających się na systemy „internetu rzeczy” (Internet of Things). To w kontekście chociażby pojazdów. Z kolei w perspektywie samych systemów informatycznych należy zwrócić uwagę na wszelkie elementy związane ze sztuczną inteligencją i gromadzeniem danych oraz zarządzaniem danymi.

\subsection{Systemy mobilności indywidualnej jako źródło innowacji $w$ transporcie publicznym}

Zgodnie z przedstawionymi w rozdziale 1 teoriami dotyczącymi innowacji za innowację można uznać wszelkie działania związane zarówno $\mathrm{z}$ wdrażaniem nowych technologii, jak i inną organizacją procesów. Tym samym za innowacje można uznać także systemy związane z nowymi formami mobilności miejskiej,

Ustawa Prawo o ruchu drogowym (Ustawa PoRD, 2021) wprowadza dwie definicje istotne z punktu pojazdów indywidualnych: „Urządzenie transportu osobistego” to „pojazd napędzany elektrycznie, z wyłączeniem hulajnogi elektrycznej, bez siedzenia i pedałów, konstrukcyjnie przeznaczony do poruszania się wyłącznie przez kierującego znajdującego się na tym pojeździe" (s. 9). Druga definicja dotyczy hulajnogi elektrycznej, określonej jako „pojazd napędzany elektrycznie, dwuosiowy, z kierownicą, bez siedzenia i pedałów, konstrukcyjnie przeznaczony do poruszania się wyłącznie przez kierującego znajdującego się na tym pojeździe" (s. 9). Nowelizacja ustawy PoRD z 2021 roku obok dwóch powyższych definicji wprowadza także definicję „urządzenia wspomagającego ruchu”, którym jest „urządzenie lub sprzęt sportowo-rekreacyjny, przeznaczone do poruszania się osoby w pozycji stojącej, napędzane siłą mięśni” (s. 8).

Wprowadzenie nowych zapisów to odpowiedź na zmiany w mobilności miejskiej. Powszechność pojazdów typu hulajnoga sprawiła, że konieczne stało się uregulowanie zasad przemieszczania się nimi. Problem stał się bardzo aktualny z uwagi na coraz częstsze kolizje z udziałem uczestników ruchu drogowego poruszających się rozmaitymi pojazdami „osobistymi”. Jako innowację można tu uznać zarówno pojawienie się na rynku nowych pojazdów, jak i wprowadzenie do miast całych systemów zarządzania nimi. Szeroka dostępność pojazdów ułatwiających sprawne przemieszczanie się w miejskiej przestrzeni oznacza pojawienie się w niej tak hulajnóg elektrycznych, jak i pojazdów typu Segway. Same jednoślady występują w wielu 
wariantach - w ruchu są pojazdy indywidualnie użytkowane, hulajnogi czy rowery udostępniane przez operatorów prywatnych oraz rowery miejskie i elektryczne. $\mathrm{Za}$ innowację miejską można także uznać systemy typu car sharing - i choć dziś wszyscy przyzwyczaili się już do ich obecności na ulicach polskich miast, kilka lat temu uchodziły za rozwiązanie nowe i innowacyjne.

Rolą samorządów miejskich jest nie tylko tworzenie systemów regularnie kursującej komunikacji publicznej, ale przede wszystkim szeroko rozumiane wspieranie miejskiej mobilności. A to oznacza wdrażanie także rozwiązań, które wspierają indywidualne przemieszczanie się po mieście, z wykorzystaniem zarówno UTO, jak i pojazdów prywatnych czy współdzielonych. Za miejskie innowacje można zatem uznać wszystkie te rozwiązania, które w nowoczesny sposób wspierają mobilność także w zakresie parkowania, systemów opłat i płatności, aplikacji mobilnych czy nawet nowoczesnych, innowacyjnych elementów infrastruktury przesiadkowej.

Nowe rozwiązania - infrastrukturalne, informatyczne, systemowe - wspomagają miejską mobilność. Z powodzeniem można je uznać za innowacyjne. Coraz częściej pojawiają się także rozwiązania o charakterze integracyjnym. Jako przykład posłużyć tu może aplikacja pokazująca dostępność samochodów, skuterów czy rowerów publicznych wypożyczanych na minuty. Mowa o aplikacji Takeむdrive, z której przykładowy zrzut ekranu przedstawiono na rysunku 4.16. Aplikacja ta integruje informację na temat dostępnych pojazdów, a przy samej rezerwacji odsyła do systemu zewnętrznego.

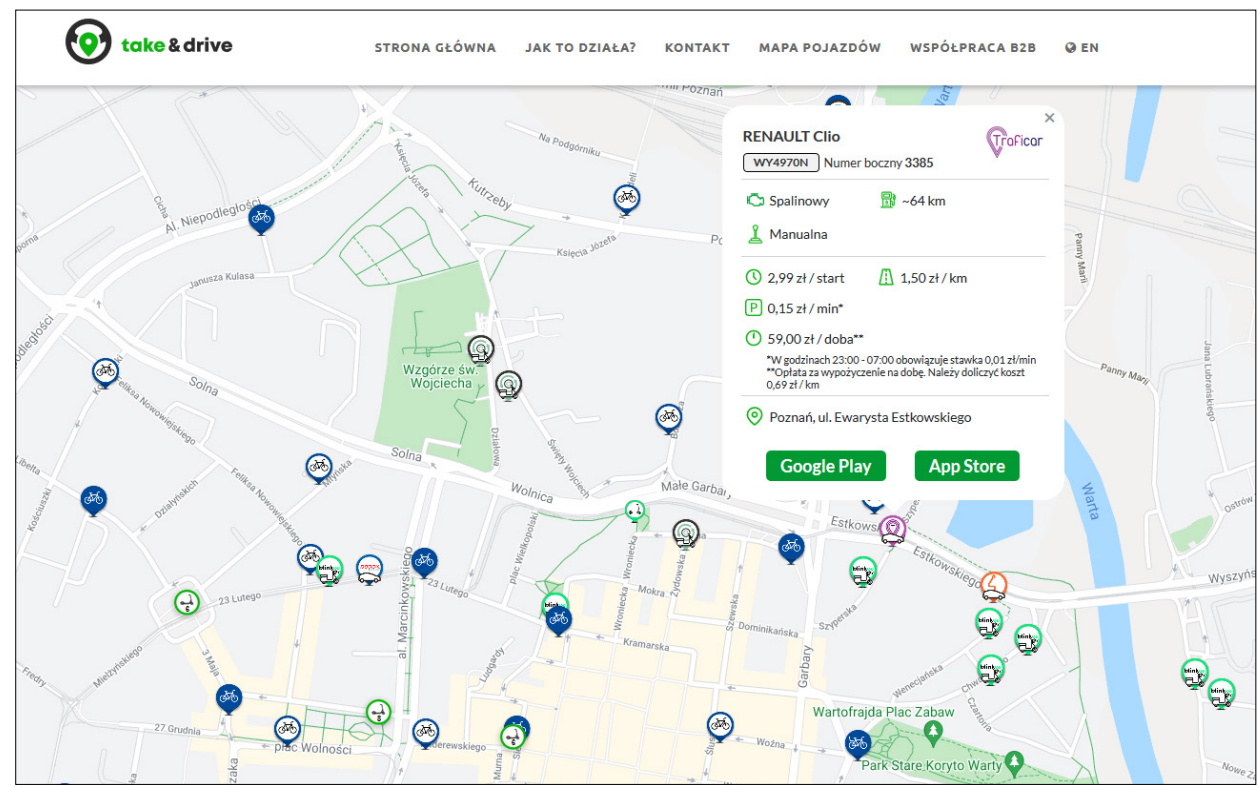

Rysunek 4.16. Aplikacja Takeひdrive - dostępność pojazdów $\mathrm{z}$ wielu systemów współdzielenia

Źródło: (Take\&drive, 2021). 
Modele mobilności „na żądanie”, dotyczącej pojazdów współdzielonych, sprawdzają się przede wszystkim w miastach. Pozwalają one rozwiązać problem blokujący rozwój wielu miast - związany z koniecznością zapewnienia mobilności. I nie chodzi o same samochody, ale o sposób ich wykorzystywania (Szymczak, 2018).

\subsection{Wybrane innowacje organizacyjne}

Zgodnie $\mathrm{z}$ wieloma definicjami za innowację można uznać także nowy sposób organizacji procesów, wcześniej niespotykany i niestosowany, na przykład w wybranym kontekście. Idąc tym tropem, nowy sposób organizacji przewozów lub organizacja procesów w sposób nowy i nietypowy również może zostać uznana za działalność o charakterze innowacyjnym. W tym miejscu wskazane zostaną dwa przykłady innowacyjnej organizacji ruchu w zakresie transportu szynowego. O ile w przypadku transportu drogowego znacznie łatwiej wprowadzić takie rozwiązania, o tyle w przypadku transportu szynowego $\mathrm{z}$ wiadomych względów należy je uznać za rozwiązania o charakterze innowacyjnym.

Kolejny przykład to pierwszy w Poznaniu (i prawdopodobnie pierwszy w Polsce) podwójny rozjazd nakładkowy $\mathrm{z}$ torem tymczasowym umożliwiającym poruszanie się tramwajów w kierunku dotychczas nieobsługiwanym. Rozjazdy nakładkowe są coraz częściej stosowane w polskich przedsiębiorstwach komunikacyjnych. Zwykle są montowane, aby umożliwić przejazd $\mathrm{z}$ toru na tor sąsiedni na tymczasowych, ślepych końcówkach tramwajowych. Stanowią alternatywę dla stosowanych wcześniej rozjazdów zabudowanych w torowisku w sposób klasyczny. Dzięki ułożeniu rozjazdu nakładkowego na istniejącym torowisku czas jego montażu znacznie się skraca. Sporadycznie takie rozjazdy (parami) są także wykorzystywane do utworzenia odcinka jednotorowego, który pozwala utrzymać komunikację tramwajową $\mathrm{w}$ trakcie remontu po jednym torze, ale dwukierunkowo - taki przejazd jest zwykle zabezpieczany także sygnalizacją świetlną.

W Poznaniu u zbiegu ul. Wrocławskiej, Strzeleckiej, Podgórnej i Św. Marcin zastosowano dwa rozjazdy nakładkowe, które kierują tramwaje na jeden tor. Nietypowość tego rozwiązania polega na ułożeniu dodatkowo łuku torowiska tymczasowego w relacji dotychczas nieobsługiwanej - co pozwala nie tylko prowadzić ruch po jednym torze, ale zapewnia też utrzymanie komunikacji tramwajowej pomimo zamknięć torowych ulic sąsiednich. $Z$ uwagi na geometrię ulic, na których ułożono torowisko, i konieczność utrzymania odpowiedniego promienia łuku oraz nachylenia toru, możliwe było ułożenie w tym miejscu tylko jednego toru - stąd decyzja o wprowadzeniu ruchu wahadłowego. Szczegółowy układ nietypowego torowiska przedstawiono na rysunku 4.17 - kolorem szarym oznaczając stałe to- 
rowisko tramwajowe, kolorem czerwonym - obszar wyłączony z ruchu z powodu remontu, a kolorem zielonym - tymczasowe torowisko i rozjazdy nakładkowe. Przejazd tramwaju tymże odcinkiem przedstawiono na rysunku 4.18.

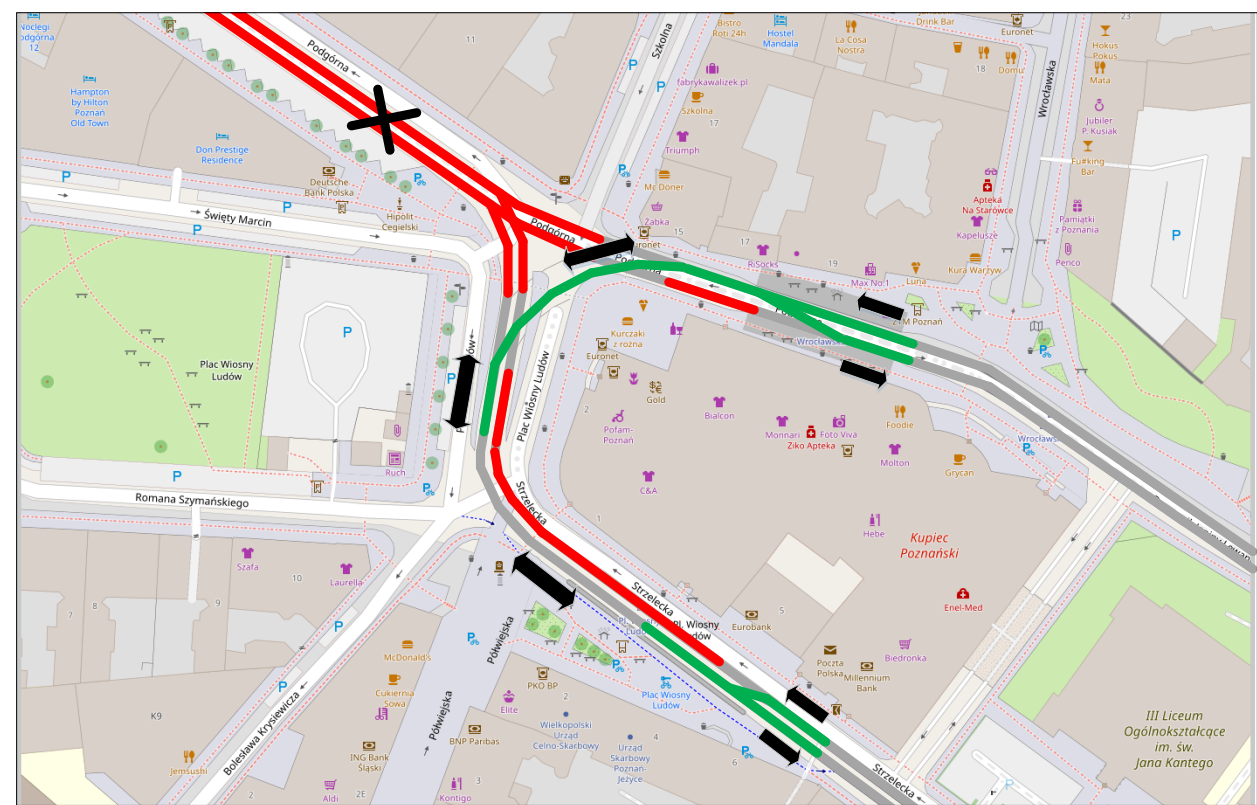

\section{Rysunek 4.17. Schemat układu torowego dla torowiska tymczasowego}

Źródło: opracowanie własne, podkład mapowy: (Openstreetmap.org, 2021).

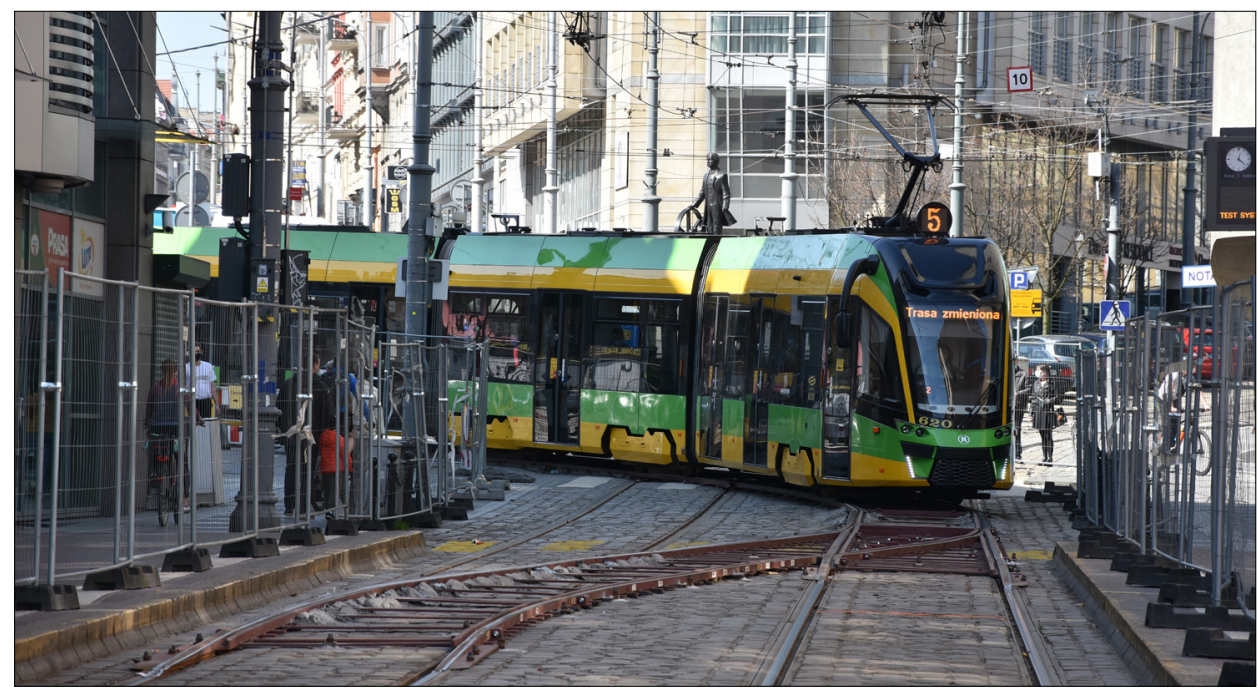

Rysunek 4.18. Przejazd tramwaju łukiem torowiska tymczasowego 
Modernizacja torowiska na ul. Podgórnej to część „Programu Centrum” - projektu kompleksowej modernizacji torowisk tramwajowych w centrum Poznania. Tymczasowe torowisko tramwajowe uruchomiono 10 kwietnia 2021 roku (MPK Poznań, 2021a). Zastosowane rozwiązanie należy uznać za innowację z kilku powodów. Po raz pierwszy wykorzystano torowisko tymczasowe do utrzymania nie tylko przejezdności i ruchu tramwajowego, ale i stworzenia nowej relacji (łuk torowiska). Wykorzystano także podwójny rozjazd nakładkowy - również używany dotychczas głównie do innych celów (zapewnienia zmiany kierunku jazdy). Dodatkowo zabudowano (pierwszy raz w Poznaniu) dedykowaną sygnalizację świetlną ze sterowaniem radiowym - każdy tramwaj podjeżdżający do odcinka jednotorowego zgłasza do sterownika potrzebę wyświetlenia sygnału na semaforze i otrzymuje zgodę na wjazd na odcinek jednotorowy.

Podobne rozwiązanie można było zaobserwować w Ostrawie, kiedy to w trakcie budowy wiaduktu na ul. Vyskovickiej torowisko tramwajowe ułożono na tymczasowej podbudowie, w miejscu jednego z pasów dla samochodów - co pokazano na rysunku 4.19.

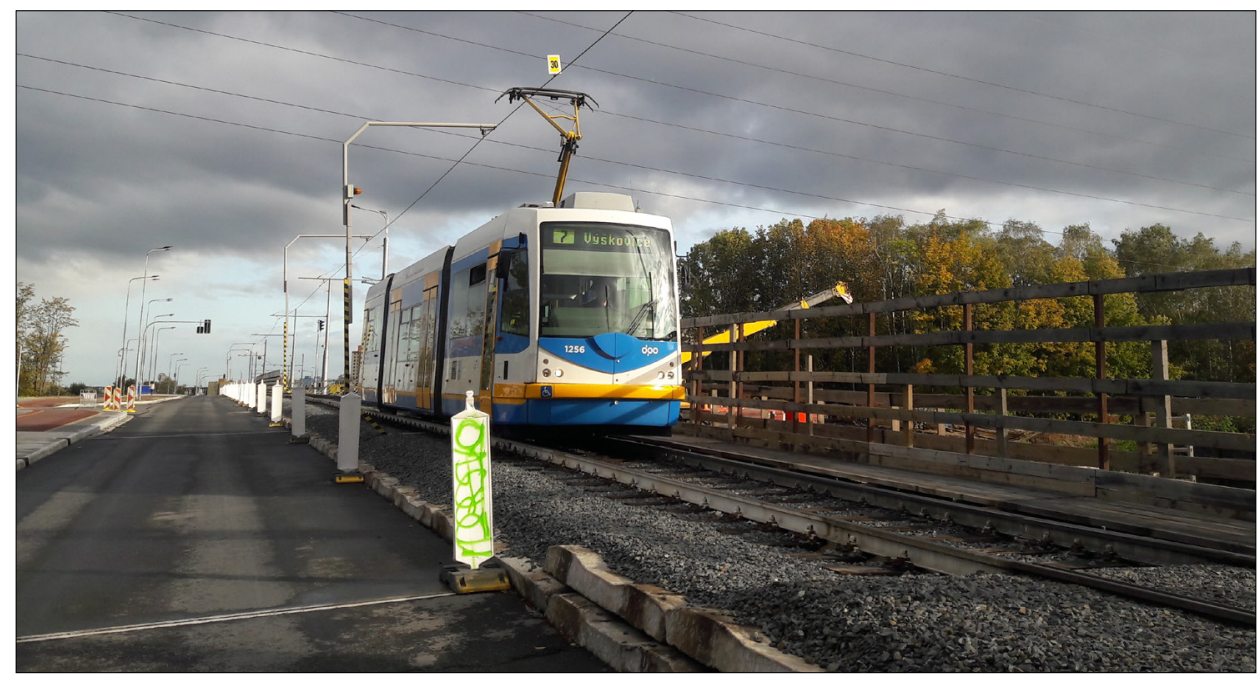

Rysunek 4.19. Przejazd tramwaju torowiskiem tymczasowym w Ostrawie

Takie innowacje organizacyjne i procesowe pozwalają na utrzymanie ruchu tramwajowego niezależnie od prowadzonych prac infrastrukturalnych.

Jeżeli uznamy za innowację także sposób organizacji transportu i gromadzenie wiedzy na temat sposobu jego funkcjonowania, to za innowacje o charakterze organizacyjnym należy uznać również powołanie do życia niezależnego ciała doradczego, wspomagającego organizatora transportu publicznego.

W 2018 roku przy Zarządzie Transportu Miejskiego w Warszawie powstała Rada Warszawskiego Transportu Publicznego - powołana do życia jako miejsce 
wymiany opinii, zbierania sugestii czy informacji od przedstawicieli różnych środowisk. ZTM jako organizator transportu publicznego w Warszawie i gminach ościennych chciał stworzyć mechanizm oceny stosowanych rozwiązań, a także zebrać opinie różnych środowisk uczestniczących w życiu miasta. Członkami Rady zostali przedstawiciele pięciu grup: społecznej (między innymi organizacje pozarządowe), ekologicznej (organizacje zajmujące się zrównoważonym rozwojem), biznesowej (przedsiębiorcy, deweloperzy, ale także przedstawiciele operatorów), samorządowej (przedstawiciele gmin, urzędy i rady miasta, ZTM) i naukowej (eksperci z różnych dziedzin nauki). Do połowy 2021 roku Rada WTP wypracowała 11 rekomendacji dotyczących różnych obszarów funkcjonowania transportu publicznego. Rekomendacje te dotyczą całego szerokiego spektrum funkcjonowania transportu publicznego, zarówno w ujęciu miejskim, jak i aglomeracyjnym, ale także obszarów pośrednio związanych $\mathrm{z}$ innymi formami mobilności miejskiej (ekologia, bezpieczeństwo na drogach, przewóz rowerów czy UTO, pandemia) (Warszawski Transport Publiczny, 2021).

9 grudnia 2020 roku zainaugurowano pierwsze spotkanie Poznańskiej Rady Transportu Aglomeracyjnego - drugiego takiego gremium w kraju. W skład PRTA weszli reprezentanci różnych środowisk: przedstawiciele samorządu, organizacji zrzeszających przedsiębiorców, organizatora i operatorów transportu, środowisk naukowych, organizacji pozarządowych, ekologicznych czy ruchów miejskich i spółdzielni mieszkaniowych. Ideą było stworzenie możliwie szerokiego zespołu, który mógłby być platformą wymiany wiedzy i doświadczeń, ale także pomysłów i poglądów na temat różnych aspektów funkcjonowania transportu publicznego. Powstanie rady zainicjował Zarząd Transportu Miejskiego w Poznaniu. Łącznie PRTA liczy ponad 20 członków, a efektem jej działania są rekomendacje zmian i usprawnień (poznan.pl, 2020). PRTA zajmuje się szerokim zakresem tematycznym, $z$ założenia dotyczy to między innymi obszarów organizacyjnych, przewozowych, handlowych, taryfowych czy infrastrukturalnych. Posiedzenia Rady prowadzi moderator zapewniający bezstronność i obiektywizm. W trakcie pierwszych spotkań PRTA wypracowała już pierwsze rekomendacje tematów: komfortu termicznego i oświetleniowego w pojazdach transportu publicznego (rekomendacja nr 1), określenia katalogu obowiązkowego i fakultatywnego wyposażenia węzłów przesiadkowych w aglomeracji poznańskiej (rekomendacja nr 2) i rozszerzenia funkcjonalności systemu PEKA o komunikaty o opóźnieniach skorelowanych ze sobą środków transportu (rekomendacja nr 3). Należy zauważyć, że opinie w wielu sprawach dotyczących rozwiązań transportowych nie zawsze są jednomyślne, a zadaniem Rady jest zbieranie ocen i propozycji oraz wypracowanie konsensusu (Zarząd Transportu Miejskiego w Poznaniu, 2021).

Powyżej wskazano dwa przykłady niezależnych zespołów eksperckich wpływających na kształt transportu publicznego. Rolą takich zespołów doradczych jest między innymi wywołanie dyskusji na tematy, które są istotne z punktu widzenia pasażera 
transportu publicznego, a z racji konieczności zaangażowania wielu środowisk nie zawsze mogą być skutecznie rozwiązywane na poziomie wyłącznie samorządu, organizatora transportu czy operatora. Możliwość wypracowania rekomendacji na wyższym poziomie ogólności pozwala identyfikować obszary wymagające usprawnień, a następnie, wykorzystując między innymi zebrane dobre praktyki, doświadczenia czy pomysły, tworzyć konkretne wytyczne. Dodatkowym efektem jest tu stworzenie mechanizmów wymiany wiedzy i doświadczeń - z korzyścią także dla uczestników spotkań tych zespołów.

\subsection{Innowacyjne środki transportu}

Jako innowację należy także potraktować nowe, niewykorzystane wcześniej środki transportu. Taką innowacją w skali kraju będzie rozwiązanie zaproponowane przez Politechnikę Warszawską. „Polinka” to nazwa kolejki linowej uruchomionej w 2013 roku z myślą o studentach, którzy przemieszczali się pomiędzy głównym kampusem uczelni a kampusem przy ul. Na Grobli - kolejka liniowa znacznie skróciła tę drogę. Wagonik kolejki pokonuje trasę ok. 380 metrów, w szczytowym momencie znajdując się około 7 metrów nad lustrem rzeki Odry. Przejazd jest bezpłatny dla studentów, doktorantów i pracowników Politechniki Wrocławskiej, dla innych zainteresowanych pasażerów dostępne są bilety jednorazowe. Polinka kursuje zarówno w dni robocze, jak i w soboty czy niedziele - częściej w trakcie roku akademickiego. Wagoniki pokonujące trasę „Polinki” przedstawiono na rysunku 4.20 (visitwroclaw.eu, 2021).

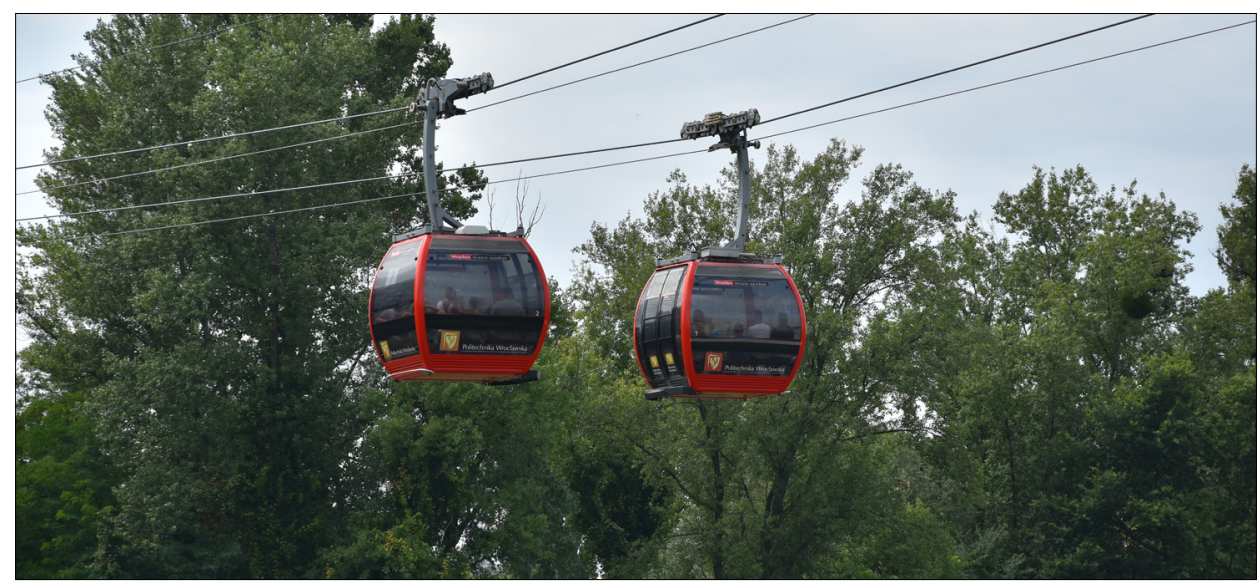

Rysunek 4.20. Kolejka linowa „Polinka” we Wrocławiu 
Podobnie za rozwiązania o charakterze innowacyjnym należałoby uznać Warszawską Kolej Dojazdową (jako jedyną taką linię kolejową w Polsce, do niedawna funkcjonującą dodatkowo z wykorzystaniem "tramwajowego" napięcia sieci trakcyjnej) czy chorzowską kolejkę linową - która choć nie stanowi elementu systemu transportu publicznego, jest jedyną tego typu kolejką w kraju. 


\section{INNOWACJE I ICH WPŁYW NA RYNEK TRANSPORTU PUBLICZNEGO}

\subsection{Wdrażanie innowacji jako element realizacji celu publicznego}

Transport publiczny ma charakter usługi publicznej ze wszystkimi tego konsekwencjami - tak jak wskazano $\mathrm{z}$ rozdziale 2.4. Innowacje $\mathrm{w}$ transporcie publicznym mogą odgrywać jeszcze jedną bardzo ważną rolę - stać się źródłem łatwiejszego dostępu do usług publicznych dla osób z rozmaitymi dysfunkcjami. „Transport pasażerski, nie tylko miejski, powinien na równych prawach uwzględniać potrzeby całej populacji, a zwłaszcza potrzeby osób o ograniczonej mobilności. W ich przypadku bowiem ma to istotny wpływ na wszystkie aspekty życia - od edukacji, dostępu do dóbr kultury, rozrywki, sportu, miejsca pracy, rodziny, po nawiązywanie zwykłych kontaktów międzyludzkich" (Pędziwiatr i Kasińska, 2017, s. 89). Sam transport publiczny musi dziś podążać za demografią, zmianami o charakterze społecznym czy rozlewaniem się miast.

Przez lata dostęp do komunikacji publicznej był utrudniony między innymi dla osób, które mają problemy z poruszaniem się. Pojazdy wysokopodłogowe w praktyce były nieosiągalne dla osób poruszających się na przykład na wózkach inwalidzkich, a ich dostępność dla osób poruszających się samodzielnie, ale z problemami (chociażby o kulach) była mocno ograniczona. W drugiej połowie lat 90. XX wieku, wraz z upowszechnianiem się najpierw autobusów, a później tramwajów niskopodłogowych, dostępność do komunikacji publicznej znacznie wzrosła. Dotyczy to także rodzin z dziećmi, dla których również innowacyjne (wówczas) pojazdy niskopodłogowe stanowiły ważną zmianę. Ułatwienia dostępu do komunikacji publicznej (a wraz z nim zwiększenie mobilności i dostęp do innych usług) to nie tylko pojazdy niskopodłogowe. To także chociażby systemy dużych tablic informacyjnych czy zapowiedzi głosowe ułatwiające przemieszczenie się osobom niewidomym i słabo widzącym, czy też nowe napędy w pojazdach zapewniające bezpieczniejsze, płynne przemieszczanie się w ruchu miejskim.

Należy zauważyć, że w wielu sytuacjach innowacje pozwalają poprawić standard usługi czy jej efektywność ekonomiczną. Można tu wskazać kilka przykładów. Omawiane szczegółowo w rozdziale 4 napędy alternatywne w pojazdach komunikacji publicznej to odpowiedź na potrzebę poprawy jakości życia w mieście i ogranicze- 
nie zanieczyszczeń. Minione lata upłynęły pod znakiem szerokiego finansowania inwestycji w tabor komunikacji publicznej ze środków zewnętrznych. To pozwoliło gwałtownie zwiększyć liczbę autobusów zasilanych gazem, hybrydowych czy elektrycznych, zepchnęło jednak na dalszy plan dyskusję o ekonomicznych aspektach tego typu innowacji. To dyskusja, która czeka kolejne miasta w najbliższych latach wraz ze starzeniem się innowacyjnych pojazdów i pojawieniem się nowych napędów (na przykład autobusów zasilanych ogniwami paliwowymi i wykorzystujących jako paliwo wodór) wciąż jest aktualny temat kosztów zakupu pojazdów i ich utrzymania (zgodnie z TCO czy inną metodologią).

Jako przykład innowacji wspierającej realizację celu publicznego posłużyć mogą także znaczniki Totupoint zamontowane między innymi na nowej trasie tramwajowej w Poznaniu. Tramwaje z pasażerami kursują tu od 21 sierpnia 2021 roku, a wśród licznych innowacji technicznych jest system wspierający niewidomych i niedowidzących w bezpiecznym poruszaniu się. Na nowym odcinku trasy tramwajowej znajduje się 26 znaczników - niewielkich kostek montowanych na przystankach, współpracujących $\mathrm{z}$ aplikacją na smartfony. Po zbliżeniu się do znacznika, pasażer otrzymuje komunikat głosowy. Aplikacja pozwala poznać topografię przystanku i okolicznej przestrzeni. Totupoint działa w ponad 800 miejscach w Polsce, w samym Poznaniu jest ich prawie 200. A trasa tramwajowa na Naramowice to pierwsza trasa tramwajowa w naszym kraju, która ma być na całej długości pokryta znacznikami (Fundacja MIR, 2021).

Kolejnym przykładem mogą być inwestycje w zazielenienie infrastruktury transportu miejskiego. Na transport publiczny nie można patrzeć wyłącznie przez pryzmat efektywności ekonomicznej. Systemy transportu publicznego stanowią ważny element struktury miasta i decydują o jakości życia w mieście. Dotyczy to zarówno samych pojazdów, jak i tworzonej infrastruktury. W polskich miastach wiele się mówi w ostatnich latach o tzw. małej retencji - tworzeniu rozwiązań służących gromadzeniu wody w okolicy, co ma pozwalać na zagospodarowanie wody w mieście, zmniejszanie ryzyka powodzi i podtopień czy zmniejszanie temperatury w sezonie letnim. Jednym z elementów małej retencji jest zadrzewianie (i tworzenie terenów zielonych w innej formie). Transport publiczny intensywnie korzysta z miejskiej przestrzeni - chociażby poprzez infrastrukturę liniową czy punktową. Tym samym za cenne należy uznać wszystkie inicjatywy zwiększające udział powierzchni biologicznie czynnych. W wielu polskich miastach powstają obecnie „zielone” torowiska - przestrzeń wewnątrz i w bezpośrednim sąsiedztwie toru jest obsadzana trawą lub inną roślinnością. To jednak nie jedyne sposoby na „zazielenienie” miejskiej infrastruktury.

$\mathrm{Na}$ warszawskich pętlach tramwajowych posadzono 7600 letnich kwiatów begonie zostały umieszczone w piętrowych kwietnikach. Rośliny (o wysokości do $70 \mathrm{~cm}$ ) pojawily się w siedmiu lokalizacjach, wraz z towarzyszącymi im bylinami i trawami. Sezonowe nasadzenia kwiatów to część prac, których Zarząd Oczyszczania Miasta podjął się na 57 pętlach komunikacji publicznej. Rośliny dobierane są tak, by sprostać trudnym wymaganiom miejskiej specyfiki - odpowiednio odporne 
na temperaturę, słońce, wiatr czy spaliny (Czubiński, 2021). Z kolei w Poznaniu, na dachach wiat przystanków tramwajowych i autobusowych, zaczął się pojawiać rozchodnik - niewielka roślina występująca zwykle na terenach skalistych lub piaszczystych. Roślina łatwo się rozrasta, ma płytki system korzeniowy i jest odporna na warunki pogodowe - jest zatem idealna, by rosnąć na płaskim dachu wiaty przystankowej. Pierwsze osiem wiat pojawiło się w 2019 roku, kolejne sukcesywnie przybywają na poznańskich ulicach. „Ekowiaty” to część większego projektu wymiany wiat na przystankach komunikacji publicznej nadzorowanego przez firmę City Marketing - spółkę Grupy MTP (Międzynarodowych Targów Poznańskich) zajmującą się reklamą outdoorową (epoznan.pl, 2020).

Podstawowym źródłem przychodów w systemie transportu publicznego pozostają ceny biletów. Są one pochodną jakości realizowanej usługi transportowej. Im wyższy standard, tym wyższe koszty... i wyższe ceny biletów. To prowadzi do ciekawego zjawiska, które może być przedmiotem analiz w przyszłości: Czy pasażerowie komunikacji publicznej są gotowi do ponoszenia na zasadzie solidarności kosztów innowacji? Czy będą gotowi korzystać z usługi innowacyjnej, ale oferowanej w wyższej cenie? Jak duża jest wrażliwość na zmiany cen w transporcie publicznym związane z pojawieniem się rozwiązań innowacyjnych i wdrażaniem nowych standardów? Na te pytania nie ma dziś jednoznacznej odpowiedzi: w zależności od grupy użytkowników, specyfiki konkretnego systemu transportowego, jego innowacyjności czy ogólnie poziomu zamożności użytkowników systemu odpowiedź na te pytania może być bardzo różna. Rozwój systemów transportu publicznego zawsze niestety nakazuje postawić pytanie, kto rozwój ten będzie finansował.

Cena usługi transportowej jest nierozerwalnie związana $\mathrm{z}$ samą usługą jako produktem działalności transportowej - z jej użytecznością oraz etapem cyklu życia produktu. Usługa transportowa, podobnie jak inne produkty, podlega oddziaływaniu cyklu życia produktu, czyli jego zmiennej, rynkowej atrakcyjności. Usługa transportowa jako taka nie traci generalnie swojej użyteczności, ale wraz ze sposobem świadczenia i dopasowaniem do potrzeb transportowych musi się zmieniać. W miarę upływu czasu coraz słabiej odpowiada bowiem zmieniającej się potrzebie transportowej (Tomanek, 2007).

\subsection{Wdrażanie innowacji a efektywność ekonomiczna przedsiębiorstwa}

Istnieje wiele sposobów oceny efektywności ekonomicznej i efektywności realizacji procesów. Warto wskazać w tym miejscu kilka koncepcji, które znajdują zastosowanie $\mathrm{w}$ logistyce i transporcie, mogą być zatem $\mathrm{z}$ powodzeniem wykorzystane 
w ocenie efektywności realizacji usług transportu publicznego. Tak jest chociażby z koncepcją rachunku kosztów w logistyce. Informacje dotyczące kosztu wdrażania innowacji są nieprecyzyjne. Innowacja bowiem niesie ze sobą pierwiastek nieprzewidywalności - zarówno technicznej, organizacyjnej, jak i kosztowej.

Zasadniczo prowadzone analizy powinny się opierać na informacjach, które mają charakter wiarygodny i rzeczywisty, odpowiednio urealniony między innymi analizami systemowymi. W ujęciu zarządczym można wydzielić rachunek systematyczny i problemowy - ten pierwszy w celu pomiaru kosztów, ich badania i kwantyfikacji, a także prezentacji kosztowych aspektów zdarzeń i przedsięwzięć, ten drugi - aby wesprzeć realizację procesu decyzyjnego oraz określać wzorce (Blaik, 2017).

Warto tu wskazać także na narzędzia i metody służące pomiarowi kosztów, chociażby na metody LCC czy TCO.

Rachunek kosztu cyklu życia - LCC (life cycle cost) to analiza ekonomiczna biorąca pod uwagę koszty ponoszone w trakcie cyklu życia produktu, usługi, robót budowlanych. Oznacza to między innymi koszty związane z nabyciem, użytkowaniem (na przykład zużycie energii), utrzymaniem, wycofaniem $z$ eksploatacji (na przykład koszty recyclingu), ale także koszty przypisywane ekologicznym efektom zewnętrznym związane z cyklem życia produktu. Idea wykorzystania LCC (na przykład przy realizacji zamówień publicznych) jest taka, by nie napotykać „syndromu góry lodowej". W praktyce bowiem koszt zakupu jest często wierzchołkiem góry lodowej w całym cyklu życia produktu, a znakomitą większość kosztów stanowią niewidoczne na pierwszy rzut oka koszty związane z posiadaniem, co skłania do zwrócenia uwagi nie tylko na cenę zakupu, ale i parametry: niezawodność, funkcjonalność, energooszczędność, łatwość obsługi w całym cyklu życia (Bogusz, 2017).

Analiza kosztów w całym cyklu życia inwestycji nosi nazwę analizy LCCA (lice cycle cost analysis). Jej celem jest określenie ekonomicznej efektywności inwestycji z uwzględnieniem kosztów związanych z przyjętymiu rozwiązaniami projektowymi na każdym etapie procesu inwestycyjnego (Dziadosz, 2015). Wskazana autorka odnosi się co prawda do konkretnego przykładu (obiektów budowlanych), jednak taka analiza w praktyce może być zastosowana do inwestycji dowolnego typu. A zakładając, że innowacja to inwestycja - daje to potencjał zastosowania modelu LCC i analizy LCCA przy projektach wdrażania innowacji dowolnego niemal typu.

Podobne podejście jest konieczne w analizie kosztów metodą TCO - total cost of ownership, zgodnie z którą analizowany jest całkowity koszt posiadania danego zasobu, a nie tylko jego zakupu.

W kontekście oceny innowacyjności usług transportu publicznego warto przytoczyć jeszcze kilka zapisów ustawy o publicznym transporcie zbiorowym, bowiem ustawodawca przewiduje finansowanie realizowanych usług. Zgodnie z art. 50 Ustawy, „Finansowanie przewozów o charakterze użyteczności publicznej może polegać w szczególności na: 1) pobieraniu przez operatora lub organizatora opłat w związku 
$\mathrm{z}$ realizacją usług świadczonych $\mathrm{w}$ zakresie publicznego transportu zbiorowego, lub 2) przekazaniu operatorowi rekompensaty" (Ustawa, 2020, s. 24). Rekompensata ta może być wypłacona z tytułu: „utraconych przychodów w związku ze stosowaniem ustawowych uprawnień do ulgowych przejazdów w publicznym transporcie zbiorowym”, „utraconych przychodów w związku ze stosowaniem uprawnień do ulgowych przejazdów w publicznym transporcie zbiorowym ustanowionych na obszarze właściwości danego organizatora, o ile zostały ustanowione” lub „poniesionych kosztów w związku ze świadczeniem przez operatora usług w zakresie publicznego transportu zbiorowego” (Ustawa, 2020, s. 24). Tak ogólny zapis dotyczący „poniesionych kosztów" w praktyce pozwala dowolnie wesprzeć operatora finansowo, na przykład w celu motywacji do wdrażania innowacji. Oczywiście takie zapisy wymagają pełnej współpracy obu stron - organizatora i operatora. A w praktyce organizator może w ten sposób „akceptować” realizację innowacji podnoszących koszty funkcjonowania transportu publicznego - podnoszących jakość systemu transportowego i jakość życia w mieście kosztem wyższych kosztów funkcjonowania systemu transportowego.

\subsection{Innowacja a rynek transportu publicznego}

Ciągły rozwój potrzeb w połączeniu z nowymi wymaganiami w zakresie zarówno komfortu podróży, jak i standardów technicznych pojazdów sprawia, że skraca się cykl życia środków transportu. Pojazdy, które z technicznego punktu widzenia mogłyby jeszcze być eksploatowane, zostają zastąpione nowszymi, wygodniejszymi, o niższej emisji zanieczyszczeń.

Ważnym trendem na rynku autobusowym stała się elektromobilność. Zmiana sposobu zasilania pojazdów ma fundamentalne znaczenie z punktu widzenia ochrony środowiska, ale w praktyce wcale nie musi oznaczać gwałtownego poprawienia warunków komfortu dla pasażerów. Należy zauważyć, że współczesne autobusy miejskie zapewniają wysoki komfort podróżowania, także w zakresie poziomu hałasu czy emisji drgań. Przejście od napędu spalinowego do napędu elektrycznego pozwala podnieść komfort jazdy, nie stanowi jednak rewolucji, lecz ewolucję w tym zakresie. Oczywiście należy mieć tu na uwadze, że nowy napęd to przede wszystkim rewolucja pod względem technicznym. A wyższy komfort jazdy, na przykład poprzez obniżenie poziomu hałasu, udaje się osiągnąć niejako przy okazji.

Zakupy pojazdów z napędem alternatywnym są dziś coraz częściej standardem i koniecznością. Deklaracje w tym zakresie składają wszyscy przewoźnicy miejscy. Prezydent Jaworzna deklaruje, że miasto dąży do udziału autobusów elektrycznych w przewozach w $80 \%$. MZA Warszawa deklaruje, że do 2020 roku będzie kupował 
wyłącznie pojazdy elektryczne i gazowe, z kolei przedstawiciele przewoźnika z Pragi zwracają uwagę, że konieczna jest tu różnorodność, chociażby na wypadek sytuacji nieprzewidzianych (Dybalski, 2018b). Bez wątpienia wymiana pojazdów na nisko- lub zeroemisyjne stała się ważnym trendem, bardzo często służącym „przy okazji” odmłodzeniu floty i zakupowi pojazdów o wyższym poziomie wyposażenia wpływającego na komfort jazdy.

Odnowa floty to ważny problem w kontekście możliwości finansowych budżetu. Jak pokazuje przykład Gdańska, w polskich miastach wymiana taboru może przebiegać dwuetapowo. Samorządy kupują nowe pojazdy, równolegle wspomagając się zakupami używanego taboru z krajów zachodnich. Taki trend daje możliwość szybszego odmładzania floty. Przykładowo dzięki zakupowi w 2018 roku używanych autobusów miejskich z Berlina udało się wycofać z gdańskich ulic najstarsze autobusy, pochodzące z 1994 roku. Spółka Gdańskie Autobusy i Tramwaje za cenę czterech nowych pojazdów kupiła czternaście autobusów Mercedes O530 Citaro pochodzących z 2009 roku (Dybalski, 2018a). I choć oczywiście można rozpocząć dyskusję o polityce taborowej przewoźnika ze względu na ograniczone możliwości budżetowe i wyraźną różnicę wieku w stosunku do pojazdów wycofywanych, taka decyzja pozwoliła na wyraźne odmłodzenie części floty. Równolegle w Gdańsku regularnie kupowane są pojazdy nowe. W 2018 roku spółka poinformowała, że planuje zamówić (w formie dzierżawy) flotę 48 nowych autobusów (Gdańskie Autobusy i Tramwaje, 2018a). W 2018 roku dokonano zakupu 46 autobusów niskopodłogowych Mercedes Citaro. Wśród elementów wyposażenia tych pojazdów, składających się na komfort podróżowania, znalazły się między innymi klimatyzacja, monitoring, system głosowego zapowiadania przystanków, ładowarki USB, a w autobusach w wersji przegubowej także wieszaki rowerowe (Gdańskie Autobusy i Tramwaje, 2018b). W wyniku tych dwóch zamówień łącznie do ruchu w latach 2019-2020 wprowadzono 94 nowe autobusy marki Mercedes.

Życie biegnie coraz szybciej. Konsument, bombardowany informacją ze wszystkich kierunków, ma dziś przed sobą trudne zadanie. Musi się odnaleźć w gąszczu informacji i wyłowić te najcenniejsze. Rosną oczekiwania wobec komunikacji publicznej. Klient oczekuje nie tylko szczegółowych rozkładów jazdy, ale też informacji dynamicznej, potwierdzającej faktyczny podjazd pojazdu na przystanek. Przyszłość to informacja dynamiczna uwzględniająca także możliwości przesiadek - tak by zapewnić maksymalny komfort i efektywność podróżowania publicznym transportem zbiorowym. Efektywność podróżowania jest tu rozumiana między innymi jako ocena sposobu jego funkcjonowania. „Efektywność systemu transportu publicznego odnosi się do tego, jak dobrze system osiąga swoje założone cele. Pomiar efektywności jest niezwykle istotny, ponieważ dostarcza informacji o tym, jak efektywnie działa system, a to skutkuje we wcześniejszym diagnozowaniu problemów i znalezieniu możliwych rozwiązań" (Rymarz, Stokłosa i Niewczas, 2014). 


\subsection{Innowacje a rynek użytkowników transportu publicznego}

Innowacyjność przedsiębiorstw komunikacji publicznej nie pozostaje bez wpływu na postrzeganie usług przez użytkowników. Jak wskazano w rozdziale 3.4, innowacje korzystnie wpływają na satysfakcję użytkowników korzystających z usług transportu publicznego, zwiększając poziom zadowolenia.

Zasadniczo wskazane w rozdziale 4 przykłady innowacji można podzielić na te, które służą podnoszeniu sprawności funkcjonowania systemu transportowego jako całości, oraz takie, które przekładają się przede wszystkim na różne elementy związane z komfortem podróżowania. Patrząc na innowacje z tych dwóch perspektyw, można się zastanowić, na ile wpływają one korzystnie na budowanie popytu na transportu publiczny.

Podnoszenie sprawności funkcjonowania systemu transportowego pozwala na zainteresowanie nim tych grup użytkowników, dla których dotychczas był on nieatrakcyjny czasowo czy zbyt niewiarygodny. Aktualna informacja pasażerska z wykorzystaniem nowoczesnych technologii to zwiększanie atrakcyjności usług transportowych zarówno dla zabieganych, jak i młodych. Kryterium czasu pozostaje jednym $z$ istotniejszych elementów decydujących o wyborze środka transportu. Wyższa niezawodność systemu jako całości, mniejsza awaryjność czy rosnąca elastyczność - to wszystko zachęca do wyboru tej formy transportu.

Wyższy standard podróży to korzyść dla wszystkich użytkowników oraz zachęta do zmiany własnego samochodu na pojazd komunikacji publicznej dla tych, którzy wcześniej pozostawali nieprzekonani. Monitoring zwiększa poziom bezpieczeństwa (zarówno w pojazdach, jak i na przykład w obiektach infrastruktury). Odpowiednia, czytelna informacja pasażerska to ważny argument za wyborem transportu publicznego dla osób mających trudności ze wzrokiem, z kolei powszechność wykorzystania pojazdów niskopodłogowych - dla osób z trudnościami ruchowymi. Dodatkowe możliwości pojawiają się wraz z wprowadzaniem do ruchu pojazdów autonomicznych, które będą nadawać sens specjalnym liniom w obszarze o niższym zapotrzebowaniu na przewozy. To otwiera transport publiczny na nowe obszary i nowe grupy użytkowników.

Wskazane w niniejszym opracowaniu innowacje są zwykle odbierane przez użytkowników pozytywnie, jako prowadzące do poprawy funkcjonowania transportu publicznego. A najczęściej zgłaszana obawa dotyczy strony finansowej i „ryzyka” związanego ze wzrostem cen biletów za usługi świadczone na wyższym poziomie z wykorzystaniem zaawansowanych rozwiązań technicznych.

Ważnym wyzwaniem o charakterze społecznym pozostaje starzenie się społeczeństw. A innowacje (chociażby nowoczesne i bardziej dostępne pojazdy, multime- 
dialna informacja pasażerska czy infrastruktura bez barier) sprzyjają zwiększaniu dostępności transportu publicznego dla osób o ograniczonej mobilności. Spory w tym udział wskazywanych w rozdziale 4 nowych rozwiązań technicznych i technologicznych w pojazdach.

Pojazdy o napędach alternatywnych są też zwykle cichsze - obniża się poziom uciążliwości transportu publicznego dla mieszkańców. Tym samym efektywny (ekonomicznie i ekologicznie) transport miejski staje się ważnym narzędziem wsparcia dla polityki przestrzennej miasta, $w$ tym budowania otwartej, przyjaznej przestrzeni dla wszystkich jego użytkowników. To ważna korzyść dla jednostek samorządu terytorialnego, które w nowoczesnym, innowacyjnym transporcie publicznym zyskują narzędzie do budowania polityki środowiskowej miasta czy aglomeracji, a w połączeniu z nowoczesnymi narzędziami zarządzania i realizacji przewozów (także na poziomie organizacyjnym) - możliwość uczynienia transportu publicznego nie tylko źródłem korzyści środowiskowych, ale i ekonomicznych. 


\section{PODSUMOWANIE}

Stale rosnące potrzeby klientów prowadzą do zmiany standardów technicznych wdrażanych w obszarze transportu publicznego. Klienci oczekują dziś odpowiedniego poziomu komfortu i bezpieczeństwa. Zmiany te są pochodną rozwoju technicznego samych pojazdów oraz wdrażania do produkcji nowych rozwiązań technicznych. Rozwój ten przebiega zatem równolegle - nowe pojazdy korzystają $\mathrm{z}$ alternatywnych źródeł energii czy nowoczesnych materiałów, a jednocześnie oferują wyższy komfort podróżowania.

Rozwój techniczny sprawia, że pojazdy są dziś znacznie bardziej komfortowe niż jeszcze kilkanaście lat temu. Powszechność takich rozwiązań jak klimatyzacja czy monitoring znacznie zwiększyła komfort i bezpieczeństwo pojazdem komunikacji miejskiej. Przyszłość miast to zrównoważony transport publiczny. A jednym z kryteriów oceny tego transportu pozostają kryteria jakościowej oceny usług. Tym samym zaakcentowanie zmieniających się potrzeb pasażera będzie miało w rozwoju tego środka transportu coraz większe znaczenie.

Celem publikacji było stworzenie opracowania na temat wykorzystania innowacji w transporcie publicznym: w tym zebranie dostępnej wiedzy na temat innowacji realizowanych przez operatorów i organizatorów komunikacji publicznej. Problematyka dotycząca innowacji jest $\mathrm{w}$ transporcie publicznym niezwykle aktualna. A to wszystko sprawia, że jest i będzie w kolejnych latach interesującym przedmiotem badań. 


\section{BIBLIOGRAFIA}

Alstom.com. (2021a). Coradia iLint ${ }^{\mathrm{Tm}}$ - the world's 1st hydrogen powered train. Pobrane 28 sierpnia $2021 \mathrm{z}$ https://www.alstom.com/solutions/rolling-stock/coradia-ilinttm-worlds-1st-hydrogen-powered-train

Alstom.com. (2021b). Coradia iLint: Alstom presents the world's first hydrogen passenger train in Poland. Pobrane 28 sierpnia $2021 \mathrm{z}$ https://www.alstom.com/press-releases-news/2021/6/coradia-ilint-alstom-presents-worlds-first-hydrogen-passenger-train

Auvasa. (2021). Auvasa. Datos Abiertos. Pobrane 23 lipca 2021 z http://www.auvasa.es/ auv_opendata.asp

Bakici, T., Almirall, E. i Wareham, J. (2013). The role of public open innovation intermediaries in local government and the public sector. Technology Analysis \& Strategic Management, 25:3, 311-327. London: Taylor \& Francis Online. https://doi.org/10.108 0/09537325.2013.764983

Bartłomiejczyk, M. i Połom, M. (2011a). Trolejbusy z bateryjnym źródłem zasilania - doświadczenia eksploatacyjne i koncepcja liniowego zastosowania w Gdyni. Technika Transportu Szynowego, 5-6, 76-80. Radom: Instytut Naukowo-Wydawniczy „TTS” Sp. z o.o.

Bartłomiejczyk, M. i Połom, M. (2011b). Alternatywne źródła zasilania w trolejbusach - przegląd rozwiązań stosowanych w miastach europejskich, Technika Transportu Szynowego, 3, 19-24. Radom: Instytut Naukowo-Wydawniczy „TTS” Sp. z o.o.

Bartłomiejczyk, M., Goliszek, S. i Połom, M. (2016). Innowacyjne rozwiązania szansą rozwoju systemów transportu trolejbusowego na przykładzie Gdyni i Lublina. Acta Sci. Pol., Administratio Locorum, 15(4), 7-25. Olsztyn: Wydawnictwo Uniwersytetu Warmińsko-Mazurskiego.

Bednarzewska, K. E. (2016). Potrójna helisa jako model współpracy w budowaniu atrakcyjności inwestycyjnej miast, Organizacja i Zarządzanie - kwartalnik naukowy, 2, 5-20. Zabrze: Wydawnictwo Politechniki Śląskiej.

Begg, D., Fischer, S. i Dornbusch, R. (2003). Mikroekonomia. Warszawa: Polskie Wydawnictwo Ekonomiczne.

Bielawska-Pałczyńska, J. (2013). Dworzec cesarski w Poznaniu. Kronika Miasta Poznania, 4, 113-124. Poznań: Wydawnictwo Miejskie.

Biskupska, K. (2021). Konin jako pierwsze miasto w Polsce będzie użytkowało autobus wodorowy Solarisa $i$ wybuduje stację tankowania wodoru. Pobrane 4 sierpnia $2021 \mathrm{z} \mathrm{https://}$ samochody-specjalne.pl/2021/07/08/w-mzk-konin-pojawi-sie-autobus-wodorowy-solarisa/

Błach, J. (2018). Innowacje finansowe w przedsiębiorstwie. Instrumenty, mechanizmy, efekty. Warszawa: Wydawnictwo C.H. Beck.

Blaik, P. (2017). Logistyka. Koncepcja zintegrowanego zarządzania. Warszawa: Polskie Wydawnictwo Ekonomiczne. 
Bogusz, A. (2017). Koszty cyklu życia LCC. Efektywne zamówienia publiczne - wzmocnienie potencjatu administracji. Warszawa: Urząd Zamówień Publicznych.

Borowiecki, R., Siuta-Tokarska, B. i Żmija, K. (2017). Zarządzanie działalnością rozwojową przedsiębiorstwa. W: J. Kaczmarek i P. Krzemiński (red.), Doskonalenie działania przedsiębiorstw $i$ instytucji wobec przemian społeczno-gospodarczych: innowacje, finanse, otoczenie biznesu. Kraków: Fundacja Uniwersytetu Ekonomicznego w Krakowie.

Brdulak, A. (2014). Strategie rozwoju jednostek samorządów terytorialnych w kontekście świadczonych usług. W: R. Kłeczek i A. Pukas (red.), Usługi 2014. Sektor usług - uwarunkowania i tendencje rozwoju. PN 353. Wrocław: Wydawnictwo Uniwersytetu Ekonomicznego. http://dx.doi.org/10.15611/pn.2014.353.23

Bus.man.eu. (2021). MAN Lion's City. Pobrane 28 sierpnia $2021 \mathrm{z}$ https://www.bus.man.eu/ $\mathrm{pl} / \mathrm{pl} /$ autobusy-miejskie/lions-city-18/przeglad/przeglad-lions-city-18.html

Businessinsider.com.pl. (2020). Elektromobilność w komunikacji miejskiej ma się o wiele lepiej niż na rynku samochodowym. Pobrane 4 sierpnia $2021 \mathrm{z}$ https://businessinsider. com.pl/technologie/nowe-technologie/polskie-autobusy-elektryczne-jak-wyglada-rynek-elektromobilnosci/ps7ew6d

Businessinsider.com.pl. (2021). Bydgoska Pesa w tym roku chce zbudować lokomotywę na wodór. Pobrane 28 sierpnia $2021 \mathrm{z}$ https://businessinsider.com.pl/technologie/nowe-technologie/pesa-bydgoszcz-lokomotywa-na-wodor-wizualizacje-premiera-na-trako-2021/stphjfk

Cantwell, J. i Fai, F. (1999). Firms as the source of innovation and growth: the evolution of technological competence. J Evol Econ, 9, 331-366. Berlin, Heidelberg: Springer-Verlag GmbH. https://doi.org/10.1007/s001910050086

Chalmers.se. (2021). Self-driving buses in Gothenburg. Pobrane 15 lipca $2021 \mathrm{z}$ https:// www.chalmers.se/en/areas-of-advance/Transport/news/Pages/Self-driving-buses-in-Gothenburg.aspx

Chen J., Walker, R. M. i Sawhney, M. (2020). Public service innovation: a typology. Public Management Review, 22:11, 1674-1695. London: Taylor \& Francis Online. https://doi. org/10.1080/14719037.2019.1645874

Choromański, W., Garbarek, I., Kozłowski, M., Czerepicki, A. i Marczuk, K. (2020). Pojazdy autonomiczne i systemy transportu autonomicznego. Warszawa: Wydawnictwo Naukowe PWN.

Cichosz, M. (2015). Innowacje w logistyce miejskiej - zrównoważony transport publiczny. Prace Naukowe Uniwersytetu Ekonomicznego we Wrocławiu, 383, 26-39. Wrocław: Wydawnictwo Uniwersytetu Ekonomicznego. http://dx.doi.org/10.15611/pn.2015.383.02

Cng.auto.pl. (2021a). Autobusy zasilane CNG w Polsce. Pobrane 17 lipca 2021 z https://cng. auto.pl/2847/autobusy-zasilane-cng-w-polsce/

Cng.auto.pl. (2021b). LNG w Warszawie MZA podpisało kontrakt na dostawę 35 autobusów na gaz ziemny. Pobrane 17 lipca 2021 z https://cng.auto.pl/3142/lng-w-warszawie-mza-podpisalo-kontrakt-na-dostawe-35-autobusow-na-gaz-ziemny/

Czubiński, R. (2021). Warszawa: Będzie krótka seria autobusów wodorowych? Pobrane 4 sierpnia $2021 \mathrm{z}$ https://www.transport-publiczny.pl/wiadomosci/warszawa-bedzie-krotka-seria-autobusow-wodorowych-68129.html

Czyż, M. (2017). Wpływ jakości kapitału intelektualnego na innowacyjność przedsiębiorstwa. W: J. Kaczmarek i P. Krzemiński (red.), Doskonalenie działania przedsiębiorstw i instytucji 
wobec przemian społeczno-gospodarczych: innowacje, finanse, otoczenie biznesu. Kraków: Fundacja Uniwersytetu Ekonomicznego w Krakowie.

Czyżewska, M., Pach, J. i Sala, K. (red.). (2020). Ekonomia społeczna i przedsiębiorczość: innowacje - środowisko. Warszawa: CeDeWu.

Domański, R. (2006). Geografia ekonomiczna. Ujęcie dynamiczne. Warszawa: Wydawnictwo Naukowe PWN.

Drucker, P. (1992). Innowacja i przedsiębiorczość - praktyka i zasady. Warszawa: Polskie Wydawnictwo Ekonomiczne.

Dudzińska-Korczak, N. (2017). Analiza o ocena działalności innowacyjnej przedsiębiorstw w sektorze usługowym. W: J. Kaczmarek i P. Krzemiński (red.), Doskonalenie działania przedsiębiorstw i instytucji wobec przemian społeczno-gospodarczych: innowacje, finanse, otoczenie biznesu. Kraków: Fundacja Uniwersytetu Ekonomicznego w Krakowie.

Dybalski, J. (2018a). Gdańsk kupił 14 używanych autobusów z Berlina. Pobrane 28 sierpnia 2021 z https://www.transport-publiczny.pl/wiadomosci/gdansk-kupil-14-uzywanych-autobusow-z-berlina-59038.html

Dybalski, J. (2018b). Jaworzno całkiem elektryczne? Praga: Tak się nie da. Pobrane 28 sierpnia $2021 \mathrm{z}$ https://www.transport-publiczny.pl/wiadomosci/jaworzno-calkiem-elektryczne-praga-tak-sie-nie-da-58306.html

Dybalski, J. (2019). MZA Warszawa kupią 60 autobusów LNG. Na razie kupiły gaz z PGNiG. Pobrane 18 lipca $2021 \mathrm{z}$ https://www.transport-publiczny.pl/wiadomosci/mza-warszawa-kupia-60-autobusow-lng-na-razie-kupily-gaz-z-pgnig-61605.html

Dziadosz, A. (2015). Model oszacowania łącznych kosztów cyklu życia obiektu. W: T. Kasprowicz (red.), Inżynieria przedsięwzięć budowlanych. Rekomendowane metody i techniki. Warszawa: Komitet Inżynierii Lądowej i Wodnej Polskiej Akademii Nauk.

Ekoenergetyka.pl. (2021). Eko Energetyka - kim jesteśmy. Pobrane 31 sierpnia $2021 \mathrm{z}$ https:// ekoenergetyka.com.pl/pl/o-nas/

Epoznan.pl. (2020). Rozchodnik na dachach poznańskich przystanków. W tym roku podobnych wiat ma być jeszcze więcej. Pobrane 4 sierpnia $2021 \mathrm{z}$ https://epoznan.pl/news-news-103078-rozchodnik_na_dachach_poznanskich_przystankow_w_tym_roku_podobnych_wiat_ma_byc_jeszcze_wiecej

Feczko, P. (2016). Wspieranie innowacyjności przez samorząd terytorialny a związek metropolitarny. W: R. Lenart-Gansiniec, Innowacje w zarządzaniu. Warszawa: CeDeWu.

Feitelson, E. i Salomon, I. (2004). The political economy of transport innovations. W: M. Beuthe, V. Himanen, A. Reggiani i L. Zamparini (Eds.), Transport developments and innovations in an evolving world. Advances in spatial science. Berlin, Heidelberg: Springer-Verlag GmbH. https://doi.org/10.1007/978-3-540-24827-9_2

Fleming, S. (2021). Europe's first full-sized self-driving urban electric bus has arrived. Pobrane 4 sierpnia $2021 \mathrm{z}$ https://www.weforum.org/agenda/2021/03/europe-first-autonomous-electric-buses-spain/

Florczak, W. (2009). Koncepcja wzrostu endogenicznego i gospodarki opartej na wiedzy w naukach ekonomicznych. Studia Prawo-Ekonomiczne, 80, 215-239. Łódź: Łódzkie Towarzystwo Naukowe.

Fortune.com. (2021). A hydrogen-powered train will make transport history as Europe looks to become world leader in green rail travel. Pobrane 28 sierpnia $2021 \mathrm{z}$ https://fortune. com/2021/04/23/hydrogen-train-transport-europe-green-rail/ 
Fundacja MIR. (2021). Poznań: Znaczniki Totupoint dla osób niewidomych na trasie do ul. Włodarskiej. Pobrane 31 sierpnia 2021 z https://mir.org.pl/2021/08/26/poznan-znaczniki-totupoint-dla-osob-niewidomych-na-trasie-do-ul-wlodarskiej/

Gajda, P. i Bajdur, W. M. (2016). Innowacje w aspekcie zrównoważonego rozwoju społeczno-gospodarczego. W: R. Knosala, Innowacje w zarządzaniu i inżynierii produkcji (Tom 1). Opole: Oficyna Wydawnicza Polskiego Zarządzania Produkcją.

Gąsiorkiewicz, A., Sitarski, K., Sobolewska, O. i Wiśniewski, M. (2017). Gospodarka cyfrowa 2016. Zarządzanie, innowacje, społeczeństwo i technologie, Warszawa: Wydział Zarządzania Politechniki Warszawskiej.

Gdańskie Autobusy i Tramwaje. (2018a). 48 nowych autobusów trafi do Gdańska za 14 miesięcy. Zamiast kupować autobusy GAiT zamierza je dzierżawić. Pobrane 28 sierpnia $2021 \mathrm{z}$ https://www.gait.pl/aktualnosci/48-nowych-autobusow-trafi-do-gdanska-za-14-miesiecy-zamiast-kupowac-autobusy-gait-zamierza-je-dzierzawic/

Gdańskie Autobusy i Tramwaje. (2018b). Nowe autobusy dla Gdańska - podpisanie umowy. Pobrane 28 sierpnia $2021 \mathrm{z}$ https://www.gait.pl/aktualnosci/nowe-autobusy-dla-gdanska-podpisanie-umowy

Geerlings, H., Nijkamp, P. i Rietveld, P. (1997). Towards a new theory on technological innovations and network management: the introduction of environmental technology in the transport sector. W: C. S. Bertuglia, S. Lombardo i P. Nijkamp (Eds.), Innovative behaviour in space and time. Advances in spatial science. Berlin, Heidelberg: Springer-Verlag GmbH. https://doi.org/10.1007/978-3-642-60720-2_19

Giannopoulos, G. A. i Curdes, G. (2007). Innovations in urban transport and the influence on urban form. An historical review. Transport Reviews, 12:1, 15-32. London: Taylor \& Francis Online. https://doi.org/10.1080/01441649208716801

Gis, M. (2018). Autobusów z alternatywnym napędem będzie więcej. Który rodzaj zasilania wygra $w$ taborze polskich miast? Pobrane 1 sierpnia $2021 \mathrm{z}$ https://moto.pl/MotoPL/7,88389,23223898, autobusow-z-alternatywnym-napedem-bedzie-wiecej-ktory-rodzaj.html

Glapiński, A. (2012). Schumpeterowska teoria przedsiębiorcy, czyli skąd się bierze pies. Konsumpcja i rozwój, 2(1). Warszawa: Instytut Badań Rynku, Konsumpcji i Koniunktur.

Gługiewicz, Z. (red.). (1991). Transport miejski. Poznań: Wydawnictwo Akademii Ekonomicznej w Poznaniu.

Górka, K., Łuszczyk, M. i Thier, A. (2019). Ekonomia społeczna jako wyzwania dla współczesnych przedsiębiorstw. W: J. Pach, R. Śliwa i W. Maciejewski (red.), Przedsiębiorczość społeczna, innowacje, środowisko. Warszawa: CeDeWu.

Gorzałczyńska-Koczkodaj, M. i Szaja, M. (2013). Finansowanie prorozwojowych inwestycji samorządowych na przykładzie gmin nadmorskich województwa zachodniopomorskiego. Annales Universitatis Mariae Curie-Skłodowska. Sectio H. Oeconomia, 47(3), 197-208. Szczecin: Wydawnictwo Uniwersytetu Szczecińskiego.

Gostkowska-Dżwig, S. i Mrozik, M. (2017). Determinanty rozwoju jakości sektora usług transportu miejskiego w Częstochowie w aspekcie mobilności jej mieszkańców. Zeszyty Naukowe Politechniki Częstochowskiej. Zarządzanie, 26, 158-166. Częstochowa: Politechnika Częstochowska.

Greatercampridge.co.uk. (2021). Hundreds take part in ground-breaking autonomous shuttle passenger trial. Pobrane 15 lipca 2021 z https://www.greatercambridge.org.uk/news/ hundreds-take-part-in-ground-breaking-autonomous-shuttle-passenger-trial 
GreaterCambridge.org.uk. (2021). Zdjęcie pojazdu autonomicznego Cambridge. Pobrane 15 lipca $2021 \mathrm{z}$ https://www.greatercambridge.org.uk/news/hundreds-take-part-in-ground-breaking-autonomous-shuttle-passenger-trial; https://www.youtube.com/ watch? $=$ dwL2VVXshaw

Grochowiak, R., Dutkiewicz, P. i Chrobot, S. (2007). Atlas komunikacji miejskiej. Województwo Wielkopolskie. Poznań: Poznański Klub Modelarzy Kolejowych.

Gust-Barton, N. I. (2012). Innowacja w myśli ekonomicznej od XVIII do XX wieku: analiza wybranych zagadnień, Acta Universitatis Nicolai Copernici, Ekonomia, 43(1), 105-120. Toruń: Wydawnictwo Naukowe Uniwersytetu Mikołaja Kopernika.

Gwarda-Gruszczyńska, E. (2017). Dyfuzja innowacji - następstwo komercjalizacji nowych technologii, Organizacja i Kierowanie, 176(2), 383-396. Warszawa: Szkoła Główna Handlowa.

Hamrol, A. (2017). Zarządzanie i inżynieria jakości, Warszawa: Wydawnictwo Naukowe PWN. HEAT. (2021). Zdjęcie pojazdu wdrożonego $w$ ramach projektu HEAT. Pobrane 12 lipca 2021 z https://www.hochbahn.de/hochbahn/proxy/http/media.hochbahn.de/resize/900/kp/ Ausgangsseite/Naechster_Halt/Ausbau_und_Projekte/projekt_heat/HEAT870.jpg

Hill, A. (2020). Hamburg HEAT starts passenger operations. Pobrane 12 lipca $2021 \mathrm{z}$ https:// www.itsinternational.com/its6/news/hamburg-heat-starts-passenger-operations

Hochbahn.de. (2021a). The HEAT project. Pobrane 12 lipca $2021 \mathrm{z}$ https://www.hochbahn. de/hochbahn/hamburg/en/home/projects/expansion_and_projects/project_heat/

Infobus.pl. (2019a). Nowy MAN Lion's City w szczegółach. Pobrane 28 sierpnia $2021 \mathrm{z} \mathrm{http://}$ infobus.pl/nowy-man-lions-city-w-szczegolach-film-_more_103360.html

Infobus.pl. (2019b). Pierwsze rejestracje autobusów za rok 2018. Pobrane 28 sierpnia 2021 $\mathrm{z}$ http://infobus.pl/pierwsze-rejestracje-autobusow-za-rok-2018_more_111344.html

Infobus.pl. (2019c). Poznań: testy Solaris Urbino 12 Hybrid. Pobrane 15 sierpnia $2021 \mathrm{z} \mathrm{http://}$ www.infobus.pl/poznan-testy-solaris-urbino-12-hybrid_more_50956.html

Izba Gospodarcza Komunikacji Miejskiej. (2021). Komunikacja miejska w liczbach. Pobrane 31 sierpnia $2021 \mathrm{z}$ https://igkm.pl/statystyka/

Jakdojade.pl. (2021). Jakdojade Warszawa - wybrana trasa. Pobrane 31 sierpnia $2021 \mathrm{z}$ https://jakdojade.pl/warszawa/trasa/

Janasz, K. i Wiśniewska, J. (2017). Aktywność innowacyjna przedsiębiorstw w Polsce. W: J. Kaczmarek i P. Krzemiński (red.), Doskonalenie działania przedsiębiorstw i instytucji wobec przemian społeczno-gospodarczych: innowacje, finanse, otoczenie biznesu. Kraków: Fundacja Uniwersytetu Ekonomicznego w Krakowie.

Janasz, T. (2018). Digital technologies and business model innovations for urban mobility. W: Paradigm shift in urban nobility. Advances in information systems and business engineering. Wiesbaden: Springer Gabler. https://doi.org/10.1007/978-3-658-20460-0_3

Jurczak, M. (2006a). Klimatyzowane jamniki. Przystanek, 75(7), 1-12. Pobrane 15 sierpnia $2021 \mathrm{z}$ http://www.kmps.org.pl/przystanek/pdf/przystanek075.pdf

Jurczak, M. (2006b). Nowinki w Pyrogrodu, Przystanek, 75(7), 1-12. Pobrane 15 sierpnia $2021 \mathrm{z}$ http://www.kmps.org.pl/przystanek/pdf/przystanek075.pdf

Jurczak, M. (2013). Integracja i konkurencja jako sposoby kształtowania publicznego transportu zbiorowego na przykładzie aglomeracji poznańskiej, praca doktorska, Uniwersytet Ekonomiczny w Poznaniu, Poznań.

Jurczak, M. (2020). The role of IT systems in strategic management and building competitive advantage of companies in the logistics industry. W: K. Michalski (Eds.), Economics and 
organization of logistics - information systems in logistics and technologies in transport. Zeszyty Naukowe Szkoły Głównej Gospodarstwa Wiejskiego w Warszawie, 5, 29-40. Warszawa: Wydawnictwo Szkoły Głównej Gospodarstwa Wiejskiego.

Kaliszczak, L. (2011). Schumpeterowska teoria przedsiębiorczości i jej współczesne implikacje. Prace Naukowe Uniwersystetu Ekonomicznego we Wrocławiu. Nauki o Zarzadzaniu, 216 (8), 345-355. Wrocław: Wydawnictwo Uniwersytetu Ekonomicznego.

Kamiński, R. (2018). Istota innowacji (definicje, wyznaczniki i rodzaje). W: R. Kamiński (red.), Innowacje gospodarcze: wybrane aspekty ekonomiczne i prawne. Poznań: Wydawnictwo Naukowe Uniwersytetu im. Adama Mickiewicza.

Karaczun, A. (2008). Solaris: pierwsza hybryda dla MPK Poznań. Pobrane 23 lipca 2021 $\mathrm{z}$ https://www.auto-swiat.pl/wiadomosci/aktualnosci/solaris-pierwsza-hybryda-dla-mpk-poznan/bqt79bz

Kauf, S. (2013). Logistyka miasta jako podstawa kształtowania zachowań komunikacyjnych. Studia Miejskie, 10, 57-65. Opole: Wydział Ekonomiczny Uniwersytetu Opolskiego.

Kauf, S. i Tłuczak, A. (2014). Logistyka miasta i regionu. Metody ilościowe w decyzjach przestrzennych. Warszawa: Difin.

Kiba-Janiak, M. i Witkowski, J. (red.). (2014). Modelowanie logistyki miejskiej. Warszawa: Polskie Wydawnictwo Ekonomiczne.

Kisielewski, P. (2017). Wspomaganie logistyki transportu miejskiego z wykorzystaniem techniki informatycznej. Prace Naukowe Politechniki Warszawskiej. Transport, 115, 81-92. Warszawa: Politechnika Warszawska.

Kłeczek, R., Pluta-Olearnik, M. i Pukas, A. (2020). Transformacje praktyk mobilności miejskiej: usługi i wartości, rutyny i innowacje. Wrocław: Wydawnictwo Uniwersytetu Ekonomicznego

Kłos, Z. (2017). Innowacyjność i innowacje, Poznań: Wydawnictwo Politechniki Poznańskiej.

Komsta, H., Droździel, P. i Opielak, M. (2019). Rola miejskiego transportu publicznego w kreowaniu mobilności mieszkańców. Autobusy: technika, eksploatacja, systemy transportowe, 1-2, 393-397. Radom: Instytut Naukowo-Wydawniczy „Spatium”. http://dx.doi. org/10.24136/atest.2019.073

Kościelniak, H. (2015). Innowacyjność w przedsiębiorczości (zagadnienia wybrane). W: I. Dudzik-Lewicka, H. Howaniec i W. Waszkielewicz (red.), Zarzadzanie wiedza i innowacje $w$ organizacji, Bielsko-Biała: Akademia Techniczno-Humanistyczna.

Kozioł-Nadolna, K. (2014). Internacjonalizacja działalności badawczo-rozwojowej w kształtowaniu procesów innowacyjnych przedsiębiorstw w Polsce. Warszawa: CeDeWu.

Kozioł-Nadolna, K. i Suchocka, A. (2020). Innowacyjność wspótczesnych organizacji - ujęcie dynamiczne: innowacje w instytucji kultury, Szczecin: Wydawnictwo Naukowe Uniwersytetu Szczecińskiego.

Krajowe Ramy Polityki Rozwoju Infrastruktury Paliw Alternatywnych. (2017). Pobrane 20 sierpnia $2021 \mathrm{z}$ https://www.gov.pl/web/aktywa-panstwowe/rzad-przyjal-krajowe-ramy-polityki-rozwoju-infrastruktury-paliw-alternatywnych-3

Krakow.pl. (2020). Pierwszy w Polsce autonomiczny przejazd tramwaju. Pobrane 29 sierpnia $2021 \mathrm{z}$ https://www.krakow.pl/aktualnosci/236775,1912,komunikat,pierwszy_w_polsce_autonomiczny_przejazd_tramwaju.html

Kraśnicka, T. (2018). Innowacje w zarządzaniu. Nowe ujęcie, Warszawa: Wydawnictwo C.H. Beck. 
Kuhn, T. S. (2009). Struktura rewolucji naukowych, Warszawa: Wydawnictwo Aletheia.

Leśna-Wierszołowicz, E. (2016). Bariery innowacyjności w przedsiębiorstwie. W: M. M. Nowak i P. Dziekański, Innowacje jako element rozwoju regionu. Ostrowiec Świętokrzyski: Wyższa Szkoła Biznesu i Przedsiębiorczości .

Lissandrello, E., Hrelja, R., Tennøy, A. i Richardson, T. (2017). Three performativities of innovation in public transport planning, International Planning Studies, 22:2, 99-113. London: Taylor \& Francis Online. https://doi.org/10.1080/13563475.2016.1196579

Lubka, A. i Stiasny, M. (2004). Atlas tramwajów. Poznań: Poznański Klub Modelarzy Kolejowych.

Ludwiczak, A. (2016). Innowacyjność a rozwój gospodarki. Wybrane problemy i bariery. W: H. Mizgajska (red.), Przedsiębiorczość - innowacje - rozwój firmy, Kalisz: Wydawnictwo Państwowej Wyższej Szkoły Zawodowej im. Prezydenta Stanisława Wojciechowskiego.

MacKechnie, Ch. (2019). How Long Do Buses and Other Transit Vehicles Last? Pobrane 28 sierpnia $2021 \mathrm{z}$ https://www.thoughtco.com/buses-and-other-transit-lifetime-2798844

Madrjas, J. (2021). Sześć projektów wodorowych z szansa na dofinansowanie. Pobrane 25 sierpnia $2021 \mathrm{z}$ https://www.rynekinfrastruktury.pl/wiadomosci/drogi/szesc-projektow-wodorowych-z-szansa-na-dofinansowanie-77878.html

Malara, Z., Hrydziuszko, M. i Ziembicki, P. (2015). Innowacyjne modele biznesowe szansą na rozwój przedsiębiorstw. W: I. Dudzik-Lewicka, H. Howaniec i W. Waszkielewicz (red.), Zarządzanie wiedza i innowacje w organizacji. Bielsko-Biała: Akademia Techniczno-Humanistyczna.

Malik, N. i Niemczyk, M. (2016). Innowacyjność jako główne narzędzie budowy przewagi konkurencyjnej przedsiębiorstwa - z perspektywy pokolenia Y. W: R. Lenart-Gansiniec, Innowacje w zarzadzaniu. Warszawa: CeDeWu.

MamBiznes.pl. (2009). Najlepsze startupy roku 2009. Pobrane 7 sierpnia $2021 \mathrm{z}$ https:// mambiznes.pl/wlasny-biznes/wiadomosci/najlepsze-startupy-roku-2009-5459

Marczewska, M. (2016). Wiedza jako zasób kluczowy dla rozwoju ekoinnowacji w polskich firmach-dostawcach technologii środowiskowych. W: R. Lenart-Gansiniec, Innowacje w zarządzaniu. Warszawa: CeDeWu.

Markiewicz, J., Bielawa, A. i Tylżanowski, R. (2020). Oszczędne innowacje we współczesnym przedsiębiorstwie. Szczecin: Wydawnictwo Naukowe Uniwersytetu Szczecińskiego.

Markowski, R. (2017). Autobus LPG wraca na dobre? Pobrane 23 lipca $2021 \mathrm{z}$ https:/gazeo.pl/informacje/wiadomosci/Autobus-LPG-wraca-na-dobre,wiadomosc,9962.html

Maurer, M., Gerdes, J. Ch., Lenz, B. i Winner, H. (2016). Autonomous driving technical, legal and social aspects. Berlin, Heidelberg: Springer Verlag. https://doi.org/10.1007/978-3662-48847-8

McMurtry, A. (2021). Europe's first self-driving bus hits the road in Spain. Pobrane 4 sierpnia $2021 \mathrm{z}$ https://www.aa.com.tr/en/europe/europe-s-first-self-driving-bus-hits-the-road-in-spain/2162259\#

Mercedes-benz.com. (2021). Citaro: Komfort dla pasażerów. Pobrane 28 sierpnia 2021 z https://www.mercedes-benz-bus.com/pl_PL/models/citaro/comfort-and-design/ comfort-passenger.html

Ministerstwo Infrastruktry. (2013). Strategia rozwoju transportu do 2020 roku (z perspektywa do 2030 roku). Pobrane 15 sierpnia $2021 \mathrm{z}$ https://www.gov.pl/static/mi_arch/ media/3511/Strategia_Rozwoju_Transportu_do_2020_roku.pdf 
Misiurski, P. (2017). Analiza statystyczna danych miejskiego transportu autobusowego w wymiarze regionalnym. Autobusy: technika, eksploatacja, systemy transportowe, 11, 24-29. Radom: Instytut Naukowo-Wydawniczy „Spatium”.

Młodzik, E. (2015). Założenia koncepcji New Public Management, Zeszyty Naukowe Uniwersytetu Szczecińskiego. Współczesne Problemy Ekonomiczne. Globalizacja. Liberalizacja. Etyka, 11, 183-193. Szczecin: Uniwersytet Szczeciński. https://doi.org/10.18276/ wpe.2015.11-17

Modertrans.pl. (2021). Moderus Gamma LF 05 AC zaprezentowany! Pobrane 31 sierpnia $2021 \mathrm{z}$ http://www.modertrans.pl/1907-2/

Molecki, A. (2017). Prezentacja rozwiązań z zakresu elektromobilności w fabryce Volvo. Autobusy: technika, eksploatacja, systemy transportowe, 10, 34-36. Radom: Instytut Naukowo-Wydawniczy „Spatium”.

MPK Kraków. (2021a). Miejskie Przedsiębiorstwo Komunikacyjne S.A. w Krakowie - historia. Pobrane 9 lipca $2021 \mathrm{z}$ https://www.mpk.krakow.pl/pl/historia/

MPK Kraków. (2021b). Miejskie Przedsiębiorstwo Komunikacyjne S.A. w Krakowie - organizacja. Pobrane 9 lipca $2021 \mathrm{z}$ https://www.mpk.krakow.pl/pl/organizacja/

MPK Kraków. (2021c). Miejskie Przedsiębiorstwo Komunikacyjne S.A. w Krakowie - zakres działania MPK. Pobrane 9 lipca 2021 z https://www.mpk.krakow.pl/pl/zakres-dzialania-mpk/

MPK Kraków. (2021d). MPK przygotowuje się do zakupu 40 autobusów zasilanych wodorem. Pobrane 29 sierpnia $2021 \mathrm{z}$ https://www.mpk.krakow.pl/pl/aktualnosci/news,9669,mpk-przygotowuje-sie-do-zakupu-40-autobusow-zasilanych-wodorem.html

MPK Poznań. (2009). Zakup 25 autobusów Solaris Urbino. Nadchodzq zielone jamniki. Pobrane 28 sierpnia $2021 \mathrm{z}$ https://www.mpk.poznan.pl/o-mpk/inwestycje/179-zakup-25-autobusow-solaris-urbino/684-nadchodza-zielone-jamniki

MPK Poznań. (2011). UE - zakup 26 autobusów Solaris Urbino MIDI. Flota autobusowa wciąż się wzbogaca. Pobrane 28 sierpnia 2021 z https://www.mpk.poznan.pl/o-mpk/ inwestycje/180-ue-zakup-26-autobusow-solaris-urbino-midi/1842-flota-autobusowa-wciaz-sie-wzbogaca

MPK Poznań. (2012). Największa w Polsce i pierwsza zarządzana automatycznie - taka będzie zajezdnia Franowo. Pobrane 31 sierpnia 2021 z https:/www.mpk.poznan.pl/o-mpk/ inwestycje/infrastruktura/87-ue-zajezdnia-franowo/1985-najwieksza-w-polsce-i-pierwsza-zarzadzana-automatycznie-taka-bedzie-zajezdnia-franowo

MPK Poznań. (2016). 20 autobusów Solaris Urbino IV generacji. Autobusy najnowszej generacji dla Poznania. Pobrane 28 sierpnia $2021 \mathrm{z}$ https://www.mpk.poznan.pl/o-mpk/ inwestycje/235-20-autobusow-solaris-urbino-4-generacji/2993-autobusy-najnowszej-generacji-dla-poznania

MPK Poznań. (2017). Autobusy najnowszej generacji dla Poznania. Pobrane 28 sierpnia $2021 \mathrm{z}$ https://www.mpk.poznan.pl/o-mpk/inwestycje/247-37-autobusow-solaris-urbino-12-i-18/3934-autobusy-najnowszej-generacji-dla-poznania

MPK Poznań. (2021a). Kolejny etap Programu Centrum. Zmiany w komunikacji od 10 kwietnia. Pobrane 27 sierpnia $2021 \mathrm{z}$ https://www.mpk.poznan.pl/aktualnosci/4335-kolejny-etap-programu-centrum-zmiany-w-komunikacji-od-10-kwietnia

MPK Poznań. (2021b). MPK Poznań stara się o dofinansowanie na zakup autobusów napędzanych wodorem. Pobrane 4 sierpnia $2021 \mathrm{z}$ https://www.mpk.poznan.pl/aktualno- 
sci/4293-mpk-pozna-stara-si-o-dofinansowanie-na-zakup-autobusow-napdzanych-wodorem

Mucha, A. (2019). Pojęcie innowacyjności w nauce i praktyce. W. J. Pach, R. Śliwa i W. Maciejewski, (red.), Przedsiębiorczość społeczna, innowacje, środowisko. Warszawa: CeDeWu.

Mucha, A. (2020). Innowacyjność determinantą działania Unii Europejskiej. W: M. Czyżewska, J. Pach i K. Sala, (red.), Ekonomia społeczna i przedsiębiorczość: innowacje środowisko. Warszawa: CeDeWu.

Muras, M. i Zabłocki, W. (2013). Zastosowanie teorii dyfuzji innowacji na przykładzie wprowadzenia na rynek Airbusa A380. Prace Naukowe Politechniki Warszawskiej. Transport, 89, 135-148. Warszawa: Politechnika Warszawska.

Murzyn, D. (2020). Innowacje inkluzywne jako szansa na włączenie grup marginalizowanych w procesy rozwoju i zmniejszenie nierówności społecznych. W: M. Czyżewska, J. Pach i K. Sala, (red.), Ekonomia społeczna i przedsiębiorczość: innowacje - środowisko. Warszawa: CeDeWu.

MZA. (2021). Projekt zakupu elektrycznych autobusów. Pobrane 4 sierpnia $2021 \mathrm{z}$ https:// www.mza.waw.pl/o-nas/projekt-zakupu-elektrycznych-autobusow/

Neumann, T. (2018). Perspektywy wykorzystania pojazdów autonomicznych w transporcie drogowym w Polsce, Autobusy: technika, eksploatacja, systemy transportowe, 12, 787-794. Radom: Instytut Naukowo-Wydawniczy „Spatium”. https://doi.org/10.24136/ atest.2018.499

NHTSA. (2021). Automated Vehicles for Safety. Pobrane 24 sierpnia z https://www.nhtsa. gov/technology-innovation/automated-vehicles-safety

Nowotyńska, I. i Kut, S. (2016). Nowoczesne systemy transportowe w komunikacji miejskiej. Autobusy: technika, eksploatacja, systemy transportowe, 12, 1643-1646. Radom: Instytut Naukowo-Wydawniczy „Spatium”.

Openstreetmap.org. (2021). Podkład mapy do schematu układu torowego. Pobrane 27 sierpnia $2021 \mathrm{z}$ https://www.openstreetmap.org

Oramus, M. (2015). Model współzarządzania (governance) i problemy dotyczące jego wdrażania w administracji publicznej, Rocznik Administracji publicznej, 1, 179-195. Kraków: Uniwersytet Pedagogiczny im. Komisji Edukacji Narodowej.

Osbert-Pociecha, G. (2018). Innowacje - zagadnienia ogólne i definicyjne. W: A. Styś i A. Dejnaka, (red.), Innowacje w biznesie, Warszawa: Difin.

Owczarzak, W. (2016). Autobusy napędzane CNG w Polsce. Autobusy: technika, eksploatacja, systemy transportowe, 6, 656-657. Radom: Instytut Naukowo-Wydawniczy „Spatium”.

Owsiak, S. (2005). Finanse publiczne. Teoria i praktyka. Warszawa: Wydawnictwo Naukowe PWN.

Parlament Europejski i Rada. (2007). Rozporządzenie Parlamentu Europejskiego i Rady (WE) nr 1370/2007 z dnia 23 października 2007 r., dotyczącego usług publicznych w zakresie kolejowego i drogowego transportu pasażerskiego. Pobrane 14 sierpnia $2021 \mathrm{z} \mathrm{http://}$ eur-lex.europa.eu/LexUriServ/LexUriServ.do?uri=OJ:L:2007:315:0001:0013:PL:PDF

Pędziwiatr, K. i Kasińska, J. (2017). Innowacje w transporcie miejskim pasażerów uwzględniające potrzeby osób o ograniczonej mobilności na przykładzie miasta Berlin. Studia Miejskie, 27, 81-90. Opole: Wydział Ekonomiczny Uniwersytetu Opolskiego.

Pieniacka, E. M. (2016). W kierunku innowacyjności. Istota strategii innowacji. W: R. Lenart-Gansiniec, Innowacje w zarządzaniu. Warszawa: CeDeWu. 
Pieniacka, E. M. (2018). Innowacje jako fundament rozwoju organizacji w XXI w. W: A. Styś i A. Dejnaka, (red.), Innowacje w biznesie, Warszawa: Difin.

Pięta, M. (2002). Powstanie klasycznych teorii lokalizacji i ich ewolucja w kierunku teorii polaryzacji. W: K. Szołek (red.), Aglomeracja miejska i jej znaczenie dla konkurencyjności miast i regionów. Biblioteka Regionalistyki, 2. Wrocław: Wydawnictwo Katedry Polityki Ekonomicznej i Europejskich Studiów Regionalnych, Akademia Ekonomiczna im. Oskara Langego.

Pire.pl. (2021). 468 elektrobusów na polskich drogach. Pobrane 4 sierpnia $2021 \mathrm{z} \mathrm{https://pire.}$ pl/468-elektrobusow-na-polskich-drogach/

Podręcznik Frascati. (2015). Pobrane 15 sierpnia $2021 \mathrm{z}$ https://www.oecd.org/sti/inno/ frascati-manual.htm

Podręcznik Oslo. (2018). Pobrane 15 sierpnia 2021 z https://www.oecd.org/science/oslo-manual-2018-9789264304604-en.htm

Polinkevych, O. (2018). Ewolucja procesu innowacyjnego i zarządzanie innowacjami. W: R. Kamiński (red.), Innowacje gospodarcze: wybrane aspekty ekonomiczne i prawne. Poznań: Wydawnictwo Naukowe Uniwersytetu im. Adama Mickiewicza.

Połom, M., Piasecki, A. i Bartłomiejczyk, M. (2015). Charakterystyka autonomiczności trolejbusów - nowe doświadczenia w elektromobilności miejskiej. Logistyka, 4, 53945401, CD2. Poznań: Instytut Logistyki i Magazynowania.

Polskie Górnictwo Naftowe i Gazownictwo. (2021). CNG - co warto o nim wiedzieć. Pobrane 17 lipca $2021 \mathrm{z}$ https://pgnig.pl/cng

Porada-Rochoń, M., Brojak-Trzaskowska, M., Kordela, D. i Tomczyk, M. (2018). Przedsiębiorstwa w obliczu wyzwań XXI wieku: modele biznesowe, finansowanie, innowacje. Kraków / Legionowo: Wydawnictwo edu-Libri.

Poznan.pl. (2020). Inauguracja Poznańskiej Rady Transportu Aglomeracyjnego. Pobrane 4 sierpnia $2021 \mathrm{z}$ https://www.poznan.pl/mim/info/news/inauguracja-poznanskiej-rady-transportu-aglomeracyjnego,156792.html

Radiopoznan.fm. (2021). MPK chce kupić ponad 80 autobusów zasilanych wodorem. Pobrane 1 sierpnia $2021 \mathrm{z}$ https://radiopoznan.fm/informacje/kluczowy-temat/k-dostatni

Raport Kolejowy.pl. (2018). MEDCOM eksportuje i zdobywa kolejne rynki na świecie. Pobrane 31 sierpnia $2021 \mathrm{z}$ https://raportkolejowy.pl/medcom-eksportuje-i-zdobywa-kolejne-rynki-na-swiecie/

Regional Verkehr. (2004). Der Combino Duo in Nordhausen, Regional Verkehr, 3. Pobrane 28 sierpnia $2021 \mathrm{z}$ http://www.regionalverkehr.de/pages/rv_meld_040325.htm

Rejmoniak, A. (1985). Kryteria sprawności działania systemu komunikacji miejskiej. Transport Miejski, 12, 252-254. Warszawa / Kraków: Stowarzyszenie Inżynierów i Techników Komunikacji RP.

Rekowski, M. (2002). Wprowadzenie do mikroekonomii. Poznań: Wydawnictwo Akademii Ekonomicznej.

Rösler, J. (2021a). Poznań blisko zakupu 25 autobusów wodorowych. Pobrane 10 grudnia $2021 \mathrm{z}$ https://www.transport-publiczny.pl/wiadomosci/poznan-blisko-zakupu-25-autobusow-wodorowych-71567.html

Rösler, J. (2021b). Warszawa zazielenia pętle komunikacji miejskiej. Pobrane 4 sierpnia 2021 z https://www.transport-publiczny.pl/wiadomosci/warszawa-zazielenia-petle-komunikacji-miejskiej-69780.html 
Rudkowski, M. i Dybaś, K. (2000). Zastosowanie gazów jako alternatywnych paliw silnikowych $w$ transporcie samochodowym. Pobrane 21 lipca $2021 \mathrm{z}$ https://www.cire.pl/pliki/2/ Zastosowanie_gazow2061673686.pdf

Rusak, Z. (2008a). Autobusy hybrydowe koncernu Daimler AG. Autobusy: technika, eksploatacja, systemy transportowe, 4, 14-22. Radom: Instytut Naukowo-Wydawniczy „Spatium”. Rusak, Z. (2008b). Solaris Urbino Hybrid - druga odsłona. Autobusy: technika, eksploatacja, systemy transportowe, 7-8, 20-24. Radom: Instytut Naukowo-Wydawniczy „Spatium”.

Rusak, Z. (2018). Elektromobilność według Solarisa. Autobusy: technika, eksploatacja, systemy transportowe, 9, 10-27. Radom: Instytut Naukowo-Wydawniczy „Spatium”.

Rymarz, J., Stokłosa, J. i Niewczas, A. (2014). Wybrane problemy efektywności funkcjonowania transportu zbiorowego. Logistyka, 3, 5542-5548. Poznań: Instytut Logistyki i Magazynowania.

Schumpeter, J. (1960). Teoria rozwoju gospodarczego. Warszawa: Państwowe Wydawnictwo Naukowe.

Schumpeter, J. (1966). Imperialism. Social classes. Cleveland and New York: Meridian Books, The World Publishing Company.

Siemens.com. (2021). Teaching trams to drive. The eyes and brain of the system. Pobrane 29 sierpnia $2021 \mathrm{z}$ https://assets.new.siemens.com/siemens/assets/api/uuid:bc2811c4-3d26-460d-9472-9372d5ce32d7/autonomous-tram.pdf

Skalski, P. (2017). Autobusy elektryczne w Polsce. Autobusy: technika, eksploatacja, systemy transportowe, 12, 415-418. Radom: Instytut Naukowo-Wydawniczy „Spatium”.

Ślusarczyk, S. (2020). Główne kierunki aktywności innowacyjnej przedsiębiorstw w Polsce. W: M. Czyżewska, J. Pach i K. Sala, (red.), Ekonomia społeczna i przedsiębiorczość: innowacje - środowisko. Warszawa: CeDeWu.

Smith, G., Sochor, J. i Karlsson, I. C. M. (2019). Public-private innovation: barriers in the case of mobility as a service in west Sweden. Public Management Review, 21:1, 116-137. London: Taylor \& Francis Online. https://doi.org/10.1080/14719037.2018.1462399

Solarisbus.com. (2018). Solaris. Katalog produktowy 2018. Napęd konwencjonalny. Pobrane 28 sierpnia $2021 \mathrm{z}$ https://www.solarisbus.com/public/assets/content/pojazdy/katalog/ PL_Napdy_konwencjonalne_2018_-_wersja_elektroniczna_small.pdf

Solarisbus.com. (2021). 25 lat firmy Solaris. Informacja prasowa. Pobrane 28 sierpnia 2021 z https://www.solarisbus.com/pl/biuro-prasowe-solaris-bus-coach-sp-z-o-o/pdf/1499

Sopińska, A. i Dziurski, P. (2018). Otwarte innowacje. Perspektywa wspótpracy i zarzadzania wiedza. Warszawa: Oficyna Wydawnicza Szkoły Głównej Handlowej.

Sosnowski, J. i Nowakowski, Ł. (2020). Innowacje kreujące nowe wartości $w$ transporcie samochodowym. Łódź: Wydawnictwo Uniwersytetu Łódzkiego.

Stabryła, A. (2017). Wykładnia zdolności rozwojowej jako podstawa oceny dojrzałości procesowej przedsiębiorstwa. W: J. Kaczmarek i P. Krzemiński (red.), Doskonalenie działania przedsiębiorstw $i$ instytucji wobec przemian społeczno-gospodarczych: innowacje, finanse, otoczenie biznesu. Kraków: Fundacja Uniwersytetu Ekonomicznego w Krakowie.

Stępnicka, N. (2013). Koncepcja twórczej destrukcji J.A. Schumpetera a wyzwania współczesnej gospodarki. Studia Ekonomiczne: Wspótczesne problemy ekonomiczne: wybrane zagadnienia teoretyczne a praktyka gospodarcza, 129, 34-38. Katowice: Uniwersytet Ekonomiczny.

Stiglitz, J. E. (red.). (2013). Ekonomia sektora publicznego. Warszawa: Wydawnictwo Naukowe PWN. 
Suda, J. (2017). Innowacyjne zarządzanie miejskim transportem publicznym. Prace Naukowe Politechniki Warszawskiej, 118, 265-276. Warszawa: Oficyna Wydawnicza Politechniki Warszawskiej.

Sustainable-bus.com. (2019). Scania bus runs on LNG for the first time. A European premiere in Bologna. Pobrane 19 lipca $2021 \mathrm{z}$ https://www.sustainable-bus.com/news/the-first-1ng-buses-in-europe-are-on-the-road-scania-delivery-in-bologna/

Szołtysek, J. (2005). Logistyczne aspekty zarządzania przepływami osób i ładunków w miastach. Prace naukowe Akademii Ekonomicznej w Katowicach, 2009. Katowice: Wydawnictwo Akademii Ekonomicznej.

Szołtysek, J. (2011). Kreowanie mobilności mieszkańców miast. Warszawa: Wolters Kluwer Polska.

Szołtysek, J. (2016). Logistyka miasta. Warszawa: Polskie Wydawnictwo Ekonomiczne.

Szukalski, S. (2018). Wybrane aspekty innowacyjności i konkurencyjności przedsiębiorstw usługowych. W: S. Szukalski, M. Wodnicka i B. Wentura-Dudek (red.), Innowacje i trendy we współczesnej gospodarce. Kraków: Foundation for Innovation Development and Science (FIDAS).

Szumowski, W. (2014). Zarządzanie publiczne - próba systematyzacji koncepcji. Nauki o Zarządzaniu, 21(4), 86, 98. Wrocław: Wydawnictwo Uniwersytetu Ekonomicznego.

Szymczak, M. (2018). Ekonomia „na żądanie” i jej wpływ na logistykę miasta. Studia Miejskie, 30, 25-38. Opole: Wydział Ekonomiczny Uniwersytetu Opolskiego. http://dx.doi. org/10.25167/sm2018.030.02

Take\&drive. (2021). Widok mapy i pojazdów w aplikacji webowej takełdrive. Pobrane 29 sierpnia $2021 \mathrm{z}$ https://takeanddrive.eu/map.html

Tomanek, R. (red.) (2007). Ceny transportu miejskiego w Europie. Prace naukowe Akademii Ekonomicznej im. Karola Adamieckiego w Katowicach. Katowice: Wydawnictwo Akademii Ekonomicznej.

Tomaszewska, E. J. (2015). Inteligentny system transportowy w mieście na przykładzie Białegostoku. Zeszyty Naukowe Uniwersytetu Szczecińskiego. Problemy Zarządzania, Finansów i Marketingu, 41, 317-329. Szczecin: Wydawnictwo Naukowe Uniwersytetu Szczecińskiego. http://dx.doi.org/DOI\%3A10.18276/pzfm.2015.41/2-26

Tramwar.pl. (2021). Tramwaje Warszawskie - strona prywatna. Wagon typu 116N. Pobrane 25 sierpnia $2021 \mathrm{z} \mathrm{http://tramwar.pl/tw116n.html}$

Transinfo.pl. (2020). Polska - europejskim liderem LNG $w$ miejskich autobusach. Pobrane 17 lipca $2021 \mathrm{z}$ https://transinfo.pl/infobus/polska-europejskim-liderem-lng-w-miejskich-autobusach-_more_123838/

Transport-publiczny.pl. (2021). Autobusy miejskie napędzaja sprzedaż gazu CNG. Wzrost o ponad 30\%. Pobrane 17 lipca 2021 z https://www.transport-publiczny.pl/wiadomosci/ autobusy-miejskie-napedzaja-sprzedaz-gazu-cng-wzrost-o-ponad-30-67450.html

Tutaj, J. (2019). Innowacje - próba pomiaru. W: Z. Malara i J. Tutaj (red.), Innowacje a dobrostan społeczeństwa, gospodarki i przedsiębiorstw: próba pomiaru. Wrocław: Oficyna Wydawnicza Politechniki Wrocławskiej.

Tuziak, A. (2019). Społeczny wymiar dyfuzji innowacji i wiedzy jako czynników zmiany i rozwoju gospodarczego. Nierówności Społeczne a Wzrost Gospodarczy, 57(1), 327-341. Rzeszów: Wydawnictwo Uniwersytetu Rzeszowskiego. http://dx.doi.org/10.15584/nsawg.2019.1.23 
UM Warszawa. (2021). Największa stacja ładowania powstaje w Wilanowie. Pobrane 4.08.2021 $\mathrm{z}$ https://um.warszawa.pl/-/najwieksza-stacja-ladowania-powstaje-w-wilanowie

Urbanowicz, W. (2017). Warszawa: Mobilis z umowa. Wprowadzi do ruchu hybrydowe MAN- $y$. Pobrane 5 listopada $2021 \mathrm{z}$ https://www.transport-publiczny.pl/wiadomosci/ warszawa-mobilis-z-umowa-wprowadzi-do-ruchu-hybrydy-57174.html

Urbanowicz, W. (2020). MZA Warszawa rozstrzygnęły przetarg na 90 autobusów LNG. Pobrane 18 lipca $2021 \mathrm{z}$ https://www.transport-publiczny.pl/wiadomosci/mza-warszawa-rozstrzygnely-przetarg-na-90-autobusow-lng-65427.html

Urząd Zamówień Publicznych. (2021). Szczegóty postępowania: Wykonywanie usług autobusowego transportu publicznego na obszarze działania Zarządu Transportu Metropolitalnego. Pobrane 5 listopada $2021 \mathrm{z}$ https://miniportal.uzp.gov.pl/Postepowania/1bdc33c7-19e8-4f9d-982c-193665124397.

Ustawa z dnia 11 stycznia 2018 r. o elektromobilności i paliwach alternatywnych (Dz. U. z 2018 r., poz. 317, stan na dzień 13.07.2021). Pobrane 20 sierpnia 2021 z https://isap. sejm.gov.pl/isap.nsf/DocDetails.xsp?id=WDU20180000317

Ustawa z dnia 16 grudnia 2010 r. o publicznym transporcie zbiorowym (Dz. U. z $2011 \mathrm{r}$. Nr 5, poz. 13 z późn. zm., stan na dzień 16.08.2021). Pobrane 20 sierpnia 2021 z http:// isap.sejm.gov.pl/isap.nsf/DocDetails.xsp?id=wdu20110050013

Ustawa z dnia 20 czerwca 1997 r. Prawo o ruchu drogowym (Dz. U. z 2021 r., poz. 450, 463, 694, 720, stan na dzień 8.06.2021). Pobrane 12 lipca $2021 \mathrm{z}$ https://isap.sejm.gov.pl/isap. nsf/DocDetails.xsp?id=WDU20210000450

Visitwroclaw.eu. (2021). Polinka - kolejka linowa we Wrocławiu. Pobrane 29 sierpnia 2021 $\mathrm{z}$ https://visitwroclaw.eu/miejsce/polinka-wroclaw

Warszawski Transport Publiczny. (2021). Rada WTP. Pobrane 4 sierpnia $2021 \mathrm{z}$ https:// www.wtp.waw.pl/rada-wtp/

Węgrzyn, G. (2014). Zróżnicowanie innowacji w sektorze usług w krajach Unii Europejskiej. W: R. Kłeczek i A. Pukas (red.), Usługi 2014. Sektor usług - uwarunkowania i tendencje rozwoju. PN 353. Wrocław: Wydawnictwo Uniwersytetu Ekonomicznego. http://dx.doi. org/10.15611/pn.2014.353.21

Wojcieszak, J. (2000). 120 lat komunikacji miejskiej w Poznaniu. Poznań: Wydawnictwo Miejskie.

Wolański, M. (2011). Efektywność ekonomiczna demonopolizacji komunikacji miejskiej w Polsce. Warszawa: Oficyna Wydawnicza Szkoły Głównej Handlowej.

Wolański, M. i Pieróg, M. (2017). Rozwój komunikacji miejskiej w Polsce w latach 20092015. Autobusy: technika, eksploatacja, systemy transportowe, 6, 25-29. Radom: Instytut Naukowo-Wydawniczy „Spatium”.

Wroclaw.pl. (2016). Stużby miejskie gotowe na Wszystkich Świętych. Pobrane 24 sierpnia 2021 z https://www.wroclaw.pl/sluzby-miejskie-gotowe-na-wszystkich-swietych

Wroński, M. (2021). Konin będzie miał pierwszy autobus wodorowy w Polsce. Pobrane 4 sierpnia $2021 \mathrm{z}$ https://www.portalsamorzadowy.pl/gospodarka-komunalna/konin-bedzie-mial-pierwszy-autobus-wodorowy-w-polsce,296007.html

Wyszomirski, O. (red.). (1997). Komunikacja miejska w gospodarce rynkowej. Gdańsk: Wydawnictwo Uniwersytetu Gdańskiego.

Wyszomirski, O. (red.). (2010). Transport miejski. Ekonomika i organizacja. Gdańsk: Wydawnictwo Uniwersytetu Gdańskiego. 
Zarząd Dróg Miejskich i Komunikacji Publicznej w Bydgoszczy. (2021). Dokumentacja przetargowa $w$ postępowaniu: 015/2021. Świadczenie ustug przewozowych na liniach autobusowych w Bydgoszczy w latach 2023-2031. Pobrane 5 listopada $2021 \mathrm{z}$ https:// platformazakupowa.pl/transakcja/466483

Zarząd Transportu Miejskiego w Poznaniu. (2021). Poznańska Rada Transportu Aglomeracyjnego. Pobrane 4 sierpnia $2021 \mathrm{z}$ https://www.ztm.poznan.pl/pl/kontakt-2/poznanska-rada-transportu-aglomeracyjnego/

Zarząd Transportu Miejskiego w Warszawie. (2021a). Zadania ZTM. Pobrane 9 lipca 2021 z https://www.ztm.waw.pl/o-ztm/zadania-ztm/

Zarząd Transportu Miejskiego w Warszawie. (2021b). Zarząd Transportu Miejskiego w Warzawie. Raport 2020. Pobrane 10 lipca $2021 \mathrm{z}$ https://www.ztm.waw.pl/wp-content/ uploads/2021/03/Raport_roczny_2020-1.pdf

Zarząd Transportu Miejskiego w Warszawie. (2021). Informator ZTM w Warszawie, nr VI (327), czerwiec 2021. Pobrane 27 sierpnia $2021 \mathrm{z} \mathrm{https://www.ztm.waw.pl/wp-content/}$ uploads/2021/08/www-BIULETYN-CZERWIEC-2021.pdf

Zarząd Transportu Publicznego w Krakowie. (2021). Operatorzy KMK. Pobrane 9 lipca 2021 z http://kmkrakow.pl/informacje-o-systemie-kmk/zasady-funkcjonowania-systemu. html

Zawicki, M. (2013). Nowe zarządzanie publiczne. Warszawa: Polskie Wydawnictwo Ekonomiczne.

Żelichowska, M. i Lis, T. (2015). Proces innowacji zorientowanej na klienta jako element strategii działania przedsiębiorstwa. W: I. Dudzik-Lewicka, H. Howaniec i W. Waszkielewicz (red.), Zarzadzanie wiedza i innowacje w organizacji. Bielsko-Biała: Akademia Techniczno-Humanistyczna.

Ziembicki, M. i Pyza, D. (2018). Paliwa alternatywne w transporcie publicznym i wynikające z ich eksploatacji ograniczenia. Prace Naukowe Politechniki Warszawskiej. Transport, 121, 441-451. Warszawa: Politechnika Warszawska.

Złoty, P. (2011). Ciężki transport na LPG? Pobrane 21 lipca $2021 \mathrm{z}$ https://gazeo.pl/informacje/samochody/uzytkowe/Ciezki-transport-na-LPG,artykul,1518.html 


\section{SPIS TABEL I RYSUNKÓW}

Tabele

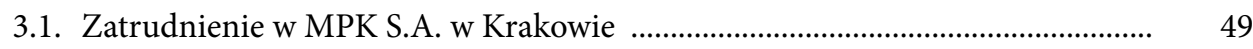

3.2. Tabor autobusowy MPK S.A. w Krakowie ............................................................ 50

3.3. Tabor tramwajowy MPK S.A. w Krakowie ............................................................. 50

3.4. Zestawienie operatorów w sieci ZTM Warszawa z uwzględnieniem liczby wozów w ruchu

3.5. Wysokość stawki za wozokm w sieci Zarządu Transportu Miejskiego w Warszawie

4.1. Klasyfikacja innowacji według wybranych kryteriów

Rysunki

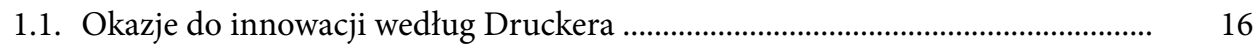

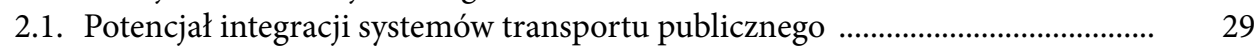

2.2. Potencjał integracji systemów transportu publicznego II ..................................... 29

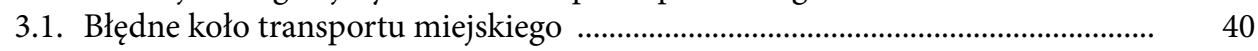

3.2. Operatorzy Warszawskiego Transportu Publicznego .......................................... 52

3.3. Autobus Solaris Urbino 12 Hybrid testowany przez Miejskie Przedsiębiorstwo Komunikacyjne w Poznaniu .................................................................................. 59

3.4. Autobus Solaris Urbino 12 Hybrid wyposażony w fotelik dziecięcy ................... 60

4.1. Wyposażenie autobusów i tramwajów w udogodnienia dla pasażerów ............. 71

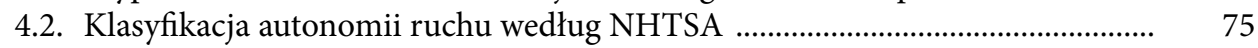

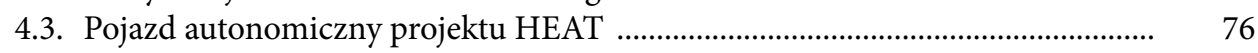

4.4. Pojazd autonomiczny projektu Cambridge ............................................................ 77

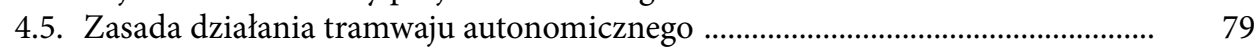

4.6. Sprzedaż autobusów miejskich na rynku polskim, z podziałem na źródła napędu

4.7. Udział pojazdów zeroemisyjnych i niskoemisyjnych w strukturze taboru autobusowego w 2019 roku ............................................................................................ 83

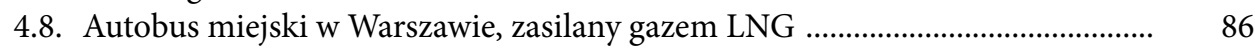

4.9. Autobus elektryczny w Poznaniu .......................................................................... 91 
4.10. Aplikacje mobilne dla pasażerów - Wirtualny monitor i Kiedy pojadę

4.11. Dyspozytorzy MPK w Centrum Zarządzania Ruchem i Transportem Publicznym we Wrocławiu

4.12. Przykładowa trasa przejazdu w planerze podróży Jak dojadę .............................. 101

4.13. Automat biletowy w pojeździe MPK Wrocław ..................................................... 102

4.14. Sygnalizacja świetlna $\mathrm{z}$ sekundnikiem, Wrocław ................................................. 103

4.15. Od zarządzania strategicznego do zarządzania informacją ................................. 105

4.16. Aplikacja Takeひdrive - dostępność pojazdów z wielu systemów współdzielenia 107

4.17. Schemat układu torowego dla torowiska tymczasowego ....................................... 109

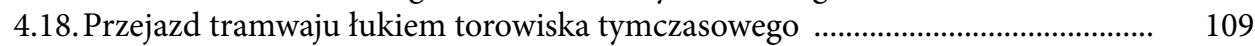

4.19. Przejazd tramwaju torowiskiem tymczasowym w Ostrawie .................................. 110

4.20. Kolejka linowa „Polinka” we Wrocławiu ............................................................. 112 


\section{SUMMARY INNOVATIONS IN PUBLIC TRANSPORT}

The main aim of this publication is to create the first comprehensive study on the use of innovations in public transport: to bring together all the available knowledge connected with innovations in public transport companies, as well as on innovation in the organisation of public transport services. In addition, the author is trying to systematise knowledge on the basic groups of applied innovations, to analyse these innovations in terms of compliance with the definition and models of innovation creation and implementation present in economic sciences.

The author of the monograph is looking for answers to the following questions: Is the introduction of innovations in public transport companies just a public relations activity? Or, on the other side, can we look at the implementation of innovations as a part of long-time strategy and main objectives of the company (organisation)? Are innovations an element of a strategy for the development of the whole organization and its effective management?

This research is conducted in relation to the public transport market, where the service has a social character, with the majority of services being provided by local and state government entities (sometimes services are operated also by commercial, private companies, what gives other interesting science perspective). Thus, naturally arises a plane of potential conflict between the social and public purpose objectives and the management priorities related to the economic purpose. This potential conflict is also an interesting part of the whole research.

The author's considerations focus on a few primary areas. First point is the role of innovation in economic and management science-basing at some theoretical studies. The second important topic is innovation in business management and the whole public transport market. A key area of analysis remains the review of innovations used by public transport companies: both operators and local authorities. The review of innovations includes, inter alia, vehicle autonomy, alternative energy sources, IT systems (supporting different areas of public transport service), organisational innovations and new field of transport. The last chapter of the thesis is devoted to the impact of innovation on the public transport market.

This publication guides the reader through the theory and practice of innovation in public transport-being the first attempt on the Polish market to create a catalogue of innovations applied in public transport organisations.

Keywords: innovations, public transport, urban transport, alternative energy sources, IT systems. 


\section{Doktor Marcin Jurczak}

Pracownik naukowo-dydaktyczny Uniwersytetu Ekonomicznego w Poznaniu, obecnie zatrudniony jako adiunkt w Katedrze Logistyki. Autor i współautor licznych publikacji naukowych i popularno-naukowych z obszaru logistyki i transportu. W swoich zainteresowaniach naukowych i badawczych koncentruje się przede wszystkim na obszarze transportu publicznego, w szczególności komunikacji tramwajowej. Członek Klubu Miłośników Pojazdów Szynowych i Poznańskiej Rady Transportu Aglomeracyjnego.

Problematyka zarówno innowacji, jak i ich roli w rozwijaniu komunikacji publicznej jest bardzo złożona, a wzajemne relacje pomiędzy innowacyjnymi przedsiębiorstwami a transportem publicznym mają niezwykle dynamiczny charakter. Celem niniejszej publikacji jest stworzenie pierwszego, kompleksowego opracowania na temat wykorzystania innowacji w transporcie publicznym: zebranie dostępnej wiedzy na temat innowacji w przedsiębiorstwach komunikacji publicznej, a także innowacji wprowadzanych w organizacji przewozów transportu publicznego.

Książka jest opracowaniem skierowanym do studentów i praktyków zarządzania w sektorze publicznym, a w szczególności organizatorów i operatorów przewozów transportu publicznego. Publikacja ma walory zarówno naukowe, jak i edukacyjne (...). Na uwagę zasługują przedstawione przykłady innowacji w transporcie publicznym, które stanowią niejako katalog innowacji możliwych do wdrożenia w praktyce.

Z recenzji prof. dr hab. Sabiny Kauf

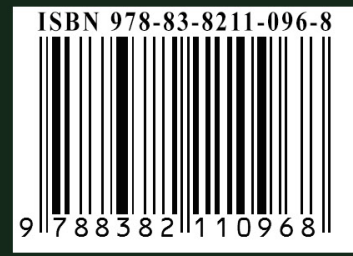

